\title{
Range of Applicability and Bias Determination for Postclosure Criticality of Commercial Spent Nuclear Fuel
}

\section{October 2007}

\author{
Prepared by \\ G. Radulescu, D. E. Mueller, S. Goluoglu, D. F. Hollenbach, and P. B. Fox
}




\title{
DOCUMENT AVAILABILITY
}

Reports produced after January 1,1996, are generally available free via the U.S. Department of Energy (DOE) Information Bridge:

Web site: http://www.osti.gov/bridge

Reports produced before January 1, 1996, may be purchased by members of the public from the following source:

\author{
National Technical Information Service \\ 5285 Port Royal Road \\ Springfield, VA 22161 \\ Telephone: 703-605-6000 (1-800-553-6847) \\ TDD: 703-487-4639 \\ Fax: 703-605-6900 \\ E-mail: info@ntis.fedworld.gov \\ Web site: http://www.ntis.gov/support/ordernowabout.htm
}

Reports are available to DOE employees, DOE contractors, Energy Technology Data Exchange (ETDE) representatives, and International Nuclear Information System (INIS) representatives from the following source:

Office of Scientific and Technical Information

P.O. Box 62

Oak Ridge, TN 37831

Telephone: 865-576-8401

Fax: 865-576-5728

E-mail: reports@adonis.osti.gov

Web site: http://www.osti.gov/contact.html

This report was prepared as an account of work sponsored by an agency of the United States Government. Neither the United States government nor any agency thereof, nor any of their employees, makes any warranty, express or implied, or assumes any legal liability or responsibility for the accuracy, completeness, or usefulness of any information, apparatus, product, or process disclosed, or represents that its use would not infringe privately owned rights. Reference herein to any specific commercial product, process, or service by trade name, trademark, manufacturer, or otherwise, does not necessarily constitute or imply its endorsement, recommendation, or favoring by the United States Government or any agency thereof. The views and opinions of authors expressed herein do not necessarily state or reflect those of the United States Government or any agency thereof. 
ORNL/TM-2007/127

Nuclear Science and Technology Division

\title{
Range of Applicability and Bias Determination for Postclosure Criticality of Commercial Spent Nuclear Fuel
}

\author{
G. Radulescu, D. E. Mueller, S. Goluoglu, D. F. Hollenbach, and P. B. Fox
}

Date Published: October 2007

Prepared by

OAK RIDGE NATIONAL LABORATORY

P.O. Box 2008

Oak Ridge, Tennessee 37831-6283

managed by

UT-BATTELLE, LLC

for the

U.S. DEPARTMENT OF ENERGY

under contract DE-AC05-00OR22725 



\section{CONTENTS}

$\underline{\text { Page }}$

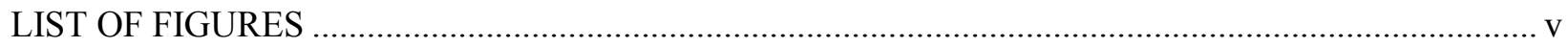

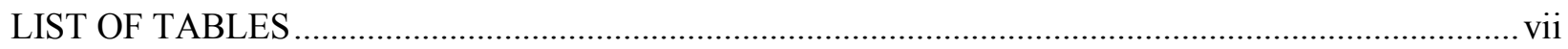

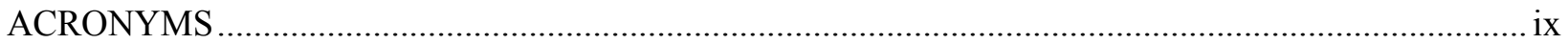

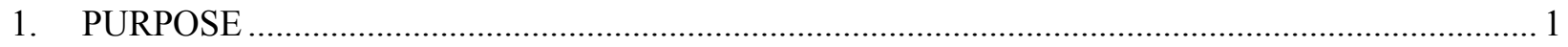

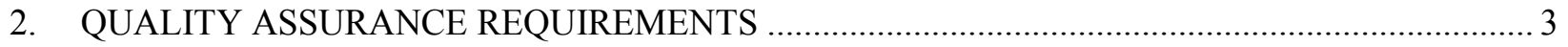

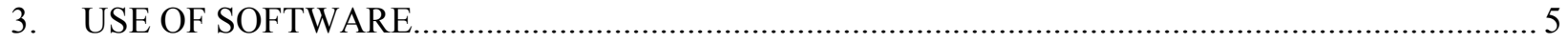

3.1 GENERAL MONTE CARLO N-PARTICLE (MCNP) TRANSPORT CODE ......................... 5

3.2 STANDARDIZED COMPUTER ANALYSIS FOR LICENSING EVALUATION

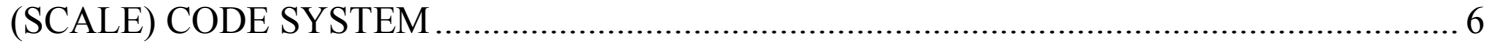

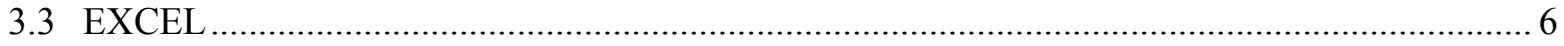

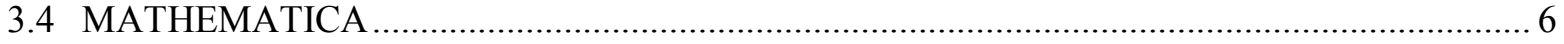

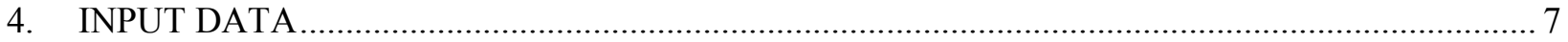

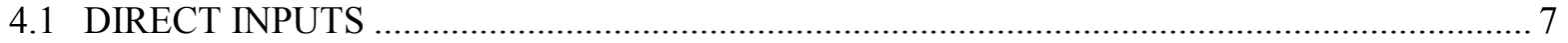

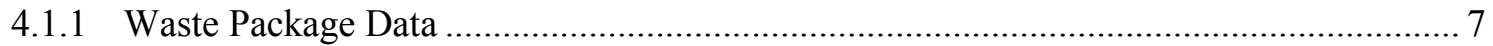

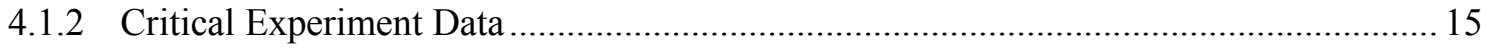

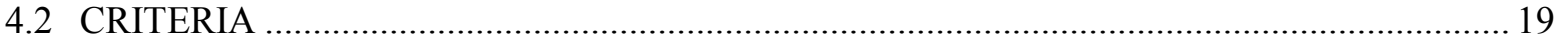

4.3 INDUSTRY STANDARDS AND FEDERAL REGULATIONS …...................................... 19

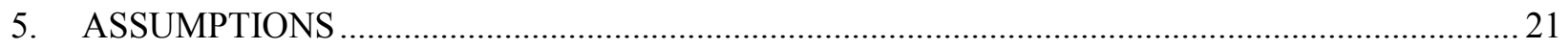

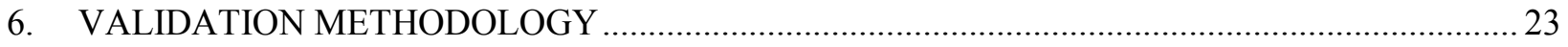

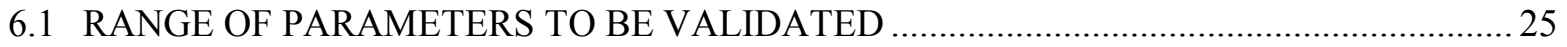

6.2 COMPUTATIONAL TOOLS AND NUCLEAR CROSS-SECTION DATA FOR

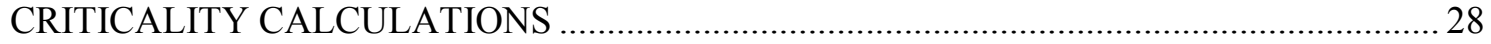

6.3 SELECTION OF CRITICAL EXPERIMENTS FOR CONSIDERATION ............................. 34

6.3.1 Public Laboratory Critical Experiments ...................................................................... 34

6.3.2 Proprietary LCE Data—Haut Taux de Combustion Laboratory Critical Experiments ... 35

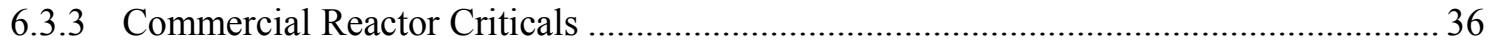

6.4 DETERMINATION OF APPLICABILITY OF CRITICAL EXPERIMENTS ........................ 40

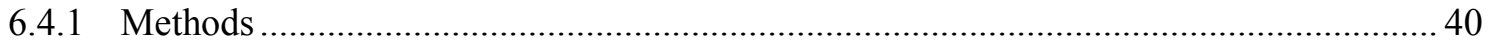

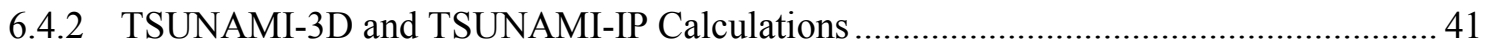

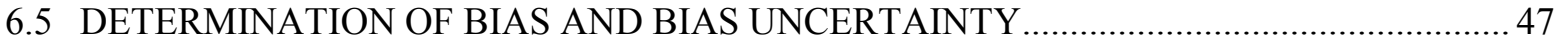

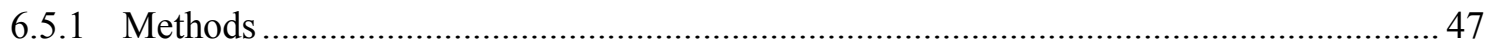

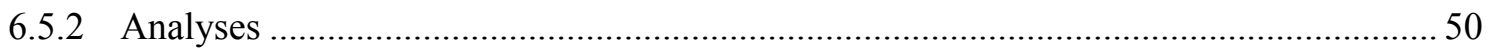

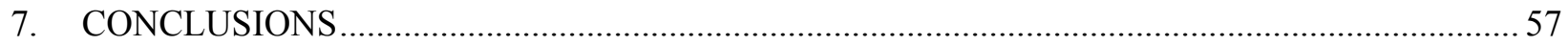

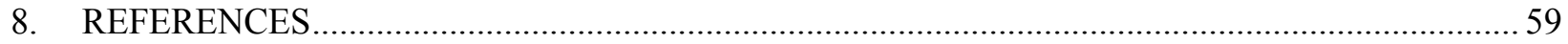




\section{CONTENTS (continued)}

Page

APPENDIX A : Results of Criticality Calculations................................................................................ A-1

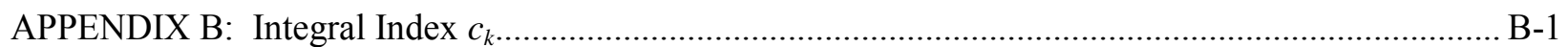

APPENDIX C: Direct Perturbation Calculations …................................................................................ C-1

APPENDIX D: Various CRC Calculations and Results ................................................................. D-1

APPENDIX E: Statistical Methods for LBTL Determination.............................................................. E-1

APPENDIX F: Electronic Data Specifications .......................................................................... 


\section{LIST OF FIGURES}

Figure

Page

$1 \quad$ Fuel pin, guide tube, and instrument tube locations in PWR fuel assembly.............................. 11

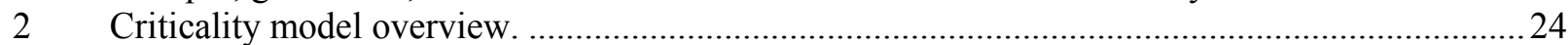

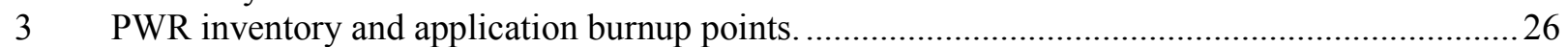

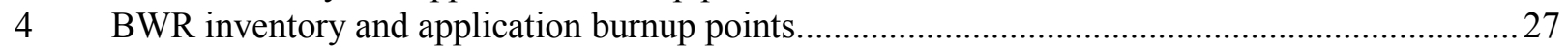

$5 \quad$ Horizontal cross section of the MCNP model for the 21-PWR waste package..............................32

$6 \quad$ Horizontal cross section of the MCNP model for the 44-BWR waste package. .......................... 33

7 Horizontal and partial vertical cross sections of KENO V.a geometry for

a Crystal River Unit 3 state-point. ........................................................................................ 39

$8 \quad c_{k}$ as a function of experiment number: 21-PWR waste package, CSNF of $3 \mathrm{wt} \%{ }^{235} \mathrm{U}$

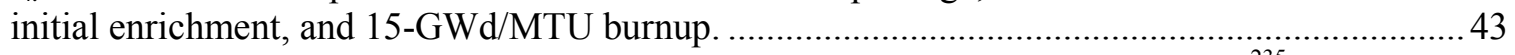

$9 \quad c_{k}$ as a function of experiment number: 21-PWR waste package, CSNF of $5 \mathrm{wt} \%{ }^{235} \mathrm{U}$

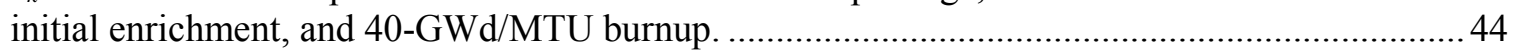

$10 c_{k}$ as a function of experiment number: 21-PWR waste package, fresh fuel

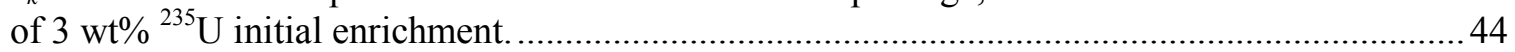

$11 c_{k}$ as a function of experiment number: 44-BWR waste package, CSNF of $3 \mathrm{wt} \%{ }^{235} \mathrm{U}$

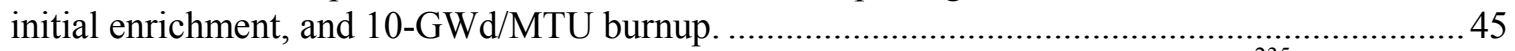

$12 c_{k}$ as a function of experiment number: 44-BWR waste package, CSNF of $5 \mathrm{wt} \%{ }^{235} \mathrm{U}$

initial enrichment, and 30-GWd/MTU burnup.

$13 \quad c_{k}$ as a function of experiment number: 44-BWR waste package, fresh fuel of $3 \mathrm{wt} \%{ }^{235} \mathrm{U}$ initial enrichment.

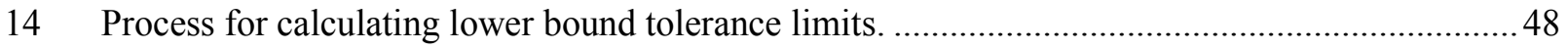

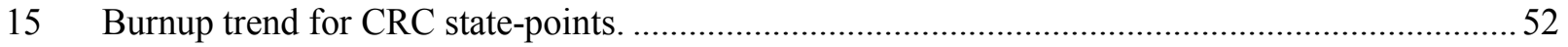

16 EALF trend for HTC LCEs, MOX LCEs, and CRCs............................................................. 53

17 EALF trend for the LEU LCEs applicable to the validation of criticality

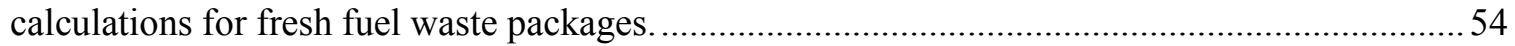

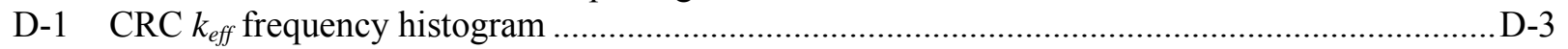





\section{LIST OF TABLES}

Table

Page

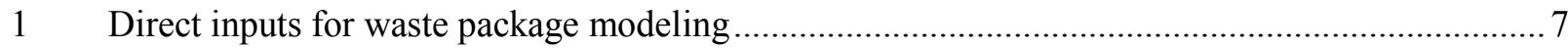

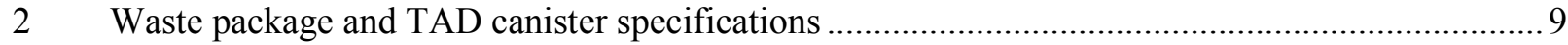

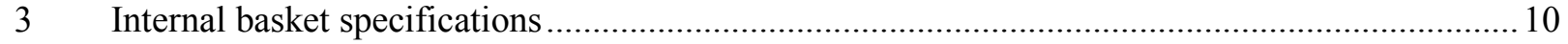

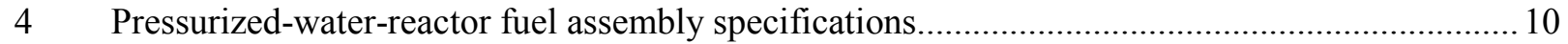

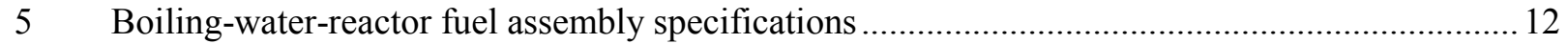

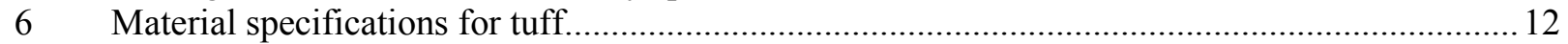

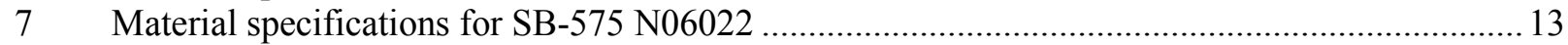

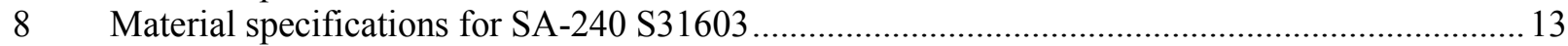

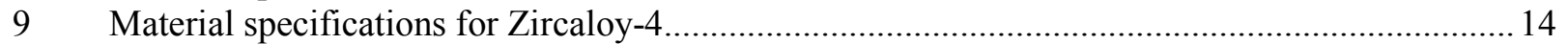

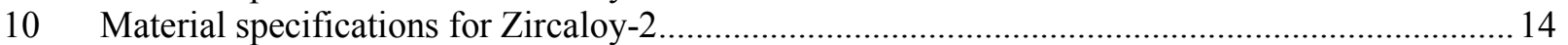

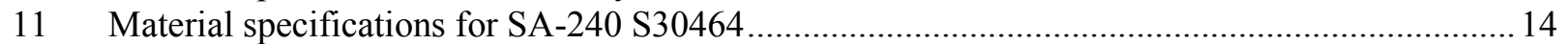

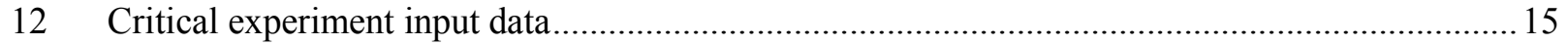

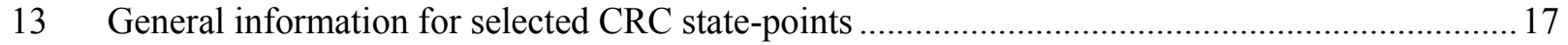

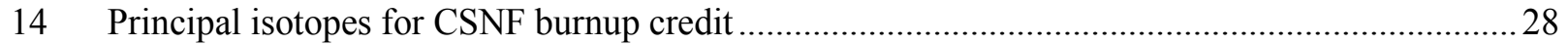

15 Selected MCNP ZAIDs for waste package/TAD material compositions …................................. 30

16 Criticality calculation results for 21-PWR and 44-BWR waste packages ................................. 31

17 Summary of applicable critical experiments to bias and bias uncertainty determination .............. 42

18 LBTL functions from trending with $E A L F, c_{k}$, and burnup using various sets

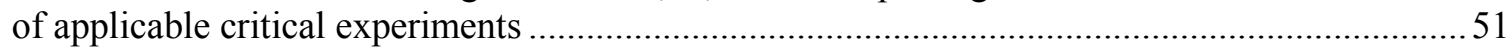

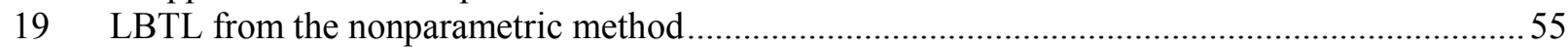

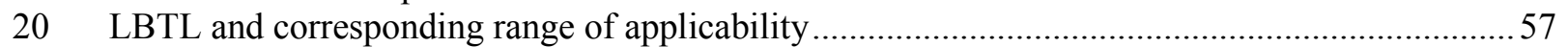

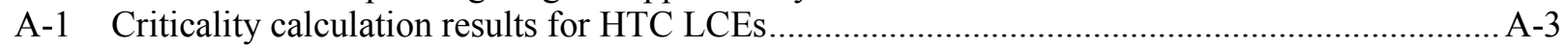

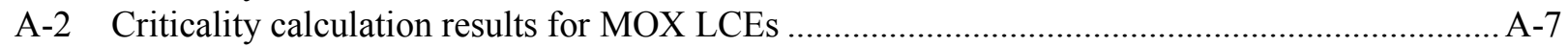

A-3 Criticality calculation results for LEU LCEs .......................................................................

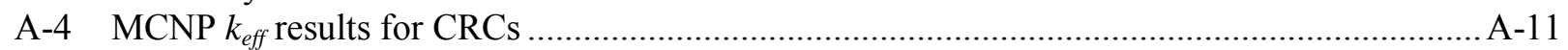

B-1 Integral index $c_{k}$ for nominal 21-PWR waste packages and HTC experiments....................... B-5

B-2 Integral index $c_{k}$ for design-basis 21-PWR waste packages and HTC experiments ................... B-9

B-3 Integral index $c_{k}$ for 44-BWR waste packages and HTC LCEs............................................. B-13

B-4 Integral index $c_{k}$ for nominal 21-PWR waste packages and MOX LCEs............................... B-17

B-5 Integral index $c_{k}$ for design-basis 21-PWR waste packages and MOX LCEs ......................... B-19

B-6 Integral index $c_{k}$ for 44-BWR waste packages and MOX LCEs ........................................ B-21

B-7 Integral index $c_{k}$ for nominal 21-PWR waste packages and LEU LCEs ............................... B-23

B-8 Integral index $c_{k}$ for design-basis 21-PWR waste packages and LEU LCEs........................... B-24

B-9 Integral index $c_{k}$ for 44-BWR waste packages and LEU LCEs ........................................... B-25

B-10 Integral index $c_{k}$ for nominal 21-PWR waste packages and Crystal River CRCs ................... B-26

B-11 Integral index $c_{k}$ for design-basis 21-PWR waste packages and Crystal River CRCs.............. B-27

B-12 Integral index $c_{k}$ for 44-BWR waste packages and Crystal River CRCs................................ B-28

C-1 Comparison of MCNP direct perturbation and TSUNAMI-3D sensitivity calculations ............. C-4

D-1 One-fourth core symmetry MCNP calculations...................................................................... D-3

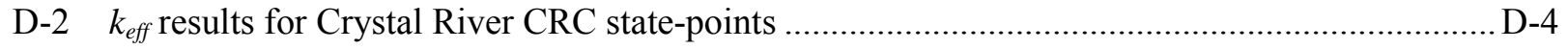

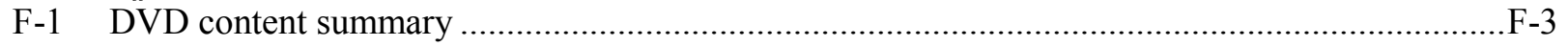





\section{ACRONYMS}

\begin{tabular}{|c|c|}
\hline ASM & American Society of Materials Engineers \\
\hline ASME & American Society of Mechanical Engineers \\
\hline ASTM & American Society of Testing and Materials \\
\hline B\&W & Babcock and Wilcox \\
\hline BSS & borated stainless steel \\
\hline BU & burnup \\
\hline BWR & boiling water reactor \\
\hline CFR & Code of Federal Regulations \\
\hline CL & critical limit \\
\hline CRC & commercial reactor critical \\
\hline CSNF & commercial spent nuclear fuel \\
\hline DFTL & distribution-free tolerance limit \\
\hline DTN & data tracking number \\
\hline DVD & digital video disc \\
\hline EALF & energy of average lethargy of fission \\
\hline EIA & Energy Information Administration \\
\hline ENDF & Evaluated Nuclear Data File \\
\hline FBT & fuel basket tube \\
\hline GE & General Electric \\
\hline HTC & Haut Taux de Combustion \\
\hline IHECSBE & International Handbook of Evaluated Criticality Safety Benchmark Experiments \\
\hline LBTL & lower bound tolerance limit \\
\hline LCE & laboratory critical experiments \\
\hline LEU & low enriched uranium (fuel) \\
\hline LUTB & lower uniform tolerance band \\
\hline MCNP & Monte Carlo N-Particle \\
\hline MOX & mixed oxide (fuel) \\
\hline NDTL & normal distribution tolerance limit \\
\hline NEA & Nuclear Energy Agency \\
\hline NRC & U.S. Nuclear Regulatory Commission \\
\hline NSTD & Nuclear Science and Technology Division \\
\hline OECD & Organization for Economic Co-Operation and Development \\
\hline OCRW & Office of Civilian Radioactive Waste (Management) \\
\hline ORNL & Oak Ridge National Laboratory \\
\hline PWR & pressurized water reactor \\
\hline QARD & Quality Assurance Requirements and Description \\
\hline $\mathrm{S} / \mathrm{U}$ & sensitivity and uncertainty \\
\hline SCALE & Standardized Computer Analysis for Licensing Evaluation \\
\hline SDF & sensitivity data files \\
\hline TAD & transportation, aging, and disposal (canister) \\
\hline USL & upper subcritical limit \\
\hline YMP & Yucca Mountain Project \\
\hline
\end{tabular}





\section{PURPOSE}

The purpose of this calculation report, Range of Applicability and Bias Determination for Postclosure Criticality of Commercial Spent Nuclear Fuel, is to validate the computational method used to perform postclosure criticality calculations. The validation process applies the criticality analysis methodology approach documented in Section 3.5 of the Disposal Criticality Analysis Methodology Topical Report. ${ }^{1}$ The application systems for this validation consist of waste packages containing transport, aging, and disposal canisters (TAD) loaded with commercial spent nuclear fuel (CSNF) of varying assembly types, initial enrichments, and burnup values that are expected from the waste stream and of varying degree of internal component degradation that may occur over the 10,000 -year regulatory time period. ${ }^{2}$ The criticality computational tool being evaluated is the general-purpose Monte Carlo N-Particle (MCNP) ${ }^{3}$ transport code. The nuclear cross-section data distributed with MCNP 5.1.40 and used to model the various physical processes are based primarily on the Evaluated Nuclear Data File/B Version VI (ENDF/B-VI) library. Criticality calculation bias and bias uncertainty and lower bound tolerance limit (LBTL) functions for CSNF waste packages are determined based on the guidance in ANSI/ANS 8.1-1998 (Ref. 4) and ANSI/ANS 8.17-2004 (Ref. 5), as described in Section 3.5.3 of Ref. 1.

The development of this report is consistent with Test Plan for: Range of Applicability and Bias Determination for Postclosure Criticality. ${ }^{6}$ This calculation report has been developed in support of licensing activities for the proposed repository at Yucca Mountain, Nevada, and the results of the calculation may be used in the criticality evaluation for CSNF waste packages based on a conceptual TAD canister. 



\section{QUALITY ASSURANCE REQUIREMENTS}

Development of this report has been determined to be subject to the Yucca Mountain Project quality assurance requirements as described in Test Plan for: Range of Applicability and Bias Determination for Postclosure Criticality. ${ }^{6}$ The Test Plan identifies Oak Ridge National Laboratory (ORNL)-Office of Civilian Radioactive Waste (OCRW) quality assurance procedures applicable to the development, documentation, and electronic management of the data for this report.

The development of the calculation and analysis documentation were performed in accordance with ORNL-OCRW-19.1, Calculation Packages. ${ }^{7}$ The Test Plan for the development of the report was prepared in accordance with ORNL-OCRW-21.0, Scientific Investigations. ${ }^{8}$ The control of electronic data was performed in accordance with ORNL-OCRW-23.0, Control of the Electronic Management of $\operatorname{Data}^{9}$ (refer to Appendix F for the description of electronic management of data). The computer codes used in this calculation have been qualified per ORNL-OCRW-19.0, Software Control. ${ }^{10}$ 



\section{USE OF SOFTWARE}

\subsection{GENERAL MONTE CARLO N-PARTICLE (MCNP) TRANSPORT CODE}

The general-purpose Monte Carlo N-Particle (MCNP) transport code (MCNP 5.1.40.) ${ }^{3}$ was used to calculate the neutron multiplication factors, $k_{\text {eff }}$, for the various cases. The MCNP code used herein has been qualified per ORNL-OCRW-19.0, Software Control. ${ }^{10}$

- Software Title: MCNP

- Version/Revision Number: Version 5/Revision 1.40

- Status/Operating System: Qualified/Compaq Tru64 UNIX, Version 5.1 (Ref. 11) or Linux 2.6.9-42.0.2 ELsmp \#1, x86_64 GNU/Linux (Ref. 12)

- Computer Type: DEC Alpha workstations or CPILE2 Linux cluster of the Nuclear Systems Analysis, Design, and Safety organization, Nuclear Science and Technology Division (NSTD), ORNL

Rationale for Selection: The MCNP computer code employs the Monte Carlo method to perform radiation transport calculations. The Monte Carlo Method stochastically simulates actual physical processes and determines a physical quantity as the expected value of a certain random variable (or combination of several variables). The primary reasons for using this computer code are the following: (1) it is accepted by the U.S. Nuclear Regulatory Commission (NRC) for criticality safety applications; (2) it allows explicit geometrical modeling of material configurations; and (3) it uses continuous-energy cross sections. Additional descriptions of MCNP features and capabilities are provided in Section 6.2.

The input and output files for the MCNP calculations are located in portable digital video discs (DVDs) that are attached to this document, so that an independent repetition of the calculations may be performed.

The MCNP calculations documented in this report had sufficient inactive and active cycles specified on the KCODE card to obtain convergence of both the $k_{\text {eff }}$ and the fission source distribution before starting active cycles for tallies. The values of estimated $k_{\text {eff }}$ standard deviation for all calculations were sufficiently small, that is, less than 0.0005 . However, a few calculations did not pass some of the MCNP statistical checks, including the normality tests for the individual collision, absorption, and track-length $k_{\text {eff }}$ cycle values at the $95 \%$ or $99 \%$ confidence interval. In addition, the MCNP calculations for models containing significantly large numbers of cells with fissionable material, such as the Grand Gulf and McGuire Commercial Reactor Critical (CRC) state-points, did not pass the MCNP test requiring that all cells with fissionable material be sampled and have fission neutron source points. In such cases the results were carefully reviewed, and in some cases additional calculations performed, to ensure that the final results used in this report are reliable. For example, the MCNP $k_{\text {eff }}$ results for Grand Gulf and McGuire state-points are considered adequate for the purpose of this validation for the following reasons. As indicated in the MCNP output files, cells with fissionable material not being sampled may result in smaller $k_{\text {eff }}$ values, which in turn result in lower, that is, conservative, LBTL values. A few calculations were repeated using an increased number of active cycles to obtain results with better statistical behavior. It was noticed that while the statistical behavior improved, the effect on the $k_{\text {eff }}$ value was insignificant. For example, in the case of McGuire state-point 2, the $k_{\text {eff }}$ results obtained with 500 and 2000 active cycles (each with 10,000 source neutrons) are $0.99172 \pm 0.00030$ and $0.99143 \pm 0.00015$, respectively, which shows that better spatial neutron source sampling has an insignificant effect on $k_{\text {eff }}$ (refer to MCNP output files MG2o and MG2so in /DVD/exps/CRC/McGuire/mcnp), provided the statistical error is sufficiently small. 


\subsection{STANDARDIZED COMPUTER ANALYSIS FOR LICENSING EVALUATION (SCALE) CODE SYSTEM}

The Standardized Computer Analysis for Licensing Evaluation (SCALE 5.1) ${ }^{13}$ code system was used to perform various types of calculations by invoking the following code sequences: CSAS $25,{ }^{14}$ TSUNAMI$3 \mathrm{D},{ }^{15}$ and TSUNAMI-IP. ${ }^{16}$ The SCALE code system used herein has been qualified per ORNL-OCRW19.0, Software Control. ${ }^{10}$

- Software Title: SCALE

- Version/Revision Number: Version 5.1

- Status/Operating System: Qualified/Compaq Tru64 UNIX, Version 5.1 (Ref. 17)

- Computer Type: DEC Alpha workstations or CPILE2 Linux cluster of the Nuclear Systems Analysis, Design, and Safety organization, NSTD, ORNL

Rationale for Selection: SCALE is accepted by the NRC for criticality safety applications. This computer code system has multiple unique capabilities relevant to this work including automated sequences to produce problem-dependent multigroup cross-section data, Monte Carlo radiation transport computer codes for criticality calculations (KENO V.a used in this calculation report), and three-dimensional crosssection sensitivity and uncertainty $(\mathrm{S} / \mathrm{U})$ analysis tools for criticality safety applications.

The input and output files for the CSAS25, TSUNAMI-3D, and TSUNAMI-IP calculations are located in portable DVDs that are attached to this document, so that an independent repetition of the calculations may be performed.

The convergence of each of the CSAS25/KENO V.a calculations was assessed for all cases by reviewing the plot of average $k_{\text {eff }}$ by generation run and the plot of average $k_{\text {eff }}$ by generation skipped. No trends were observed in these plots that would be indicative of improper convergence. In addition, the frequency distribution plots were examined. These frequency distribution plots show single $k_{\text {eff }}$ peaks, which is also an indication of convergence. The $k_{\text {eff }}$ results of KENO V.a forward and adjoint calculations, which are used in the S/U (TSUNAMI-3D) analysis, were adequately similar.

\subsection{EXCEL}

The commercial off-the shelf software Microsoft Office Excel 2003 (copyright Microsoft Corporation) was used in calculations to manipulate the inputs, and tabulate and chart results using standard mathematical expressions and operations. It was also used to implement the statistical methods for LBTL calculations that are described in References 18 (Appendix C), 19, and 20. Microsoft Excel was used only as a worksheet and not as a software routine. Therefore, Excel is exempt from the requirements of ORNLOCRW-19.0, Software Control. ${ }^{10}$ All necessary information for reproducing the operations performed is provided in Section 6.5.1 and the spreadsheets (on the DVD attachment), as indicated in Section 6.5.2, so that an independent repetition of the operations can be performed.

\subsection{MATHEMATICA}

The commercial off-the shelf software Mathematica 5.2.0.0 (copyright Wolfgram Research, Inc.) was used to determine the $D$ parameter in Eq. E-1 (see Appendix E). All necessary information for reproducing the operations performed is provided in the DVD attachment (/DVD/cl/D-search-numeric.nb) so that an independent repetition of the operations can be performed. Mathematica was used in its native form and therefore, it is exempt from the requirements of ORNL-OCRW-19.0, Software Control. ${ }^{10}$ 


\section{INPUT DATA}

\subsection{DIRECT INPUTS}

Direct inputs to the analysis include dimensional and material specifications for the waste package and the critical experiments, as detailed in the following sections.

\subsubsection{Waste Package Data}

The following data were used as direct inputs to the analyses described in Section 6. Table 1 lists direct inputs, their sources, and the justification for use as direct inputs. Technical input data includes Yucca Mountain Project (YMP) qualified data listed by data tracking number (DTN), American Society of Mechanical Engineers (ASME) specifications, American Society of Testing and Materials (ASTM) and American Society of Materials Engineers (ASM) consensus data, technical products developed in accordance with Quality Assurance Requirements and Description (QARD), ${ }^{21}$ industry handbooks, ${ }^{22,23}$ and NRC- and industry-approved documents. The technical inputs were used to create MCNP and SCALE (CSAS25 and TSUNAMI-3D) input files for the waste packages containing TAD canisters loaded with either pressurized-water-reactor (PWR) or boiling-water-reactor (BWR) spent fuel assemblies.

Table 1. Direct inputs for waste package modeling

\begin{tabular}{|c|c|c|c|}
\hline Parameter & Value & Source & Justification \\
\hline $\begin{array}{l}\text { Waste package and } \\
\text { TAD canister } \\
\text { specifications }\end{array}$ & See Table 2 & $\begin{array}{l}\text { Ref. 24, Section } 4 \text { and } \\
\text { Appendix A. }\end{array}$ & $\begin{array}{l}\text { Approved technical product developed in } \\
\text { accordance with QARD requirements }\end{array}$ \\
\hline $\begin{array}{l}\text { TAD internal basket } \\
\text { specifications }\end{array}$ & See Table 3 & Ref. 25. & $\begin{array}{l}\text { Approved NRC design for spent nuclear fuel } \\
\text { storage }\end{array}$ \\
\hline $\begin{array}{l}\text { Minimum } \\
\text { recommended } \\
\text { absorber plate } \\
\text { thickness }\end{array}$ & $6 \mathrm{~mm}$ & Ref. 26. & $\begin{array}{l}\text { Approved technical product developed in } \\
\text { accordance with QARD requirements }\end{array}$ \\
\hline $\begin{array}{l}\text { PWR fuel assembly } \\
\text { specifications }\end{array}$ & $\begin{array}{l}\text { See Table } 4 \text { and } \\
\text { Fig. } 1\end{array}$ & Ref. 27. & $\begin{array}{l}\text { Approved technical product developed in } \\
\text { accordance with QARD requirements }\end{array}$ \\
\hline $\begin{array}{l}\text { BWR fuel assembly } \\
\text { specifications }\end{array}$ & See Table 5 & Ref. 28. & $\begin{array}{l}\text { Considered established fact data because they } \\
\text { are from a report from the Electric Power } \\
\text { Research Institute that is accepted by the } \\
\text { scientific and engineering community }\end{array}$ \\
\hline $\begin{array}{l}\text { BWR fuel assembly } \\
\text { channel dimensions }\end{array}$ & See Table 5 & Ref. 29. & $\begin{array}{l}\text { Approved technical product developed in } \\
\text { accordance with QARD requirements }\end{array}$ \\
\hline $\begin{array}{l}\text { BWR TAD fuel } \\
\text { basket tube (FBT) } \\
\text { thickness }\end{array}$ & $\begin{array}{l}4.7625 \mathrm{~mm} \\
(3 / 16 \mathrm{in} .)\end{array}$ & Ref. 30. & $\begin{array}{l}\text { Representative of minimum thickness for BWR } \\
\text { basket from approved technical product } \\
\text { developed in accordance with QARD } \\
\text { requirements }\end{array}$ \\
\hline Composition of tuff & See Table 6 & $\begin{array}{l}\text { DTN: } \\
\text { GS000308313211.001, } \\
\text { Table S00224 } 001, \\
\text { mean values. }{ }^{3 \top}{ }^{2}\end{array}$ & YMP qualified data \\
\hline
\end{tabular}


Table 1. Direct inputs for waste package modeling (continued)

\begin{tabular}{|c|c|c|c|}
\hline Density of tuff & $\begin{array}{l}\text { Average of three } \\
\text { hydrogeologic units; see } \\
\text { Table } 6\end{array}$ & $\begin{array}{l}\text { DTN: MO0109HYMXP } \\
\text { ROP.001, Table } \\
\text { S01144_001 (rows 1333, } \\
\text { 1345, and } 1739 \text { for } \\
\text { samples tpt pmn, pll, and } \\
\text { pln). }\end{array}$ & YMP qualified data \\
\hline $\begin{array}{l}\text { Density for SA-240 } \\
\text { S30464 neutron } \\
\text { absorber plate }\end{array}$ & $7.8 \mathrm{~g} / \mathrm{cm}^{3}\left(0.282 \mathrm{lb} / \mathrm{in}^{3}\right)$ & Ref. 24, Appendix A. & $\begin{array}{l}\text { Approved technical product developed } \\
\text { in accordance with QARD } \\
\text { requirements }\end{array}$ \\
\hline $\begin{array}{l}\text { Material } \\
\text { specifications for } \\
\text { SB-575 N06022 }\end{array}$ & See Table 7 & $\begin{array}{l}\text { DTN: MO0003RIB0007 } \\
\text { 1.001, Table } \\
\text { S04196 001. }\end{array}$ & YMP qualified data \\
\hline $\begin{array}{l}\text { Material } \\
\text { specifications for } \\
\text { SA-240 S31603 }\end{array}$ & See Table 8 & $\begin{array}{l}\text { ASME 2001, Section II, } \\
\text { SA-240, Table } 1 .{ }^{34}\end{array}$ & $\begin{array}{l}\text { Considered established fact data } \\
\text { because this is code from a } \\
\text { professional society (ASME) }\end{array}$ \\
\hline $\begin{array}{l}\text { Material density for } \\
\text { SA-240 S31603 }\end{array}$ & $7.98 \mathrm{~g} / \mathrm{cm}^{3}$ & $\begin{array}{l}\text { ASTM G 1-90 1999, p. 7, } \\
\text { Table X1. }\end{array}$ & $\begin{array}{l}\text { Considered established fact datum } \\
\text { because this is a consensus standard } \\
\text { from ASTM }\end{array}$ \\
\hline $\begin{array}{l}\text { Material } \\
\text { specifications for } \\
\text { Zircaloy-4 }\end{array}$ & See Table 9 & $\begin{array}{l}\text { ASTM B 811-97 2000, } \\
\text { p. 2, Table 2. }{ }^{36}\end{array}$ & $\begin{array}{l}\text { Considered established fact data } \\
\text { because this is a consensus standard } \\
\text { from ASTM }\end{array}$ \\
\hline $\begin{array}{l}\text { Material density for } \\
\text { Zircaloy-4 }\end{array}$ & $6.56 \mathrm{~g} / \mathrm{cm}^{3}$ & $\begin{array}{l}\text { ASM International } 1990 \text {, } \\
\text { p. } 666 \text {, Table } 6 .^{37}\end{array}$ & $\begin{array}{l}\text { Considered established fact datum } \\
\text { because this is a consensus standard } \\
\text { from ASM }\end{array}$ \\
\hline $\begin{array}{l}\text { Material } \\
\text { specifications for } \\
\text { Zircaloy-2 }\end{array}$ & See Table 10 & $\begin{array}{l}\text { ASTM B 811-97 2000, } \\
\text { Table 2. }\end{array}$ & $\begin{array}{l}\text { Considered established fact data } \\
\text { because this is a consensus standard } \\
\text { from ASTM }\end{array}$ \\
\hline $\begin{array}{l}\text { Material density for } \\
\text { Zircaloy-2 }\end{array}$ & $6.55 \mathrm{~g} / \mathrm{cm}^{3}$ & $\begin{array}{l}\text { ASM International } \\
1967 . .^{.8}\end{array}$ & $\begin{array}{l}\text { Considered established fact datum } \\
\text { because this is a consensus standard } \\
\text { from ASM }\end{array}$ \\
\hline $\begin{array}{l}\text { Material } \\
\text { specifications for } \\
\text { SA-240 S30464 }\end{array}$ & See Table 11 & $\begin{array}{l}\text { ASTM A 887-89 2004, } \\
\text { Table } 1 .{ }^{39}\end{array}$ & $\begin{array}{l}\text { Considered established fact data } \\
\text { because this is a consensus standard } \\
\text { from ASTM }\end{array}$ \\
\hline $\begin{array}{l}\text { PWR spent fuel } \\
\text { isotopic compositions }\end{array}$ & $\begin{array}{l}\text { Output, spreadsheet } \\
\text { LoadingCurve_v344.xls, } \\
\text { worksheet FuelIsotopics }\end{array}$ & Ref. 40. & $\begin{array}{l}\text { Approved technical product developed } \\
\text { in accordance with QARD } \\
\text { requirements }\end{array}$ \\
\hline $\begin{array}{l}\text { BWR spent fuel } \\
\text { isotopic compositions }\end{array}$ & $\begin{array}{l}\text { Output, spreadsheet } \\
\text { LoadingCurve_v344.xls, } \\
\text { worksheet FuelIsotopics }\end{array}$ & Ref. 41. & $\begin{array}{l}\text { Qualified supplier approved technical } \\
\text { product developed in accordance with } \\
\text { QARD requirements }\end{array}$ \\
\hline $\begin{array}{l}\text { Axial zone weighting } \\
\text { factors }\end{array}$ & $\begin{array}{l}\text { Output, spreadsheet } \\
\text { LoadingCurve_v344.xls, } \\
\text { worksheet FuelIsotopics }\end{array}$ & Ref. 42. & $\begin{array}{l}\text { Approved technical product developed } \\
\text { in accordance with QARD } \\
\text { requirements }\end{array}$ \\
\hline
\end{tabular}


Table 2. Waste package and TAD canister specifications

\begin{tabular}{|c|c|c|c|}
\hline Component & Material & Parameter & Dimension (mm) \\
\hline \multirow{5}{*}{$\begin{array}{l}\text { Waste Package } \\
\text { Outer Barrier }\end{array}$} & \multirow{5}{*}{$\begin{array}{l}\text { SB-575 N06022 } \\
\text { (Alloy 22) }\end{array}$} & Outer diameter & $1,881.60$ (74.08 in.) \\
\hline & & Thickness & 25.40 (1.00 in.) \\
\hline & & Inner diameter & $1,830.80$ (calculated) \\
\hline & & Total length & $5,691.38$ (224.07 in.) \\
\hline & & Thickness of bottom & 25.40 (1.00 in.) \\
\hline \multirow{5}{*}{$\begin{array}{l}\text { Waste Package } \\
\text { Inner Vessel }\end{array}$} & \multirow{5}{*}{$\begin{array}{l}\text { SA-240 S31600 } \\
\text { (Stainless Steel Type 316) }\end{array}$} & Outer diameter & $1,821.20$ (71.70 in.) \\
\hline & & Thickness & 50.80 \\
\hline & & Inner diameter & 1,719.6 (calculated) \\
\hline & & Total length & $5,499.1$ \\
\hline & & Thickness of bottom & 50.8 (2 in.) \\
\hline \multirow[t]{5}{*}{ TAD Canister } & \multirow{5}{*}{$\begin{array}{l}\text { SA-240 S31603 } \\
\text { (Stainless Steel Type 316L) }\end{array}$} & Outer diameter & 1,689.1 (66.5 in.) \\
\hline & & Thickness & 25.4 (1.00 in.) \\
\hline & & Inner diameter & $1,638.3$ (calculated) \\
\hline & & Total length & 5,384.8 (212.0 in.) \\
\hline & & Thickness of bottom & 88.9 (3.5 in.) \\
\hline TAD Canister Shield Plug & $\begin{array}{l}\text { SA-240 S31603 } \\
\text { (Stainless Steel Type 316L) }\end{array}$ & Thickness & 381 (15.0 in.) \\
\hline
\end{tabular}

Source: Ref. 24, Section 4 and Appendix A.

${ }^{a}$ Represented as SA-240 S31603 in MCNP representations. This is considered to have a negligible impact (change in $k_{\text {eff }}$ is within the statistical uncertainty) on the results since the waste package inner vessel acts as a secondary reflector. 
Table 3. Internal basket specifications

\begin{tabular}{|c|c|c|c|}
\hline Component & Material & Parameter & Dimension (mm) \\
\hline \multirow{3}{*}{$\begin{array}{l}\text { PWR Fuel } \\
\text { Basket } \\
\text { Tube }\end{array}$} & \multirow{3}{*}{$\begin{array}{l}\text { SA-240 S31603 } \\
\text { (Stainless Steel 316L) }\end{array}$} & Internal distance across flats & $220.726(8.69 \text { in. })^{a}$ \\
\hline & & Thickness & 7.9375 (5/16 in.) \\
\hline & & Length & $4889.5(192.5 \text { in. })^{b}$ \\
\hline \multirow{3}{*}{$\begin{array}{l}\text { PWR-Fuel } \\
\text { Neutron } \\
\text { Absorber } \\
\text { Plate } \\
\end{array}$} & \multirow{3}{*}{$\begin{array}{l}\text { SA-240 S30464 } \\
\text { (Borated Stainless } \\
\text { Steel) }\end{array}$} & Thickness & 11.1125 (nominal) \\
\hline & & Width & $190.5(7.50 \text { in. })^{a}$ \\
\hline & & Length & $4889.5^{c}$ \\
\hline \multirow{3}{*}{$\begin{array}{l}\text { BWR Fuel } \\
\text { Basket } \\
\text { Tube }\end{array}$} & \multirow{3}{*}{$\begin{array}{l}\text { SA-240 S31603 } \\
\text { (Stainless Steel 316L) }\end{array}$} & Internal distance across flats & $152.2222(5.993 \text { in. })^{a}$ \\
\hline & & Thickness & $4.7625(3 / 16 \text { in. })^{c}$ \\
\hline & & Length & $4889.5(192.5 \text { in. })^{b}$ \\
\hline \multirow{3}{*}{$\begin{array}{l}\text { BWR-fuel } \\
\text { Neutron } \\
\text { Absorber } \\
\text { Plate }\end{array}$} & \multirow{3}{*}{$\begin{array}{l}\text { SA-240 S30464 } \\
\text { (Borated Stainless } \\
\text { Steel) }\end{array}$} & Thickness & 11.1125 (nominal) \\
\hline & & Width & $120.65(4.75 \text { in. })^{a}$ \\
\hline & & Length & $4889.5^{d}$ \\
\hline
\end{tabular}

${ }^{a}$ Ref. 25, Figures 6.3.2 and 6.3.3.

${ }^{b}$ Derived based on total TAD canister length and having 1-in. clearance between top of basket and lid to allow for thermal expansion.

${ }^{c}$ Value taken from Ref. 30, Table 21.

${ }^{d}$ Same length as FBT.

Table 4. Pressurized-water-reactor fuel assembly specifications

\begin{tabular}{|l|l|}
\hline \multicolumn{1}{|c|}{ Assembly component } & \multicolumn{1}{c|}{ Specification } \\
\hline Lattice & $15 \times 15$ \\
\hline Fuel pellet (outer diameter) & $0.93980 \mathrm{~cm}$ \\
\hline Fuel rod cladding (inner diameter) & $0.95758 \mathrm{~cm}$ \\
\hline Fuel rod cladding (outer diameter) & $1.09220 \mathrm{~cm}$ \\
\hline Active fuel length & $360.172 \mathrm{~cm}$ \\
\hline Pin pitch & $1.44272 \mathrm{~cm}$ \\
\hline Guide tube (inner diameter) & $1.26492 \mathrm{~cm}$ \\
\hline Guide tube (outer diameter) & $1.34620 \mathrm{~cm}$ \\
\hline Instrument tube (inner diameter) & $1.12014 \mathrm{~cm}$ \\
\hline Instrument tube (outer diameter) & $1.38193 \mathrm{~cm}$ \\
\hline $\begin{array}{l}\text { Fuel clad, guide tube, and instrument } \\
\text { tube material }\end{array}$ & Zircaloy-4 \\
\hline Fuel density & \\
\hline
\end{tabular}

Source: Ref. 27, pp. 2-5.

${ }^{a}$ Calculated based on $98 \%$ theoretical density value of $10.96 \mathrm{~g} / \mathrm{cm}^{3}$ for $\mathrm{UO}_{2}$ (Ref. 43). 


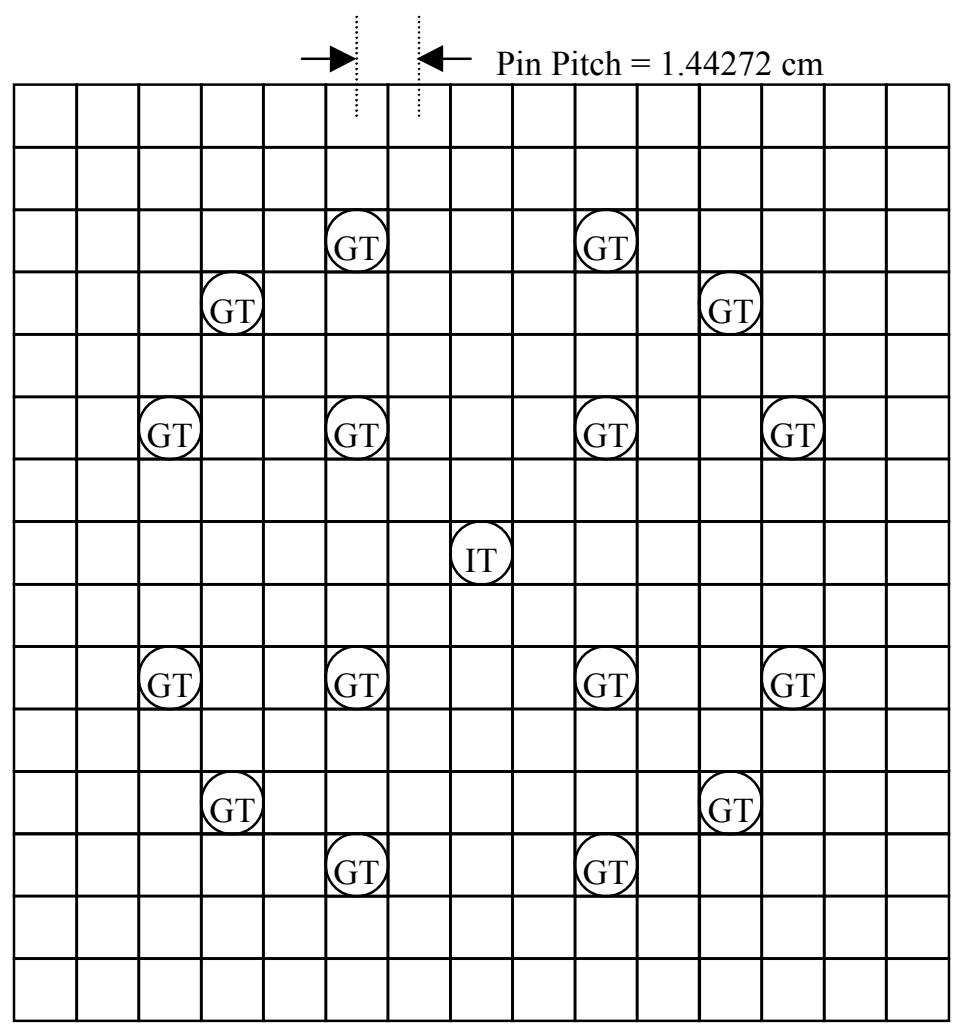

GT Guide Tube IT Instrument Tube $\square$ Fuel Pin

This sketch is not to scale.

Fig. 1. Fuel pin, guide tube, and instrument tube locations in PWR fuel assembly. 
Table 5. Boiling-water-reactor fuel assembly specifications

\begin{tabular}{|l|l|}
\hline \multicolumn{1}{|c|}{ Assembly component } & \multicolumn{1}{c|}{ Specification $^{a}$} \\
\hline Lattice & $7 \times 7$ \\
\hline Fuel pellet (outer diameter) ${ }^{b}$ & $1.23952 \mathrm{~cm}(0.488$ in.) \\
\hline Fuel rod cladding (thickness) & $0.08128 \mathrm{~cm}(0.032$ in.) \\
\hline Fuel rod cladding (inner diameter) & $1.26746 \mathrm{~cm}$ \\
\hline Fuel rod cladding (outer diameter) & $1.43002 \mathrm{~cm}(0.563$ in.) \\
\hline Active fuel (length) & $365.76 \mathrm{~cm}(144$ in.) \\
\hline Clad material & Zircaloy- 2 \\
\hline Channel material & Zircaloy-4 \\
\hline Pin pitch & $1.87452 \mathrm{~cm}(0.738$ in.) \\
\hline Channel (inner width) ${ }^{c}$ & $13.246 \mathrm{~cm}$ \\
\hline Channel (thickness) ${ }^{c}$ & $0.3048 \mathrm{~cm}$ \\
\hline Fuel density $^{d}$ & $10.741 \mathrm{~g} / \mathrm{cm}^{3}$ \\
\hline
\end{tabular}

Source: Ref. 28, pp. A-1 to A-3.

${ }^{a}$ Values in parentheses are from the source reference.

${ }^{b}$ The representations use a smeared pellet density over the inner clad diameter.

${ }^{c}$ Channel dimensions were taken from Ref. 29, Table 2-1.

${ }^{d}$ Calculated based on $98 \%$ theoretical density value of $10.96 \mathrm{~g} / \mathrm{cm}^{3}$ for $\mathrm{UO}_{2}$ (Ref. 44).

Table 6. Material specifications for tuff

\begin{tabular}{|l|l|l|l|}
\hline Mineral & wt $^{\boldsymbol{a}}$ & Mineral & wt ${ }^{\boldsymbol{a}}$ \\
\hline $\mathrm{SiO}_{2}$ & 76.29 & $\mathrm{Na}_{2} \mathrm{O}$ & 3.52 \\
\hline $\mathrm{Al}_{2} \mathrm{O}_{3}$ & 12.55 & $\mathrm{~K}_{2} \mathrm{O}$ & 4.83 \\
\hline $\mathrm{FeO}$ & 0.14 & $\mathrm{TiO}_{2}$ & 0.11 \\
\hline $\mathrm{Fe}_{2} \mathrm{O}_{3}$ & 0.97 & $\mathrm{P}_{2} \mathrm{O}_{5}$ & 0.05 \\
\hline $\mathrm{MgO}$ & 0.13 & $\mathrm{MnO}$ & 0.07 \\
\hline $\mathrm{CaO}$ & 0.5 & Density & \\
\hline
\end{tabular}

Source: Refs. 31 and 32.

${ }^{a}$ DTN: GS000308313211.001, Table S00224_001, mean values.

${ }^{b}$ Average of three hydrogeologic units for tptpmn, tptpll, and tptpln (rows 1333, 1345, and 1739) of DTN: MO0109HYMXPROP.001, Table S01144_001.

Note: The iron elemental weight percents were expanded into their constituent natural isotopic weights percents for use in MCNP and SCALE calculations (refer to Section 6.2 for the set of MCNP data tables being validated). 
Table 7. Material specifications for SB-575 N06022

\begin{tabular}{|l|l|l|l|l|l|}
\hline $\begin{array}{c}\text { Element/ } \\
\text { isotope }\end{array}$ & ZAID $^{a}$ & wt \% & $\begin{array}{c}\text { Element/ } \\
\text { isotope }\end{array}$ & ZAID $^{a}$ & wt \% \\
\hline C-nat & $6000.66 \mathrm{c}$ & 0.0150 & ${ }^{59} \mathrm{Co}$ & $27059.66 \mathrm{c}$ & 2.5000 \\
\hline${ }^{55} \mathrm{Mn}$ & $25055.62 \mathrm{c}$ & 0.5000 & ${ }^{182} \mathrm{~W}^{b}$ & $74182.62 \mathrm{c}$ & 0.7877 \\
\hline $\mathrm{Si}-$ nat & $14000.60 \mathrm{c}$ & 0.0800 & ${ }^{183} \mathrm{~W}^{b}$ & $74183.62 \mathrm{c}$ & 0.4278 \\
\hline${ }^{50} \mathrm{Cr}$ & $24050.62 \mathrm{c}$ & 0.8879 & ${ }^{184} \mathrm{~W}^{b}$ & $74184.62 \mathrm{c}$ & 0.9209 \\
\hline${ }^{52} \mathrm{Cr}$ & $24052.62 \mathrm{c}$ & 17.7863 & ${ }^{186} \mathrm{~W}^{b}$ & $74186.62 \mathrm{c}$ & 0.8636 \\
\hline${ }^{53} \mathrm{Cr}$ & $24053.62 \mathrm{c}$ & 2.0554 & $\mathrm{~V}$ & $23000.62 \mathrm{c}$ & 0.3500 \\
\hline${ }^{54} \mathrm{Cr}$ & $24054.62 \mathrm{c}$ & 0.5202 & ${ }^{54} \mathrm{Fe}$ & $26054.62 \mathrm{c}$ & 0.2260 \\
\hline${ }^{58} \mathrm{Ni}$ & $28058.62 \mathrm{c}$ & 36.8024 & ${ }^{56} \mathrm{Fe}$ & $26056.62 \mathrm{c}$ & 3.6759 \\
\hline${ }^{60} \mathrm{Ni}$ & $28060.62 \mathrm{c}$ & 14.6621 & ${ }^{57} \mathrm{Fe}$ & $26057.62 \mathrm{c}$ & 0.0865 \\
\hline${ }^{61} \mathrm{Ni}$ & $28061.62 \mathrm{c}$ & 0.6481 & ${ }^{58} \mathrm{Fe}$ & $26058.62 \mathrm{c}$ & 0.0116 \\
\hline${ }^{62} \mathrm{Ni}$ & $28062.62 \mathrm{c}$ & 2.0975 & ${ }^{32} \mathrm{~S}$ & $16032.62 \mathrm{c}$ & 0.0200 \\
\hline${ }^{64} \mathrm{Ni}$ & $28064.62 \mathrm{c}$ & 0.5547 & ${ }^{31} \mathrm{P}$ & $15031.66 \mathrm{c}$ & 0.0200 \\
\hline $\mathrm{Mo}-\mathrm{nat}$ & $42000.66 \mathrm{c}$ & 13.5000 & $\mathrm{Density}=8.69 \mathrm{~g} / \mathrm{cm}^{3}$ & \\
\hline
\end{tabular}

Source: Ref. 33, DTN: MO0003RIB00071.000, Table S04196_001.

${ }^{a}$ ZAID = MCNP data table identifier (refer to Section 6.2).

${ }^{b} \mathrm{~W}-180$ cross-sectional libraries are not available, so the atom percents of the remaining $\mathrm{W}$ isotopes were used to renormalize the elemental weight and derive isotopic weight percents, excluding the negligible 0.120 atom percent of $\mathrm{W}-180$ in natural $\mathrm{W}$.

Table 8. Material specifications for SA-240 S31603

\begin{tabular}{|l|c|c|c|c|c|}
\hline $\begin{array}{c}\text { Element/ } \\
\text { isotope }\end{array}$ & ZAID $^{\boldsymbol{a}}$ & wt \% & $\begin{array}{c}\text { Element/ } \\
\text { isotope }\end{array}$ & ZAID $^{\boldsymbol{a}}$ & wt \% \\
\hline $\mathrm{C}-$ nat & $6000.66 \mathrm{c}$ & 0.0300 & ${ }^{54} \mathrm{Fe}$ & $26054.62 \mathrm{c}$ & 3.7036 \\
\hline${ }^{14} \mathrm{~N}$ & $7014.62 \mathrm{c}$ & 0.1000 & ${ }^{56} \mathrm{Fe}$ & $26056.62 \mathrm{c}$ & 60.2343 \\
\hline $\mathrm{Si}-$ nat & $14000.60 \mathrm{c}$ & 0.7500 & ${ }^{57} \mathrm{Fe}$ & $26057.62 \mathrm{c}$ & 1.4167 \\
\hline${ }^{31} \mathrm{P}$ & $15031.66 \mathrm{c}$ & 0.0450 & ${ }^{58} \mathrm{Fe}$ & $26058.62 \mathrm{c}$ & 0.1904 \\
\hline${ }^{32} \mathrm{~S}$ & $16032.62 \mathrm{c}$ & 0.0300 & ${ }^{58} \mathrm{Ni}$ & $28058.62 \mathrm{c}$ & 8.0641 \\
\hline${ }^{50} \mathrm{Cr}$ & $24050.62 \mathrm{c}$ & 0.7103 & ${ }^{60} \mathrm{Ni}$ & $28060.62 \mathrm{c}$ & 3.2127 \\
\hline${ }^{52} \mathrm{Cr}$ & $24052.62 \mathrm{c}$ & 14.2291 & ${ }^{61} \mathrm{Ni}$ & $28061.62 \mathrm{c}$ & 0.1420 \\
\hline${ }^{53} \mathrm{Cr}$ & $24053.62 \mathrm{c}$ & 1.6443 & ${ }^{62} \mathrm{Ni}$ & $28062.62 \mathrm{c}$ & 0.4596 \\
\hline${ }^{54} \mathrm{Cr}$ & $24054.62 \mathrm{c}$ & 0.4162 & ${ }^{64} \mathrm{Ni}$ & $28064.62 \mathrm{c}$ & 0.1216 \\
\hline $\mathrm{Mn}-55$ & $25055.62 \mathrm{c}$ & 2.0000 & $\mathrm{Mo}-\mathrm{nat}$ & $42000.66 \mathrm{c}$ & 2.5000 \\
\hline \multicolumn{7}{|c|}{ Density $=7.98 \mathrm{~g} / \mathrm{cm}^{3}$} \\
\hline
\end{tabular}

Source: Refs. 34 and 35.

${ }^{a}$ ZAID = MCNP data table identifier (refer to Section 6.2). 
Table 9. Material specifications for Zircaloy-4

\begin{tabular}{|l|c|c|c|c|c|}
\hline $\begin{array}{c}\text { Element/ } \\
\text { isotope }\end{array}$ & ZAID $^{\boldsymbol{a}}$ & wt \% & $\begin{array}{c}\text { Element/ } \\
\text { isotope }\end{array}$ & \multicolumn{1}{c|}{ ZAID $^{\boldsymbol{a}}$} & wt \% \\
\hline${ }^{50} \mathrm{Cr}$ & $24050.62 \mathrm{c}$ & 0.0042 & ${ }^{57} \mathrm{Fe}$ & $26057.62 \mathrm{c}$ & 0.0045 \\
\hline${ }^{52} \mathrm{Cr}$ & $24052.62 \mathrm{c}$ & 0.0837 & ${ }^{58} \mathrm{Fe}$ & $26058.62 \mathrm{c}$ & 0.0006 \\
\hline${ }^{53} \mathrm{Cr}$ & $24053.62 \mathrm{c}$ & 0.0097 & ${ }^{16} \mathrm{O}$ & $8016.62 \mathrm{c}$ & 0.1250 \\
\hline${ }^{54} \mathrm{Cr}$ & $24054.62 \mathrm{c}$ & 0.0024 & Zr-nat & $40000.66 \mathrm{c}$ & 98.1150 \\
\hline${ }^{54} \mathrm{Fe}$ & $26054.62 \mathrm{c}$ & 0.0119 & Sn-nat & $50000.42 \mathrm{c}$ & 1.4500 \\
\hline${ }^{56} \mathrm{Fe}$ & $26056.62 \mathrm{c}$ & 0.1930 & Density $=6.56 \mathrm{~g} / \mathrm{cm}^{3}$ & \\
\hline
\end{tabular}

Source: Refs. 36 and 37.

${ }^{a}$ ZAID = MCNP data table identifier (refer to Section 6.2).

Table 10. Material specifications for Zircaloy-2

\begin{tabular}{|l|c|c|c|c|c|}
\hline $\begin{array}{c}\text { Element/ } \\
\text { isotope }\end{array}$ & ZAID $^{\boldsymbol{a}}$ & wt \% & $\begin{array}{c}\text { Element/ } \\
\text { isotope }\end{array}$ & ZAID $^{\boldsymbol{a}}$ & wt \% \\
\hline${ }^{50} \mathrm{Cr}$ & $24050.62 \mathrm{c}$ & 0.0042 & ${ }^{58} \mathrm{Ni}$ & $28058.62 \mathrm{c}$ & 0.0370 \\
\hline${ }^{52} \mathrm{Cr}$ & $24052.62 \mathrm{c}$ & 0.0837 & ${ }^{60} \mathrm{Ni}$ & $28060.62 \mathrm{c}$ & 0.0147 \\
\hline${ }^{53} \mathrm{Cr}$ & $24053.62 \mathrm{c}$ & 0.0097 & ${ }^{61} \mathrm{Ni}$ & $28061.62 \mathrm{c}$ & 0.0007 \\
\hline${ }^{54} \mathrm{Cr}$ & $24054.62 \mathrm{c}$ & 0.0024 & ${ }^{62} \mathrm{Ni}$ & $28062.62 \mathrm{c}$ & 0.0021 \\
\hline${ }^{54} \mathrm{Fe}$ & $26054.62 \mathrm{c}$ & 0.0076 & ${ }^{64} \mathrm{Ni}$ & $28064.62 \mathrm{c}$ & 0.0006 \\
\hline${ }^{56} \mathrm{Fe}$ & $26056.62 \mathrm{c}$ & 0.1241 & ${ }^{16} \mathrm{O}$ & $8016.62 \mathrm{c}$ & 0.1250 \\
\hline${ }^{57} \mathrm{Fe}$ & $26057.62 \mathrm{c}$ & 0.0029 & $\mathrm{Zr}-\mathrm{nat}$ & $40000.66 \mathrm{c}$ & 98.1350 \\
\hline${ }^{58} \mathrm{Fe}$ & $26058.62 \mathrm{c}$ & 0.0004 & $\mathrm{Sn}-\mathrm{nat}$ & $50000.42 \mathrm{c}$ & 1.4500 \\
\hline \multicolumn{7}{|c|}{ Density $=6.55 \mathrm{~g} / \mathrm{cm}^{3}$} \\
\hline
\end{tabular}

Source: Refs. 36 and 38.

${ }^{a}$ ZAID = MCNP data table identifier (refer to Section 6.2).

Table 11. Material specifications for SA-240 S30464

\begin{tabular}{|l|c|c|l|c|c|}
\hline $\begin{array}{c}\text { Element/ } \\
\text { isotope }\end{array}$ & ZAID $^{a}$ & wt \% & $\begin{array}{c}\text { Element/ } \\
\text { isotope }\end{array}$ & ZAID $^{a}$ & wt \% \\
\hline C-nat & $6000.66 \mathrm{c}$ & 0.0800 & ${ }^{55} \mathrm{Mn}$ & $25055.62 \mathrm{c}$ & 2.0000 \\
\hline${ }^{14} \mathrm{~N}$ & $7014.62 \mathrm{c}$ & 0.1000 & ${ }^{54} \mathrm{Fe}$ & $26054.62 \mathrm{c}$ & 3.5855 \\
\hline${ }^{10} \mathrm{~B}$ & $5010.66 \mathrm{c}$ & 0.1548 & ${ }^{56} \mathrm{Fe}$ & $26056.62 \mathrm{c}$ & 58.3137 \\
\hline${ }^{11} \mathrm{~B}$ & $5011.66 \mathrm{c}$ & 0.6852 & ${ }^{57} \mathrm{Fe}$ & $26057.62 \mathrm{c}$ & 1.3715 \\
\hline $\mathrm{Si}-\mathrm{nat}$ & $14000.60 \mathrm{c}$ & 0.7500 & ${ }^{58} \mathrm{Fe}$ & $26058.62 \mathrm{c}$ & 0.1843 \\
\hline${ }^{31} \mathrm{P}$ & $15031.66 \mathrm{c}$ & 0.0450 & ${ }^{58} \mathrm{Ni}$ & $28058.62 \mathrm{c}$ & 9.0721 \\
\hline $\mathrm{S}-\mathrm{nat}$ & $16032.62 \mathrm{c}$ & 0.0300 & ${ }^{60} \mathrm{Ni}$ & $28060.62 \mathrm{c}$ & 3.6143 \\
\hline${ }^{50} \mathrm{Cr}$ & $24050.62 \mathrm{c}$ & 0.7939 & ${ }^{61} \mathrm{Ni}$ & $28061.62 \mathrm{c}$ & 0.1598 \\
\hline${ }^{52} \mathrm{Cr}$ & $24052.62 \mathrm{c}$ & 15.9031 & ${ }^{62} \mathrm{Ni}$ & $28062.62 \mathrm{c}$ & 0.5171 \\
\hline${ }^{53} \mathrm{Cr}$ & $24053.62 \mathrm{c}$ & 1.8378 & ${ }^{64} \mathrm{Ni}$ & $28064.62 \mathrm{c}$ & 0.1367 \\
\hline${ }^{54} \mathrm{Cr}$ & $24054.62 \mathrm{c}$ & 0.4652 & ${ }^{59} \mathrm{Co}$ & $27059.66 \mathrm{c}$ & 0.2000 \\
\hline \multicolumn{7}{|c}{ Density $7.8 \mathrm{~g} / \mathrm{cm}^{3}\left(0.282 \mathrm{lb} / \mathrm{in}^{3}\right)$} \\
\hline
\end{tabular}

Source: Refs. 39 and 24.

${ }^{a}$ ZAID = MCNP data table identifier (refer to Section 6.2). 


\subsubsection{Critical Experiment Data}

The following subsections describe critical experiment data that are used as input to this analysis. The critical experiments include public and proprietary Laboratory Critical Experiments (LCEs) and CRCs. Table 12 summarizes the input data used in MCNP and SCALE modeling, their sources, and the justification for use as direct inputs.

Table 12. Critical experiment input data

\begin{tabular}{|c|c|c|c|}
\hline $\begin{array}{c}\text { Critical experiment } \\
\text { set }\end{array}$ & Input description & Source & Justification \\
\hline $\begin{array}{l}\text { Public Laboratory } \\
\text { Critical Experiments }\end{array}$ & $\begin{array}{l}\text { Experimental configurations, } \\
\text { material compositions, experimental } \\
k_{\text {eff }} \text { value, benchmark model } \\
\text { uncertainty }\end{array}$ & Ref. 45. & Established fact \\
\hline $\begin{array}{l}\text { Proprietary Haut Taux } \\
\text { de Combustion LCEs }\end{array}$ & $\begin{array}{l}\text { Experimental configurations, } \\
\text { material compositions, experimental } \\
k_{\text {eff }} \text { value, benchmark model } \\
\text { uncertainty }\end{array}$ & $\begin{array}{l}\text { Refs. } 46,47, \\
48,49,50 .\end{array}$ & YMP qualified data (Ref. 51) \\
\hline $\begin{array}{l}\text { Crystal River Unit } 3 \\
\text { CRCs }\end{array}$ & $\begin{array}{l}\text { Calculation descriptions and MCNP } \\
\text { input files }\end{array}$ & $\begin{array}{l}\text { Refs. } 52 \text { and } \\
53 .\end{array}$ & $\begin{array}{l}\text { Approved technical products } \\
\text { developed in accordance with } \\
\text { QARD requirements }\end{array}$ \\
\hline $\begin{array}{l}\text { McGuire Unit } 1 \\
\text { CRCs }\end{array}$ & $\begin{array}{l}\text { Calculation descriptions and MCNP } \\
\text { input files }\end{array}$ & $\begin{array}{l}\text { Refs. } 54 \text { and } \\
55 .\end{array}$ & $\begin{array}{l}\text { Approved technical products } \\
\text { developed in accordance with } \\
\text { QARD requirements }\end{array}$ \\
\hline $\begin{array}{l}\text { Sequoyah Unit } 2 \\
\text { CRCs }\end{array}$ & $\begin{array}{l}\text { Calculation descriptions and MCNP } \\
\text { input files }\end{array}$ & $\begin{array}{l}\text { Refs. } 56 \text { and } \\
57 .\end{array}$ & $\begin{array}{l}\text { Approved technical products } \\
\text { developed in accordance with } \\
\text { QARD requirements }\end{array}$ \\
\hline $\begin{array}{l}\text { Three Mile Island } \\
\text { Unit } 1 \text { CRCs }\end{array}$ & $\begin{array}{l}\text { Calculation descriptions and MCNP } \\
\text { input files }\end{array}$ & $\begin{array}{l}\text { Refs. } 58 \text { and } \\
59 .\end{array}$ & $\begin{array}{l}\text { Approved technical products } \\
\text { developed in accordance with } \\
\text { QARD requirements }\end{array}$ \\
\hline $\begin{array}{l}\text { Grand Gulf Unit } 1 \\
\text { CRCs }\end{array}$ & $\begin{array}{l}\text { Calculation descriptions and MCNP } \\
\text { input files }\end{array}$ & Ref. 60. & $\begin{array}{l}\text { Approved technical product } \\
\text { developed in accordance with } \\
\text { QARD requirements }\end{array}$ \\
\hline
\end{tabular}

\subsubsection{Public Laboratory Critical Experiment Data}

The data source of publicly available LCEs included as a component of validation methodology is found in the International Handbook of Evaluated Criticality Safety Benchmark Experiments (IHECSBE) ${ }^{45}$ from the Nuclear Energy Agency of the Organization for Economic Co-Operation and Development (OECDNEA). The IHECSBE contains evaluations of criticality benchmark experiments that have been peer reviewed and have a detailed description of relevant experimental conditions. MCNP and CSAS25/KENO V.a modeling directly uses the critical experiment descriptions available in the IHECSBE. Another input to the validation methodology obtained from the IHECSBE is experimental $k_{\text {eff }}$ value.

\subsubsection{Proprietary LCE Data-Haut Taux de Combustion Critical Experiments}

Haut Taux de Combustion (HTC) (French for "high burnup") LCE descriptions are data qualified per YMP applicable procedures. ${ }^{46,51}$ The HTC data are acceptable for the intended use since these experiments were performed to support criticality validation, were evaluated and documented to be consistent with the IHECSBE guidelines, and were performed by the same facility and organization that 
has produced many data reports already accepted as qualified for the International Handbook of Evaluated Criticality Safety Benchmark Experiments, the internationally recognized and accepted source for LCE data.

\subsubsection{Commercial Reactor Criticals}

The CRC data considered in this validation consist of 45 state-points from five PWRs: Crystal River Unit 3 (33 configurations), McGuire Unit 1 (six configurations), Sequoyah Unit 2 (three configurations), and Three Mile Island (TMI) Unit 1 (three configurations), and 16 state-points from BWR Grand Gulf Unit 1. CRC state-point configuration descriptions are documented in approved YMP reports. ${ }^{52,54,56,58,60}$ The MCNP calculations documented in this report for Crystal River Unit 3, McGuire Unit 1, Sequoyah Unit 2, TMI Unit 1, and Grand Gulf Unit 1 state-points used the MCNP input files from Refs. 53, 55, 57, 59, and 60, respectively, as direct input. Those files were modified as described in Section 6.3.3.

General information for the selected CRC state-points, including core average burnup, cycle length to state-point, and cycle downtime, is presented in Table 13. Core average burnup was used as a direct technical input to this calculation. 
Table 13. General information for selected CRC state-points

\begin{tabular}{|c|c|c|c|c|c|}
\hline $\begin{array}{l}\text { State- } \\
\text { point }\end{array}$ & Cycle & 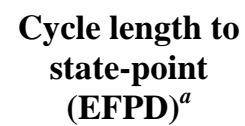 & $\begin{array}{c}\text { Enrichments } \\
\left(w \mathrm{t} \%{ }^{235} \mathrm{U} \text { in } \mathrm{U} \text { of } \mathrm{U} \mathrm{O}_{2}\right)^{b}\end{array}$ & $\begin{array}{c}\text { Cycle } \\
\text { downtime } \\
\text { (days) }\end{array}$ & $\begin{array}{c}\text { Core average } \\
\text { burnup } \\
\text { (GWd/MTU) }\end{array}$ \\
\hline \multicolumn{6}{|c|}{ Crystal River Unit 3} \\
\hline 1 & $1 \mathrm{~A}$ & 0.0 & $(1.93,2.54,2.83)$ & 0.0 & 0.00 \\
\hline 2 & $1 \mathrm{~B}$ & 268.8 & $1.93,2.00,2.54,2.83$ & 195.3 & 8.09 \\
\hline 3 & 1B & 411.0 & $1.93,2.00,2.54,2.83$ & 14.8 & 12.34 \\
\hline 4 & 2 & 0.0 & $2.54,(2.64), 2.83$ & 97.0 & 8.67 \\
\hline 5 & 3 & 0.0 & $2.54,(2.62), 2.64,2.83$ & 164.0 & 7.50 \\
\hline 6 & 3 & 168.5 & $2.54,2.62,2.64,2.83$ & 16.8 & 12.54 \\
\hline 7 & 3 & 250.0 & $2.54,2.62,2.64,2.83$ & 12.3 & 14.98 \\
\hline 8 & 4 & 0.0 & $2.62,(2.62), 2.64,(2.95)$ & 73.0 & 6.92 \\
\hline 9 & 4 & 228.1 & $2.62,2.64,2.95$ & 15.2 & 14.00 \\
\hline 10 & 4 & 253.0 & $2.62,2.64,2.95$ & 24.0 & 14.77 \\
\hline 11 & 5 & 0.0 & $2.62,2.64,2.95,(2.95,3.29)$ & 127.0 & 7.08 \\
\hline 12 & 5 & 388.5 & $2.62,2.64,2.95,2.95,3.29$ & 5.0 & 19.12 \\
\hline 13 & 6 & 0.0 & $2.62,2.64,2.95,3.29,(3.49)$ & 163.0 & 12.01 \\
\hline 14 & 6 & 96.0 & $2.62,2.64,2.95,3.29,3.49$ & 168.9 & 14.99 \\
\hline 15 & 6 & 400.0 & $2.62,2.64,2.95,3.29,3.49$ & 10.4 & 24.41 \\
\hline 16 & 7 & 0.0 & $2.54,2.62,2.64,3.29,3.49,(3.84)$ & 113.0 & 10.02 \\
\hline 17 & 7 & 260.3 & $2.54,2.62,2.64,3.29,3.49,3.84$ & 18.9 & 18.09 \\
\hline 18 & 7 & 291.0 & $2.54,2.62,2.64,3.29,3.49,3.84$ & 39.5 & 19.04 \\
\hline 19 & 7 & 319.0 & $2.54,2.62,2.64,3.29,3.49,3.84$ & 109.5 & 19.91 \\
\hline 20 & 7 & 462.3 & $2.54,2.62,2.64,3.29,3.49,3.84$ & 2.2 & 24.35 \\
\hline 21 & 7 & 479.0 & $2.54,2.62,2.64,3.29,3.49,3.84$ & 7.2 & 24.87 \\
\hline 22 & 8 & 0.0 & $1.93,2.62,3.29,3.49,3.84,(3.94)$ & 99.0 & 12.26 \\
\hline 23 & 8 & 97.6 & $1.93,2.62,3.29,3.49,3.84,3.94$ & 15.5 & 15.27 \\
\hline 24 & 8 & 139.8 & $1.93,2.62,3.29,3.49,3.84,3.94$ & 6.2 & 16.58 \\
\hline 25 & 8 & 404.0 & $1.93,2.62,3.29,3.49,3.84,3.94$ & 44.4 & 24.74 \\
\hline 26 & 8 & 409.6 & $1.93,2.62,3.29,3.49,3.84,3.94$ & 4.9 & 24.91 \\
\hline 27 & 8 & 515.5 & $1.93,2.62,3.29,3.49,3.84,3.94$ & 7.6 & 28.19 \\
\hline 28 & 9 & 0.0 & $1.93,3.84,(3.90), 3.94$ & 75.0 & 14.18 \\
\hline 29 & 9 & 158.8 & $1.93,3.84,3.90,3.94$ & 2.1 & 19.10 \\
\hline 30 & 9 & 219.0 & $1.93,3.84,3.90,3.94$ & 53.1 & 20.96 \\
\hline 31 & 9 & 363.1 & $1.93,3.84,3.90,3.94$ & 1.6 & 25.42 \\
\hline 32 & 10 & 0.0 & $3.84,3.90,3.94,(4.167)$ & 55.0 & 15.24 \\
\hline 33 & 10 & 573.7 & $3.84,3.90,3.94,4.167$ & 16.4 & 33.00 \\
\hline
\end{tabular}


Table 13. General information for selected CRC state-points (continued)

\begin{tabular}{|c|c|c|c|c|c|}
\hline $\begin{array}{l}\text { State- } \\
\text { point }\end{array}$ & Cycle & 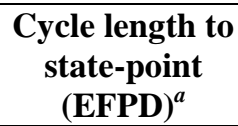 & $\begin{array}{c}\text { Enrichments } \\
\left(w \mathrm{t} \%{ }^{235} \mathrm{U} \text { in } \mathrm{U} \text { of } \mathrm{UO}_{2}\right)^{b}\end{array}$ & $\begin{array}{c}\text { Cycle } \\
\text { downtime } \\
\text { (days) }\end{array}$ & $\begin{array}{c}\text { Core average } \\
\text { burnup } \\
\text { (GWd/MTU) }\end{array}$ \\
\hline \multicolumn{6}{|c|}{ Three Mile Island Unit 1} \\
\hline 1 & 1 & 0 & $(2.06,2.75,3.05)$ & 0 & 0.00 \\
\hline 2 & 5 & 0 & $2.64,2.85,(2.85)$ & 2,420 & 10.33 \\
\hline 3 & 5 & 114.4 & $2.64,2.85$ & 32.2 & 13.87 \\
\hline \multicolumn{6}{|c|}{ McGuire Unit 1} \\
\hline 1 & 1 & 0.0 & $(2.108,2.601,3.106)$ & 0.0 & 0.00 \\
\hline 2 & 6 & 0.0 & $2.92,3.204,3.40,(3.60)$ & 78.0 & 11.67 \\
\hline 3 & 6 & 62.4 & $2.92,3.204,3.40,3.60$ & 62.7 & 14.34 \\
\hline 4 & 7 & 0.0 & $2.92,3.204,3.40,3.60,(3.75)$ & 130.0 & 10.76 \\
\hline 5 & 7 & 129.0 & $2.92,3.204,3.40,3.60,3.75$ & 29.6 & 16.14 \\
\hline 6 & 7 & 282.3 & $2.92,3.204,3.40,3.60,3.75$ & 18.8 & 22.54 \\
\hline \multicolumn{6}{|c|}{ Sequoyah Unit 2} \\
\hline 1 & 1 & 0.0 & $(2.10,2.60,3.10)$ & 0.0 & 0.00 \\
\hline 2 & 3 & 0.0 & $2.60,3.10,3.50,(3.60,3.80)$ & 81.0 & 11.11 \\
\hline 3 & 3 & 210.9 & $2.60,3.10,3.50,3.60,3.80$ & 995.7 & 19.20 \\
\hline \multicolumn{6}{|c|}{$\begin{array}{c}\text { Grand Gulf } \\
\end{array}$} \\
\hline 5 & 4 & 0.00 & $2.81,3.01,(3.25,3.37)$ & 41.4 & 11.00 \\
\hline 6 & 4 & 4.01 & $2.81,3.01,3.25,3.37$ & 17.7 & 11.00 \\
\hline 7 & 4 & 73.49 & $2.81,3.01,3.25,3.37$ & 8.5 & 13.00 \\
\hline 10 & 5 & 0.00 & $3.01,3.25,3.37,(3.42)$ & 55.8 & 13.00 \\
\hline 11 & 5 & 16.54 & $3.01,3.25,3.37,3.42$ & 11.4 & 13.00 \\
\hline 12 & 5 & 148.27 & $3.01,3.25,3.37,3.42$ & 4.8 & 17.00 \\
\hline 13 & 5 & 165.29 & $3.01,3.25,3.37,3.42$ & 3.5 & 17.00 \\
\hline 14 & 5 & 203.58 & $3.01,3.25,3.37,3.42$ & 7.7 & 18.00 \\
\hline 15 & 5 & 340.41 & $3.01,3.25,3.37,3.42$ & 10.3 & 22.00 \\
\hline 16 & 6 & 0.00 & $3.25,3.37,3.42,(2.94,3.38)$ & 48.3 & 13.00 \\
\hline 18 & 7 & 0.00 & $2.94,3.38,3.42,(3.20,3.42)$ & 60.0 & 14.00 \\
\hline 19 & 7 & 108.81 & $2.94,3.38,3.42,3.20,3.42$ & 5.8 & 17.00 \\
\hline 20 & 7 & 245.05 & $2.94,3.38,3.42,3.20,3.42$ & 3.9 & 20.00 \\
\hline 21 & 8 & 0.00 & $2.94,3.20,3.38,3.42,(3.07,3.56)$ & 56.2 & 13.00 \\
\hline 22 & 8 & 0.00 & $2.94,3.20,3.38,3.42,(3.07,3.56)$ & 3.8 & 13.00 \\
\hline 23 & 8 & 17.59 & $2.94,3.20,3.38,3.42,3.07,3.56$ & 4.4 & 14.00 \\
\hline
\end{tabular}

Source: Ref. 61.

${ }^{a}$ Effective full-power days.

${ }^{b}$ Fresh fuel enrichment at the beginning of a cycle is shown in parentheses. 


\subsection{CRITERIA}

The safety criteria for postclosure criticality are best described in Criticality Input to Canister Based System Performance Specification for Disposal (Ref. 62) as follows:

There are no specific design criteria for postclosure criticality control in 10 CFR Part 63 but requirements are consistent with a risk-informed, performance-based regulation, which treats criticality in 10 CFR Part 63 as one of the features, events, processes that must be considered for the overall system performance assessment, i.e.:

...The features, events, and processes considered in the performance assessment should represent a wide range of both beneficial and potentially adverse effects on performance (e.g., beneficial effects of radionuclide sorption; potentially adverse effects of fracture flow or a criticality event).... [§ 63.102(j)]

Various measures are implemented to satisfy the 10 CFR Part 63 acceptance criteria applicable to the postclosure performance assessment for the Yucca Mountain site; these include examining the significant factors contributing to the probability of criticality in the repository and possibly implementing additional analyses or design enhancements to reduce the overall probability of criticality if the respective criteria are exceeded. Such measures are addressed in 10 CFR Part 63, which, in discussing "concepts" of the performance assessment regulations, states in part:

...Those features, events, and processes expected to materially affect compliance with $\S 63.113(\mathrm{~b})$ or be potentially adverse to performance are included, while events (event classes or scenario classes) that are very unlikely (less than one chance in 10,000 over 10,000 years) can be excluded from the analysis... [§ 63.102(j)]

\subsection{INDUSTRY STANDARDS AND FEDERAL REGULATIONS}

Applicable Code of Federal Regulations is

- 10 CFR 63 Parts: 113(b), 113(c), 114(d) through 114(f).

The following standards are used as the bases of validation methodology presented in this report:

- ANSI/ANS-8.1-1998. Nuclear Criticality Safety in Operations with Fissionable Material Outside Reactors.

- ANSI/ANS-8.17-2004. Criticality Safety Criteria for the Handling, Storage, and Transportation of LWR Fuel Outside Reactors.

The following codes and standards are used as direct input to material composition calculations:

- 2001 ASME Boiler and Pressure Vessel Code (includes 2002 addenda).

- ASTM G 1-90 (Reapproved 1999). Standard Practice for Preparing, Cleaning, and Evaluating Corrosion Test Specimens.

- ASTM B 811-97. Standard Specification for Wrought Zirconium Alloy Seamless Tubes for Nuclear Reactor Fuel Cladding. 
- ASTM A 887-89 (Reapproved 2004). Standard Specification for Borated Stainless Steel Plate, Sheet, and Strip for Nuclear Application. 


\section{ASSUMPTIONS}

1. It is assumed that the CRC $k_{\text {eff }}$ values have an uncertainty of $1 \%$ (one standard deviation) due to uncertainties in various CRC model components (e.g., isotopic compositions of burned fuel, operation history, physical and material specifications data). The rationale for this assumption is provided in Section 6.3.3. The assumption is used in the calculations and analyses described in Section 6.5.2.

2. It is assumed that the CRCs considered in this validation, other than the Crystal River CRCs, have similar integral $c_{k}$ values to the $c_{k}$ values determined for the Crystal River CRCs. The rationale for this assumption is that the CRCs are reactor critical configurations with similar material compositions and geometry. The assumption is used in the calculations and analyses described in Section 6.5.2. 



\section{VALIDATION METHODOLOGY}

The process used to validate the computational method for postclosure criticality of CSNF waste packages applies the disposal criticality analysis methodology approach documented in Section 3.5.1 of the Disposal Criticality Analysis Methodology Topical Report, ${ }^{1}$ which is illustrated in Figure 2 . The methodology is based on the guidance in ANSI/ANS 8.1-1998 and ANSI/ANS 8.17-2004.

The validation is comprised of the following steps:

- Identify the application systems and the range of parameters and conditions for which the validation will apply (see Section 6.1).

- Identify the computer code implementing the physics and numerical techniques and the cross sections to be used in all calculations (see Section 6.2).

- Select critical experiments for consideration based on similarities in physical characteristics between the application systems and critical experiments (see Section 6.3).

- Identify applicable critical experiments based on neutronic similarity between the application systems and the selected critical experiments, as determined by the sensitivity/uncertainty (TSUNAMI) computational tools. Use the published (Refs. 63 and 64) guidance for similarity criteria based on experience at ORNL to identify applicable critical experiments (see Section 6.4).

- Determine bias and bias uncertainty over the area of applicability using industry and NRC accepted tools and procedures (Ref. 18). Only critical experiments that have neutronic similarities, that is, similar material compositions, neutron spectra, and leakage, with the application systems are used in the determination of bias and uncertainty associated with the bias (see Section 6.5). 


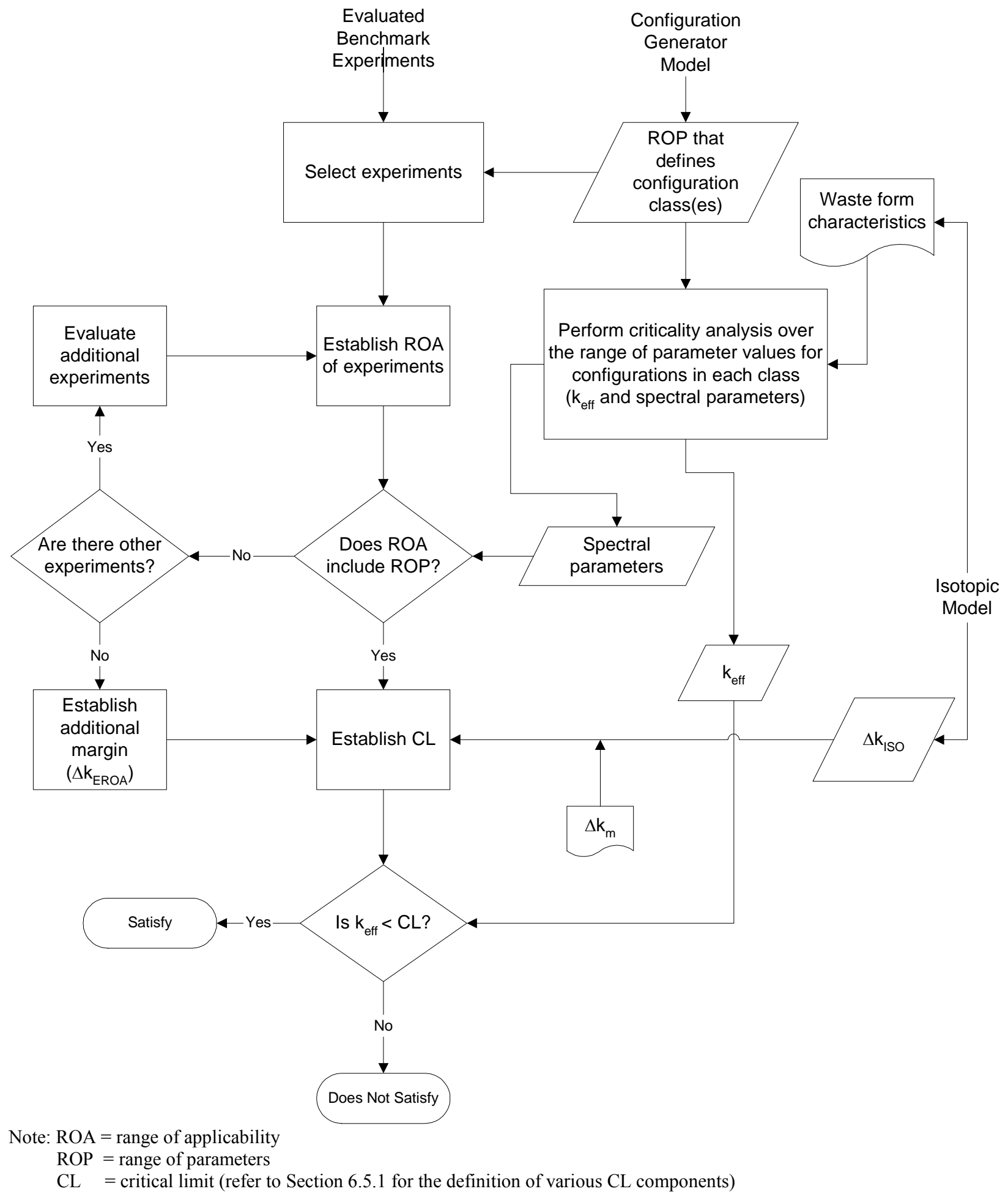

Fig. 2. Criticality model overview. 


\subsection{RANGE OF PARAMETERS TO BE VALIDATED}

The application systems for this validation consist of waste packages containing TAD canisters loaded with CSNF of varying assembly types, initial enrichments, and burnups that are expected from the waste stream. The evaluated systems will have varying degrees of waste package internal component degradation that may occur over the 10,000-year regulatory time period.

The PWR and BWR assembly types selected for the various calculations and analyses presented in this report are Babcock and Wilcox $(\mathrm{B} \& W) 15 \times 15$ and General Electric $(\mathrm{GE}) 7 \times 7$, respectively. The basis for the selection is that the $\mathrm{B} \& \mathrm{~W} 15 \times 15$ and the GE $7 \times 7$ assemblies are more reactive in a waste package configuration than other PWR and BWR assembly types, respectively, as documented in Ref. 43, Attachment II, and Ref. 44, Attachment I, respectively. For each type of assembly, several initial enrichment-burnup (initial enrichment in $\mathrm{wt}^{2} \%{ }^{235} \mathrm{U}$ and burnup in $\mathrm{GWd} / \mathrm{MTU}$ ) pairs were selected. For the B\&W $15 \times 15$ assemblies, these pairs are: $2 \%-0 \mathrm{GWd} / \mathrm{MTU}, 3 \%-0 \mathrm{GWd} / \mathrm{MTU}, 3 \%-15 \mathrm{GWd} / \mathrm{MTU}$, 3.5\%-25 GWd/MTU, 4\%-30 GWd/MTU, 4.5\%-35 GWd/MTU, and 5\%-40 GWd/MTU, whereas for the GE $7 \times 7$ assemblies, the pairs are: 3\%-0 GWd/MTU, 3\%-10 GWd/MTU, 4\%-0 GWd/MTU, 4\%-20 $\mathrm{GWd} / \mathrm{MTU}$, and 5\%-30 GWd/MTU. The selected CSNF assembly types with the selected maximum initial enrichment-minimum burnup combinations are more reactive than the majority of the waste stream assemblies, as can be seen from Figs. 2 and 3, which illustrate the selected initial enrichment-burnup pairs relative to the PWR and BWR waste stream inventories, respectively. The waste stream, as illustrated in Figs. 3 and 4, is represented by 1999 discharge data (Refs. 65 and 66) that correspond to CSNF assemblies discharged from U.S. PWRs through the end of 1999. 


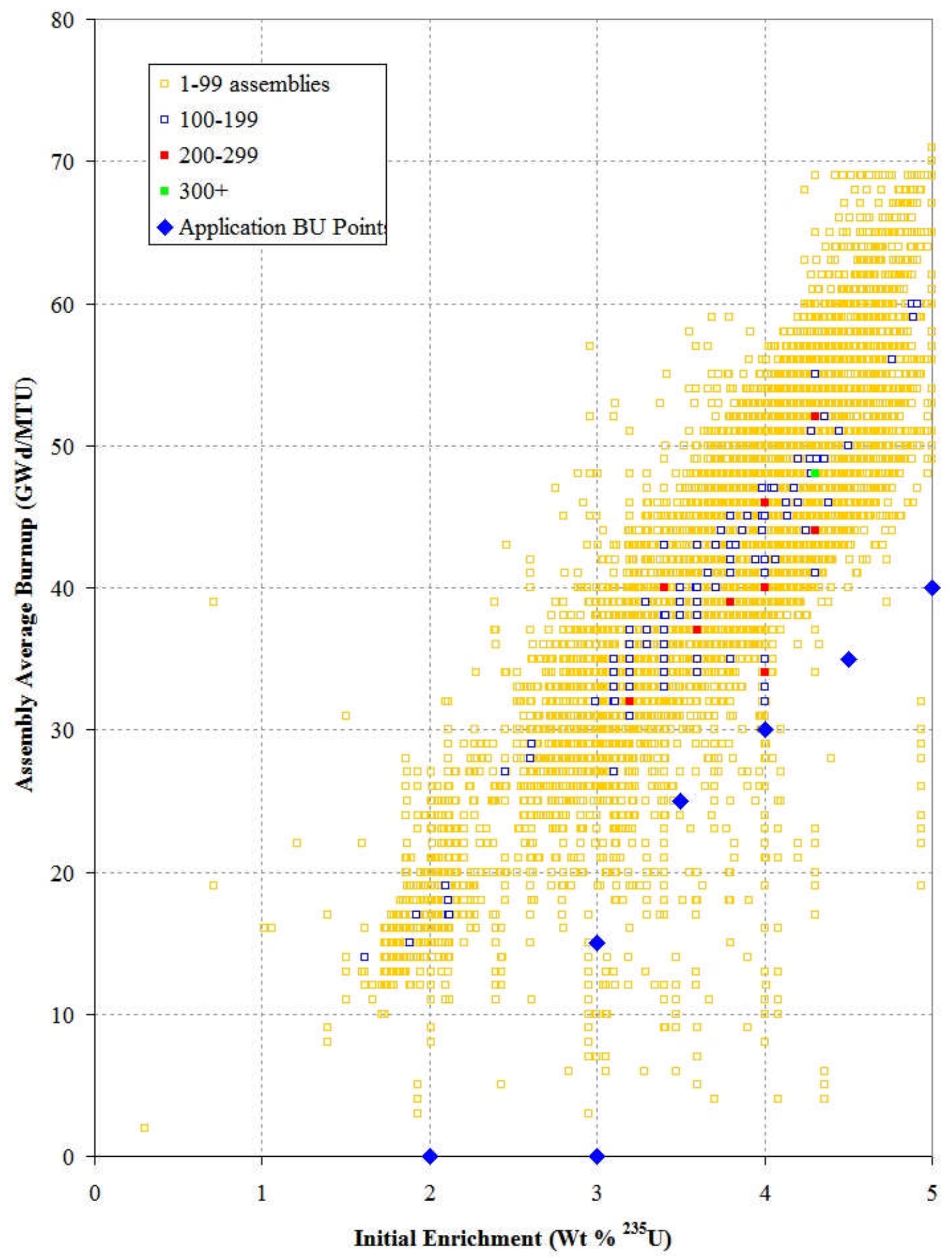

Note: $B U=$ burnup

Fig. 3. PWR inventory and application burnup points. 


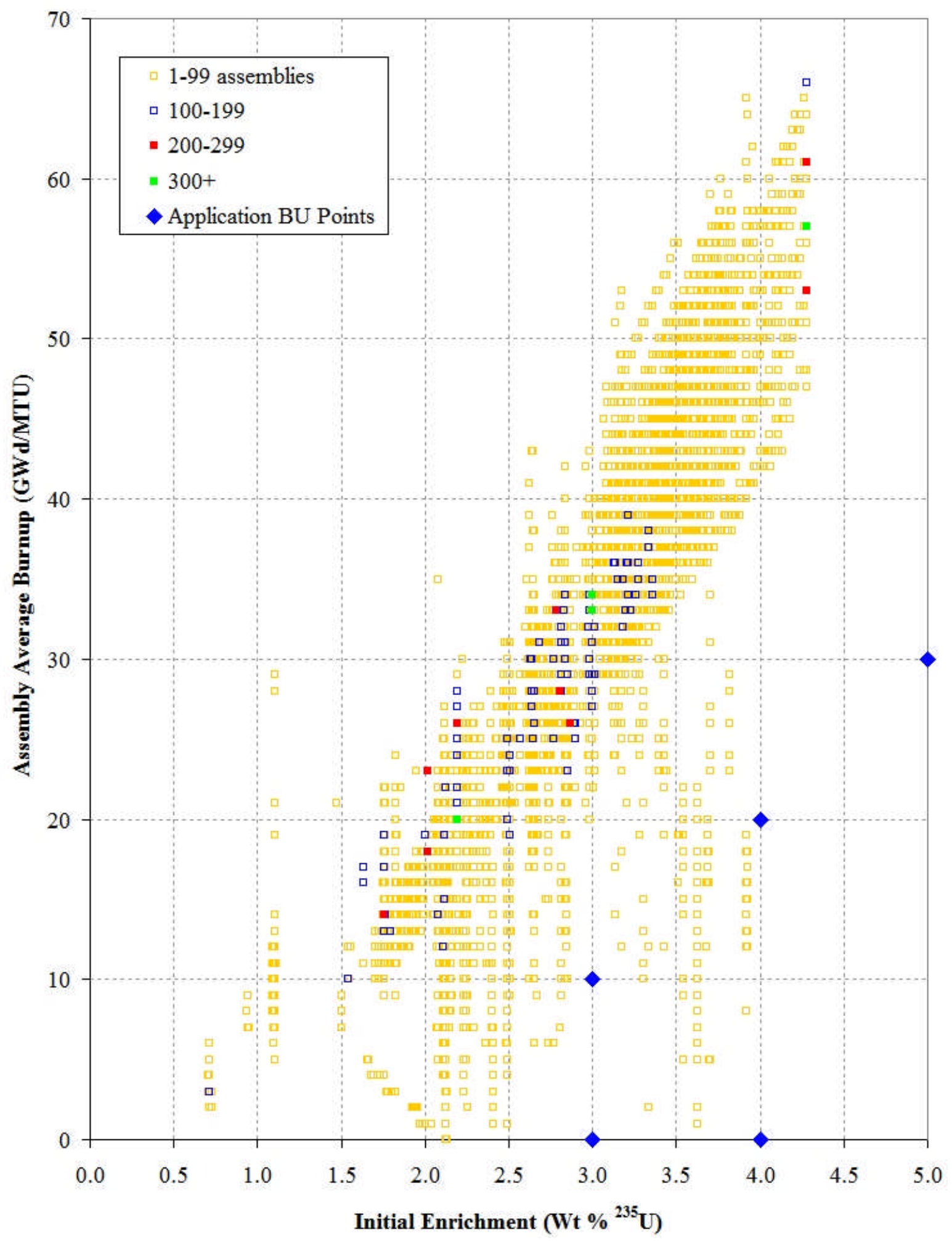

Note: $B U=$ burnup

Fig. 4. BWR inventory and application burnup points. 
During the postclosure time period, processes and events may occur that degrade the contents of the waste package after the package has been breached and the inert environment lost. Two waste package configurations for each CSNF type are investigated: a waste package configuration consisting of intact CSNF assemblies and intact fuel basket, which will be referred to as "nominal configuration" throughout this report, and a waste package configuration consisting of intact assemblies and degraded waste package basket plates, which will be referred to as "design-basis configuration" throughout this report. For the design-basis configuration, the thickness of the borated stainless steel plates was reduced from $1.1112 \mathrm{~cm}$ (nominal thickness) to $0.6 \mathrm{~cm}$ to account for corrosion degradation over the 10,000-year time period from emplacement (Ref. 26). For both nominal and design-basis configurations, the modeled borated stainless steel chemical composition contains only $75 \%$ of the actual ${ }^{10} \mathrm{~B}$ weight fraction for conservatism in the $k_{\text {eff }}$ estimations. The PWR assemblies contain a seven-zone axial burnup profile, whereas the BWR assemblies have a uniform axial burnup profile. To ensure conservatism throughout the 10,000-year regulatory time frame, all computational models use spent fuel compositions at 5-year cooling time (Ref. 67). The selected application systems and modeling parameters for these systems are considered adequate for the purpose of this calculation since they are used only to identify applicable critical experiments to the validation of criticality calculations for CSNF waste packages and not directly used in determining the LBTL.

Consistent with the Disposal Criticality Analysis Methodology Topical Report (Ref. 1), the criticality analysis model uses a subset of the isotopes present in the CSNF that consists of 14 actinides and 15 fission products, referred to as "Principal Isotopes." The principal isotopes are presented in Table 14.

Table 14. Principal isotopes for CSNF burnup credit

\begin{tabular}{|c|c||c|c|}
\hline \multicolumn{2}{|c||}{ Actinide isotopes } & \multicolumn{2}{c|}{ Fission product isotopes } \\
\hline${ }^{233} \mathrm{U}$ & ${ }^{239} \mathrm{Pu}$ & ${ }^{95} \mathrm{Mo}$ & ${ }^{149} \mathrm{Sm}$ \\
\hline${ }^{234} \mathrm{U}$ & ${ }^{240} \mathrm{Pu}$ & ${ }^{99} \mathrm{Tc}$ & ${ }^{150} \mathrm{Sm}$ \\
\hline${ }^{235} \mathrm{U}$ & ${ }^{241} \mathrm{Pu}$ & ${ }^{101} \mathrm{Ru}$ & ${ }^{151} \mathrm{Sm}$ \\
\hline${ }^{236} \mathrm{U}$ & ${ }^{242} \mathrm{Pu}$ & ${ }^{103} \mathrm{Rh}$ & $\mathrm{Sm}$ \\
\hline${ }^{238} \mathrm{U}$ & ${ }^{241} \mathrm{Am}$ & ${ }^{159} \mathrm{Eu}$ \\
\hline${ }^{237} \mathrm{~Np}$ & ${ }^{242 \mathrm{~m}} \mathrm{Am}$ & ${ }^{a}$ & ${ }^{153} \mathrm{Eu}$ \\
\hline${ }^{238} \mathrm{Pu}$ & ${ }^{243} \mathrm{Am}$ & ${ }^{143} \mathrm{Nd}$ & ${ }^{155} \mathrm{Gd}$ \\
\hline & & ${ }^{145} \mathrm{Nd}$ & \\
\hline
\end{tabular}

${ }^{\mathrm{a}}$ The $m$ refers to a long-lived metastable state of ${ }^{242} \mathrm{Am}$.

Note: Isotopes with very low atom densities were omitted from the MCNP and SCALE compositions (e.g., ${ }^{233} \mathrm{U}$ atom densities below 5.0E-11 atoms/barn-cm).

\subsection{COMPUTATIONAL TOOLS AND NUCLEAR CROSS-SECTION DATA FOR CRITICALITY CALCULATIONS}

The computational tool and nuclear data to be validated are MCNP and the nuclear data identified in Table 15. MCNP is a general-purpose Monte Carlo computer code that is routinely used for criticality safety applications and has been accepted by the NRC for applications involving CSNF (e.g., Ref. 25). A Monte Carlo calculation is a numerical simulation of the actual physical process (e.g., neutron transport and interactions with matter) that determines the value of a physical quantity as the expected value of a certain random variable (or combination of several variables). The method of source iteration or successive generations serves as the basis of a Monte Carlo simulation for the statistical estimation of the effective multiplication factor, $k_{\text {eff }}$, for a nuclear system. In this method, $k_{\text {eff }}$ is computed as the mean number of fission neutrons produced in one generation per fission neutron started. MCNP allows for an 
accurate material and geometry representation of the application configurations. Thus, the method statistically evaluates the system with few approximations. However, the MCNP results represent statistical estimates with associated uncertainties. In criticality calculations, collision, absorption, and track-length $k_{\text {eff }}$ estimators are computed and the recommended (Ref. 3) $k_{\text {eff }}$ and confidence interval are based on a combination of the three estimators. All MCNP calculated $k_{\text {eff }}$ values cited in this report correspond to this recommended $k_{\text {eff }}$ estimator. The quality of a calculated $k_{\text {eff }}$ value and confidence interval depends on a series of factors, including material and geometric model representation and whether the fission-source distribution has converged.

The MCNP continuous-energy data identifiers for the various nuclides used in the waste package models are listed in Table 15. The selected MCNP ZAIDs for waste package/TAD material compositions were used consistently throughout the MCNP calculations for application and experiment systems. A data table identifier in MCNP is called a ZAID and contains the atomic number Z, mass number A, and a library specifier ID. The library specifiers related to the ENDF/B-VI library are 49c, 60c, 62c, or 66c. MCNP data tables based on the ENDF/B-VI library were used where available. For the few nuclides that ENDF/B-VI data are not available with MCNP, data tables based on either the ENDF/B-V library $(\mathrm{ID}=50 \mathrm{c})$ or LLNL ENDL92FP library $(\mathrm{ID}=42 \mathrm{c})^{3}$ were used, as shown in Table 15. 
Table 15. Selected MCNP ZAIDs for waste package/TAD material compositions

\begin{tabular}{|c|c|c|c|c|c|}
\hline Element & Isotope & $\begin{array}{c}\text { Neutron } \\
\text { cross-section library } \\
\text { ZAID }^{a} \\
\end{array}$ & Element & Isotope & $\begin{array}{c}\text { Neutron } \\
\text { cross-section library } \\
\text { ZAID }\end{array}$ \\
\hline Hydrogen & ${ }^{1} \mathrm{H}$ & $1001.62 \mathrm{c}$ & Technetium & ${ }^{99} \mathrm{Tc}$ & $43099.66 \mathrm{c}$ \\
\hline \multirow[t]{2}{*}{ Boron } & ${ }^{10} \mathrm{~B}$ & $5010.66 \mathrm{c}$ & Ruthenium & ${ }^{101} \mathrm{Ru}$ & $44101.50 \mathrm{c}$ \\
\hline & ${ }^{11} \mathrm{~B}$ & $5011.66 \mathrm{c}$ & Rhodium & ${ }^{103} \mathrm{Rh}$ & $45103.66 \mathrm{c}$ \\
\hline Carbon & $\mathrm{C}$ (natural) & $6000.66 c$ & Silver & ${ }^{109} \mathrm{Ag}$ & $47109.66 \mathrm{c}$ \\
\hline Nitrogen & ${ }^{14} \mathrm{~N}$ & $7014.62 \mathrm{c}$ & Tin & Sn (natural) & $50000.42 \mathrm{c}$ \\
\hline Oxygen & ${ }^{16} \mathrm{O}$ & $8016.62 c$ & \multirow[t]{2}{*}{ Neodymium } & ${ }^{143} \mathrm{Nd}$ & $60143.50 \mathrm{c}$ \\
\hline Sodium & ${ }^{23} \mathrm{Na}$ & $11023.62 \mathrm{c}$ & & ${ }^{145} \mathrm{Nd}$ & $60145.50 \mathrm{c}$ \\
\hline Magnesium & $\mathrm{Mg}$ (natural) & $12000.62 \mathrm{c}$ & \multirow[t]{5}{*}{ Samarium } & ${ }^{147} \mathrm{Sm}$ & $62147.66 \mathrm{c}$ \\
\hline Aluminum & ${ }^{27} \mathrm{Al}$ & $13027.62 \mathrm{c}$ & & ${ }^{149} \mathrm{Sm}$ & $62149.66 \mathrm{c}$ \\
\hline Silicon & $\mathrm{Si}$ (natural) & $14000.60 \mathrm{c}$ & & ${ }^{150} \mathrm{Sm}$ & $62150.49 c$ \\
\hline Phosphorus & ${ }^{31} \mathrm{P}$ & $15031.66 \mathrm{c}$ & & ${ }^{151} \mathrm{Sm}$ & $62151.50 \mathrm{c}$ \\
\hline Sulfur & ${ }^{32} \mathrm{~S}$ & $16032.62 \mathrm{c}$ & & ${ }^{152} \mathrm{Sm}$ & $62152.49 c$ \\
\hline Potassium & $\mathrm{K}$ (natural) & $19000.62 \mathrm{c}$ & \multirow[t]{2}{*}{ Europium } & ${ }^{151} \mathrm{Eu}$ & $63151.66 \mathrm{c}$ \\
\hline Calcium & $\mathrm{Ca}$ (natural) & $20000.62 c$ & & ${ }^{153} \mathrm{Eu}$ & $63153.66 \mathrm{c}$ \\
\hline Titanium & Ti (natural) & $22000.62 c$ & Gadolinium & ${ }^{155} \mathrm{Gd}$ & $64155.66 \mathrm{c}$ \\
\hline Vanadium & V (natural) & $23000.62 \mathrm{c}$ & \multirow[t]{4}{*}{ Tungsten } & ${ }^{182} \mathrm{~W}$ & $74182.62 \mathrm{c}$ \\
\hline \multirow[t]{4}{*}{ Chromium } & ${ }^{50} \mathrm{Cr}$ & $24050.62 \mathrm{c}$ & & ${ }^{183} \mathrm{~W}$ & $74183.62 \mathrm{c}$ \\
\hline & ${ }^{52} \mathrm{Cr}$ & $24052.62 c$ & & ${ }^{184} \mathrm{~W}$ & $74184.62 \mathrm{c}$ \\
\hline & ${ }^{53} \mathrm{Cr}$ & $24053.62 c$ & & ${ }^{186} \mathrm{~W}$ & $74186.62 \mathrm{c}$ \\
\hline & ${ }^{54} \mathrm{Cr}$ & $24054.62 c$ & \multirow[t]{5}{*}{ Uranium } & ${ }^{233} \mathrm{U}$ & $92233.66 c$ \\
\hline Manganese & ${ }^{55} \mathrm{Mn}$ & $25055.62 \mathrm{c}$ & & ${ }^{234} \mathrm{U}$ & $92234.66 \mathrm{c}$ \\
\hline \multirow[t]{4}{*}{ Iron } & ${ }^{54} \mathrm{Fe}$ & $26054.62 \mathrm{c}$ & & ${ }^{235} \mathrm{U}$ & $92235.66 \mathrm{c}$ \\
\hline & ${ }^{56} \mathrm{Fe}$ & $26056.62 c$ & & ${ }^{236} \mathrm{U}$ & $92236.66 \mathrm{c}$ \\
\hline & ${ }^{57} \mathrm{Fe}$ & $26057.62 c$ & & ${ }^{238} \mathrm{U}$ & $92238.66 \mathrm{c}$ \\
\hline & ${ }^{58} \mathrm{Fe}$ & $26058.62 \mathrm{c}$ & Neptunium & ${ }^{237} \mathrm{~Np}$ & $93237.66 \mathrm{c}$ \\
\hline Cobalt & ${ }^{59} \mathrm{Co}$ & $27059.66 \mathrm{c}$ & \multirow[t]{5}{*}{ Plutonium } & ${ }^{238} \mathrm{Pu}$ & $94238.66 \mathrm{c}$ \\
\hline \multirow[t]{5}{*}{ Nickel } & ${ }^{58} \mathrm{Ni}$ & $28058.62 \mathrm{c}$ & & ${ }^{239} \mathrm{Pu}$ & $94239.66 c$ \\
\hline & ${ }^{60} \mathrm{Ni}$ & $28060.62 \mathrm{c}$ & & ${ }^{240} \mathrm{Pu}$ & $94240.66 c$ \\
\hline & ${ }^{61} \mathrm{Ni}$ & $28061.62 \mathrm{c}$ & & ${ }^{241} \mathrm{Pu}$ & $94241.66 \mathrm{c}$ \\
\hline & ${ }^{62} \mathrm{Ni}$ & $28062.62 \mathrm{c}$ & & ${ }^{242} \mathrm{Pu}$ & $94242.66 \mathrm{c}$ \\
\hline & ${ }^{64} \mathrm{Ni}$ & $28064.62 c$ & \multirow[t]{4}{*}{ Americium } & ${ }^{241} \mathrm{Am}$ & $95241.66 \mathrm{c}$ \\
\hline Zirconium & $\mathrm{Zr}$ (natural) & $40000.66 \mathrm{c}$ & & ${ }^{242 \mathrm{~m}} \mathrm{Am}$ & $95242.66 \mathrm{c}$ \\
\hline \multirow[t]{2}{*}{ Molybdenum } & Mo (natural) & $42000.66 c$ & & ${ }^{243} \mathrm{Am}$ & $95243.66 \mathrm{c}$ \\
\hline & ${ }^{95} \mathrm{Mo}$ & $42095.50 \mathrm{c}$ & & & \\
\hline
\end{tabular}

${ }^{a}$ ZAID $=$ MCNP data table identifier.

The CSAS25 sequence of SCALE, which is also routinely used for criticality safety applications and accepted by the NRC for such purposes, was used to perform extensive independent verification calculations. These independent calculations provide considerable additional confidence in the MCNP modeling and results. CSAS25/KENO V.a was also used as a component of TSUNAMI-3D S/U analysis. The comparisons of MCNP and CSAS25/KENO results provide confidence in the modeling consistency, which is important to obtaining appropriate sensitivity coefficients that are used to assess the applicability of experiments to validation of the applications (PWR and BWR waste packages). The CSAS25 sequence calls functional modules BONAMI, CENTRM/PMC, and KENO V.a to automate cross-section processing and criticality calculations. BONAMI performs resonance self-shielding of the cross sections 
in the unresolved energy range for nuclides that have Bondarenko factors. CENTRM calculates fluxes using point-wise cross sections in the one-dimensional transport equation, and PMC generates fluxweighted multi-group cross sections for use in the KENO V.a calculation. Effective multiplication factors $\left(k_{e f f}\right)$ of the configurations are then calculated by using the three-dimensional, multi-group Monte Carlo code KENO V.a. All calculations supporting the validation in this report used the 238-energy-group library that is based on ENDF/B-VI data, except for the Crystal River CRC calculations that used the SCALE 238-energy-group library based on ENDF/B-V data (see Section 6.4.2). The 238-group library has 148 fast and 90 thermal groups below $3 \mathrm{eV}$. The MCNP and SCALE5.1/CSAS25 $k_{\text {eff }}$ results and the energy of average lethargy of fission (EALF) values for the application systems considered in the validation are presented in Table 16. The SCALE5.1/CSAS25 and MCNP $k_{\text {eff }}$ results are in very good agreement (all values within $0.3 \%$ ), which demonstrates consistency for material composition specification and geometry modeling between MCNP and CSAS25/KENO V.a calculation inputs as well as consistency in the underlying physics modeling and data. Figures 5 and 6 present a horizontal cross section of the MCNP models for the 21-PWR and 44-BWR waste packages, respectively.

Table 16. Criticality calculation results for 21-PWR and 44-BWR waste packages

\begin{tabular}{|c|c|c|c|c|c|c|c|c|c|}
\hline \multicolumn{2}{|c|}{ Application system } & \multicolumn{4}{|c|}{$\mathbf{M C N P}^{a}$} & \multicolumn{4}{|c|}{ SCALE5.1/ CSAS25 $^{b}$} \\
\hline $\begin{array}{c}\text { Waste } \\
\text { package }\end{array}$ & $\begin{array}{c}\text { Enrichment } \\
\left(\text { wt } \%{ }^{235} \mathrm{U}\right) / \\
\text { burnup } \\
\text { (GWd/MTU) }\end{array}$ & $\begin{array}{l}\text { Output } \\
\text { file }\end{array}$ & $\boldsymbol{k}_{\text {eff }}$ & $\sigma$ & $\begin{array}{c}E A L F^{c} \\
(\mathbf{e V})\end{array}$ & $\begin{array}{l}\text { Output } \\
\text { file }\end{array}$ & $\boldsymbol{k}_{\text {eff }}$ & $\sigma$ & $\begin{array}{c}E A L F^{c} \\
(\mathrm{eV})\end{array}$ \\
\hline \multirow{7}{*}{$\begin{array}{l}21 \text { PWR } \\
\text { nominal } \\
\text { configuration }\end{array}$} & $2.0 / 0$ & omb2-0 & 0.94348 & 0.00012 & $2.00 \mathrm{E}-01$ & $\mathrm{sb} 2-0$ & 0.94093 & 0.00016 & $1.97 \mathrm{E}-01$ \\
\hline & $3.0 / 0$ & omb3-0 & 1.05473 & 0.00013 & 2.34E-01 & sb3-0 & 1.05179 & 0.00018 & $2.31 \mathrm{E}-01$ \\
\hline & $3.0 / 15$ & omb15 & 0.94523 & 0.00012 & $3.21 \mathrm{E}-01$ & $\mathrm{sb} 15$ & 0.94328 & 0.00016 & $3.16 \mathrm{E}-01$ \\
\hline & $3.5 / 25$ & omb25 & 0.92654 & 0.00013 & $3.62 \mathrm{E}-01$ & $\mathrm{sb} 25$ & 0.92425 & 0.00018 & $3.57 \mathrm{E}-01$ \\
\hline & $4.0 / 30$ & omb30 & 0.93117 & 0.00013 & $3.89 \mathrm{E}-01$ & $\operatorname{sb} 30$ & 0.92884 & 0.00017 & $3.84 \mathrm{E}-01$ \\
\hline & $4.5 / 35$ & omb35 & 0.93142 & 0.00013 & 4.19E-01 & $\operatorname{sb} 35$ & 0.92898 & 0.00016 & 4.13E-01 \\
\hline & $5.0 / 40$ & omb40 & 0.93700 & 0.00013 & 4.42E-01 & $\mathrm{sb} 40$ & 0.93504 & 0.00018 & $4.36 \mathrm{E}-01$ \\
\hline \multirow{7}{*}{$\begin{array}{l}21 \text { PWR } \\
\text { design-basis } \\
\text { configuration }\end{array}$} & $2.0 / 0$ & omt2-0 & 0.97026 & 0.00011 & $1.96 \mathrm{E}-01$ & st2-0 & 0.96752 & 0.00015 & $1.94 \mathrm{E}-01$ \\
\hline & $3.0 / 0$ & omt3-0 & 1.08432 & 0.00013 & $2.30 \mathrm{E}-01$ & st3-0 & 1.08172 & 0.00017 & 2.27E-01 \\
\hline & $3.0 / 15$ & omt15 & 0.97166 & 0.00012 & $3.16 \mathrm{E}-01$ & st15 & 0.96919 & 0.00018 & $3.11 \mathrm{E}-01$ \\
\hline & $3.5 / 25$ & omt25 & 0.95197 & 0.00013 & $3.56 \mathrm{E}-01$ & st25 & 0.94972 & 0.00017 & $3.51 \mathrm{E}-01$ \\
\hline & $4.0 / 30$ & omt30 & 0.95662 & 0.00013 & $3.82 \mathrm{E}-01$ & st30 & 0.95407 & 0.00018 & $3.77 \mathrm{E}-01$ \\
\hline & $4.5 / 35$ & omt35 & 0.95717 & 0.00012 & 4.10E-01 & st35 & 0.95467 & 0.00018 & 4.05E-01 \\
\hline & $5.0 / 40$ & omt40 & 0.96247 & 0.00013 & $4.35 \mathrm{E}-01$ & st 40 & 0.96027 & 0.00020 & $4.29 \mathrm{E}-01$ \\
\hline \multirow{5}{*}{$\begin{array}{l}44 \text { BWR } \\
\text { nominal } \\
\text { configuration }\end{array}$} & $3.0 / 0$ & omb3-0 & 0.84621 & 0.00013 & $2.91 \mathrm{E}-01$ & $\mathrm{sb} 3-0$ & 0.84568 & 0.00017 & $2.89 \mathrm{E}-01$ \\
\hline & $3.0 / 10$ & omb3-10 & 0.83446 & 0.00013 & $4.86 \mathrm{E}-01$ & sb3-10 & 0.83327 & 0.00018 & $4.81 \mathrm{E}-01$ \\
\hline & $4.0 / 0$ & omb4-0 & 0.90764 & 0.00014 & $3.42 \mathrm{E}-01$ & $\mathrm{sb} 4-0$ & 0.90685 & 0.00020 & $3.39 \mathrm{E}-01$ \\
\hline & $4.0 / 20$ & omb4-20 & 0.84049 & 0.00013 & $6.22 \mathrm{E}-01$ & sb4-20 & 0.83913 & 0.00015 & $6.14 \mathrm{E}-01$ \\
\hline & $5.0 / 30$ & omb5-30 & 0.83283 & 0.00013 & $7.17 \mathrm{E}-01$ & $\mathrm{sb} 5-30$ & 0.83215 & 0.00016 & $7.07 \mathrm{E}-01$ \\
\hline \multirow{5}{*}{$\begin{array}{l}44 \text { BWR } \\
\text { design-basis } \\
\text { configuration }\end{array}$} & $3.0 / 0$ & omt3-0 & 0.88991 & 0.00013 & $2.77 \mathrm{E}-01$ & st3-0 & 0.88934 & 0.00018 & $2.75 \mathrm{E}-01$ \\
\hline & $3.0 / 10$ & omt3-10 & 0.87683 & 0.00013 & $4.60 \mathrm{E}-01$ & st3-10 & 0.87549 & 0.00015 & $4.54 \mathrm{E}-01$ \\
\hline & $4.0 / 0$ & omt4-0 & 0.95391 & 0.00014 & $3.25 \mathrm{E}-01$ & st4-0 & 0.95379 & 0.00018 & $3.22 \mathrm{E}-01$ \\
\hline & $4.0 / 20$ & omt4-20 & 0.88261 & 0.00013 & $5.88 \mathrm{E}-01$ & st4-20 & 0.88099 & 0.00018 & $5.81 \mathrm{E}-01$ \\
\hline & $5.0 / 30$ & omt5-30 & 0.87476 & 0.00013 & $6.75 \mathrm{E}-01$ & st5-30 & 0.87313 & 0.00017 & $6.68 \mathrm{E}-01$ \\
\hline
\end{tabular}

${ }^{a} \mathrm{MCNP}$ input and output files are included in the DVD attachment, paths: /DVD/apps/21 pwr/mcnp and /DVD/apps/44bwr/mcnp. The name of an output file was obtained by adding the character "o" in front of an input file name (e.g., mb15 is an input file and omb15 is its corresponding output file).

${ }^{b}$ SCALE/CSAS25 input and output files are included in the DVD attachment, paths /DVD/apps/21pwr/scale and

/DVD/apps/44bwr/scale. The CSAS25 input and output files have the extension inp and output, respectively (e.g., sb25.inp is an input file and sb25.output is its corresponding output file).

${ }^{c}$ energy of average lethargy of fission. 


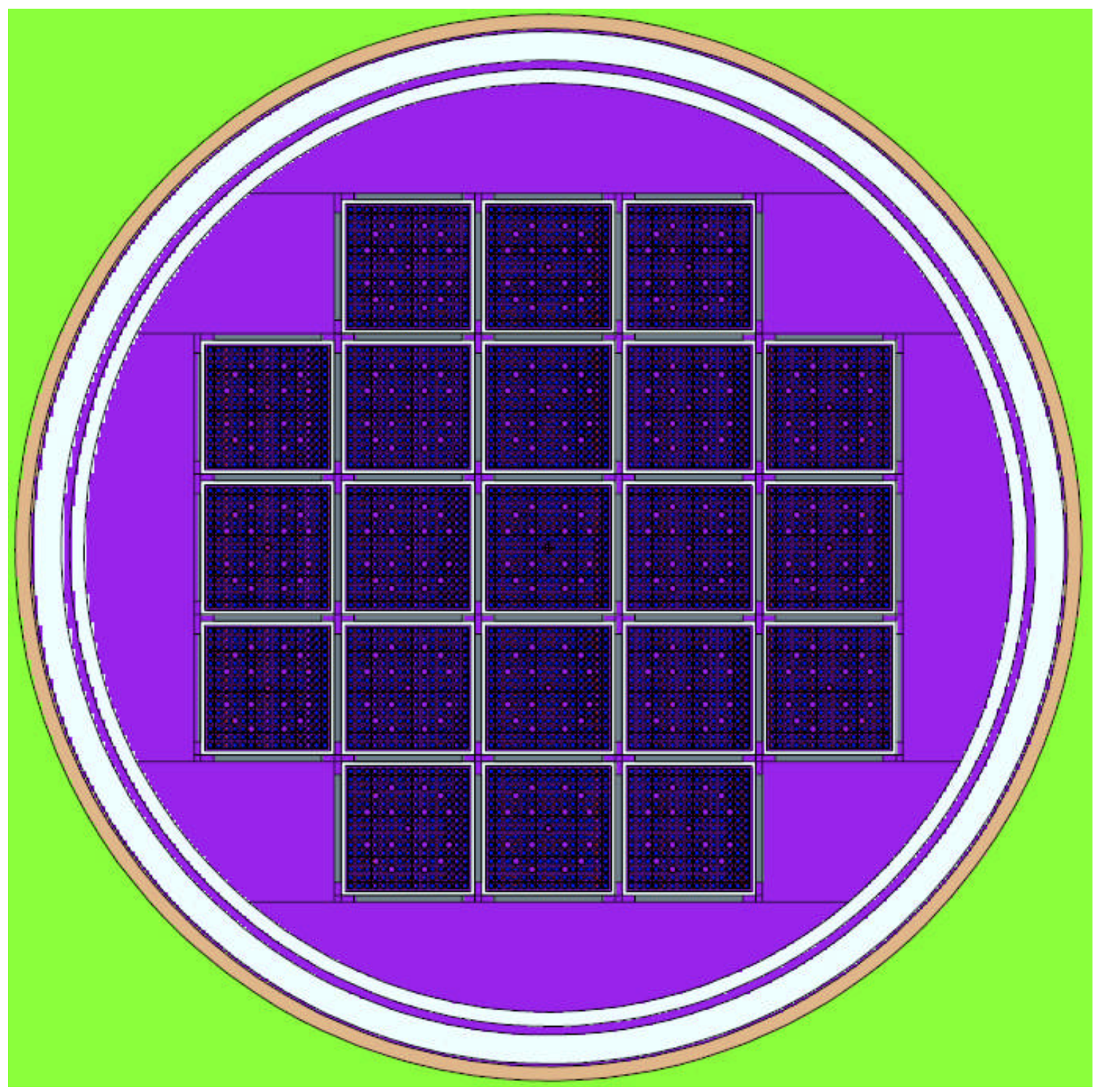

Fig. 5. Horizontal cross section of the MCNP model for the 21-PWR waste package. 


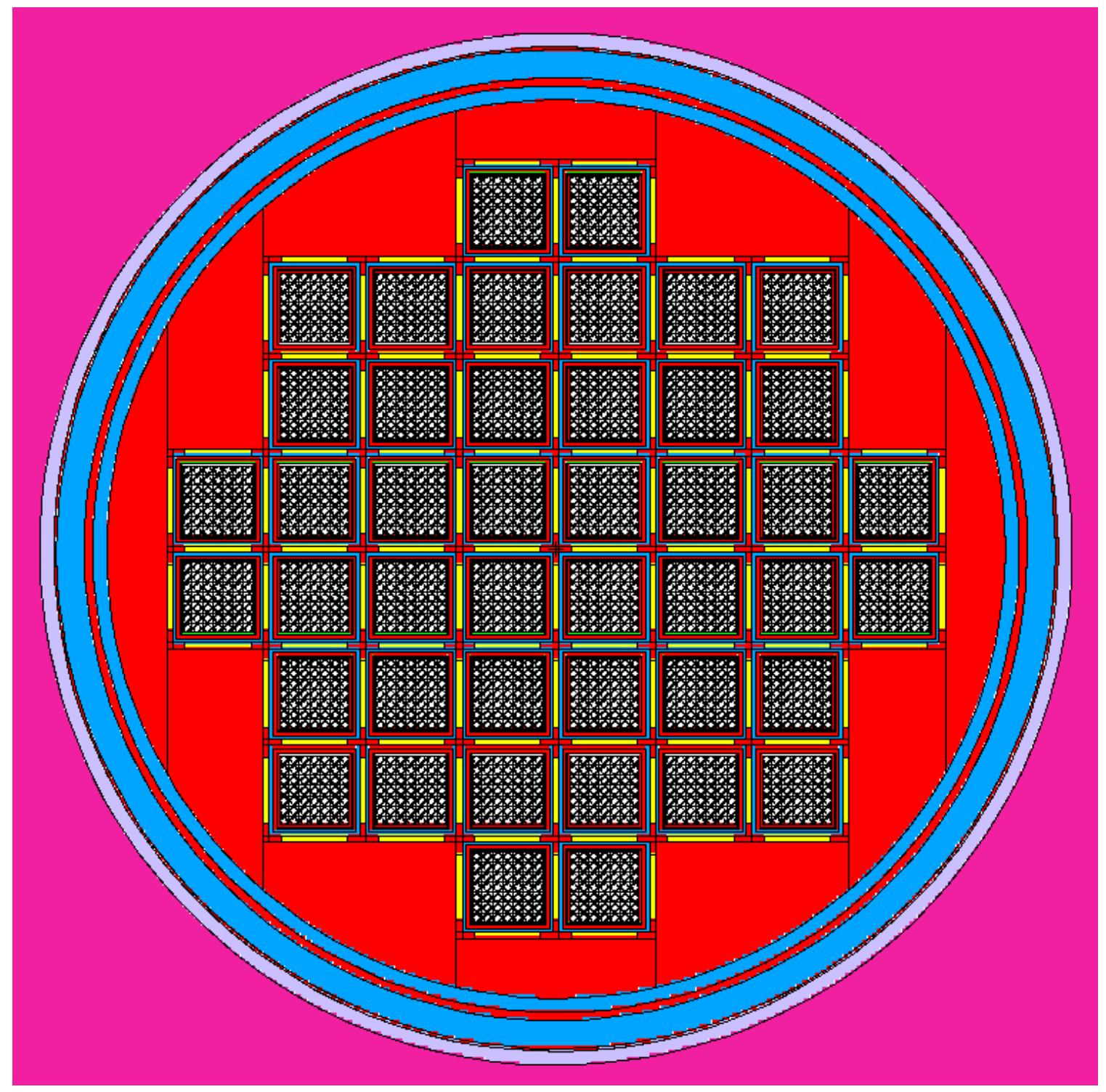

Fig. 6. Horizontal cross section of the MCNP model for the 44-BWR waste package. 


\subsection{SELECTION OF CRITICAL EXPERIMENTS FOR CONSIDERATION}

The accuracy of the computational method and cross-section data is established by evaluating critical experiments. The critical benchmarks selected as a component of this criticality validation consist of four different sets of critical experiments: public mixed-oxide $\left(\mathrm{PuO}_{2}\right.$ and $\left.\mathrm{UO}_{2}\right)(\mathrm{MOX})$ and low-enriched uranium (LEU) LCE data from the IHECSBE, proprietary HTC MOX LCE data, and CRCs (refer to Table 12 for the sources of critical experiment data). Selection of the critical experiments for consideration is based on similarities of physical characteristics between the application and experiment systems. A description of the selected critical experiments is provided in the following subsections. The selected critical experiments will be analyzed in Section 6.4 using the TSUNAMI methodology to identify the applicable critical experiments to criticality validation based on indices that quantify neutronic similarities between application and experiment systems.

\subsubsection{Public Laboratory Critical Experiments}

The source of LCEs is found in International Handbook of Evaluated Criticality Safety Benchmark Experiments ${ }^{45}$ from the OECD-NEA. The LCEs included in the validation methodology consist of moderated lattice configurations containing either mixed oxide fuel or low-enriched uranium dioxide fuel and MOX solutions. The selected MOX (52 cases) and LEU (37 cases) LCEs are listed in Sections 6.3.1.1 and 6.3.1.2, respectively. MCNP and CSAS25/KENO V.a modeling for the LCEs uses critical experiment descriptions available in the IHECSBE and produces results consistent with those reported in the handbook.

\subsubsection{MOX LCES}

The selection of MOX LCEs is based on physical characteristic similarities between CSNF waste packages and experiment systems. The 52 selected MOX critical experiments are water-moderated thermal systems containing either MOX in a lattice configuration or MOX solution. The MOX compound contains the isotopes ${ }^{234} \mathrm{U},{ }^{235} \mathrm{U},{ }^{236} \mathrm{U},{ }^{238} \mathrm{U},{ }^{238} \mathrm{Pu}$ through ${ }^{242} \mathrm{Pu}$, and ${ }^{241} \mathrm{Am}$.

MIX-COMP-THERM-002 Rectangular Arrays of Water-Moderated $\mathrm{UO}_{2}-2$ Wt. $\% \mathrm{PuO}_{2}\left(8 \%{ }^{240} \mathrm{Pu}\right)$ Fuel Rods. Cases 1 through 6.

MIX-COMP-THERM-003 Rectangular Arrays of Water-Moderated $\mathrm{UO}_{2}-6.6 \mathrm{Wt} \% \% \mathrm{PuO}_{2}$ Fuel Rods. Cases 1 through 6.

MIX-COMP-THERM-004 Critical Arrays of Mixed Plutonium-Uranium Fuel Rods with Water-to-Fuel Volume Ratios Ranging from 2.4 to 5.6. Case 1.

MIX-COMP-THERM-006 Water-Moderated Mixed Oxide Hexagonal Lattices - 2.0 Wt.\% $\mathrm{PuO}_{2}, 8 \%$

${ }^{240} \mathrm{Pu}$, Natural Uranium. Case 1.

MIX-COMP-THERM-007 Hexagonal Lattices of Mixed Oxide Fuel Pins $\mathrm{UO}_{2}-2$ Wt.\% $\mathrm{PuO}_{2}(16 \%$

${ }^{240} \mathrm{Pu}$ ), Natural Uranium. Case 2.

MIX-COMP-THERM-008 Hexagonal Lattices of Mixed Oxide Fuel Pins $\mathrm{UO}_{2}-2$ Wt.\% $\mathrm{PuO}_{2}(24 \%$

${ }^{240} \mathrm{Pu}$ ), Natural Uranium. Cases 1 through 6. 
MIX-SOL-THERM-001 Criticality Experiments with Mixed Plutonium and Uranium Nitrate Solution at a Plutonium Fraction of 0.2 and 1.0 in Annular Cylindrical Geometry. Cases 1 through 6 and 8 through 13.

MIX-SOL-THERM-002 Criticality Experiments with Mixed Plutonium and Uranium Nitrate Solution at a Plutonium Fraction of 0.2 and 0.5 in Large Cylindrical Geometry. Cases 1 through 3.

MIX-SOL-THERM-004 Criticality Experiments with Mixed Plutonium and Uranium Nitrate Solution at a Plutonium Fraction of 0.4 in Small Cylindrical Geometry. Cases 1 through 9.

MIX-SOL-THERM-005 Criticality Experiments with Mixed Plutonium and Uranium Nitrate Solution at a Plutonium Fraction of 0.4 in Slab Geometry. Cases 1 through 7.

\subsubsection{LEU LCES}

The selection of LEU LCEs is based on physical characteristic similarities between fresh fuel waste packages and experiment systems. The 37 selected LEU critical experiments are water-moderated thermal systems containing LEU in a lattice configuration, where the LEU compound contains the isotopes ${ }^{234} \mathrm{U}$, ${ }^{235} \mathrm{U},{ }^{236} \mathrm{U},{ }^{238} \mathrm{U}$.

LEU-COMP-THERM-010 Critical Arrays of Water-Moderated U(4.31) $\mathrm{O}_{2}$ Fuel Rods Reflected by Two Lead, Uranium, or Steel Walls. Cases 5 and 16 through 19.

LEU-COMP-THERM-017 Critical Arrays of Water-Moderated U(2.35)O $\mathrm{O}_{2}$ Fuel Rods Reflected by Two Lead, Uranium, or Steel Walls. Cases 3 through 17, 19 through 25, 28, and 29.

LEU-COMP-THERM-026 Water-Moderated U(4.92) $\mathrm{O}_{2}$ Fuel Rods in 1.29, 1.09, and $1.01 \mathrm{~cm}$ Pitch Hexagonal Lattices at Different Temperatures. Case 3.

LEU-COMP-THERM-042 Water-Moderated Rectangular Clusters Of U(2.35) $\mathrm{O}_{2}$ Fuel Rods (1.684 cm Pitch) Separated By Steel, Boral, Boroflex, Cadmium, Or Copper Plates With Steel Reflecting Walls. Cases 1 through 7.

\subsubsection{Proprietary LCE Data-Haut Taux de Combustion Laboratory Critical Experiments}

In the late 1980s, a series of critical experiments referred to as the HTC experiments were conducted at the experimental criticality facility in Valduc, France. These experiments were designed to provide a basis for validation of actinide-only burnup credit calculations. The simulated fuel rods used in these experiments contained a mixture of uranium and plutonium oxides. The plutonium-to-uranium ratio and the isotopic compositions of both the uranium and plutonium were designed to be similar to what would be found in a typical PWR fuel assembly that initially had an enrichment of $4.5 \mathrm{wt} \%{ }^{235} \mathrm{U}$ and was burned to $37,500 \mathrm{MWd} / \mathrm{MTU}$. The fuel material includes ${ }^{234} \mathrm{U},{ }^{235} \mathrm{U},{ }^{236} \mathrm{U},{ }^{238} \mathrm{U},{ }^{238} \mathrm{Pu}$ through ${ }^{242} \mathrm{Pu}$, and ${ }^{241} \mathrm{Am}$, which is present due to the decay of ${ }^{241} \mathrm{Pu}$.

The 156 critical configurations were designed to approximate fuel handling, fuel storage rack, and spent fuel shipping cask conditions and were categorized into four phases. ${ }^{46}$ The first phase ${ }^{47}$ included 18 configurations, each involving a single square-pitched array of rods with rod pitch varying from 1.3 to $2.3 \mathrm{~cm}$. The arrays were flooded and reflected with clean water. The second phase ${ }^{48}$ included 41 configurations that were similar to the first group except that the water used as moderator and reflector included either boron or gadolinium in solution. The third phase ${ }^{49}$ simulated fuel-assembly storage rack conditions included 26 configurations with the rods arranged into four assemblies in a $2 \times 2$ array. The 
spacing between assemblies was varied, and some of the assemblies had borated stainless steel (which is used in the waste package), Boral ${ }^{\circledR}$, or cadmium plates attached to the sides of the four assemblies. The fourth phase ${ }^{50}$ simulated cask conditions and included 71 configurations similar to the Phase 3 configurations except thick steel or lead shields were placed around the outside of the $2 \times 2$ array of fuel assemblies. A total of 156 configurations are documented in the final reports, and a total of 145 configurations are used in this validation. The following HTC LCE cases are not well defined in the documented reports and therefore were not used in this validation: HTC Phase 3, cases 2, 6, and 8; HTC Phase 4, lead shield, cases 1, 12,13,14, and 17; and HTC Phase 4, steel shield, cases 1, 12, and 14. The results of the criticality calculations are presented in Appendix A, Table A-1. These data were selected because they were specifically developed for this use, that is, validation of criticality methods for burnup credit, and have been shown in previous studies (Ref. 68) to have excellent applicability to CSNF applications.

\subsubsection{Commercial Reactor Criticals}

The CRCs are the only critical experiments that include actual spent nuclear fuel representative of the waste stream assemblies. In fact, the assemblies in the CRCs are part of the waste stream. The CRCs included as a component of the validation methodology are comprised of 45 critical state-points from five PWRs: Crystal River Unit 3 (33 configurations), McGuire Unit 1 (six configurations), Sequoyah Unit 2 (three configurations), and Three Mile Island (TMI) Unit 1 (three configurations), and 16 state-points from BWR Grand Gulf Unit 1. The CRC state-points used in this validation are reactor hot zero-power critical conditions attained after sufficient down time to allow the fission product xenon inventory to decay. The selection of the CRCs was based on the similar nuclear and physical characteristics between the application systems and the CRC state-points, including similar actinide and fission-product compositions. A number of studies have been previously carried out to demonstrate the suitability of CRCs as spent-fuel benchmark experiments and their applicability for criticality calculation validation. ${ }^{69}$, 70,71 These studies focused on general characteristic comparisons between the CRCs and waste packages and showed that, although a neutron spectral shift exists between the two systems due to various effects (e.g., moderator temperature differences and material differences), the CRCs closely represent the reaction rates in a waste package configuration.

The CRC state-point configurations were modeled in MCNP with fine details. Changes were made to the original MCNP input files to create new input files for MCNP 5.1.40 calculations with ENDF/B-VI data. The original input files used MCNP data tables based on the ENDF/B-V library (refer to Section 4.1.2.3 for the sources of the MCNP input files for the CRCs). Therefore, the MCNP input files were modified to replace data tables based on the ENDF/B-V library with data tables presented in Table 15 and additional ENDF/B-VI library data tables available in MCNP 5.1.40. An additional change made to the original MCNP files for the MCNP 4B version (Ref. 53) for one-eighth symmetry CRC models was replacement of the geometry cutting plane that defines a one-eighth symmetry core model with a cutting plane that defines a one-fourth symmetry core model. Note that the modeling for a one-fourth symmetry core was already implemented in the original MCNP input files for these cases. The $k_{\text {eff }}$ results for one-fourth symmetry geometry and the $k_{\text {eff }}$ results for the one-eight symmetry geometry provided in Ref. 52 are almost identical, as shown in Table D-1, Appendix D, which indicate that the two MCNP core models are identical.

Consistent with the MCNP modeling, CSAS25/KENO V.a modeling was performed for Crystal River Unit 3 CRC state-points for use in TSUNAMI-3D calculations. The input data for these models were extracted from the MCNP 4B input files (Ref. 53) and reactor core descriptions available in Ref. 52, and the CSAS25/KENO V.a models have the same geometry and material description details as the MCNP models. Spent fuel zone compositions contain oxygen and up to 85 actinide and fission-product isotopes (Ref. 52), since short-lived fission products have relevant reactivity worth in the CRCs. A horizontal and 
a partial vertical cross section of the KENO V.a geometry for a Crystal River state-point is illustrated in Fig. 7. The verification of the CSAS25/KENO V.a models was made though comparison between the MCNP 4B $k_{\text {eff }}$ results (Ref. 52) and CSAS25 $k_{\text {eff }}$ results, which are presented in Table D-2, Appendix D. Generally, the CSAS25 $k_{\text {eff }}$ results are in good agreement with the results described in the referenced document $( \pm 0.3 \%)$, indicating that the mixture compositions and geometry models are consistent between the CSAS25 and MCNP calculations. Only the results for the last two Crystal River state-points are significantly lower than the corresponding MCNP calculation results. However, the impact on sensitivity coefficients is expected to be less important because these coefficients are defined in terms of relative values (see Appendix B).

The results of the MCNP calculations with ENDF/B-VI data for the $61 \mathrm{CRC}$ state-points are presented in Appendix A, Table A-4. As was observed in the previous analysis (Ref. 60) of the Grand Gulf statepoints, a significant deviation from unity was obtained for CRC Grand Gulf state-point $20\left(k_{\text {eff }}=0.9681\right)$. This value is also significantly different from the $k_{\text {eff }}$ results for Grand Gulf state-points with similar average core burnup, such as state-points $15\left(k_{\text {eff }}=0.9816\right)$ and $19\left(k_{\text {eff }}=0.9803\right)$ (see Appendix A, Table A-4). Therefore, the Grand Gulf state-point 20 was not used in bias and bias uncertainty determination.

All critical experiment configurations have some quantity of uncertainty. For this reason, evaluations of critical experiments included in the IHECSBE include an assessment of the experimental uncertainties, which for LCE are typically quite small, for example, less than $\sim 0.3 \%$ in $k_{\text {eff. }}$ For CRC state-points, which are large and complex systems, it is recognized that larger uncertainties are expected to exist, as compared to LCEs. Although a detailed assessment of the uncertainties in these configurations has not been performed to accurately quantify the uncertainty in these configurations, a qualitative assessment has been performed to assign a justifiable upper bound (conservative) uncertainty value to be used in this analysis. An uncertainty of 2\% (two standard deviations at 95\% confidence level) for CRC $k_{\text {eff }}$ values is used in statistical analyses for bias and bias uncertainty determination presented in Section 6.5.2. The rationale for selecting this uncertainty value is as follows:

- A statistically significant number of CRC state-points (61) were selected as a component of this validation methodology. The MCNP 5.1.40 $k_{\text {eff }}$ values for all selected CRCs but one (Grand Gulf state-point 20) (see Appendix A, Table A-4) are contained within unity $\pm 2 \%$. The statistical distributions of the $k_{\text {eff }}$ values for the PWR and BWR CRCs pass a normality test. Figure D-1, Appendix D, shows a distribution histogram plot for PWR and BWR (Grand Gulf) CRC $k_{\text {eff }}$ values. The sample standard deviation for the applicable PWR CRC and BWR (Grand Gulf) $k_{\text {eff }}$ values is approximately 0.005 , which is smaller than the assumed $1 \%$ one standard deviation in calculated $k_{\text {eff }}$ values due to modeling uncertainties.

- CRC $k_{\text {eff }}$ values exhibit an increasing or decreasing trend as a function of parameters burnup, EALF, and integral index $c_{k}$ (refer to Appendix B for the definition and meaning of the integral index $c_{k}$ ) that can be distinguished from random behavior.

- The statistical method used to determine bias and bias uncertainty ${ }^{18}$ also quantifies uncertainties associated with any modeling approximations and uncertainties in the experimental conditions as reflected in the random scatter of the data points about the bias, since the CRC $k_{\text {eff }}$ values satisfy the required statistical behavior.

- Bias (and bias uncertainty) associated with the isotopic compositions are evaluated separately (Ref. 72), as described in Section 3.5.3.1 of the Disposal Criticality Analysis Methodology Topical Report, ${ }^{1}$ and combined with the bias determined for the criticality computational method (determined 
in this report) as if they were independent variables (Ref. 1, Section 3.5.3.2.5). In reality, these two bias components are not independent since any isotopic composition bias will propagate to the criticality calculation results. Therefore, this approach determines conservative bias and uncertainty associated with the bias. 

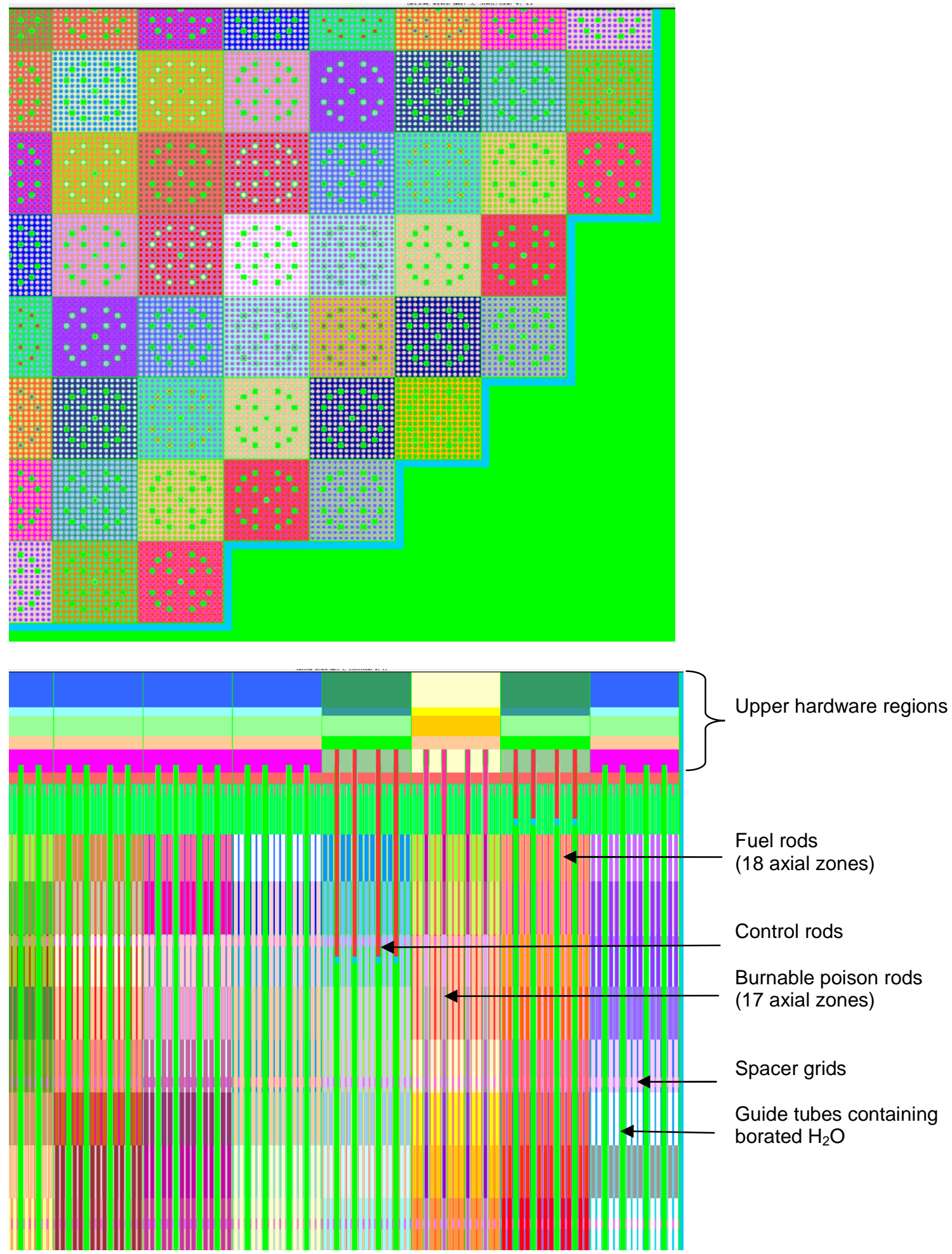

Fig. 7. Horizontal and partial vertical cross sections of KENO V.a geometry for a Crystal River Unit 3 state-point. 


\subsection{DETERMINATION OF APPLICABILITY OF CRITICAL EXPERIMENTS}

Sensitivity/uncertainty analysis methods can be used to demonstrate that nuclear systems with similar physical characteristics, including material compositions, geometry, and neutron flux spectra, exhibit similar sensitivities of the effective neutron multiplication factor, $k_{\text {eff }}$, to perturbations in the neutron cross-section data on an energy-dependent, nuclide-reaction specific level. The assessment of system similarities and shared variance, due to cross-section uncertainties, in the computed values of $k_{e f f}$ is particularly useful in determining applicability of critical experiments to be used to determine bias and bias uncertainty of criticality safety calculations. Scientists at ORNL have formulated the theoretical bases for use of $\mathrm{S} / \mathrm{U}$ analysis methods in criticality safety validation and developed the software tools needed to implement the methodology in the SCALE code system. ${ }^{15,16} \mathrm{~A}$ set of indices has been defined for use in $\mathrm{S} / \mathrm{U}$ analyses that provides a measure of the neutronic similarity between a design system and a critical experiment. Integral index $c_{k}$ is the correlation coefficient between sensitivity-weighted uncertainties in the application system and an experiment system. A $c_{k}$ value of 0.0 represents no correlation between the systems, a value of 1.0 represents full correlation between the systems, that is, indicates identical systems, and a value of -1.0 represents a full anticorrelation. The definition of integral index $c_{k}$, the parameter used in this methodology to identify applicable critical experiments for use in bias and bias uncertainty determination, is provided in Appendix B. Reference 63 demonstrates that $c_{k}$ values of 0.80 or higher constitute systems that are similar to the extent that they are useful in the determination of bias and associated uncertainty. Further, Ref. 63 recommends that the validation methodology should include about 15 to 20 very correlated systems ( $c_{k}$ of 0.90 or higher) or 25 to 40 moderately correlated systems ( $c_{k}$ of 0.80 or higher). This validation uses this published guidance; that is, a critical configuration is applicable to an evaluation case if the $c_{k}$ value is $\geq 0.9$, a critical configuration is considered marginally applicable if $c_{k}$ is $\geq 0.8$ and $<0.9$, and a critical configuration is considered not applicable if $c_{k}<0.8$.

\subsubsection{Methods}

Although the objective of this work is validating MCNP, MCNP does not have an S/U capability. Hence, the sensitivity/uncertainty analysis was performed with the TSUNAMI-3D sequence and the TSUNAMIIP module distributed as part of the SCALE 5.1 package, and was used to quantify the applicability of the experiments for the determination of the LBTL. TSUNAMI-3D is a Monte Carlo - based eigenvalue sensitivity analysis sequence. This software tool calculates energy-, mixture-, nuclide-, and regiondependent sensitivity of the system $k_{\text {eff }}$ to variations in nuclear data of modeled materials. TSUNAMI-3D uses first-order linear-perturbation theory to calculate sensitivity coefficients (refer to Appendix B for the definition of sensitivity coefficients). The functional modules executed by the TSUNAMI-3D sequence for the calculations presented in this report are BONAMIST, CENTRMST/PMCST/WORKER or NITAWLST, KENO V.a, and SAMS. The functional modules BONAMIST, NITAWLST, and CENTRMST/PMCST/WORKER perform resonance processing of the cross sections. KENO V.a performs forward and adjoint Monte Carlo calculations using the resonance-processed cross sections, and SAMS uses the forward and adjoint solutions in a standard linear perturbation theory method to calculate neutron energy-dependent sensitivity profiles. The profiles for each modeled system are saved in a sensitivity data file (SDF). CENTRMST/PMCST/WORKER and the SCALE ENDF/B-VI 238-group cross-section library were used in cross-section resonance processing for all cases except for the CRC calculations, which used NITAWLST and the SCALE ENDF/B-V 238-group cross-section library (see Section 6.4.2). To increase confidence that the sensitivity profiles are accurate, selected direct perturbation calculations were performed. Appendix $\mathrm{C}$ describes the direct perturbation method used to verify that the TSUNAMI-3D calculated sensitivity coefficient values are consistent with the sensitivity coefficients that MCNP would estimate. As implemented in the TSUNAMI tools, sensitivity is the fractional change in the $k_{\text {eff }}$ value resulting from a fractional change in the nuclear data parameter of 
interest. For example, if the capture sensitivity for ${ }^{10} \mathrm{~B}$ in a model is -0.1 , then a $1 \%$ increase in the capture cross sections would result in a $0.1 \%$ reduction in the system $k_{\text {eff }}$ value.

TSUNAMI-IP, also a part of the SCALE 5.1 computer software package, is used to compare the sensitivity data for two systems. It generates a variety of total and partial relational parameters that quantify the similarity between two systems. The integral index $c_{k}$ (refer to Appendix $\mathrm{B}$ for the definition of $c_{k}$ ) is a single-valued parameter used to assess similarity of nuclear data uncertainty-weighted sensitivity profiles for all nuclide-reactions between a design system and a criticality experiment. A $c_{k}$ value of 0.0 represents no correlation between the systems, a value of 1.0 represents full correlation between the systems, that is, indicates identical systems, and a value of -1.0 represents a full anticorrelation. The premise behind the $c_{k}$ parameter is that calculation biases are due primarily to errors in cross-section data with larger uncertainties. Systems that demonstrate similarly high sensitivities to highly uncertain cross-section data will have similar computational biases. The similarity work presented in this report utilizes the $c_{k}$ parameter.

\subsubsection{TSUNAMI-3D and TSUNAMI-IP Calculations}

The results of the TSUNAMI-IP calculations are presented in Appendix B. Tables B-1 through B-12 show the $c_{k}$ values for each of the 24 application systems (refer to Table 16) and each set of critical experiments. All critical experiments with $c_{k} \geq 0.8$ are considered marginally applicable. Table 17 provides the number of applicable critical experiments to bias and bias determination, that is, critical experiments with $c_{k} \geq 0.8$, for each of the 24 application systems. Cell shading was used in Tables B-1 through B-12 to identify these applicable critical experiments. More than 40 marginally applicable critical experiments that also include at least 15 to 20 very correlated systems ( $c_{k}$ of 0.90 or higher), as recommended in Ref. 63, are available for bias and bias uncertainty determination for all application systems except for the fresh fuel waste packages. For these systems, only the LEU LCEs and fresh fuel CRCs are at least marginally applicable among the selected critical experiments. Between 41 and 43 LCEs and fresh-fuel CRCs are at least marginally applicable to the fresh fuel PWR and BWR applications due to similar sensitivities to ${ }^{1} \mathrm{H},{ }^{235} \mathrm{U}$, and ${ }^{238} \mathrm{U}$, which are the predominant contributors to $\mathrm{c}_{\mathrm{k}}$ for the fresh fuel systems. The HTC and MOX LCEs and CRCs with burned fuel were not applicable to these systems due primarily to the presence of plutonium.

The LEU LCEs and the fresh fuel CRCs are most neutronically similar to fresh fuel waste packages because their $k_{\text {eff }}$ values exhibit significant sensitivities only to ${ }^{1} \mathrm{H},{ }^{235} \mathrm{U}$, and ${ }^{238} \mathrm{U}$, that is, these experiments and the fresh fuel waste packages have common components of uncertainty in $k_{\text {eff }}$ due to cross-section uncertainties for those nuclides.

Only sensitivity data files for the Crystal River state-points are available for assessing similarity between a CRC state-point and the application systems. These Crystal River CRC sensitivity files were obtained with a non-qualified version of SCALE 5.1 and the 238-group ENDF/B-V SCALE library and NITAWL for resonance-cross section processing, as described in Refs. 73 and 74. To reduce the computer time of a TSUNAMI-3D calculation for a Crystal River state-point, the total number of nuclides in KENO V.a fuel mixtures was reduced from more than 40,000 to approximately 20,000 by including in fuel compositions only the actinides and the major fission products that have been identified as being important to burnup credit criticality calculations (see Sect. 6.1). While this approach significantly reduced the required computer time, it had minimal effects on the accuracy of the sensitivity coefficients because these coefficients are defined in terms of relative values. Note that sensitivity data for Crystal River state-points is used only to determine the applicability of the CRCs considered in this validation and is not directly used in bias and bias uncertainty determination; therefore, use of the non-qualified Crystal River sensitivity files is adequate for this calculation. As shown in Tables B-10 through B-12, Appendix B, all Crystal River state-points, except for the beginning-of-life state-point, exhibit at least marginal similarity 
with the 21-PWR waste packages containing CSNF with burnup (that is, cases not based on fresh fuel) and the 44-BWR waste packages containing CSNF of $3-\mathrm{wt} \%{ }^{235} \mathrm{U}$ initial enrichment and $10 \mathrm{GWd} / \mathrm{MTU}$ burnup, whereas 27 Crystal River state-points (out of 33 state-points) exhibit at least marginal similarity with the other 44-BWR waste packages containing CSNF with burnup. Based on this observation, the state-points other than beginning of life state-points for the other CRCs considered in this validation are considered applicable to bias and bias uncertainty determination for the CSNF waste packages (that is, expected to have $c_{k}$ values $>0.8$ ).

Table 17. Summary of applicable critical experiments to bias and bias uncertainty determination

\begin{tabular}{|c|c|c|c|c|c|c|c|}
\hline \multicolumn{2}{|c|}{ Application system } & \multicolumn{6}{|c|}{ Number of applicable critical experiments } \\
\hline $\begin{array}{c}\text { Waste } \\
\text { package }\end{array}$ & $\begin{array}{c}\text { Enrichment } \\
\left(\text { wt } \%{ }^{235} \mathrm{U}\right) / \\
\text { burnup } \\
\text { (GWd/MTU) }\end{array}$ & $\begin{array}{l}\text { MOX } \\
\text { lattice }\end{array}$ & $\begin{array}{c}\text { MOX } \\
\text { solution }\end{array}$ & LEU & HTC & CRC & Total \\
\hline \multirow{7}{*}{$\begin{array}{l}21 \mathrm{PWR} \\
\text { nominal } \\
\text { configuration }\end{array}$} & $2.0 / 0$ & 0 & 0 & 37 & 0 & 4 & $41^{a}$ \\
\hline & $3.0 / 0$ & 0 & 0 & 37 & 1 & 5 & $43^{a}$ \\
\hline & $3.0 / 15$ & 17 & 0 & 0 & 145 & 56 & 218 \\
\hline & $3.5 / 25$ & 18 & 0 & 0 & 145 & 56 & 219 \\
\hline & $4.0 / 30$ & 18 & 1 & 0 & 145 & 56 & 220 \\
\hline & $4.5 / 35$ & 19 & 11 & 0 & 145 & 56 & 231 \\
\hline & $5.0 / 40$ & 18 & 1 & 0 & 145 & 56 & 220 \\
\hline \multirow{7}{*}{$\begin{array}{l}21 \text { PWR } \\
\text { design-basis } \\
\text { configuration }\end{array}$} & $2.0 / 0$ & 0 & 0 & 37 & 0 & 4 & $41^{a}$ \\
\hline & $3.0 / 0$ & 0 & 0 & 37 & 0 & 5 & $42^{a}$ \\
\hline & $3.0 / 15$ & 17 & 0 & 0 & 145 & 56 & 218 \\
\hline & $3.5 / 25$ & 18 & 0 & 0 & 145 & 56 & 219 \\
\hline & $4.0 / 30$ & 18 & 1 & 0 & 145 & 56 & 220 \\
\hline & $4.5 / 35$ & 19 & 2 & 0 & 145 & 56 & 222 \\
\hline & $5.0 / 40$ & 18 & 1 & 0 & 145 & 56 & 220 \\
\hline \multirow{5}{*}{$\begin{array}{l}44 \text { BWR } \\
\text { nominal } \\
\text { configuration }\end{array}$} & $3.0 / 0$ & 0 & 0 & 37 & 0 & 4 & $41^{a}$ \\
\hline & $3.0 / 10$ & 20 & 9 & 0 & 145 & 56 & 230 \\
\hline & $4.0 / 0$ & 0 & 0 & 37 & 0 & 4 & $41^{a}$ \\
\hline & $4.0 / 20$ & 21 & 17 & 0 & 145 & 51 & 234 \\
\hline & $5.0 / 30$ & 21 & 19 & 0 & 145 & 51 & 236 \\
\hline \multirow{5}{*}{$\begin{array}{l}44 \text { BWR } \\
\text { design-basis } \\
\text { configuration }\end{array}$} & $3.0 / 0$ & 0 & 0 & 37 & 0 & 4 & $41^{a}$ \\
\hline & $3.0 / 10$ & 19 & 9 & 0 & 145 & 56 & 229 \\
\hline & $4.0 / 0$ & 0 & 0 & 37 & 0 & 4 & $41^{a}$ \\
\hline & $4.0 / 20$ & 21 & 17 & 0 & 145 & 51 & 234 \\
\hline & $5.0 / 30$ & 21 & 21 & 0 & 145 & 51 & 238 \\
\hline
\end{tabular}

${ }^{a}$ Only the applicable LEU LCEs with EALF values below 0.3882 (36 LEU LCEs) were used to calculate the

LBTL values shown in Sections 6.5 and 7 since the EALF for the evaluated fresh fuel waste packages varies from $0.20 \mathrm{eV}$ to $0.33 \mathrm{eV}$.

Figures 8 through 13 show the $c_{k}$ values and illustrate the set of applicable critical experiments to bias and bias uncertainty determination for the 21-PWR waste packages containing CSNF of $3.0 \mathrm{wt} \%{ }^{235} \mathrm{U}$ and $15-\mathrm{GWd}$ /MTU burnup, CSNF of $5.0 \mathrm{wt} \%{ }^{235} \mathrm{U}$ and $40-\mathrm{GWd} / \mathrm{MTU}$ burnup, and fresh fuel of $3.0 \mathrm{wt} \%{ }^{235} \mathrm{U}$ initial enrichment, and the 44-BWR waste package containing CSNF of $3.0 \mathrm{wt} \%{ }^{235} \mathrm{U}$ and $10-\mathrm{GWd} / \mathrm{MTU}$ burnup, CSNF of $5.0 \mathrm{wt} \%{ }^{235} \mathrm{U}$ and $30-\mathrm{GWd} / \mathrm{MTU}$ burnup, and fresh fuel of $3.0 \mathrm{wt} \%{ }^{235} \mathrm{U}$ initial enrichment, respectively. The critical experiments with $c_{k}$ values above the red grid line, that is, $c_{k} \geq 0.8$, are at least marginally applicable, whereas the critical experiments with $c_{k}$ values above the green grid line, that is, $c_{k} \geq 0.9$, are highly applicable. Critical experiments with $c_{k}$ values $\geq 0.8$ are used in the bias determination. 
The direct perturbation method (refer to Appendix C for method description) is used to assess the quality of the sensitivity coefficients obtained in a TSUNAMI-3D calculation and provide confidence that sensitivities calculated by SCALE/TSUNAMI are consistent with what can be calculated with MCNP. Sensitivity coefficients from MCNP direct perturbation calculations were obtained for nuclides/elements for which $k_{\text {eff }}$ exhibits significant sensitivities, such as $\mathrm{H},{ }^{10} \mathrm{~B},{ }^{235} \mathrm{U},{ }^{238} \mathrm{U},{ }^{239} \mathrm{Pu}$, and ${ }^{149} \mathrm{Sm}$, in the waste package models. A comparison of direct perturbation and TSUNAMI-3D sensitivity coefficient calculations is presented in Table C-1, Appendix C. Note that the sensitivity coefficient estimates from the MCNP direct perturbation calculations have larger uncertainties than the TSUNAMI-3D sensitivity coefficients, although the estimated $k_{\text {eff }}$ from each individual MCNP calculation had a very small standard deviation (0.00012). The two methods are in good agreement since the MCNP direct perturbation results differ from the TSUNAMI-3D results by less than $\pm 10 \%$ for the majority of the calculations, with the rest of the direct perturbation calculations being within $\pm 20 \%$ of the TSUNAMI-3D results. These results provide confidence that sensitivities calculated by SCALE/TSUNAMI are consistent with what can be calculated with MCNP. Hence, it is acceptable to use TSUNAMI for assessing applicability of experiments that will be used to validate MCNP.

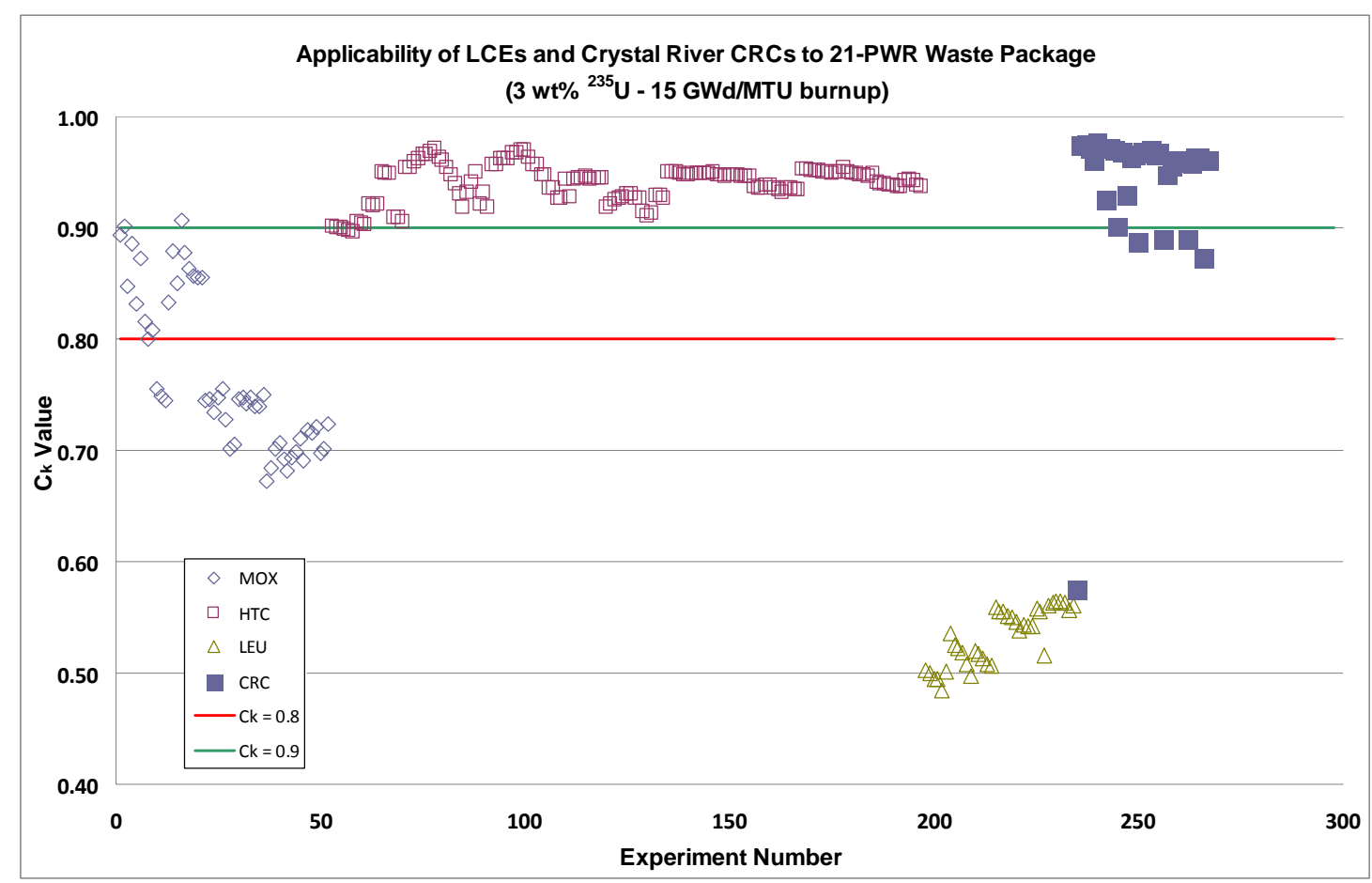

Fig. 8. $c_{k}$ as a function of experiment number: 21-PWR waste package, CSNF of 3 wt $\%{ }^{235} \mathrm{U}$ initial enrichment, and 15-GWd/MTU burnup. 


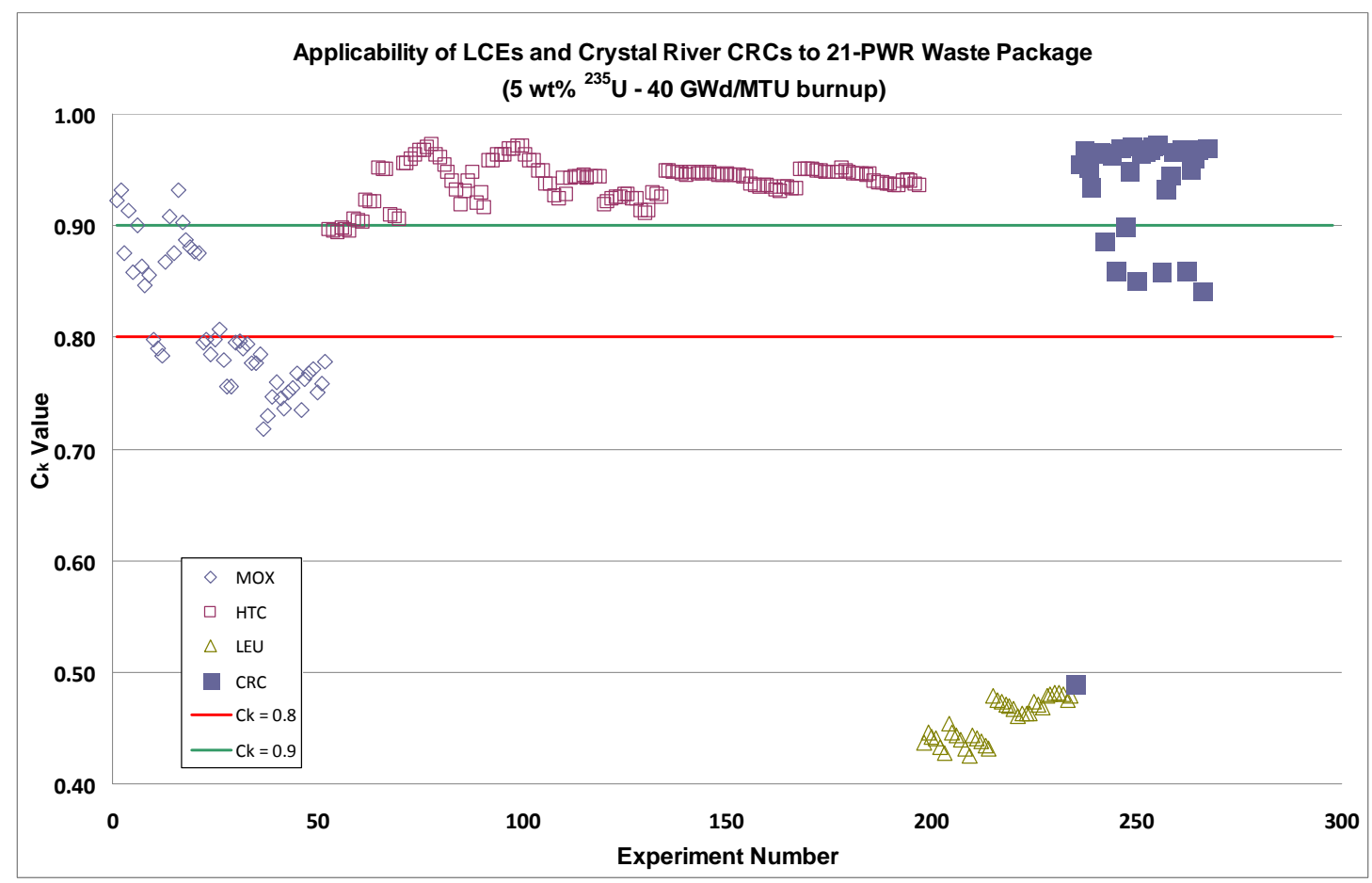

Fig. 9. $c_{k}$ as a function of experiment number: 21-PWR waste package, CSNF of $5 \mathrm{wt} \%{ }^{235} \mathrm{U}$ initial enrichment, and 40-GWd/MTU burnup.

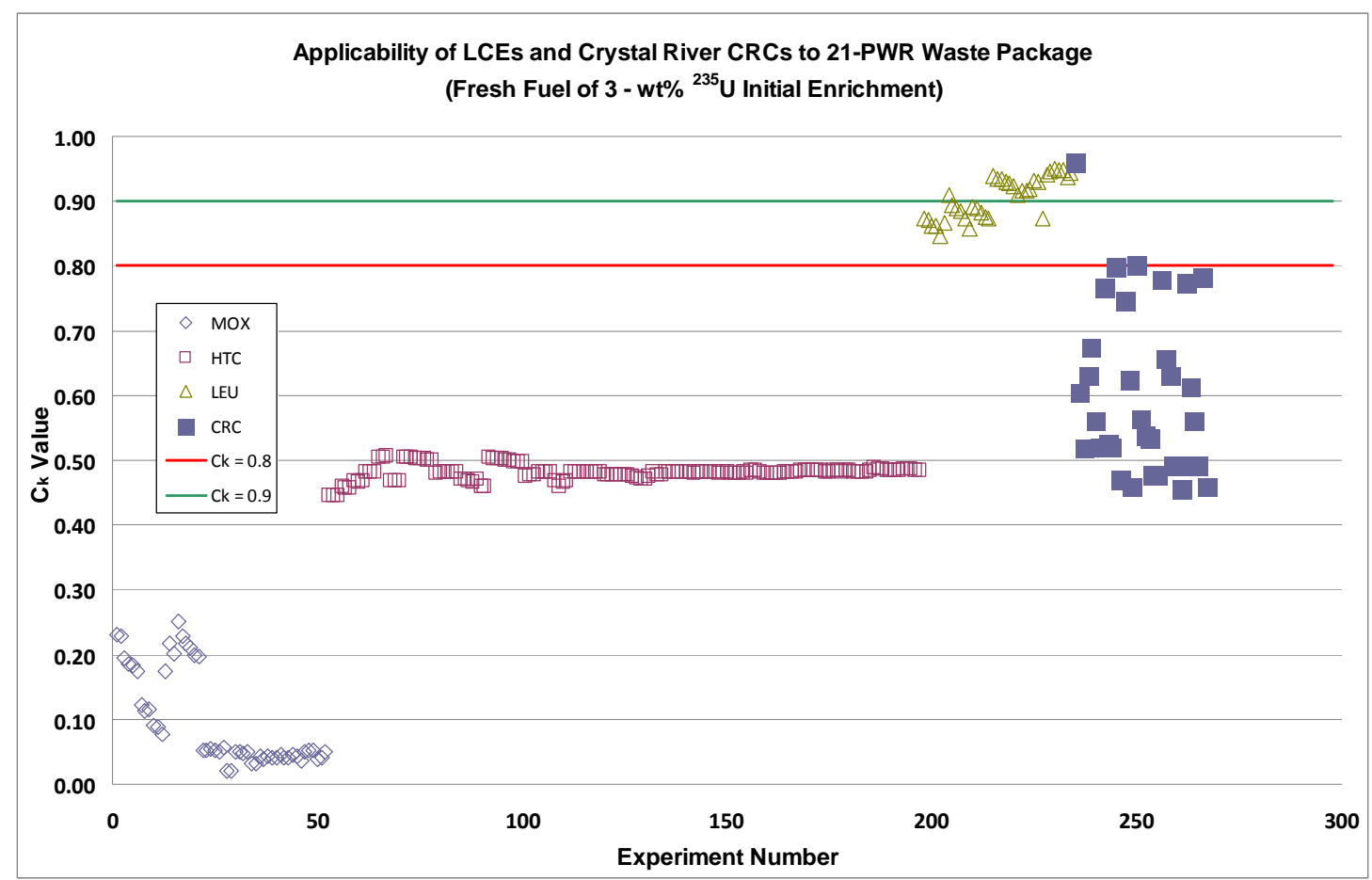

Fig. 10. $c_{k}$ as a function of experiment number: 21-PWR waste package, fresh fuel of $3 \mathrm{wt} \%{ }^{235} \mathrm{U}$ initial enrichment. 


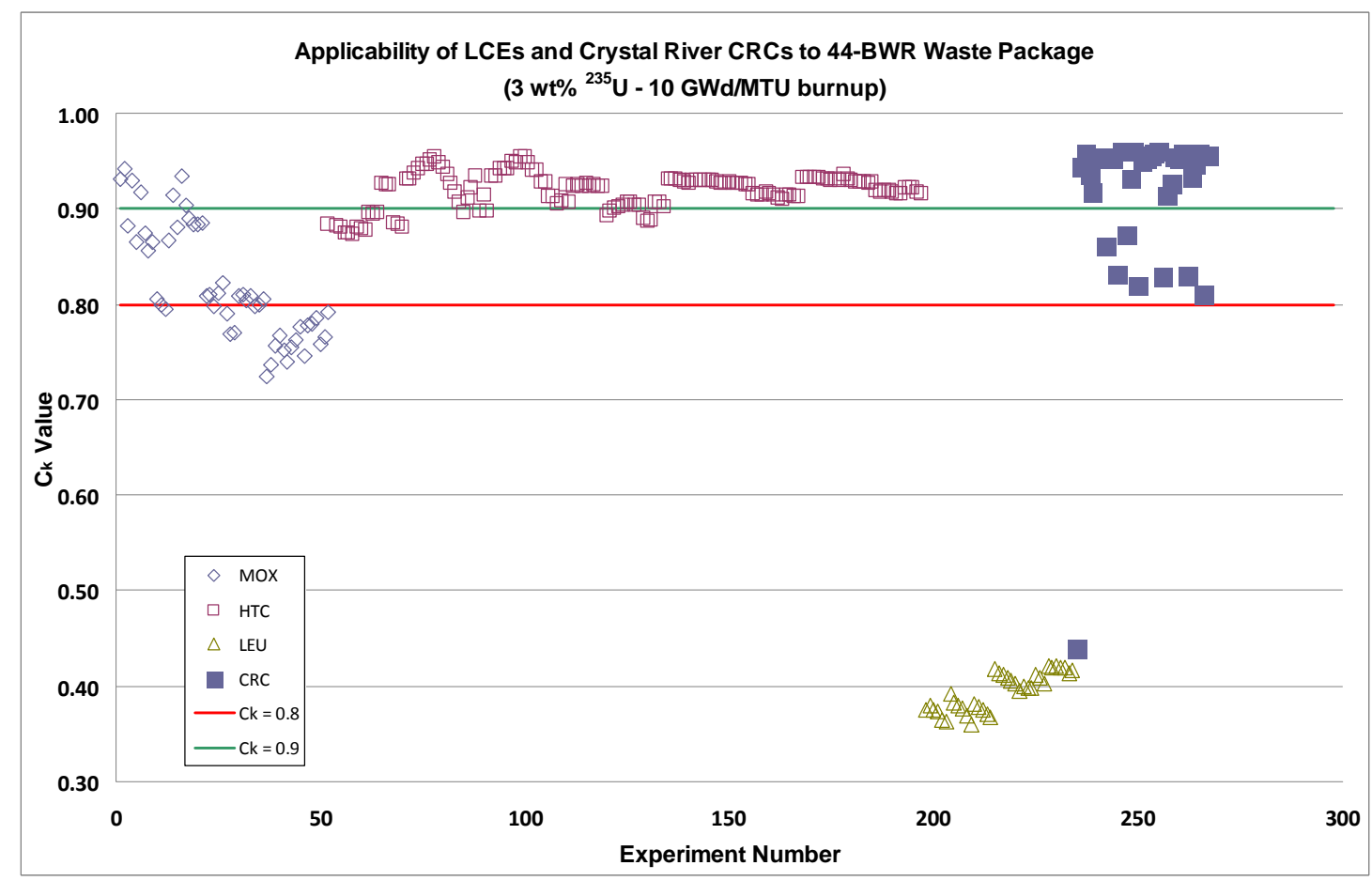

Fig. 11. $c_{k}$ as a function of experiment number: 44-BWR waste package, CSNF of $3 \mathrm{wt} \%{ }^{235} \mathrm{U}$ initial enrichment, and 10-GWd/MTU burnup.

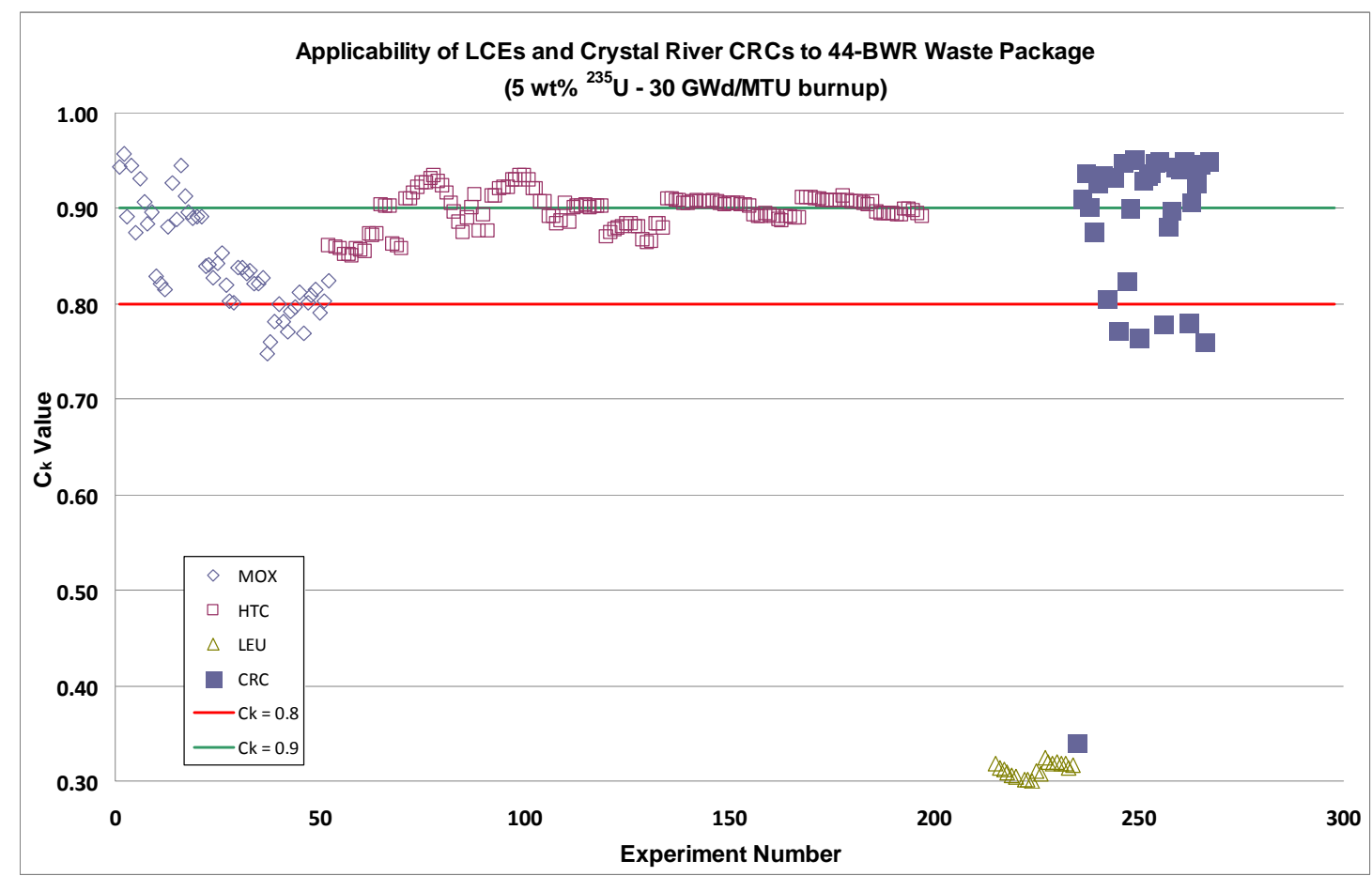

Fig. 12. $c_{k}$ as a function of experiment number: 44-BWR waste package, CSNF of $5 \mathrm{wt} \%{ }^{235} \mathrm{U}$ initial enrichment, and 30-GWd/MTU burnup. 


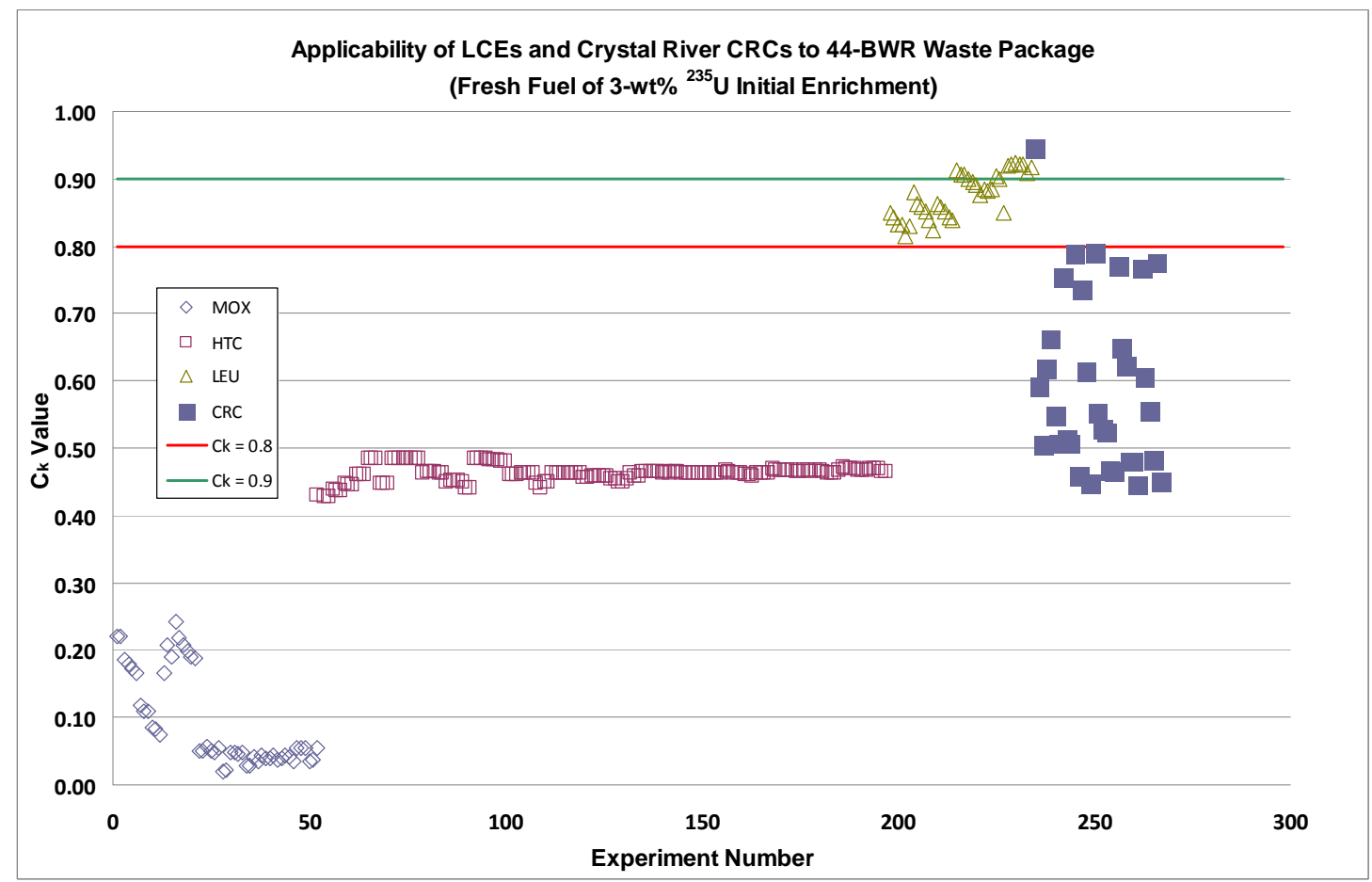

Fig. 13. $c_{k}$ as a function of experiment number: 44-BWR waste package, fresh fuel of $3 \mathrm{wt} \%{ }^{235} \mathrm{U}$ initial enrichment. 


\subsection{DETERMINATION OF BIAS AND BIAS UNCERTAINTY}

This section describes the methods used to determine a lower bound tolerance limit for the applications evaluated in this calculation report and the calculation result analyses.

\subsubsection{Methods}

Bias and bias uncertainty over the area of applicability of critical experiments are determined using the guidance in ANSI/ANS-8.1-1998 and ANSI/ANS 8.17-2004. The accuracy of the computational method and cross-section data is established by evaluating critical experiments. Computational bias is the difference between calculated and experimental results. The uncertainty in bias is an allowance for uncertainties in the experiment conditions, the lack of accuracy and precision in the calculational method, and the extension of the area of applicability, if applicable. Generally, the bias and bias uncertainty are expected to be functions of various physical or neutronic parameters that can be determined using trending analyses. This technique can be applied to establish bias and bias uncertainty because $k_{\text {eff }}$ values usually exhibit an increasing or decreasing trend as a function of parameters such as lattice pitch, ${ }^{235} \mathrm{U}$ or other fissile concentration, hydrogen-to-uranium ratio, EALF, etc., that can be distinguished from random behavior. Statistical techniques exist for evaluating the bias and bias uncertainty and for establishing limits that can reliably be used to predict subcriticality, such as tolerance band, single-sided tolerance limit, and distribution-free tolerance limit (nonparametric) methods. ${ }^{1}$ These methods use bias and the bias uncertainty in combination with additional considerations (e.g., administrative margins, where applicable) to establish a critical limit (CL) (single value or a function, depending on the method applied) above which a desired fraction of the true population of $k_{\text {eff }}$ values calculated for critical systems is expected to lie, with a prescribed confidence and within the area of applicability. The parametric methods require that the $k_{\text {eff }}$ values for the applicable critical experiments form a normal distribution. When the $k_{\text {eff }}$ values for the critical experiments are not normally distributed about a mean value, a nonparametric statistical treatment (i.e., distribution-free methods) should be used.

Based on Section 5 of ANSI/ANS 8.17-2004, the CL is represented as ${ }^{1}$

$$
C L(x)=f(x)-\Delta k_{E R O A}-\Delta k_{I S O}-\Delta k_{m},
$$

where

$$
\begin{aligned}
& x \quad=\quad \text { a neutronic parameter used for trending; } \\
& f(x)=\quad \text { the lower bound tolerance limit function accounting for biases and uncertainties } \\
& \text { that cause the calculation results to deviate from the true value of } k_{\text {eff }} \text { for a critical } \\
& \text { experiment, as reflected over an appropriate set of critical experiments; } \\
& \Delta k_{E R O A}=\text { penalty for extending the range of applicability; } \\
& \Delta k_{\text {ISO }}=\text { penalty for isotopic composition bias and uncertainty; and } \\
& \Delta k_{m}=\text { an arbitrary margin ensuring subcriticality for preclosure and turning the CL } \\
& \text { function into an upper subcritical limit function (it is not applicable for use in } \\
& \text { postclosure analyses because there is no risk associated with a subcritical event). }
\end{aligned}
$$

This calculation report determines only the LBTL and the penalty for extending the range of applicability, if applicable, using the process described in Section 3.5.3.2 of Ref. 1 and illustrated in Figure 14. Note that the penalty for isotopic composition bias and uncertainty component of the CL, that is the $\Delta k_{I S O}$ term in the above equation, is not determined in this report (refer to Section 3.5.3.1 of Ref. 1 and Ref. 72 for the isotopic validation and the isotopic model, respectively). Linear regression, normal distribution tolerance limit (NDTL), and distribution-free tolerance limit (DFTL) methods are applied in this 
validation. For the linear regression models, statistical significance of trending is determined by the test of hypothesis that the slope differs from zero.

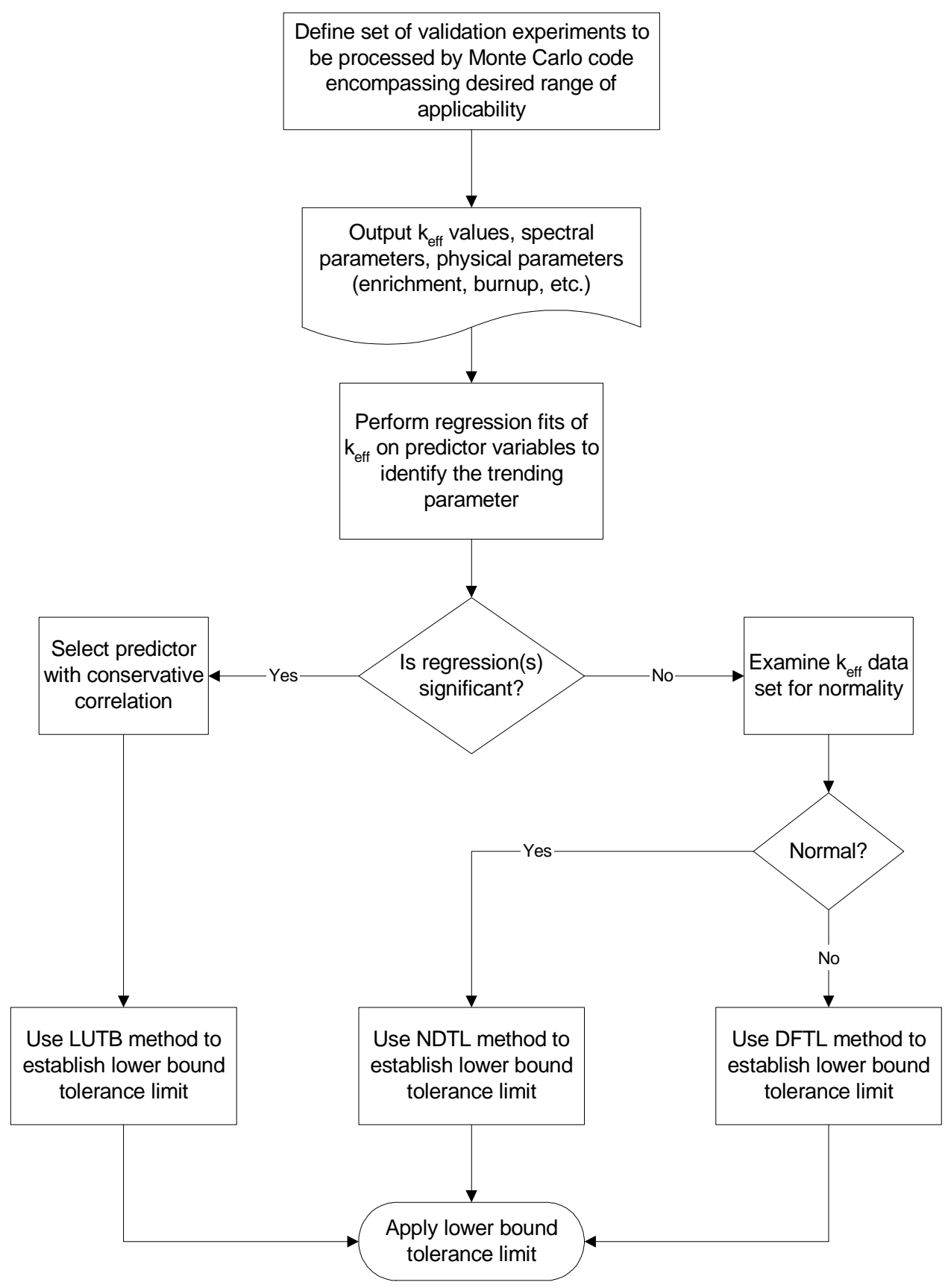

Note: $\mathrm{LUTB}=$ lower uniform tolerance band

NDTL $=$ normal distribution tolerance limit

DFTL $=$ distribution free tolerance limit

Fig. 14. Process for calculating lower bound tolerance limits. 


\subsubsection{Lower Uniform Tolerance Band Method}

The statistical methods referred to as upper subcritical limit (USL) Method 2 in References 18 (Appendix C), 19, and 20 were implemented in a spreadsheet application using only native Excel functions. The USL Method 2 uses a single-sided uniform-width closed-interval approach, also referred to as a lower uniform tolerance band (LUTB) approach. ${ }^{1,}{ }^{18}$ LUTB is the preferred method for estimating a conservative LBTL provided a significant trend is identified with a single predictor variable. ${ }^{1}$ The LBTL function is computed according to Eq. 1 (Ref. 18) and the equations for calculating the parameters in Eq. 1 are implemented in the spreadsheet application as described in Appendix E. The spreadsheet application also supports calculation of USLs based on extrapolation of similarity indices, such as $c_{k}$, to a value of 1.0, where the compared systems are considered to be identical for bias determination purposes. Regression fits, statistical significance of trending (refer to Eq. E-2, Appendix E), and the $\chi^{2}$ normality test (refer to Eq. E4, Appendix E) for the calculated $k_{\text {eff }}$ values for the evaluated critical experiment sets were obtained using Microsoft Excel.

$$
\operatorname{LBTL}(x)=1.0-\left(C_{\alpha / P} \cdot S_{P}\right)+\beta(x),
$$

where $x$ is a trending parameter, $S_{p}$ is the pooled variance of $k_{\text {eff }}$ values, and $\beta(x)=k_{\text {eff }}(x)-1$. The term $C_{\alpha / P} \cdot S_{P}$ provides a band for which there is a probability $P$ with a confidence $\alpha$ that an additional calculation of $k_{\text {eff }}$ for a critical system will lie within the band. For example, a 95/95 multiplier produces a LBTL for which there is a $95 \%$ confidence that 950 out of 1000 future calculations of critical systems will yield a value of $k_{\text {eff }}$ above the LBTL.

The following input parameters were used for the LUTB calculations described in Section 6.5.2:

$$
\begin{array}{ll}
P & =\text { proportion of population of critical experiments falling above lower tolerance level, } 0.95, \\
l-\gamma & =\text { confidence on fit, } 0.95, \text { and } \\
\alpha & =\text { confidence on proportion } P, 0.95 .
\end{array}
$$

\subsubsection{Distribution-Free Tolerance Limit Method}

The distribution-free tolerance limit method is typically used when trending is not appropriate and the $k_{\text {eff }}$ values for the critical experiments do not pass a test for normality. ${ }^{1}$ This method involves sorting all $k_{\text {eff }}$ values for the applicable critical experiments in ascending order and determining the degree of confidence for the fraction of the true population that lies above the smallest observed value. The percent confidence that a fraction of the population of $k_{\text {eff }}$ values calculated for critical systems is above the lowest observed value, $100 \alpha \%$, can be determined using the following equation (Ref. 75 ):

$$
\alpha=1-\sum_{j=0}^{m-1} \frac{n !}{j !(n-j) !}(1-p)^{j} p^{(n-j)}
$$

where

$\mathrm{n}=$ sample size,

$\mathrm{m}=$ rank order of the smallest $k_{\text {eff }}$ value, and

$\mathrm{p}=$ the desired population fraction above the smallest $k_{\text {eff }}$ value (normally 0.95 ). 
The single-valued $L B T L$ function for nonparametric data analysis is determined as follows:

$$
L B T L=\text { smallest } k_{\text {eff }} \text { value }- \text { uncertainty for smallest } k_{\text {eff }} \text { value }- \text { nonparametric margin. }
$$

Note that the confidence value determined by Eq. 2 increases with increasing sample size and the nonparametric margin is used to account for small sample size in Eq. 3 (e.g., the recommended margins are $0.0,0.01$, and 0.02 when confidence values are greater than $90 \%$, from $80 \%$ to $90 \%$, and from $70 \%$ to $80 \%$, respectively) (Ref. 75).

\subsubsection{Normal Distribution Tolerance Limit}

The normal distribution tolerance limit method is used for conditions in which the values of $k_{\text {eff }}$ for the critical experiments do not exhibit significant trends and form a normal distribution. A single-valued lower bound tolerance limit can be calculated as ${ }^{1}$

$$
L B T L=k_{\text {ave }}-k(\gamma, P, n) \times S_{P}
$$

where

$k_{\text {ave }} \quad=$ the average of the $k_{\text {eff }}$ values, unless $k_{\text {eff }}$ is greater than unity (1.0), in which instance the appropriate value for $k_{\text {ave }}$ should be 1.0 to disallow positive uncertainty,

$k(\gamma, P, n)=$ a multiplier (Ref. 76) in which $\gamma$ is the confidence level, $P$ is the proportion of the population covered, and $n$ is the sample size, and

$S_{P} \quad=$ the square root of the sum of the inherent variance of the critical experiment data set plus the average of the criticality code variances for the critical experiment data set.

\subsubsection{Analyses}

The following analyses use the process for calculating lower bound tolerance limits illustrated in Figure 14 and the methods described in Sections 6.5.1.1, 6.5.1.2, and 6.5.1.3. The analyses and LBTL calculations required the following prerequisites. An additional uncertainty of $2 \%$ (two standard deviations, 95\% level) in the $k_{\text {eff }}$ values for the CRCs was included in the statistical evaluation for LBTL. The justification for this uncertainty value is provided in Section 6.3.3. The MCNP $k_{\text {eff }}$ values for critical experiments with an experimental $k_{\text {eff }}$ value different from unity (mainly the MOX LCEs; see Appendix A, Tables A-1 through A-4) were normalized to unity, that is, divided by the experimental $k_{\text {eff }}$ value.

A first set of trending analyses focused on the LBTL determination using the LUTB method for the most reactive CSNF waste package configuration that contained burned fuel. This configuration is the designbasis 21-PWR waste package containing CSNF of $3.0 \mathrm{wt} \%{ }^{235} \mathrm{U}$ and $15-\mathrm{GWd} / \mathrm{MTU}$ burnup $\left(k_{e f f}=\right.$ $0.97166)$ (refer to Table 16 for $k_{\text {eff }}$ values for the evaluated configurations). The trends in $k_{\text {eff }}$ values for applicable critical experiments $\left(c_{k} \geq 0.8\right)$ were examined as functions of predictor variables $c_{k}, E A L F$, and burnup (where applicable), and the LBTL function was determined using Eq. 1. The results are summarized in Table 18. Figures 15 and 16 illustrate the LBTL trends as a function of burnup and EALF for cases 8 and 1 shown in Table 18, respectively. Note that the error bars in the graph reflect the $k_{\text {eff }}$ uncertainties considered in trending analyses. The results in Table 18 show that the trending using EALF parameter yields lower LBTL values as compared with the trending using integral index $c_{k}$. Case 3 in Table 18 shows the LBTL values using the critical experiments that are highly similar to the application systems $\left(c_{k} \geq 0.9\right)$ and $E A L F$ as the trending parameter. This selection mostly reduced the number of MOX LCEs and CRCs to be considered for bias determination. As seen in the table, the LBTL values based on highly similar critical experiments $\left(c_{k} \geq 0.9\right)$ are less conservative than those based on similar and marginally similar critical experiments $\left(c_{k} \geq 0.8\right)$. 
As expected, trending analyses using only applicable CRCs produce the most limiting LBTL due to the additional uncertainty of $1 \%$ (one standard deviation) used in LBTL determination, whereas the combined sets of HTC and MOX critical experiments produce the least limiting LBTL since very small uncertainties are associated with these LCE sets. Note that the waste package $k_{\text {eff }}$ has significant sensitivities to major actinides and the reactivity worth of minor actinides and fission product isotopes present in the application systems vary from approximately $5 \%$ to $8 \%$ (refer to the $k_{\text {eff }}$ results included in /DVD/apps/21 pwr/mcnp/rw and /DVD/apps/44bwr/mcnp/rw for fuel compositions containing only minor actinides and fission product isotopes). Therefore, the HTC LCEs and MOX LCEs should be included along with the CRCs in bias and bias uncertainty determination since significant correlation between the cross-section uncertainties in these LCEs and the application systems exists. The use of the applicable experiments $\left(c_{k} \geq 0.8\right)$ from the combined HTC LCEs, MOX LCEs, and CRCs and trending analysis using the $E A L F$ parameter are the most appropriate for LBTL determination.

Table 18. LBTL functions from trending with $E A L F, c_{k}$, and burnup using various sets of applicable critical experiments

\begin{tabular}{|c|c|c|c|c|c|c|}
\hline $\begin{array}{c}\text { Case } \\
\text { no. }\end{array}$ & $\begin{array}{l}\text { Excel } \\
\text { file }^{a}\end{array}$ & $\begin{array}{c}\text { Trend } \\
\text { parameter }\end{array}$ & $\begin{array}{l}\text { Parameter } \\
\text { value }\end{array}$ & $\begin{array}{l}\text { LBTL } \\
\text { value }\end{array}$ & LBTL function & Range of applicability \\
\hline \multicolumn{7}{|c|}{ MOX, HTC \& CRCs $-c_{k} \geq 0.8$} \\
\hline 1 & case1 & $E A L F^{b}$ & 0.3158 & 0.9800 & $0.9796+E A L F \cdot 1.1973 \mathrm{E}-03$ & $6.84 \mathrm{E}-02 \leq E A L F \leq 1.04 \mathrm{E}+00$ \\
\hline 2 & case 2 & $c_{k}$ & 1.0000 & 0.9878 & $\mathrm{~N} / \mathrm{A}^{c}$ & $\mathrm{~N} / \mathrm{A}$ \\
\hline \multicolumn{7}{|c|}{ MOX, HTC \& CRCs $-c_{k} \geq 0.9$} \\
\hline 3 & case3 & $E A L F$ & 0.3158 & 0.9835 & $0.9829+E A L F \cdot 1.7352 \mathrm{E}-03$ & $6.84 \mathrm{E}-02 \leq E A L F \leq 9.68 \mathrm{E}-01$ \\
\hline \multicolumn{7}{|c|}{$\mathrm{MOX} \& \mathrm{HTC}-c_{k} \geq 0.8$} \\
\hline 4 & case4 & $E A L F$ & 0.3158 & 0.9822 & $0.9838-E A L F \cdot 4.9777 \mathrm{E}-03$ & $6.84 \mathrm{E}-02 \leq E A L F \leq 8.89 \mathrm{E}-01$ \\
\hline 5 & case5 & $c_{k}$ & 1.0000 & 0.9928 & $\mathrm{~N} / \mathrm{A}$ & $\mathrm{N} / \mathrm{A}$ \\
\hline \multicolumn{7}{|c|}{ CRCs $-c_{k} \geq 0.8$} \\
\hline 6 & case6 & $E A L F$ & 0.3158 & 0.9639 & $0.9605+E A L F \cdot 1.0702 \mathrm{E}-02$ & $2.20 \mathrm{E}-01 \leq E A L F \leq 1.04 \mathrm{E}+00$ \\
\hline $7^{d}$ & case 7 & $c_{k}$ & 1.0000 & 0.9704 & $\mathrm{~N} / \mathrm{A}$ & $\mathrm{N} / \mathrm{A}$ \\
\hline 8 & case8 & $B U^{e}$ & 15.000 & 0.9639 & $0.9677-B U \cdot 2.551 \mathrm{E}-04$ & $9.99 \mathrm{E}-01 \leq B U \leq 3.30 \mathrm{E}+01$ \\
\hline \multicolumn{7}{|c|}{$\begin{array}{l}{ }^{a} \text { Excel application included in the DVD attachment, path: /DVD/cl/Table18. } \\
{ }^{b} E A L F \text { in } \mathrm{eV} \text {. }\end{array}$} \\
\hline
\end{tabular}

The analysis performed for the design-basis 21-PWR waste package containing CSNF of $3.0 \mathrm{wt} \%{ }^{235} \mathrm{U}$ and 15-GWd/MTU burnup determined (1) use of the applicable experiments $\left(c_{k} \geq 0.8\right)$ from the combined HTC LCEs, MOX LCEs, and CRCs and trending analysis using the EALF parameter are the most appropriate for LUTB determination, (2) the application system EALFs are within the area of applicability of the combined HTC LCEs, MOX LCEs, and CRCs, and (3) the regression analysis using the EALF parameter as the independent variable identifies a bias in $k_{\text {eff }}$ results that distinguishes from statistical fluctuations. Note that the LBTL for this application system has a weak variation with EALF over the area of applicability and the statistical significance of trending with $E A L F$ is further determined using the test statistic in Eq. E-2, Appendix E, and $\alpha=.05$ level of significance in the spreadsheet $/ \mathrm{DVD} / \mathrm{cl} /$ Table18/case1.xls. The result of the hypothesis testing is that the null hypothesis that $\beta_{1}=0$ cannot be rejected at $\alpha=.05$ level of significance and the $k_{e f f}$ values of the applicable HTC LCEs, MOX LCEs, and CRCs do not exhibit a significant trend with the parameter EALF. The statistical significance of trending for all application systems was tested in the spreadsheets included in $/ \mathrm{DVD} / \mathrm{cl} /$ tests and showed that regression using the parameter $E A L F$ is not statistically significant. Figure 17 illustrates the LBTL trend with EALF for the fresh fuel 21-PWR and 44-BWR waste packages. As 
required by the criticality model illustrated in Figure 14, the $k_{\text {eff }}$ values for applicable critical experiments will be further tested for normality.

The $\chi^{2}$ test for normality was performed for all evaluated application systems using the test statistic in Eq. E-3, Appendix E, in the spreadsheets included in /DVD/cl/tests and showed that the $k_{\text {eff }}$ values for the LEU LCEs (36 data points) that are applicable to the validation of criticality calculations for fresh fuel waste packages pass the normality test, whereas the $k_{\text {eff }}$ values for the combined MOX LCE, HTC LCE, and CRC sets ( $\sim$ between 218 and 238 data points, depending on the application), which are applicable to validation of criticality calculations for waste packages containing burned fuel, do not pass the normality test. For these sets, the distribution has a positive kurtosis, which indicates a relatively peaked distribution, and is negatively skewed, which indicates an asymmetric tail extending toward smaller $k_{\text {eff }}$ values.

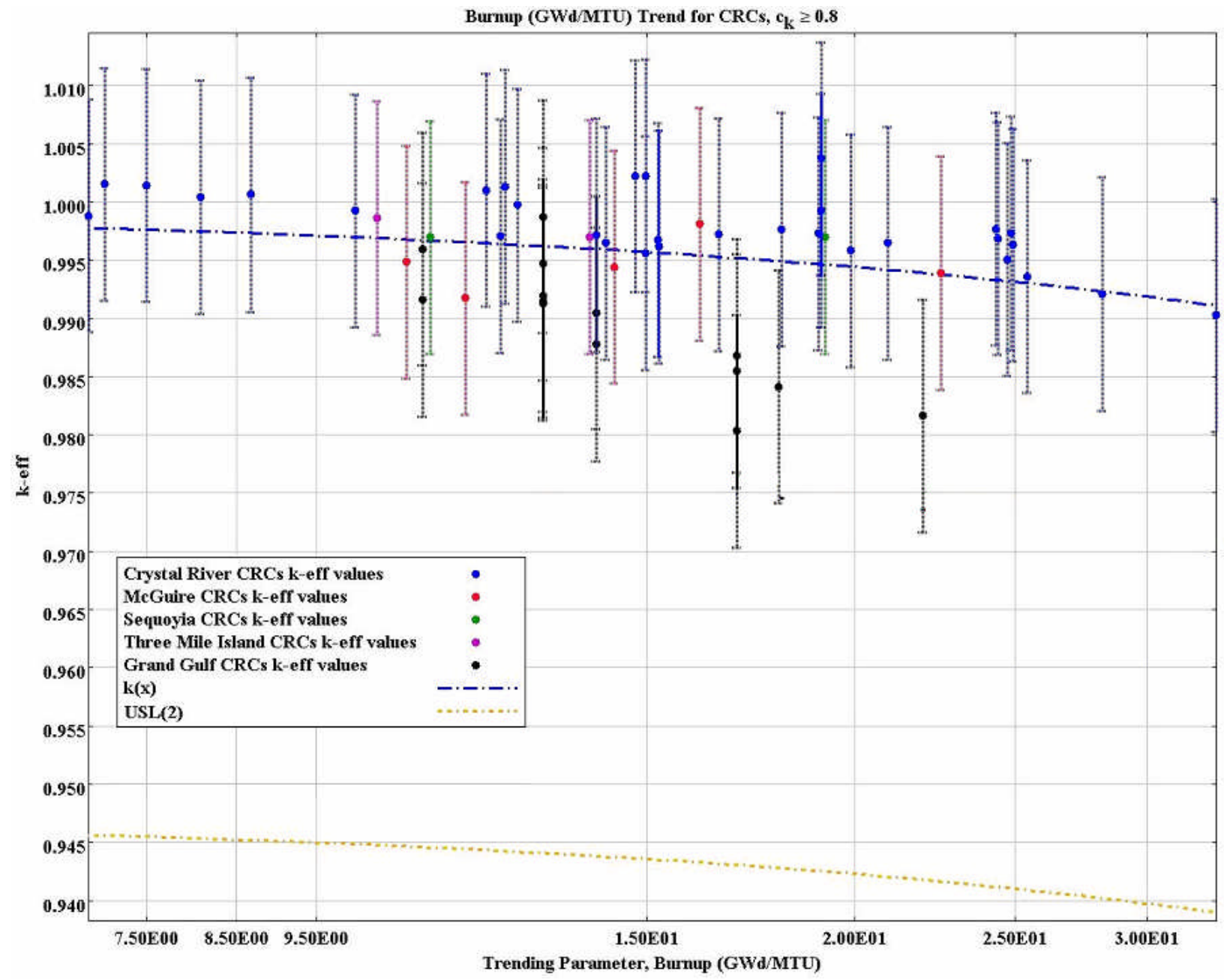

Note: The error bars on the $k_{\text {eff }}$ values show a single standard deviation of $1 \%$ assigned to the CRC state-points.

Fig. 15. Burnup trend for CRC state-points. 
EALF Trend for HTC\&MOX\&CRCs, ck $\geq 0.8$

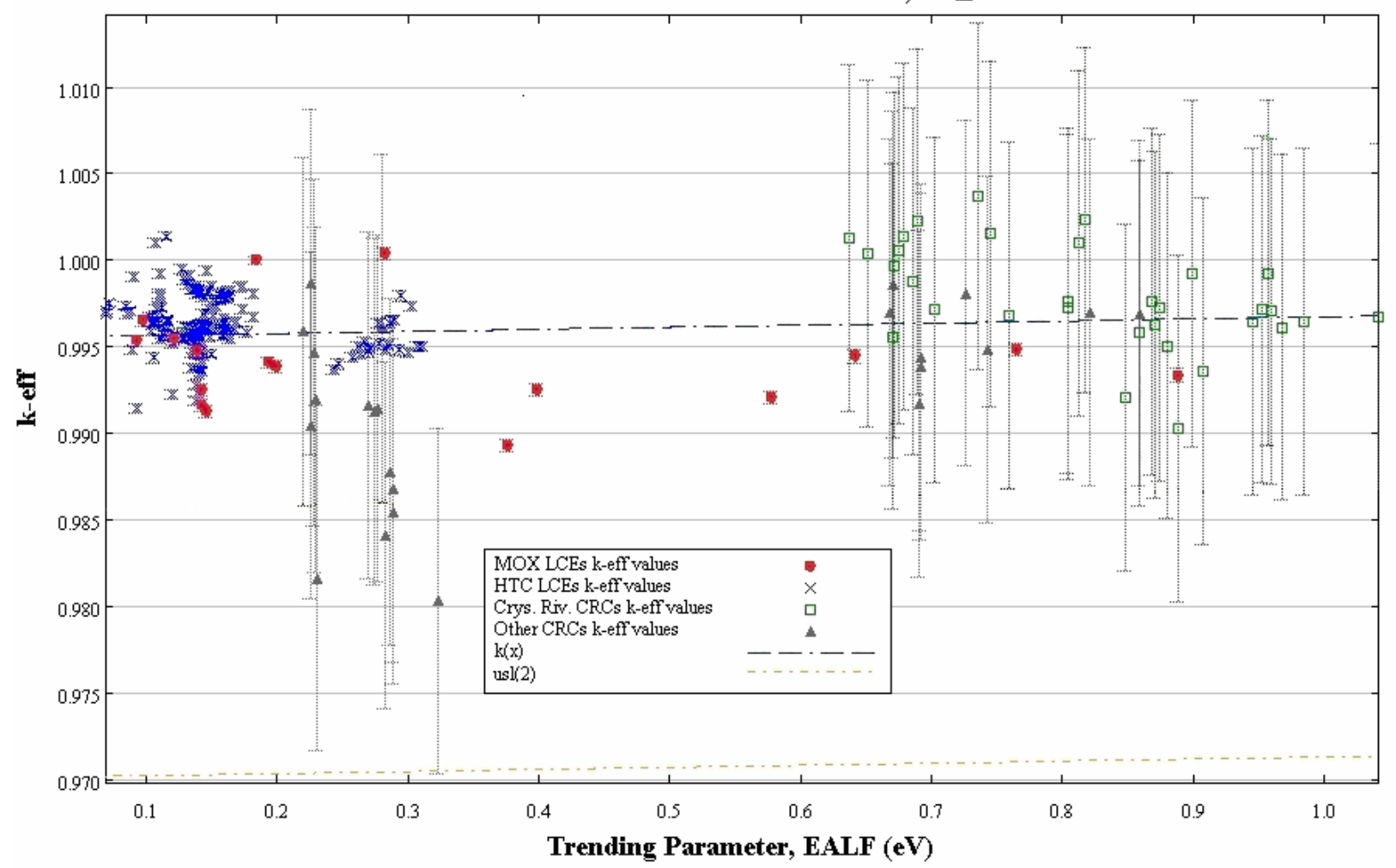

Note: The error bars on the $k_{\text {eff }}$ values for the CRC cases show a single standard deviation of $1 \%$ assigned to the CRC state-points.

Fig. 16. EALF trend for HTC LCEs, MOX LCEs, and CRCs. 


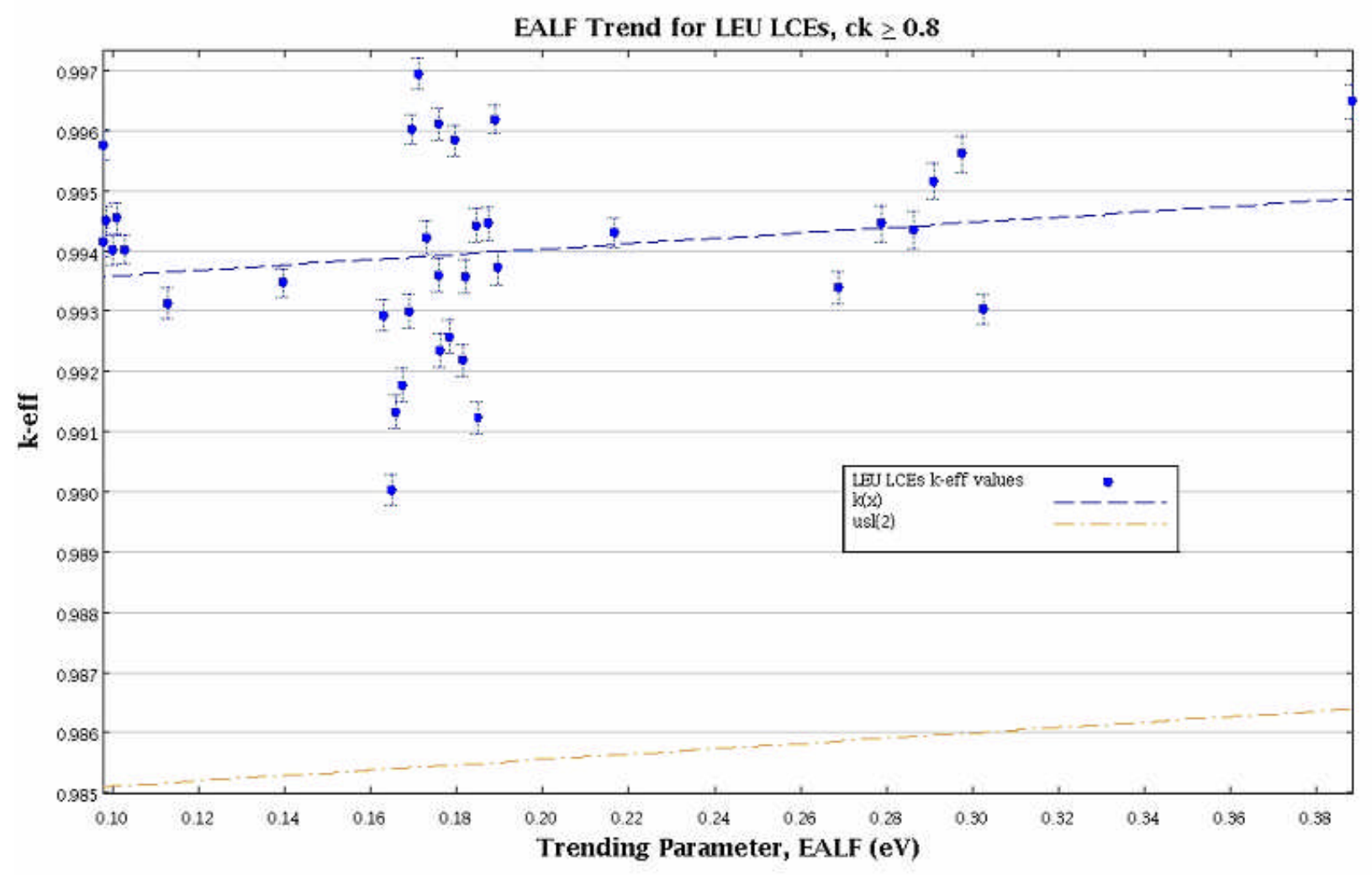

Fig. 17. EALF trend for the LEU LCEs applicable to the validation of criticality calculations for fresh fuel waste packages.

The $k_{\text {eff }}$ values of the HTC, MOX, and CRC experiments $\left(c_{k} \geq 0.8\right)$ that are applicable to validation of criticality calculations for waste packages containing burned fuel were further analyzed using the DFTL method since this combined set does not pass a normality test. Table 19 summarizes the results of the DFTL method based on Eqs. 2 and 3 (see Section 6.5.1.2), which are available in /DVD/cl/NDTL\&DFTL.xls, worksheet DFTL-ptt15. The table shows the 1st- through the 7th-order statistics of the $k_{\text {eff }}$ values for 218 applicable critical experiments (145 HTC LCEs, 56 CRCs, and 17 MOX LCEs), the percentage confidence that the $k_{\text {eff }}$ population lies above each order statistic, $100 \alpha \%$, and the LBTL obtained by subtracting analysis and MCNP calculation statistical uncertainties from the $k_{\text {eff }}$ value. Note that these order statistics consist of $k_{\text {eff }}$ values for Grand Gulf state-points. In the calculations, the desired percentage of the $k_{\text {eff }}$ values from applicable critical experiments above the LBTL is $95 \%$ (Ref. 75). Based on the nonparametric analysis, the percentage confidence values that $95 \%$ of the $k_{\text {eff }}$ population lies above $0.9703,0.9716,0.9741,0.9755,0.9768,0.9778$, and 0.9803 are $100 \%, 99.98 \%$, $99.89 \%, 99.55 \%, 98.57 \%, 96.36 \%$, and $92.25 \%$, respectively. The 0.9778 value is used in this validation as a slightly conservative limit to ensure that $95 \%$ of the future calculations of CSNF waste packages containing burned fuel will yield a value above this limit at the $95 \%$ confidence level. The results of the nonparametric analysis apply to all application systems containing burned fuel since the first seven-order statistics for those systems consist of the $k_{\text {eff }}$ values for Grand Gulf state-points provided in Table 19, second column. 
Table 19. LBTL from the nonparametric method

\begin{tabular}{|c|c|c|c|c|c|c|}
\hline Rank & $\boldsymbol{k}_{\text {eff }}$ & $100 \alpha \%$ & $\boldsymbol{\sigma}_{\mathbf{a}}$ & $\boldsymbol{\sigma}_{\mathbf{s}}$ & $\boldsymbol{\sigma}^{\boldsymbol{a}}$ & LBTL \\
\hline 1 & 0.9803 & 100.00 & 0.01 & 0.0001 & 0.0100 & 0.9703 \\
\hline 2 & 0.9816 & 99.98 & 0.01 & 0.0001 & 0.0100 & 0.9716 \\
\hline 3 & 0.9841 & 99.89 & 0.01 & 0.0001 & 0.0100 & 0.9741 \\
\hline 4 & 0.9855 & 99.55 & 0.01 & 0.0001 & 0.0100 & 0.9755 \\
\hline 5 & 0.9868 & 98.57 & 0.01 & 0.0001 & 0.0100 & 0.9768 \\
\hline 6 & 0.9878 & 96.36 & 0.01 & 0.0001 & 0.0100 & 0.9778 \\
\hline 7 & 0.9903 & 92.25 & 0.01 & 0.0001 & 0.0100 & 0.9803 \\
\hline
\end{tabular}

${ }^{a} \sigma=\sqrt{\sigma_{a}^{2}+\sigma_{s}^{2}}$, where $\sigma_{\mathrm{a}}$ and $\sigma_{\mathrm{s}}$ are analysis and MCNP statistical calculation uncertainties, respectively.

The $k_{\text {eff }}$ values of the 36 LEU LCEs $\left(c_{k} \geq 0.8\right.$ ) (see Table 17) applicable to the validation of criticality calculations for fresh fuel waste packages were further analyzed using the normal distribution tolerance limit method (Eq. 4) since this set of critical experiments passes a normality test. The LBTL is determined in the spreadsheet available in /DVD/cl/NDTL\&DFTL.xls, worksheet NDTL, and is applicable to all evaluated fresh fuel application systems. The applicable value for the multiplier $k(\gamma, P, n)$ in Eq. 4 is 2.166 for 36 data points, $95 \%$ confidence level, and a fraction of the $k_{\text {eff }}$ population of $95 \%$ (Ref. 76). The LBTL for fresh fuel waste package applications is 0.9905 . 



\section{CONCLUSIONS}

The calculations and analyses documented in this report apply the criticality analysis methodology approach documented in Section 3.5 of the Disposal Criticality Methodology Topical Report ${ }^{1}$ (refer to Sections 6.4 and 6.5 for the criticality model overview and the process for calculating lower bound tolerance limits, respectively) for validating the computational method used to perform postclosure criticality calculations, which is MCNP Version5/Revision 1.40 and nuclear data based primarily on the ENDF/B-VI library. The application systems for this validation consist of waste packages containing TAD canisters loaded with CSNF of varying assembly types, initial enrichments, and burnups that are expected from the waste stream and of varying degree of internal component degradation that may occur over the 10,000-year regulatory time period. The critical experiments considered for use in the validation process were selected based on physical characteristic similarities between the application systems and the critical experiments and include the following: proprietary HTC MOX LCEs, public MOX and LEU LCEs, and CRCs. Subsequently, S/U analyses were performed for these experiments, and neutronic similarity based on the integral index $c_{k}$ value and published guidance was used to identify and select the critical experiments that are most applicable for this validation. Critical experiments having $c_{k}>0.8$ (approximately 200 critical experiments for the CSNF waste packages containing irradiated fuel, depending on the actual configuration, and 36 critical experiments for the CSNF waste packages containing fresh fuel) were retained and used for determining the LBTL. The single-valued LBTL functions and the corresponding range of applicability for the evaluated applications are presented in Table 20 .

Table 20. LBTL and corresponding range of applicability

\begin{tabular}{|l|c|c|c|}
\hline \multicolumn{1}{|c|}{ Application systems } & LBTL & Method $^{a}$ & ${\text { Range of applicability; } \boldsymbol{E A L F} \text { in } \mathbf{~ V}^{b}}^{\boldsymbol{b}}$ \\
\hline $\begin{array}{l}\text { 21-PWR waste packages } \\
\text { containing fresh fuel }\end{array}$ & 0.9905 & NDTL & $0.0977 \leq E A L F \leq 0.3882$ \\
\hline $\begin{array}{l}\text { 21-PWR waste packages } \\
\text { containing burned fuel }\end{array}$ & 0.9778 & DFTL & $0.0684 \leq E A L F \leq 1.0410$ \\
\hline $\begin{array}{l}\text { 44-BWR waste packages } \\
\text { containing fresh fuel }\end{array}$ & 0.9905 & NDTL & $0.0977 \leq E A L F \leq 0.3882$ \\
\hline $\begin{array}{l}\text { 44-PWR waste packages } \\
\text { containing burned fuel }\end{array}$ & 0.9778 & DFTL & $0.0421 \leq E A L F \leq 0.9679$ \\
\hline
\end{tabular}

${ }^{a}$ Fraction of the $k_{\text {eff }}$ population above the LBTL value is $95 \%$; the confidence on population is $95 \%$.

${ }^{b}$ This column shows the $E A L F$ range for the critical experiments used to determine the single-valued LBTL function. 



\section{REFERENCES}

1. Disposal Criticality Analysis Methodology Topical Report. YMP/TR-004Q, Rev. 02. Las Vegas, Nevada: Yucca Mountain Site Characterization Project, 2003.

2. 10 CFR 63. 2005. Energy: Disposal of High-Level Radioactive Wastes in a Geologic Repository at Yucca Mountain, Nevada.

3. X-5 Monte Carlo Team, MCNP-A General Monte Carlo N-Particle Transport Code, Version 5Volume I: Overview and Theory, LA-UR-03-1987 (April 24, 2003, Revised Oct. 3, 2005).

Available from Radiation Safety Information Computational Center at Oak Ridge National Laboratory as CCC-730.

4. ANSI/ANS-8.1-1998. Nuclear Criticality Safety in Operations with Fissionable Material Outside Reactors. La Grange Park, Illinois: American Nuclear Society.

5. ANSI/ANS-8.17-2004. Criticality Safety Criteria for the Handling, Storage, and Transportation of LWR Fuel Outside Reactors. La Grange Park, Illinois: American Nuclear Society.

6. Test Plan for: Range of Applicability and Bias Determination for Postclosure Criticality, TWPOCRWM-LL-ORNL-01 Rev 00.

7. Calculation Packages, ORNL-OCRW-19.1, Revision 01, CN 00.

8. Scientific Investigations, ORNL-OCRW-21.0.

9. Control of the Electronic Management of Data, ORNL-OCRW-23.0, Revision 01, CN 01.

10. Software Control, ORNL-OCRW-19.0, Revision 04, CN 00.

11. MCNP-YMP Software Verification Report for OSF1_V5, ORNL OCRW-SQA-013, Rev. 0, July 17, 2007.

12. MCNP-YMP Software Verification Report for Linux_2, ORNL OCRW-SQA-015, Rev. 0, July 19, 2007.

13. SCALE: A Modular Code System for Performing Standardized Computer Analyses for Licensing Evaluations, ORNL/TM-2005/39, Version 5.1, Vols. I-III, November 2006. Available from Radiation Safety Information Computational Center at Oak Ridge National Laboratory as CCC-732.

14. S. Goluoglu, N. F. Landers, L. M. Petrie, and D. F. Hollenbach, "CSAS: Control Module for Enhanced Criticality Safety Analysis Sequences," Vol. II, Book 1, Sect. C4 in SCALE: A Modular Code System for Performing Standardized Computer Analyses for Licensing Evaluations, ORNL/TM-2005/39, Version 5.1, Vols. I-III, November 2006. Available from Radiation Safety Information Computational Center at Oak Ridge National Laboratory as CCC-732. 
15. B. T. Rearden, "TSUNAMI-3D: Control Module for Three-Dimensional Cross-Section Sensitivity and Uncertainty Analysis for Criticality," Vol. I, Book 2, Sect. C9 in SCALE: A Modular Code System for Performing Standardized Computer Analyses for Licensing Evaluations, ORNL/TM-2005/39, Version 5.1, Vols. I-III, November 2006. Available from Radiation Safety Information Computational Center at Oak Ridge National Laboratory as CCC-732.

16. B. T. Rearden, "Sensitivity Utility Modules," Vol. III, Book 3, Sect. M18 in SCALE: A Modular Code System for Performing Standardized Computer Analyses for Licensing Evaluations, ORNL/TM-2005/39, Version 5.1, Vols. I-III, November 2006. Available from Radiation Safety Information Computational Center at Oak Ridge National Laboratory as CCC-732.

17. SCALE-YMP Software Verification Report for OSF1_V5, ORNL OCRW-SQA-010, Rev. 1, July 13, 2007.

18. J. J. Lichtenwalter, S. M. Bowman, M. D. DeHart, and C. M. Hopper, Criticality Benchmark Guide for Light-Water-Reactor Fuel in Transportation and Storage Packages, NUREG/CR-6361 (ORNL/TM-13211), U.S. Nuclear Regulatory Commission, Oak Ridge National Laboratory, March 1997.

19. D. C. Bowden and F. A. Graybill, "Confidence Bands of Uniform and Proportional Width for Linear Models,” Am. Stat. Assoc. J., 61, 182 (March 1966).

20. N. L. Johnson, Ed., “Query,” Technometrics 10, 207-209 (February 1968).

21. Quality Assurance Requirements and Description. DOE/RW-0333P, Rev. 19. U.S. Department of Energy, Office of Civilian Radioactive Waste Management, Washington, D.C., 2007.

22. G. Audi and A.H. Wapstra. Atomic Mass Adjustment, Mass List for Analysis. Brookhaven National Laboratory, National Nuclear Data Center, Upton, New York, 1995.

23. J. R. Parrington, H. D. Knox, S. L. Breneman, E. M. Baum, and F. Feiner. Nuclides and Isotopes, Chart of the Nuclides. 15th Edition. San Jose, California: General Electric Company and KAPL, Inc, 1996.

24. Total System Performance Assessment Data Input Package for Requirements Analysis for TAD Canister and Related Waste Package Overpack Physical Attributes Basis for Performance Assessment. TDR-TDIP-ES-000006 REV 00. Las Vegas, Nevada: Sandia National Laboratories, 2007.

25. Final Safety Analysis Report for the Holtec International Storage and Transfer Operation Reinforced Module Cask System (Hi-Storm 100 Cask System). Holtec Report HI-2002444. Two volumes. NRC Docket No. 72-1014. Marlton, New Jersey: Holtec International, 2002.

26. Evaluation of Neutron Absorber Materials Used for Criticality Control in Waste Packages. CAL-DS0-NU-000007 REV 00A. Las Vegas, Nevada: Bechtel SAIC Company, 2006.

27. Summary Report of Commercial Reactor Criticality Data for Crystal River Unit 3. TDR-UDCNU-000001 REV 02. Las Vegas, Nevada: Bechtel SAIC Company, 2001. 
28. N. H. Larsen, G. R. Parkos, and O. Raza. Core Design and Operating Data for Cycles 1 and 2 of Quad Cities 1. EPRI NP-240. Palo Alto, California: Electric Power Research Institute, 1976.

29. Summary Report of Commercial Reactor Criticality Data for Grand Gulf Unit 1. TDR-UDC-NU000002 REV 00. Las Vegas, Nevada: Bechtel SAIC Company, 2001.

30. Dimension and Material Specification Selection for Use in Criticality Analyses. CAL-DSU-NU000017 REV 0A. Las Vegas, Nevada: Bechtel SAIC Company, 2006.

31. Geochemistry of Repository Block. DTN: GS000308313211.001. Submittal date: 03/27/2000.

32. Matrix Hydrologic Properties Data. DTN: MO0109HYMXPROP.001. Submittal date: 09/17/2001.

33. Physical and Chemical Characteristics of Alloy 22. DTN: MO0003RIB00071.000. Submittal date: 03/13/2000.

34. 2001 ASME Boiler and Pressure Vessel Code (includes 2002 addenda). New York, New York: American Society of Mechanical Engineers, 2001.

35. ASTM G 1-90 (Reapproved 1999). Standard Practice for Preparing, Cleaning, and Evaluating Corrosion Test Specimens. West Conshohocken, Pennsylvania: American Society for Testing and Materials, 1999.

36. ASTM B 811-97. Standard Specification for Wrought Zirconium Alloy Seamless Tubes for Nuclear Reactor Fuel Cladding. West Conshohocken, Pennsylvania: American Society for Testing and Materials, 2000.

37. ASM International. Properties and Selection: Nonferrous Alloys and Special-Purpose Materials. Volume 2 of ASM Handbook. Formerly Tenth Edition, Metals Handbook. 5th Printing 1998. Materials Park, Ohio: ASM International, 1990.

38. ASM International, "Zircaloy-2, Nuclear Reactor Alloy, Filing Code: Zr-3 Zirconium Alloy." Alloy Digest, (July), Materials Park, Ohio: ASM International, 1967.

39. ASTM A 887-89 (Reapproved 2004). Standard Specification for Borated Stainless Steel Plate, Sheet, and Strip for Nuclear Application. West Conshohocken, Pennsylvania: American Society for Testing and Materials, 2004.

40. Isotopic Generation and Confirmation of the PWR Application Model. CAL-DSU-NU-000004 REV 00A. Las Vegas, Nevada: Bechtel SAIC Company, 2003.

41. H. L. Massie. Isotopic Generation and Confirmation of the BWR Application Model. 32-503584702. Las Vegas, Nevada: Areva, 2004.

42. PWR Axial Burnup Profile Analysis. CAL-DSU-NU-000012 REV 00A. Las Vegas, Nevada: Bechtel SAIC Company, 2003.

43. 21-PWR Waste Package with Absorber Plates Loading Curve Evaluation. CAL-DSU-NU-000006 REV 00C. Las Vegas, Nevada: Bechtel SAIC Company, 2004. 
44. 44-BWR Waste Package Loading Curve Evaluation. CAL-DSU-NU-000008 REV 00A. Las Vegas, Nevada: Bechtel SAIC Company, 2004.

45. International Handbook of Evaluated Criticality Safety Benchmark Experiments, NEA/NSC/DOC(95)03, NEA Nuclear Science Committee, September 2006.

46. Programme HTC Phase 1-4 Critical Experiment Reports. DTN: MO0709HTCCER14.000. Submittal date: 09/11/2007.

47. F. Fernex, "Programme HTC - Phase 1 : réseaux de crayons dans l'eau pure (Water-moderated and reflected simple arrays) Réévaluation des expériences," Note DSU/SEC/T/2005-33/D.R., IRSN, June 2006.

48. F. Fernex, "Programme HTC - Phase 2 : réseaux simples en eau empoisonnée (bore et gadolinium) (Reflected simple arrays moderated by poisoned water with gadolinium or boron) Réévaluation des expériences,” Note DSU/SEC/T/2005-38/D.R., IRSN, June 2006.

49. F. Fernex, "Programme HTC - Phase 3 : configurations "stockage en piscine" (Pool storage) Réévaluation des expériences,” Note DSU/SEC/T/2005-37/D.R., IRSN, June 2006.

50. F. Fernex, "Programme HTC - Phase 4 : Configurations "châteaux de transport"(Shipping cask) Réévaluation des expériences," Note DSU/SEC/T/2005-36/D.R., IRSN, June 2006.

51. Data Qualification Report: Qualification of the Haut Taux de Combustion Laboratory Critical Experiment Data for Use on the Yucca Mountain Project. TDR-EBS-NU-000006 REV 00. Las Vegas, Nevada: Sandia National Laboratories, 2007.

52. CRC Reactivity Calculations for Crystal River Unit 3. B00000000-01717-0210-00002 REV 00. Las Vegas, Nevada: CRWMS M\&O, 1998.

53. CRC Reactivity Calculations for Crystal River Unit 3. (DI\#: B00000000-01717-0210-00002 REV 00, CRWMS M\&O) Attachments I through IV - 3 Data Cartridges. Batch Number: MOY-980615-05.

54. CRC Reactivity Calculations for McGuire Unit 1. B00000000-01717-0210-00004 REV 00. Las Vegas, Nevada: CRWMS M\&O, 1998.

55. CRC Reactivity Calculations for McGuire Unit 1 (DI\#: B00000000-01717-0210-00004 REV 00) Attachments II through V - 1 Data Cartridge. Batch Number: MOY-980428-16.

56. CRC Reactivity Calculations for Sequoyah Unit 2, B00000000-01717-0210-00006 REV 00, Las Vegas, Nevada: CRWMS M\&O, 1998.

57. Sequoyah Unit 2 CRC Reactivity Calculations. (DI\#: B00000000-01717-0210-00006, CRWMS M\&O) - Attachments II through VI - 1 Data Cartridge. Batch Number: MOY-980428-18.

58. CRC Reactivity Calculations for Three Mile Island Unit 1. B00000000-01717-0210-00008 REV 00. Las Vegas, Nevada: CRWMS M\&O, 1998. 
59. CRC Reactivity Calculations for Three Mile Island Unit 1 (DI\#: B00000000-01717-0210-00008 REV 00)-Attachments I through IV - 1 Data Cartridge. Batch Number: MOY-980604-07.

60. J. W. Harwell, Commercial Reactor Reactivity Analysis for Grand Gulf, Unit 1, 32-5029393-00. Lynchburg, Virginia: Framatome ANP (2003).

61. Criticality Model. CAL-DS0-NU-000003 REV 00A. Las Vegas, Nevada: Bechtel SAIC Company, 2004.

62. Criticality Input to Canister Based System Performance Specification for Disposal. TDR-DS0-NU000002 REV 01. Las Vegas, Nevada: Sandia National Laboratories, 2007.

63. B. L. Broadhead, B. T. Rearden, C. M. Hopper, J. J. Wagschal, and C. V. Parks, "Sensitivityand Uncertainty-Based Criticality Safety Validation Techniques," Nuc. Sci. Eng. 146, 340-366 (2004).

64. B. T. Rearden, "Criticality Code Validation Exercises with TSUNAMI," Proceedings to the 8th International Conference on Nuclear Criticality Safety, St. Petersburg, Russia, May 28-June 1, 2007.

65. N. H. Williams. "Contract No. DE-AC28-01RW12101 - Licensing Position-009, Waste Stream Parameters." Letter from N. H. Williams (BSC) to J. D. Ziegler (DOE/ORD), November 13, 2003, 1105039412, with enclosure.

66. Waste Packages and Source Terms for the Commercial 1999 Design Basis Waste Stream. CALMGR-MD-000001 REV 00. Las Vegas, Nevada: CRWMS M\&O, 2000.

67. J. C. Wagner and C.V. Parks, Recommendations on the Credit for Cooling Time in PWR Burnup Credit Analyses, NUREG/CR-6781 (ORNL/TM-2001/272), U.S. Nuclear Regulatory Commission, Oak Ridge National Laboratory, 2003.

68. C. V. Parks, J. C. Wagner, D. E. Mueller, and I. C. Gauld, "Full Burnup Credit in Transport and Storage Casks - Benefits and Implementation," Radwaste Solutions 14(2), 32-41 (March/April 2007).

69. J. J. Sapyta, C. W. Mays, and J. W. Pegram, Jr., "Use of Reactor-Follow Data to Determine Biases and Uncertainties for PWR Spent Nuclear Fuel," Trans. Am. Nucl. Soc. 83, 137 (2000).

70. W. J. Anderson, P. M. O'Leary, and J. M. Scaglione, "Selection of Reactor Criticals as Benchmarks for Spent Nuclear Fuels," Trans. Am. Nucl. Soc. 83, 140 (2000).

71. J. M. Scaglione, D. P. Henderson, J. R. Worsham, and W. J. Anderson, "Applicability of CRC Benchmark Experiments for Burnup Credit Validation," Trans. Am. Nucl. Soc. 83, 138 (2000).

72. Isotopic Model for the Commercial SNF Burnup Credit. CAL-DSU-NU-000007 REV 00B. Las Vegas, Nevada: Bechtel SAIC Company, 2004.

73. G. Radulescu, D. E. Mueller, and J. C. Wagner, Sensitivity and Uncertainty Analysis of Commercial Reactor Criticals for Burnup Credit, NUREG/CR-6951 (ORNL/TM-2006/87), U.S. Nuclear Regulatory Commission, Oak Ridge National Laboratory, 2007. 
74. G. Radulescu, D. E. Mueller, and J. C. Wagner, "Evaluation of Applicability of CRC Models for Burnup Credit Validation," to be presented at the 2007 ANS/ENS International Meeting and Technology Expo, Washington, D.C., November 11-15, 2007.

75. NUREG/CR-6698, Guide for Validation of Nuclear Criticality Safety Calculational Methodology, U.S. Nuclear Regulatory Commission, Washington D.C., February 2006.

76. M. G. Natrella Experimental Statistics. National Bureau of Standards Handbook 91. U.S. Department of Commerce, National Bureau of Standards, Washington, D.C., 1963. 
APPENDIX A: Results of Criticality Calculations 

In this appendix, the results of criticality calculations for the selected HTC, MOX, and LEU LCEs and CRCs (refer to Section 6.3 for the section on critical experiments) are tabulated in Tables A-1 through A-4. All the results were obtained from jobs executed on the Dec Alpha workstations, unless otherwise noted.

Table A-1. Criticality calculation results for HTC LCEs

\begin{tabular}{|c|c|c|c|c|c|c|c|}
\hline \multicolumn{8}{|c|}{$\begin{array}{c}\text { HTC } \\
\text { (Experimental } k_{\text {eff }}=\mathbf{1 . 0 0 0 0} \text { for all) }\end{array}$} \\
\hline \multicolumn{4}{|c|}{$\mathrm{MCNP}^{a}$} & \multicolumn{4}{|c|}{ SCALE $^{b}$} \\
\hline $\begin{array}{l}\text { Output } \\
\text { filename }\end{array}$ & $\boldsymbol{k}_{\text {eff }}$ & $\sigma$ & $\begin{array}{c}E A L F \\
(\mathrm{eV})\end{array}$ & Filename $^{c}$ & $\boldsymbol{k}_{\text {eff }}$ & $\sigma$ & $\begin{array}{c}E A L F \\
(\mathrm{eV})\end{array}$ \\
\hline ohtc1c01 & 0.99752 & 0.00020 & $7.15 \mathrm{E}-02$ & htc1c1sen & 0.99889 & 0.00049 & $7.07 \mathrm{E}-02$ \\
\hline ohtc1c02 & 0.99711 & 0.00021 & $6.85 \mathrm{E}-02$ & htc1c2sen & 0.99616 & 0.00047 & $6.79 \mathrm{E}-02$ \\
\hline ohtc1c03 & 0.99693 & 0.00020 & $6.84 \mathrm{E}-02$ & htc1c3sen & 0.99740 & 0.00049 & $6.77 \mathrm{E}-02$ \\
\hline ohtc1c04 & 0.99705 & 0.00024 & $8.78 \mathrm{E}-02$ & htc1c4sen & 0.99718 & 0.00050 & $8.67 \mathrm{E}-02$ \\
\hline ohtc1c05 & 0.99690 & 0.00024 & $8.56 \mathrm{E}-02$ & htc1c5sen & 0.99717 & 0.00046 & $8.46 \mathrm{E}-02$ \\
\hline ohtc1c06 & 0.99737 & 0.00024 & $8.47 \mathrm{E}-02$ & htc1c6sen & 0.99737 & 0.00049 & $8.40 \mathrm{E}-02$ \\
\hline ohtc1c07 & 0.99647 & 0.00025 & $1.06 \mathrm{E}-01$ & htc1c7sen & 0.99675 & 0.00049 & $1.05 \mathrm{E}-01$ \\
\hline ohtc1c08 & 0.99642 & 0.00026 & $1.04 \mathrm{E}-01$ & htc1c8sen & 0.99599 & 0.00047 & $1.03 \mathrm{E}-01$ \\
\hline ohtc1c09 & 0.99676 & 0.00027 & $1.03 \mathrm{E}-01$ & htc1c9sen & 0.99608 & 0.00049 & $1.02 \mathrm{E}-01$ \\
\hline ohtc1c10 & 0.99609 & 0.00028 & $1.47 \mathrm{E}-01$ & htc1c10sen & 0.99498 & 0.00049 & $1.46 \mathrm{E}-01$ \\
\hline ohtc1c11 & 0.99542 & 0.00027 & $1.42 \mathrm{E}-01$ & htc1c11sen & 0.99313 & 0.00050 & $1.41 \mathrm{E}-01$ \\
\hline ohtc1c12 & 0.99577 & 0.00027 & $1.40 \mathrm{E}-01$ & htc1c12sen & 0.99400 & 0.00046 & $1.38 \mathrm{E}-01$ \\
\hline ohtc1c13 & 0.99491 & 0.000 & $2.71 \mathrm{E}-01$ & htc1c13 & 0.99113 & 0.00050 & $2.69 \mathrm{E}-01$ \\
\hline ohtc1c14 & 0.99400 & 0.00029 & $2.47 \mathrm{E}-01$ & htc1c14sen & 0.99064 & 0.00044 & $2.45 \mathrm{E}-01$ \\
\hline ohtc1c15 & 0.99368 & 0.00028 & $2.43 \mathrm{E}-01$ & htc1c15sen & 0.99138 & 0.00049 & $2.41 \mathrm{E}-01$ \\
\hline ohtc1c16 & 0.99630 & 0.00026 & $1.05 \mathrm{E}-01$ & htc1c16sen & 0.99618 & 0.00050 & $1.04 \mathrm{E}-01$ \\
\hline ohtc1c17 & 0.99592 & 0.00025 & $1.03 \mathrm{E}-01$ & htc1c17sen & 0.99582 & 0.00047 & $1.02 \mathrm{E}-01$ \\
\hline ohtc1c18 & 0.99435 & 0.00027 & $1.05 \mathrm{E}-01$ & htc1c18sen & 0.99333 & 0.00050 & $1.04 \mathrm{E}-01$ \\
\hline ohtc $2 \mathrm{~b} 01^{d}$ & 0.99504 & 0.00029 & $2.62 \mathrm{E}-01$ & htc2c1bsen & 0.99371 & 0.00047 & $2.58 \mathrm{E}-01$ \\
\hline ohtc $2 \mathrm{~b} 02^{d}$ & 0.99441 & 0.00029 & $2.58 \mathrm{E}-01$ & htc2c2bsen & 0.99215 & 0.00048 & $2.55 \mathrm{E}-01$ \\
\hline ohtc $2 \mathrm{~b} 03^{d}$ & 0.99471 & 0.00028 & $2.69 \mathrm{E}-01$ & htc2c3bsen & 0.99205 & 0.00050 & $2.67 \mathrm{E}-01$ \\
\hline ohtc2b04 & 0.99636 & 0.00028 & $2.78 \mathrm{E}-01$ & htc2c4bsen & 0.99410 & 0.00049 & $2.75 \mathrm{E}-01$ \\
\hline ohtc2b05 & 0.99657 & 0.00028 & & htc2c5bsen & 0.99404 & 0.00049 & $2.86 \mathrm{E}-01$ \\
\hline ohtc2b06 & 0.99640 & 0.00028 & $2.86 \mathrm{E}-01$ & htc2c6bsen & 0.99373 & 0.00043 & $2.83 \mathrm{E}-01$ \\
\hline ohtc2b07 & 0.99793 & 0.00027 & $2.95 \mathrm{E}-01$ & htc2c7bsen & 0.99456 & 0.00050 & $2.91 \mathrm{E}-01$ \\
\hline ohtc2b08 & 0.99737 & 0.00028 & $3.03 \mathrm{E}-01$ & htc2c8bsen & 0.99411 & 0.00047 & $2.99 \mathrm{E}-01$ \\
\hline ohtc2b09 & 0.99854 & 0.00027 & $1.73 \mathrm{E}-01$ & htc2c9bsen & 0.99713 & 0.00049 & $1.71 \mathrm{E}-01$ \\
\hline ohtc2b10 & 0.99635 & 0.00027 & $1.68 \mathrm{E}-01$ & htc2c10bsen & 0.99420 & 0.00047 & $1.66 \mathrm{E}-01$ \\
\hline ohtc2b11 & 0.99801 & 0.00026 & $1.63 \mathrm{E}-01$ & htc2c11bsen & 0.99593 & 0.00049 & $1.61 \mathrm{E}-01$ \\
\hline ohtc2b12 & 0.99773 & 0.00027 & $1.57 \mathrm{E}-01$ & htc2c12bsen & 0.99723 & 0.00046 & $1.54 \mathrm{E}-01$ \\
\hline ohtc2b13 & 0.99685 & 0.00027 & $1.51 \mathrm{E}-01$ & htc2c13bsen & 0.99447 & 0.00050 & $1.50 \mathrm{E}-01$ \\
\hline ohtc2b14 & 0.99940 & 0.00027 & $1.46 \mathrm{E}-01$ & htc2c14bsen & 0.99881 & 0.00050 & $1.45 \mathrm{E}-01$ \\
\hline ohtc2b15 & 1.00104 & 0.00027 & $1.07 \mathrm{E}-01$ & htc2c15bsen & 1.00017 & 0.00050 & $1.06 \mathrm{E}-01$ \\
\hline ohtc2b16 & 0.99925 & 0.00026 & $1.11 \mathrm{E}-01$ & htc2c16bsen & 0.99862 & 0.00050 & $1.10 \mathrm{E}-01$ \\
\hline ohtc2b17 & 1.00140 & 0.00024 & $1.15 \mathrm{E}-01$ & htc2c17bsen & 1.00013 & 0.00048 & $1.13 \mathrm{E}-01$ \\
\hline ohtc $2 \mathrm{~b} 18$ & 0.99222 & 0.00026 & $1.20 \mathrm{E}-01$ & htc2c18bsen & 0.99248 & 0.00050 & 1.19E-01 \\
\hline ohtc2b19 & 0.99717 & 0.00026 & $1.08 \mathrm{E}-01$ & htc2c19bsen & 0.99789 & 0.00049 & $1.07 \mathrm{E}-01$ \\
\hline
\end{tabular}


Table A-1. Criticality calculation results for HTC LCEs (continued)

\begin{tabular}{|c|c|c|c|c|c|c|c|}
\hline \multicolumn{8}{|c|}{$\begin{array}{c}\text { HTC } \\
\text { (Experimental } k_{\text {eff }}=\mathbf{1 . 0 0 0 0} \text { for all) }\end{array}$} \\
\hline \multicolumn{4}{|c|}{$\mathrm{MCNP}^{a}$} & \multicolumn{4}{|c|}{ SCALE $^{b}$} \\
\hline $\begin{array}{l}\text { Output } \\
\text { filename }\end{array}$ & $\boldsymbol{k}_{\text {eff }}$ & $\sigma$ & $\begin{array}{c}E A L F \\
(\mathrm{eV})\end{array}$ & Filename $^{c}$ & $\boldsymbol{k}_{\text {eff }}$ & $\sigma$ & $\begin{array}{c}E A L F \\
(\mathrm{eV})\end{array}$ \\
\hline ohtc2b20 & 0.99142 & 0.00025 & $9.27 \mathrm{E}-02$ & htc2c20bsen & 0.99245 & 0.00048 & $9.14 \mathrm{E}-02$ \\
\hline ohtc2b21 & 0.99481 & 0.00025 & $8.90 \mathrm{E}-02$ & htc2c21bsen & 0.99451 & 0.00048 & $8.79 \mathrm{E}-02$ \\
\hline ohtc2g01 & 0.99529 & 0.00029 & $2.67 \mathrm{E}-01$ & htc2c1gsen & 0.99267 & 0.00048 & $2.66 \mathrm{E}-01$ \\
\hline ohtc $2 \mathrm{~g} 02$ & 0.99460 & 0.00028 & $2.63 \mathrm{E}-01$ & htc2c2gsen & 0.99225 & 0.00046 & $2.59 \mathrm{E}-01$ \\
\hline ohtc $2 \mathrm{~g} 03$ & 0.99510 & 0.00029 & $2.85 \mathrm{E}-01$ & htc2c3gsen & 0.99275 & 0.00050 & $2.82 \mathrm{E}-01$ \\
\hline ohtc2g04 & 0.99485 & 0.00028 & $2.82 \mathrm{E}-01$ & htc2c4gsen & 0.99217 & 0.00050 & $2.79 \mathrm{E}-01$ \\
\hline ohtc $2 \mathrm{~g} 05$ & 0.99516 & 0.00028 & $2.77 \mathrm{E}-01$ & htc2c5gsen & 0.99303 & 0.00049 & $2.75 \mathrm{E}-01$ \\
\hline ohtc2g06 & 0.99464 & 0.00028 & $3.01 \mathrm{E}-01$ & htc2c6gsen & 0.99251 & 0.00050 & $2.98 \mathrm{E}-01$ \\
\hline ohtc2g07 & 0.99480 & 0.00028 & $2.93 \mathrm{E}-01$ & htc2c7gsen & 0.99179 & 0.00048 & $2.91 \mathrm{E}-01$ \\
\hline ohtc $2 \mathrm{~g} 08$ & 0.99504 & 0.00028 & $3.11 \mathrm{E}-01$ & htc2c8gsen & 0.99189 & 0.00049 & $3.08 \mathrm{E}-01$ \\
\hline ohtc2g09 & 0.99505 & 0.00028 & $3.08 \mathrm{E}-01$ & htc2c9gsen & 0.99191 & 0.00046 & $3.05 \mathrm{E}-01$ \\
\hline ohtc $2 \mathrm{~g} 10$ & 0.99587 & 0.00027 & $1.77 \mathrm{E}-01$ & htc2c10gsen & 0.99389 & 0.00049 & $1.75 \mathrm{E}-01$ \\
\hline ohtc2g11 & 0.99643 & 0.00027 & $1.69 \mathrm{E}-01$ & htc2c11gsen & 0.99459 & 0.00049 & $1.67 \mathrm{E}-01$ \\
\hline ohtc $2 \mathrm{~g} 12$ & 0.99598 & 0.00027 & $1.68 \mathrm{E}-01$ & htc2c1 & 0.99559 & 0.00050 & \\
\hline ohtc $2 \mathrm{~g} 13$ & 0.99619 & 0.00027 & $1.61 \mathrm{E}-01$ & htc2c13gsen & 0.99500 & 0.00046 & $1.59 \mathrm{E}-01$ \\
\hline ohtc $2 \mathrm{~g} 14$ & 0.99662 & 0.00027 & $1.59 \mathrm{E}-01$ & htc2c14gsen & 0.99528 & 0.00049 & $1.57 \mathrm{E}-01$ \\
\hline ohtc $2 \mathrm{~g} 15$ & 0.99732 & 0.00028 & $1.54 \mathrm{E}-01$ & htc2c15gsen & 0.99505 & 0.00049 & $1.52 \mathrm{E}-01$ \\
\hline ohtc2g16 & 0.99747 & 0.00028 & $1.50 \mathrm{E}-01$ & htc2c16gsen & 0.99526 & 0.00049 & $1.49 \mathrm{E}-01$ \\
\hline ohtc $2 \mathrm{~g} 17$ & 0.99790 & 0.00026 & $1.10 \mathrm{E}-01$ & htc2c17gsen & 0.99733 & 0.00048 & $1.09 \mathrm{E}-01$ \\
\hline ohtc $2 \mathrm{~g} 18$ & 0.99904 & 0.00025 & $9.08 \mathrm{E}-02$ & htc2c18gsen & 0.99867 & 0.00050 & $8.98 \mathrm{E}-02$ \\
\hline ohtc $2 \mathrm{~g} 19$ & 0.99574 & 0.00026 & $1.18 \mathrm{E}-01$ & htc2c19gsen & 0.99416 & 0.00049 & $1.17 \mathrm{E}-01$ \\
\hline ohtc2g20 & 0.99806 & 0.00025 & $1.10 \mathrm{E}-01$ & htc2c20gsen & 0.99641 & 0.00049 & $1.10 \mathrm{E}-01$ \\
\hline ohtc $3 \mathrm{c} 01$ & 0.99553 & 0.00028 & $1.29 \mathrm{E}-01$ & htc3c1sen & 0.99412 & 0.00048 & $1.27 \mathrm{E}-01$ \\
\hline ohtc $3 \mathrm{c} 03$ & 0.99564 & 0.00028 & $1.35 \mathrm{E}-01$ & htc3c3sen & 0.99504 & 0.00050 & $1.33 \mathrm{E}-01$ \\
\hline ohtc $3 \mathrm{c} 04$ & 0.99547 & 0.00027 & $1.29 \mathrm{E}-01$ & htc $3 \mathrm{c} 4 \mathrm{sen}$ & 0.99545 & 0.00049 & $1.27 \mathrm{E}-01$ \\
\hline ohtc $3 \mathrm{c} 05$ & 0.99469 & 0.00027 & $1.41 \mathrm{E}-01$ & htc3c5sen & 0.99498 & 0.00050 & $1.39 \mathrm{E}-01$ \\
\hline ohtc3c07 & 0.99378 & 0.00028 & $1.34 \mathrm{E}-01$ & htc3c7sen & 0.99187 & 0.00048 & $1.32 \mathrm{E}-01$ \\
\hline ohtc3c09 & 0.99375 & 0.00027 & $1.39 \mathrm{E}-01$ & htc3c9sen & 0.99454 & 0.00047 & $1.37 \mathrm{E}-01$ \\
\hline ohtc $3 \mathrm{c} 10$ & 0.99468 & 0.00026 & $1.35 \mathrm{E}-01$ & htc3c10sen & 0.99484 & 0.00050 & $1.33 \mathrm{E}-01$ \\
\hline ohtc $3 \mathrm{c} 11$ & 0.99358 & 0.00027 & $1.43 \mathrm{E}-01$ & htc3c11sen & 0.99394 & 0.00053 & $1.41 \mathrm{E}-01$ \\
\hline ohtc $3 \mathrm{c} 12$ & 0.99568 & 0.00027 & $1.17 \mathrm{E}-01$ & htc3c12sen & 0.99576 & 0.00045 & $1.16 \mathrm{E}-01$ \\
\hline ohtc $3 \mathrm{c} 13$ & 0.99650 & 0.00026 & $1.16 \mathrm{E}-01$ & htc3c13sen & 0.99584 & 0.00049 & $1.15 \mathrm{E}-01$ \\
\hline ohtc $3 \mathrm{c} 14$ & 0.99644 & 0.00027 & $1.16 \mathrm{E}-01$ & htc3c14sen & 0.99501 & 0.00049 & $1.15 \mathrm{E}-01$ \\
\hline ohtc $3 \mathrm{c} 15$ & 0.99616 & 0.00025 & $1.15 \mathrm{E}-01$ & htc3c15sen & 0.99421 & 0.00044 & $1.14 \mathrm{E}-01$ \\
\hline ohtc $3 \mathrm{c} 16$ & 0.99650 & 0.00026 & $1.15 \mathrm{E}-01$ & htc3c16sen & 0.99476 & 0.00050 & $1.14 \mathrm{E}-01$ \\
\hline ohtc3c17 & 0.99571 & 0.00026 & $1.13 \mathrm{E}-01$ & htc3c17sen & 0.99525 & 0.00050 & $1.11 \mathrm{E}-01$ \\
\hline ohtc $3 \mathrm{c} 18$ & 0.99547 & 0.00027 & $1.11 \mathrm{E}-01$ & htc3c18sen & 0.99543 & 0.00050 & $1.10 \mathrm{E}-01$ \\
\hline ohtc $3 \mathrm{c} 19$ & 0.99684 & 0.00026 & $1.08 \mathrm{E}-01$ & htc3c19sen & 0.99530 & 0.00049 & $1.07 \mathrm{E}-01$ \\
\hline ohtc 3 c20 & 0.99639 & 0.00025 & $1.06 \mathrm{E}-01$ & htc3c20sen & 0.99538 & 0.00049 & $1.05 \mathrm{E}-01$ \\
\hline ohtc $3 \mathrm{c} 21$ & 0.99635 & 0.00026 & $1.09 \mathrm{E}-01$ & htc3c21sen & 0.99654 & 0.00045 & $1.07 \mathrm{E}-01$ \\
\hline ohtc $3 \mathrm{c} 22$ & 0.99730 & 0.00026 & $1.11 \mathrm{E}-01$ & htc $3 \mathrm{c} 22 \mathrm{sen}$ & 0.99653 & 0.00049 & $1.10 \mathrm{E}-01$ \\
\hline ohtc $3 \mathrm{c} 23$ & 0.99519 & 0.00027 & $1.20 \mathrm{E}-01$ & htc3c23sen & 0.99555 & 0.00049 & $1.19 \mathrm{E}-01$ \\
\hline
\end{tabular}


Table A-1. Criticality calculation results for HTC LCEs (continued)

\begin{tabular}{|c|c|c|c|c|c|c|c|}
\hline \multicolumn{8}{|c|}{$\begin{array}{c}\text { HTC } \\
\text { (Experimental } k_{\text {eff }}=\mathbf{1 . 0 0 0 0} \text { for all) }\end{array}$} \\
\hline \multicolumn{4}{|c|}{$\mathbf{M C N P}^{a}$} & \multicolumn{4}{|c|}{ SCALE $^{b}$} \\
\hline $\begin{array}{c}\text { Output } \\
\text { filename }\end{array}$ & $\boldsymbol{k}_{\text {eff }}$ & $\sigma$ & $\begin{array}{c}E A L F \\
(\mathrm{eV})\end{array}$ & Filename $^{c}$ & $\boldsymbol{k}_{\text {eff }}$ & $\sigma$ & $\begin{array}{c}E A L F \\
(\mathrm{eV}) \\
\end{array}$ \\
\hline ohtc3c24 & 0.99565 & 0.00026 & $1.58 \mathrm{E}-01$ & htc3c24sen & 0.99514 & 0.00046 & $1.58 \mathrm{E}-01$ \\
\hline ohtc $3 \mathrm{c} 25$ & 0.99614 & 0.00026 & $1.32 \mathrm{E}-01$ & htc $3 \mathrm{c} 25 \mathrm{sen}$ & 0.99498 & 0.00049 & $1.32 \mathrm{E}-01$ \\
\hline ohtc $3 \mathrm{c} 26$ & 0.99560 & 0.00026 & $1.20 \mathrm{E}-01$ & htc3c26sen & 0.99612 & 0.00050 & $1.19 \mathrm{E}-01$ \\
\hline ohtc4102 & 0.99809 & 0.00027 & $1.55 \mathrm{E}-01$ & htc4pb02sen & 0.99686 & 0.00049 & $1.55 \mathrm{E}-01$ \\
\hline ohtc4103 & 0.99774 & 0.00026 & $1.51 \mathrm{E}-01$ & htc 4 pb03sen & 0.99656 & 0.00050 & $1.50 \mathrm{E}-01$ \\
\hline ohtc4104 & 0.99822 & 0.00026 & $1.48 \mathrm{E}-01$ & htc4pb04sen & 0.99647 & 0.00050 & $1.47 \mathrm{E}-01$ \\
\hline ohtc4105 & 0.99784 & 0.00026 & $1.44 \mathrm{E}-01$ & htc $4 \mathrm{pb} 05$ sen & 0.99645 & 0.00043 & $1.44 \mathrm{E}-01$ \\
\hline ohtc4106 & 0.99809 & 0.00027 & $1.39 \mathrm{E}-01$ & htc4pb06sen & 0.99653 & 0.00048 & $1.38 \mathrm{E}-01$ \\
\hline ohtc4107 & 0.99833 & 0.00027 & $1.37 \mathrm{E}-01$ & htc4pb07sen & 0.99699 & 0.00048 & $1.36 \mathrm{E}-01$ \\
\hline ohtc4108 & 0.99693 & 0.00026 & $1.43 \mathrm{E}-01$ & htc4pb08sen & 0.99499 & 0.00050 & $1.42 \mathrm{E}-01$ \\
\hline ohtc4109 & 0.99629 & 0.00026 & $1.42 \mathrm{E}-01$ & htc4pb09sen & 0.99445 & 0.00050 & $1.42 \mathrm{E}-01$ \\
\hline ohtc4110 & 0.99627 & 0.00027 & $1.41 \mathrm{E}-01$ & htc4pb10sen & 0.99491 & 0.00044 & $1.40 \mathrm{E}-01$ \\
\hline ohtc4l11 & 0.99602 & 0.00027 & $1.40 \mathrm{E}-01$ & htc4pb11sen & 0.99495 & 0.00049 & $1.39 \mathrm{E}-01$ \\
\hline ohtc4115 & 0.99605 & 0.00028 & $1.35 \mathrm{E}-01$ & htc 4 pb15sen & 0.99381 & 0.00049 & $1.34 \mathrm{E}-01$ \\
\hline ohtc4116 & 0.99569 & 0.00027 & $1.38 \mathrm{E}-01$ & htc4pb16sen & 0.99513 & 0.00050 & $1.37 \mathrm{E}-01$ \\
\hline ohtc4118 & 0.99714 & 0.00027 & $1.48 \mathrm{E}-01$ & htc4pb18sen & 0.99476 & 0.00049 & $1.47 \mathrm{E}-01$ \\
\hline ohtc4119 & 0.99812 & 0.00027 & $1.41 \mathrm{E}-01$ & htc4pb19sen & 0.99453 & 0.00048 & $1.40 \mathrm{E}-01$ \\
\hline ohtc4120 & 0.99855 & 0.00027 & $1.38 \mathrm{E}-01$ & htc4pb20sen & 0.99440 & 0.00049 & $1.37 \mathrm{E}-01$ \\
\hline ohtc4121 & 0.99620 & 0.00027 & $1.40 \mathrm{E}-01$ & htc 4 pb21sen & 0.99247 & 0.00050 & $1.39 \mathrm{E}-01$ \\
\hline ohtc4122 & 0.99539 & 0.00027 & $1.39 \mathrm{E}-01$ & htc4pb22sen & 0.99250 & 0.00050 & $1.38 \mathrm{E}-01$ \\
\hline ohtc4123 & 0.99481 & 0.00027 & $1.37 \mathrm{E}-01$ & htc4pb23sen & 0.99244 & 0.00049 & $1.37 \mathrm{E}-01$ \\
\hline ohtc4124 & 0.99489 & 0.00027 & $1.37 \mathrm{E}-01$ & htc4pb24sen & 0.99138 & 0.00049 & $1.35 \mathrm{E}-01$ \\
\hline ohtc4125 & 0.99835 & 0.00027 & $1.35 \mathrm{E}-01$ & htc4pb25sen & 0.99580 & 0.00049 & $1.34 \mathrm{E}-01$ \\
\hline ohtc4126 & 0.99861 & 0.00027 & $1.32 \mathrm{E}-01$ & htc4pb26sen & 0.99556 & 0.00050 & $1.32 \mathrm{E}-01$ \\
\hline ohtc4127 & 0.99803 & 0.00027 & $1.81 \mathrm{E}-01$ & htc4pb27sen & 0.99775 & 0.00050 & $1.82 \mathrm{E}-01$ \\
\hline ohtc4128 & 0.99841 & 0.00026 & $1.73 \mathrm{E}-01$ & htc4pb28sen & 0.99828 & 0.00048 & $1.74 \mathrm{E}-01$ \\
\hline ohtc4129 & 0.99826 & 0.00026 & $1.64 \mathrm{E}-01$ & htc4pb29sen & 0.99598 & 0.00049 & $1.65 \mathrm{E}-01$ \\
\hline ohtc4130 & 0.99854 & 0.00026 & $1.50 \mathrm{E}-01$ & htc4pb30sen & 0.99786 & 0.00050 & $1.50 \mathrm{E}-01$ \\
\hline ohtc4131 & 0.99831 & 0.00026 & $1.40 \mathrm{E}-01$ & htc4pb31sen & 0.99750 & 0.00049 & $1.39 \mathrm{E}-01$ \\
\hline ohtc4132 & 0.99915 & 0.00026 & $1.33 \mathrm{E}-01$ & htc4pb32sen & 0.99817 & 0.00050 & $1.34 \mathrm{E}-01$ \\
\hline ohtc4133 & 0.99884 & 0.00026 & $1.30 \mathrm{E}-01$ & htc4pb33sen & 0.99843 & 0.00045 & $1.29 \mathrm{E}-01$ \\
\hline ohtc4134 & 0.99948 & 0.00026 & $1.28 \mathrm{E}-01$ & htc4pb34sen & 0.99753 & 0.00050 & $1.27 \mathrm{E}-01$ \\
\hline ohtc4135 & 0.99791 & 0.00025 & $1.63 \mathrm{E}-01$ & htc4pb35sen & 0.99702 & 0.00049 & $1.63 \mathrm{E}-01$ \\
\hline ohtc4136 & 0.99776 & 0.00026 & $1.62 \mathrm{E}-01$ & htc4pb36sen & 0.99784 & 0.00047 & $1.62 \mathrm{E}-01$ \\
\hline ohtc4137 & 0.99817 & 0.00026 & $1.60 \mathrm{E}-01$ & htc4pb37sen & 0.99709 & 0.00049 & $1.61 \mathrm{E}-01$ \\
\hline ohtc4138 & 0.99788 & 0.00026 & $1.59 \mathrm{E}-01$ & htc4pb38sen & 0.99774 & 0.00048 & $1.60 \mathrm{E}-01$ \\
\hline ohtc $4 \mathrm{~s} 02$ & 0.99601 & 0.00026 & $1.56 \mathrm{E}-01$ & htc4ss02sen & 0.99579 & 0.00049 & $1.55 \mathrm{E}-01$ \\
\hline ohtc4s03 & 0.99607 & 0.00026 & $1.52 \mathrm{E}-01$ & htc 4 ss 03 sen & 0.99372 & 0.00049 & $1.52 \mathrm{E}-01$ \\
\hline ohtc4s04 & 0.99620 & 0.00027 & $1.48 \mathrm{E}-01$ & htc 4 ss 04 sen & 0.99568 & 0.00049 & $1.48 \mathrm{E}-01$ \\
\hline ohtc $4 \mathrm{~s} 05$ & 0.99614 & 0.00027 & $1.45 \mathrm{E}-01$ & htc 4 ss 05 sen & 0.99567 & 0.00048 & $1.44 \mathrm{E}-01$ \\
\hline ohtc 4 s06 & 0.99446 & 0.00027 & $1.44 \mathrm{E}-01$ & htc 4 ss 06 sen & 0.99440 & 0.00045 & $1.44 \mathrm{E}-01$ \\
\hline
\end{tabular}


Table A-1. Criticality calculation results for HTC LCEs (continued)

\begin{tabular}{|c|c|c|c|c|c|c|c|}
\hline \multicolumn{8}{|c|}{$\begin{array}{c}\text { HTC } \\
\text { (Experimental } k_{\text {eff }}=\mathbf{1 . 0 0 0 0} \text { for all) }\end{array}$} \\
\hline \multicolumn{4}{|c|}{ MCNP $^{a}$} & \multicolumn{4}{|c|}{ SCALE $^{b}$} \\
\hline $\begin{array}{c}\text { Output } \\
\text { filename }\end{array}$ & $\boldsymbol{k}_{\text {eff }}$ & $\sigma$ & $\begin{array}{c}E A L F \\
(\mathrm{eV})\end{array}$ & Filename $^{c}$ & $\boldsymbol{k}_{\text {eff }}$ & $\sigma$ & $\begin{array}{c}E A L F \\
(\mathrm{eV})\end{array}$ \\
\hline ohtc4s07 & 0.99401 & 0.00027 & $1.43 \mathrm{E}-01$ & htc4ss07sen & 0.99341 & 0.00048 & $1.42 \mathrm{E}-01$ \\
\hline ohtc4s08 & 0.99415 & 0.00027 & $1.42 \mathrm{E}-01$ & htc 4 ss 08 sen & 0.99316 & 0.00049 & $1.41 \mathrm{E}-01$ \\
\hline ohtc4s09 & 0.99380 & 0.00027 & $1.41 \mathrm{E}-01$ & htc4ss09sen & 0.99294 & 0.00049 & $1.40 \mathrm{E}-01$ \\
\hline ohtc $4 \mathrm{~s} 10$ & 0.99562 & 0.00027 & $1.40 \mathrm{E}-01$ & htc4ss10sen & 0.99543 & 0.00046 & $1.39 \mathrm{E}-01$ \\
\hline ohtc4s11 & 0.99596 & 0.00028 & $1.38 \mathrm{E}-01$ & htc4ss11sen & 0.99426 & 0.00049 & $1.37 \mathrm{E}-01$ \\
\hline ohtc4s13 & 0.99455 & 0.00026 & $1.39 \mathrm{E}-01$ & htc4ss13sen & 0.99389 & 0.00049 & $1.38 \mathrm{E}-01$ \\
\hline ohtc4s 15 & 0.99461 & 0.00026 & $1.49 \mathrm{E}-01$ & htc 4 ss 15 sen & 0.99203 & 0.00050 & $1.49 \mathrm{E}-01$ \\
\hline ohtc $4 \mathrm{~s} 16$ & 0.99479 & 0.00026 & $1.42 \mathrm{E}-01$ & htc4ss16sen & 0.99275 & 0.00050 & $1.42 \mathrm{E}-01$ \\
\hline ohtc4s17 & 0.99340 & 0.00026 & $1.41 \mathrm{E}-01$ & htc4ss17sen & 0.99172 & 0.00049 & $1.41 \mathrm{E}-01$ \\
\hline ohtc4s18 & 0.99235 & 0.00026 & $1.39 \mathrm{E}-01$ & htc4ss18sen & 0.99014 & 0.00050 & $1.39 \mathrm{E}-01$ \\
\hline ohtc 4 s19 & 0.99280 & 0.00027 & $1.38 \mathrm{E}-01$ & htc4ss19sen & 0.99054 & 0.00050 & $1.37 \mathrm{E}-01$ \\
\hline ohtc $4 \mathrm{~s} 20$ & 0.99191 & 0.00027 & $1.38 \mathrm{E}-01$ & htc 4 ss 20 sen & 0.98996 & 0.00050 & $1.37 \mathrm{E}-01$ \\
\hline ohtc4s21 & 0.99572 & 0.00027 & $1.39 \mathrm{E}-01$ & htc4ss21sen & 0.99363 & 0.00050 & $1.38 \mathrm{E}-01$ \\
\hline ohtc $4 \mathrm{~s} 22$ & 0.99674 & 0.00026 & $1.82 \mathrm{E}-01$ & htc4ss22sen & 0.99805 & 0.00048 & $1.83 \mathrm{E}-01$ \\
\hline ohtc4s 23 & 0.99721 & 0.00027 & $1.73 \mathrm{E}-01$ & htc 4 ss 23 sen & 0.99768 & 0.00049 & $1.73 \mathrm{E}-01$ \\
\hline ohtc4s24 & 0.99549 & 0.00025 & $1.64 \mathrm{E}-01$ & htc4ss24sen & 0.99663 & 0.00049 & $1.65 \mathrm{E}-01$ \\
\hline ohtc4s25 & 0.99578 & 0.00027 & $1.63 \mathrm{E}-01$ & htc4ss25sen & 0.99619 & 0.00040 & $1.63 \mathrm{E}-01$ \\
\hline ohtc $4 \mathrm{~s} 26$ & 0.99580 & 0.00027 & $1.61 \mathrm{E}-01$ & htc4ss26sen & 0.99655 & 0.00049 & $1.62 \mathrm{E}-01$ \\
\hline ohtc4s 27 & 0.99634 & 0.00026 & $1.60 \mathrm{E}-01$ & htc4ss 27 sen & 0.99657 & 0.00049 & $1.61 \mathrm{E}-01$ \\
\hline ohtc4s 28 & 0.99603 & 0.00026 & $1.59 \mathrm{E}-01$ & htc 4 ss 28 sen & 0.99626 & 0.00050 & $1.60 \mathrm{E}-01$ \\
\hline ohtc4s29 & 0.99556 & 0.00026 & $1.49 \mathrm{E}-01$ & htc4ss29sen & 0.99601 & 0.00046 & $1.49 \mathrm{E}-01$ \\
\hline ohtc4s30 & 0.99611 & 0.00025 & $1.39 \mathrm{E}-01$ & htc4ss30sen & 0.99682 & 0.00049 & $1.38 \mathrm{E}-01$ \\
\hline ohtc $4 \mathrm{~s} 31$ & 0.99551 & 0.00026 & $1.33 \mathrm{E}-01$ & htc 4 ss 31 sen & 0.99566 & 0.00050 & $1.32 \mathrm{E}-01$ \\
\hline ohtc4s32 & 0.99619 & 0.00027 & $1.29 \mathrm{E}-01$ & htc4ss32sen & 0.99610 & 0.00050 & $1.28 \mathrm{E}-01$ \\
\hline ohtc4s33 & 0.99582 & 0.00026 & $1.27 \mathrm{E}-01$ & htc4ss33sen & 0.99702 & 0.00049 & $1.26 \mathrm{E}-01$ \\
\hline
\end{tabular}

The input and output files are included in the DVD attachment, paths:

${ }^{a} \mathrm{DVD} / \mathrm{exp} / \mathrm{htc} / \mathrm{mcnp}$.

${ }^{b} \mathrm{DVD} / \mathrm{exp} / \mathrm{htc} / \mathrm{sens}$.

${ }^{c}$ Output file name is Filename.output.

${ }^{d}$ The results were obtained with MCNP jobs from CPILE2. 
Table A-2. Criticality calculation results for MOX LCES

\begin{tabular}{|c|c|c|c|c|c|c|c|c|}
\hline \multicolumn{4}{|c|}{$\operatorname{MCNP}^{a}$} & \multicolumn{4}{|c|}{ SCALE $^{b}$} & \multirow[b]{2}{*}{$\begin{array}{c}\text { Experimental } \\
k_{\text {eff }} \\
\end{array}$} \\
\hline $\begin{array}{c}\text { Output } \\
\text { filename }\end{array}$ & $\boldsymbol{k}_{\text {eff }}$ & $\sigma$ & $\begin{array}{c}\text { EALF } \\
(\mathrm{eV})\end{array}$ & Filename $^{c}$ & $\boldsymbol{k}_{\text {eff }}$ & $\sigma$ & $\begin{array}{c}E A L F \\
(\mathrm{eV})\end{array}$ & \\
\hline $\operatorname{oct} 02-01$ & 0.99306 & 0.00038 & $5.78 \mathrm{E}-01$ & mct002-01sen & 0.99118 & 0.00027 & $5.69 \mathrm{E}-01$ & 1.0010 \\
\hline oct02-02 & 0.99577 & 0.00036 & $7.65 \mathrm{E}-01$ & mct002-02sen & 0.99320 & 0.00029 & $7.57 \mathrm{E}-01$ & 1.0009 \\
\hline oct02-03 & 0.99648 & 0.00028 & $1.94 \mathrm{E}-01$ & mct002-03sen & 0.99642 & 0.00026 & $1.90 \mathrm{E}-01$ & 1.0024 \\
\hline oct02-04 & 1.00277 & 0.00037 & $2.83 \mathrm{E}-01$ & mct002-04sen & 1.00145 & 0.00024 & $2.77 \mathrm{E}-01$ & 1.0024 \\
\hline oct02-05 & 0.99853 & 0.00037 & $1.39 \mathrm{E}-01$ & mct002-05sen & 1.00021 & 0.00026 & $1.36 \mathrm{E}-01$ & 1.0038 \\
\hline oct02-06 & 1.00289 & 0.00025 & $1.84 \mathrm{E}-01$ & mct002-06sen & 1.00216 & 0.00022 & $1.80 \mathrm{E}-01$ & 1.0029 \\
\hline oct03-01 & 0.99334 & 0.00041 & $8.89 \mathrm{E}-01$ & mct003-01sen & 0.99161 & 0.00028 & $8.87 \mathrm{E}-01$ & 1.0000 \\
\hline oct03-02 & 0.99478 & 0.00042 & $5.43 \mathrm{E}-01$ & mct003-02sen & 0.99278 & 0.00028 & $5.37 \mathrm{E}-01$ & 1.0000 \\
\hline oct03-03 & 0.99444 & 0.00042 & $6.42 \mathrm{E}-01$ & mct003-03sen & 0.99214 & 0.00034 & $6.39 \mathrm{E}-01$ & 1.0000 \\
\hline oct03-04 & 0.99560 & 0.00041 & $1.88 \mathrm{E}-01$ & mct003-04sen & 0.99484 & 0.00032 & $1.85 \mathrm{E}-01$ & 1.0000 \\
\hline oct03-05 & 0.99527 & 0.00039 & $1.56 \mathrm{E}-01$ & mct003-05sen & 0.99559 & 0.00026 & $1.53 \mathrm{E}-01$ & 1.0000 \\
\hline oct03-06 & 0.99861 & 0.00038 & $1.02 \mathrm{E}-01$ & mct003-06sen & 0.99726 & 0.00025 & 9.99E-02 & 1.0000 \\
\hline oct04-01 & 0.99122 & 0.00036 & $1.46 \mathrm{E}-01$ & mct004-01sen & 0.99132 & 0.00025 & $1.44 \mathrm{E}-01$ & 1.0000 \\
\hline oct06-01 & 0.99089 & 0.00037 & $3.76 \mathrm{E}-01$ & mct006-01sen & 0.98895 & 0.00026 & $3.70 \mathrm{E}-01$ & 1.0016 \\
\hline oct07-02 & 0.99400 & 0.00034 & $1.43 \mathrm{E}-01$ & mct007-02sen & 0.99428 & 0.00026 & $1.39 \mathrm{E}-01$ & 1.0024 \\
\hline oct $08-01$ & 0.99223 & 0.00036 & $3.99 \mathrm{E}-01$ & met008-01sen & 0.99021 & 0.00028 & $3.92 \mathrm{E}-01$ & 0.9997 \\
\hline oct08-02 & 0.99464 & 0.00035 & $2.00 \mathrm{E}-01$ & mct008-02sen & 0.99277 & 0.00024 & $1.96 \mathrm{E}-01$ & 1.0008 \\
\hline oct08-03 & 0.99481 & 0.00034 & $1.43 \mathrm{E}-01$ & mct008-03sen & 0.99445 & 0.00023 & $1.40 \mathrm{E}-01$ & 1.0023 \\
\hline oct08-04 & 0.99693 & 0.00033 & $1.21 \mathrm{E}-01$ & mct008-04sen & 0.99840 & 0.00024 & $1.18 \mathrm{E}-01$ & 1.0015 \\
\hline oct08-05 & 0.99869 & 0.00030 & $9.81 \mathrm{E}-02$ & mct008-05sen & 0.99891 & 0.00025 & $9.60 \mathrm{E}-02$ & 1.0022 \\
\hline oct08-06 & 0.99813 & 0.00028 & $9.30 \mathrm{E}-02$ & mct008-06sen & 0.99906 & 0.00019 & $9.09 \mathrm{E}-02$ & 1.0028 \\
\hline ost01-01 & 0.99226 & 0.00043 & $1.60 \mathrm{E}-01$ & mst001-01sen & 0.99537 & 0.00031 & $1.57 \mathrm{E}-01$ & 1.0000 \\
\hline ost01-02 & 0.99159 & 0.00044 & $1.61 \mathrm{E}-01$ & mst001-02sen & 0.99537 & 0.00027 & $1.58 \mathrm{E}-01$ & 1.0000 \\
\hline ost01-03 & 0.98652 & 0.00046 & $1.57 \mathrm{E}-01$ & mst001-03sen & 0.99043 & 0.00029 & $1.54 \mathrm{E}-01$ & 1.0000 \\
\hline ost01-04 & 0.99165 & 0.00044 & $1.70 \mathrm{E}-01$ & mst001-04sen & 0.99486 & 0.00029 & $1.66 \mathrm{E}-01$ & 1.0000 \\
\hline ost01-05 & 0.99500 & 0.00044 & $1.75 \mathrm{E}-01$ & mst001-05sen & 0.99920 & 0.00032 & $1.71 \mathrm{E}-01$ & 1.0000 \\
\hline ost01-06 & 0.99587 & 0.00045 & $1.68 \mathrm{E}-01$ & mst001-06sen & 0.99813 & 0.00028 & $1.65 \mathrm{E}-01$ & 1.0000 \\
\hline ost01-08 & 0.99688 & 0.00045 & $1.48 \mathrm{E}-01$ & mst001-08sen & 1.00067 & 0.00032 & $1.46 \mathrm{E}-01$ & 1.0000 \\
\hline ost01-09 & 0.99812 & 0.00043 & $9.18 \mathrm{E}-02$ & mst001-09sen & 1.00029 & 0.00028 & $9.07 \mathrm{E}-02$ & 1.0000 \\
\hline ost01-10 & 0.99742 & 0.00043 & $1.15 \mathrm{E}-01$ & mst001-10sen & 1.00061 & 0.00027 & $1.13 \mathrm{E}-01$ & 1.0000 \\
\hline ost01-11 & 1.00296 & 0.00041 & $1.11 \mathrm{E}-01$ & mst001-11sen & 1.00552 & 0.00031 & $1.09 \mathrm{E}-01$ & 1.0000 \\
\hline ost01-12 & 1.00445 & 0.00043 & 1.09E-01 & mst001-12sen & 1.00622 & 0.00025 & $1.07 \mathrm{E}-01$ & 1.0000 \\
\hline ost01-13 & 0.99526 & 0.00041 & $8.37 \mathrm{E}-02$ & mst001-13sen & 0.99742 & 0.00025 & $8.24 \mathrm{E}-02$ & 1.0000 \\
\hline ost02-01 & 1.00188 & 0.00025 & 4.22E-02 & mst002-01sen & 1.00399 & 0.00021 & $4.20 \mathrm{E}-02$ & 1.0000 \\
\hline ost02-02 & 1.00209 & 0.00024 & $4.21 \mathrm{E}-02$ & mst002-02sen & 1.00412 & 0.00023 & $4.19 \mathrm{E}-02$ & 1.0000 \\
\hline ost02-03 & 1.00171 & 0.00027 & 4.32E-02 & mst002-03sen & 1.00373 & 0.00021 & $4.29 \mathrm{E}-02$ & 1.0000 \\
\hline ost04-01 & 0.99716 & 0.00045 & 7.10E-02 & mst004-01sen & 0.99796 & 0.00032 & 7.02E-02 & 1.0000 \\
\hline ost04-02 & 0.99566 & 0.00043 & $6.71 \mathrm{E}-02$ & mst004-02sen & 0.99753 & 0.00029 & $6.63 \mathrm{E}-02$ & 1.0000 \\
\hline ost04-03 & 0.99731 & 0.00043 & 6.97E-02 & mst004-03sen & 1.00017 & 0.00035 & $6.88 \mathrm{E}-02$ & 1.0000 \\
\hline ost04-04 & 0.99838 & 0.00046 & $1.75 \mathrm{E}-01$ & mst004-04sen & 1.00123 & 0.00029 & $1.72 \mathrm{E}-01$ & 1.0000 \\
\hline ost04-05 & 0.99277 & 0.00047 & $1.59 \mathrm{E}-01$ & mst004-05sen & 0.99561 & 0.00034 & $1.56 \mathrm{E}-01$ & 1.0000 \\
\hline ost04-06 & 0.99314 & 0.00049 & $1.91 \mathrm{E}-01$ & mst004-06sen & 0.99588 & 0.00035 & $1.88 \mathrm{E}-01$ & 1.0000 \\
\hline ost04-07 & 0.99472 & 0.00049 & $3.51 \mathrm{E}-01$ & mst004-07sen & 0.99696 & 0.00029 & $3.42 \mathrm{E}-01$ & 1.0000 \\
\hline
\end{tabular}


Table A-2. Criticality calculation results for MOX LCEs (continued)

\begin{tabular}{|c|c|c|c|c|c|c|c|c|}
\hline \multicolumn{4}{|c|}{ MCNP $^{a}$} & \multicolumn{4}{|c|}{ SCALE $^{b}$} & \multirow[b]{2}{*}{$\begin{array}{c}\text { Experimental } \\
k_{\text {eff }} \\
\end{array}$} \\
\hline $\begin{array}{c}\text { Output } \\
\text { filename }\end{array}$ & $\boldsymbol{k}_{\text {eff }}$ & $\sigma$ & $\begin{array}{l}E A L F \\
(\mathrm{eV})\end{array}$ & Filename $^{c}$ & $\boldsymbol{k}_{\text {eff }}$ & $\sigma$ & $\begin{array}{c}E A L F \\
(\mathrm{eV})\end{array}$ & \\
\hline ost04-08 & 0.99256 & 0.00047 & $2.65 \mathrm{E}-01$ & mst004-08sen & 0.99632 & 0.00032 & $2.60 \mathrm{E}-01$ & 1.0000 \\
\hline ost04-09 & 0.99484 & 0.00047 & $3.07 \mathrm{E}-01$ & mst004-09sen & 0.99778 & 0.00030 & $3.00 \mathrm{E}-01$ & 1.0000 \\
\hline ost05-01 & 0.99423 & 0.00045 & 7.09E-02 & mst005-01sen & 0.99390 & 0.00032 & 6.99E-02 & 1.0000 \\
\hline ost05-02 & 0.99848 & 0.00040 & $6.66 \mathrm{E}-02$ & mst005-02sen & 0.99984 & 0.00028 & $6.57 \mathrm{E}-02$ & 1.0000 \\
\hline ost05-03 & 0.99742 & 0.00047 & $1.54 \mathrm{E}-01$ & mst005-03sen & 1.00009 & 0.00029 & $1.51 \mathrm{E}-01$ & 1.0000 \\
\hline ost05-04 & 0.99619 & 0.00043 & $1.52 \mathrm{E}-01$ & mst005-04sen & 0.99855 & 0.00032 & $1.49 \mathrm{E}-01$ & 1.0000 \\
\hline ost05-05 & 0.98608 & 0.00047 & $1.94 \mathrm{E}-01$ & mst005-05sen & 0.98815 & 0.00032 & $1.89 \mathrm{E}-01$ & 1.0000 \\
\hline ost05-06 & 0.98564 & 0.00047 & $3.53 \mathrm{E}-01$ & mst005-06sen & 0.98830 & 0.00033 & $3.44 \mathrm{E}-01$ & 1.0000 \\
\hline ost05-07 & 0.99274 & 0.00045 & $2.53 \mathrm{E}-01$ & mst005-07sen & 0.99665 & 0.00030 & $2.47 \mathrm{E}-01$ & 1.0000 \\
\hline
\end{tabular}

The input and output files are included in the DVD attachment, paths:

${ }^{a} \mathrm{DVD} / \mathrm{exp} / \mathrm{mox} / \mathrm{mcnp}$.

${ }^{b} \mathrm{DVD} / \mathrm{exp} / \mathrm{mox} / \mathrm{sens}$.

${ }^{c}$ Output file name is Filename.output. 
Table A-3. Criticality calculation results for LEU LCEs

\begin{tabular}{|c|c|c|c|c|c|c|c|}
\hline \multicolumn{8}{|c|}{$\begin{array}{c}\text { LEU } \\
{\left[\text { Experimental } k_{e f f}=1.0000 \text { for all except lct26c3 (1.0023)] }\right.}\end{array}$} \\
\hline \multicolumn{4}{|c|}{ MCNP $^{a}$} & \multicolumn{4}{|c|}{ SCALE $^{b}$} \\
\hline $\begin{array}{c}\text { Output } \\
\text { filename }\end{array}$ & $\boldsymbol{k}_{\text {eff }}$ & $\sigma$ & $\begin{array}{c}E A L F \\
(\mathrm{eV})\end{array}$ & Filename $^{c}$ & $\boldsymbol{k}_{\text {eff }}$ & $\sigma$ & $\begin{array}{c}E A L F \\
(\mathrm{eV})\end{array}$ \\
\hline olct1005 & 0.99648 & 0.00028 & $3.88 \mathrm{E}-01$ & lct010c5 & 0.99547 & 0.00049 & $3.87 \mathrm{E}-01$ \\
\hline olct1016 & 0.99561 & 0.00030 & $2.98 \mathrm{E}-01$ & $1 \mathrm{ct} 010 \mathrm{c} 16$ & 0.99354 & 0.00049 & 2.93E-01 \\
\hline olct1017 & 0.99515 & 0.00030 & $2.91 \mathrm{E}-01$ & lct010c17 & 0.99362 & 0.00049 & $2.88 \mathrm{E}-01$ \\
\hline olct1018 & 0.99434 & 0.00031 & $2.86 \mathrm{E}-01$ & lct010c18 & 0.99528 & 0.00049 & $2.83 \mathrm{E}-01$ \\
\hline olct1019 & 0.99445 & 0.00030 & $2.79 \mathrm{E}-01$ & $1 \mathrm{ct} 010 \mathrm{c} 19$ & 0.99210 & 0.00049 & $2.76 \mathrm{E}-01$ \\
\hline olct1703 & 0.99576 & 0.00025 & $9.77 \mathrm{E}-02$ & lct017-03 & 0.99387 & 0.00049 & $5.59 \mathrm{E}-02$ \\
\hline olct1704 & 0.99430 & 0.00024 & $2.17 \mathrm{E}-01$ & lct017-04 & 0.99350 & 0.00047 & $2.14 \mathrm{E}-01$ \\
\hline olct1705 & 0.99618 & 0.00024 & $1.89 \mathrm{E}-01$ & lct017-05 & 0.99460 & 0.00049 & $1.87 \mathrm{E}-01$ \\
\hline olct1706 & 0.99583 & 0.00025 & $1.80 \mathrm{E}-01$ & lct017-06 & 0.99434 & 0.00049 & $1.77 \mathrm{E}-01$ \\
\hline olct1707 & 0.99602 & 0.00024 & $1.69 \mathrm{E}-01$ & lct017-07 & 0.99493 & 0.00050 & $1.67 \mathrm{E}-01$ \\
\hline olct1708 & 0.99347 & 0.00024 & $1.40 \mathrm{E}-01$ & lct17c8 & 0.99184 & 0.00050 & $1.37 \mathrm{E}-01$ \\
\hline olct1709 & 0.99313 & 0.00026 & $1.13 \mathrm{E}-01$ & lct017-09 & 0.99190 & 0.00049 & $1.11 \mathrm{E}-01$ \\
\hline olct1710 & 0.99402 & 0.00024 & $1.03 \mathrm{E}-01$ & lct017-10 & 0.99381 & 0.00050 & $1.01 \mathrm{E}-01$ \\
\hline olct1711 & 0.99454 & 0.00026 & $1.01 \mathrm{E}-01$ & lct017-11 & 0.99392 & 0.00049 & $9.92 \mathrm{E}-02$ \\
\hline olct1712 & 0.99401 & 0.00025 & $9.99 \mathrm{E}-02$ & lct017-12 & 0.99305 & 0.00045 & $9.80 \mathrm{E}-02$ \\
\hline olct1713 & 0.99450 & 0.00025 & $9.85 \mathrm{E}-02$ & lct017-13 & 0.99242 & 0.00048 & $9.65 \mathrm{E}-02$ \\
\hline olct1714 & 0.99415 & 0.00025 & $9.77 \mathrm{E}-02$ & lct017-14 & 0.99271 & 0.00050 & $9.59 \mathrm{E}-02$ \\
\hline olct1715 & 0.99122 & 0.00027 & $1.85 \mathrm{E}-01$ & lct017-15 & 0.99125 & 0.00050 & $1.82 \mathrm{E}-01$ \\
\hline olct1716 & 0.99257 & 0.00028 & $1.78 \mathrm{E}-01$ & lct017-16 & 0.99164 & 0.00049 & $1.75 \mathrm{E}-01$ \\
\hline olct1717 & 0.99422 & 0.00028 & $1.73 \mathrm{E}-01$ & lct17c17 & 0.99401 & 0.00048 & $1.70 \mathrm{E}-01$ \\
\hline olct1719 & 0.99299 & 0.00028 & $1.69 \mathrm{E}-01$ & lct017-19 & 0.99274 & 0.00050 & $1.66 \mathrm{E}-01$ \\
\hline olct1720 & 0.99177 & 0.00027 & $1.68 \mathrm{E}-01$ & lct017-20 & 0.98973 & 0.00049 & $1.64 \mathrm{E}-01$ \\
\hline olct1721 & 0.99132 & 0.00028 & $1.66 \mathrm{E}-01$ & $\operatorname{lct} 017-21$ & 0.98884 & 0.00052 & $1.63 \mathrm{E}-01$ \\
\hline olct1722 & 0.99003 & 0.00026 & $1.65 \mathrm{E}-01$ & lct017-22 & 0.98778 & 0.00048 & $1.62 \mathrm{E}-01$ \\
\hline oclt1723 & 0.99611 & 0.00026 & $1.76 \mathrm{E}-01$ & lct017-23 & 0.99293 & 0.00049 & $1.74 \mathrm{E}-01$ \\
\hline olct1724 & 0.99293 & 0.00026 & $1.71 \mathrm{E}-01$ & lct017-24 & 0.99339 & 0.00049 & $1.69 \mathrm{E}-01$ \\
\hline olct1725 & 0.99303 & 0.00025 & $1.63 \mathrm{E}-01$ & lct017-25 & 0.98962 & 0.0004 & $1.61 \mathrm{E}-01$ \\
\hline olct1728 & 0.99339 & 0.00026 & $3.03 \mathrm{E}-01$ & lct017-28 & 0.99066 & 0.0005 & $3.00 \mathrm{E}-01$ \\
\hline olct1729 & 0.99576 & 0.00025 & $2.69 \mathrm{E}-01$ & lct017-29 & 0.99184 & 0.00049 & $2.65 \mathrm{E}-01$ \\
\hline olct26c3 & 0.99789 & 0.00030 & $1.02 \mathrm{E}+00$ & lct26c3 & 0.99960 & 0.0005 & $9.48 \mathrm{E}-01$ \\
\hline olct $42 \mathrm{c} 1$ & 0.99235 & 0.00028 & $1.76 \mathrm{E}-01$ & lct42c1 & 0.99038 & 0.00049 & $1.73 \mathrm{E}-01$ \\
\hline
\end{tabular}


Table A-3. Criticality calculation results for LEU LCEs (continued)

\begin{tabular}{|c|c|c|c|c|c|c|c|}
\hline \multicolumn{8}{|c|}{$\begin{array}{c}\text { LEU } \\
\text { [Experimental } k_{\text {eff }}=1.0000 \text { for all }\end{array}$} \\
\hline \multicolumn{4}{|c|}{ MCNP $^{a}$} & \multicolumn{4}{|c|}{ SCALE $^{b}$} \\
\hline $\begin{array}{l}\text { Output } \\
\text { filename }\end{array}$ & $\boldsymbol{k}_{\text {eff }}$ & $\sigma$ & $\begin{array}{c}E A L F \\
(\mathrm{eV})\end{array}$ & Filename $^{c}$ & $\boldsymbol{k}_{\text {eff }}$ & $\sigma$ & $\begin{array}{c}E A L F \\
(\mathrm{eV})\end{array}$ \\
\hline olct42c2 & 0.99357 & 0.00028 & $1.82 \mathrm{E}-01$ & $1 \mathrm{ct} 42 \mathrm{c} 2$ & 0.99085 & 0.00047 & $1.80 \mathrm{E}-01$ \\
\hline olct $42 \mathrm{c} 3$ & 0.99372 & 0.00028 & $1.90 \mathrm{E}-01$ & lct42c3 & 0.99304 & 0.00048 & $1.85 \mathrm{E}-01$ \\
\hline olct $42 \mathrm{c} 4$ & 0.99445 & 0.00028 & $1.87 \mathrm{E}-01$ & lct $42 \mathrm{c} 4$ & 0.99277 & 0.00049 & $1.85 \mathrm{E}-01$ \\
\hline olct $42 \mathrm{c} 5$ & 0.99442 & 0.00028 & $1.85 \mathrm{E}-01$ & lct $42 \mathrm{c} 5$ & 0.99320 & 0.00050 & $1.81 \mathrm{E}-01$ \\
\hline olct $42 \mathrm{c} 6$ & 0.99359 & 0.00028 & $1.76 \mathrm{E}-01$ & lct $42 \mathrm{c} 6$ & 0.99190 & 0.00048 & $1.72 \mathrm{E}-01$ \\
\hline olct $42 \mathrm{c} 7$ & 0.99218 & 0.00027 & $1.82 \mathrm{E}-01$ & $1 \mathrm{ct} 42 \mathrm{c} 7$ & 0.99054 & 0.00048 & $1.77 \mathrm{E}-01$ \\
\hline
\end{tabular}

The input and output files are included in the DVD attachment, paths:

${ }^{a} \mathrm{DVD} / \mathrm{exp} / \mathrm{leu} / \mathrm{mcnp}$

${ }^{b}$ DVD/exp/leu/sens.

${ }^{c}$ Output file name is Filename.output. 
Table A-4. MCNP $k_{\text {eff }}$ results for CRCs

\begin{tabular}{|c|c|c|c|c|c|c|}
\hline \multicolumn{7}{|c|}{$\begin{array}{c}\text { Crystal River Unit } 3 \\
\text { Experimental } k_{\text {eff }}=1.0000\end{array}$} \\
\hline \multirow{2}{*}{$\begin{array}{l}\text { State- } \\
\text { point }\end{array}$} & \multicolumn{2}{|c|}{ MCNP4B/ENDF/B-V ${ }^{a}$} & \multicolumn{4}{|c|}{$\begin{array}{l}\text { MCNP 5.1.40/ENDF/B-VI } \\
\end{array}$} \\
\hline & $\boldsymbol{k}_{\text {eff }}$ & $\sigma$ & Output filename $^{b}$ & $\boldsymbol{k}_{\text {eff }}$ & $\sigma$ & $E A L F(\mathrm{eV})$ \\
\hline 1 & 0.99601 & 0.00043 & CR1o & 0.99984 & 0.00028 & $5.79 \mathrm{E}-01$ \\
\hline 2 & 0.99285 & 0.00040 & CR2o & 1.00037 & 0.00030 & $6.52 \mathrm{E}-01$ \\
\hline 3 & 0.99502 & 0.00046 & CR3o & 1.00129 & 0.00029 & $6.38 \mathrm{E}-01$ \\
\hline 4 & 0.99282 & 0.00044 & CR4o & 1.00055 & 0.00028 & $6.75 \mathrm{E}-01$ \\
\hline 5 & 0.99408 & 0.00045 & CR5o & 1.00139 & 0.00028 & $6.78 \mathrm{E}-01$ \\
\hline 6 & 0.99304 & 0.00045 & CR6o & 0.99971 & 0.00027 & $6.72 \mathrm{E}-01$ \\
\hline 7 & 0.99073 & 0.00045 & CR7o & 0.99559 & 0.00027 & $6.70 \mathrm{E}-01$ \\
\hline 8 & 0.99134 & 0.00047 & CR8o & 0.99878 & 0.00027 & $6.86 \mathrm{E}-01$ \\
\hline 9 & 0.99152 & 0.00046 & CR9o & 0.99714 & 0.00028 & $7.02 \mathrm{E}-01$ \\
\hline 10 & 0.99603 & 0.00047 & CR10o & 1.00224 & 0.00028 & $6.90 \mathrm{E}-01$ \\
\hline 11 & 0.99479 & 0.00047 & CR11o & 1.00151 & 0.00028 & $7.46 \mathrm{E}-01$ \\
\hline 12 & 0.99805 & 0.00045 & CR12o & 1.00369 & 0.00027 & $7.36 \mathrm{E}-01$ \\
\hline 13 & 0.99561 & 0.00043 & CR13o & 1.00099 & 0.00028 & $8.13 \mathrm{E}-01$ \\
\hline 14 & 0.99579 & 0.00047 & CR14o & 1.00233 & 0.00021 & $8.17 \mathrm{E}-01$ \\
\hline 15 & 0.99273 & 0.00044 & CR15o & 0.99683 & 0.00028 & 7.60E-01 \\
\hline 16 & 0.99324 & 0.00052 & CR16o & 0.99923 & 0.00029 & 8.99E-01 \\
\hline 17 & 0.99083 & 0.00045 & CR17o & 0.99763 & 0.00028 & $8.68 \mathrm{E}-01$ \\
\hline 18 & 0.99222 & 0.00049 & CR18o & 0.99726 & 0.00029 & $8.74 \mathrm{E}-01$ \\
\hline 19 & 0.98993 & 0.00047 & CR19o & 0.99579 & 0.00030 & $8.59 \mathrm{E}-01$ \\
\hline 20 & 0.99321 & 0.00042 & CR20o & 0.99766 & 0.00029 & $8.04 \mathrm{E}-01$ \\
\hline 21 & 0.99247 & 0.00046 & CR21o & 0.99729 & 0.00028 & $8.05 \mathrm{E}-01$ \\
\hline 22 & 0.99039 & 0.00043 & CR22o & 0.99705 & 0.00029 & $9.59 \mathrm{E}-01$ \\
\hline 23 & 0.99021 & 0.00046 & CR23o & 0.99613 & 0.00030 & $9.68 \mathrm{E}-01$ \\
\hline 24 & 0.99063 & 0.00049 & CR24o & 0.99718 & 0.00029 & $9.53 \mathrm{E}-01$ \\
\hline 25 & 0.99054 & 0.00042 & CR25o & 0.99505 & 0.00029 & $8.80 \mathrm{E}-01$ \\
\hline 26 & 0.99067 & 0.00047 & CR26o & 0.99629 & 0.00030 & $8.70 \mathrm{E}-01$ \\
\hline 27 & 0.98772 & 0.00044 & CR27o & 0.99209 & 0.00031 & 8.49E-01 \\
\hline 28 & 0.99208 & 0.00044 & CR28o & 0.99645 & 0.00029 & $9.85 \mathrm{E}-01$ \\
\hline 29 & 0.99311 & 0.0005 & CR29o & 0.99926 & 0.00028 & $9.58 \mathrm{E}-01$ \\
\hline 30 & 0.99078 & 0.00048 & CR30o & 0.99646 & 0.00029 & $9.46 \mathrm{E}-01$ \\
\hline 31 & 0.98837 & 0.00048 & CR31o & 0.99358 & 0.00029 & $9.08 \mathrm{E}-01$ \\
\hline 32 & 0.99164 & 0.00052 & CR32o & 0.99673 & 0.00029 & $1.04 \mathrm{E}+00$ \\
\hline 33 & 0.98725 & 0.00048 & CR33o & 0.99026 & 0.00031 & $8.89 \mathrm{E}-01$ \\
\hline
\end{tabular}


Table A-4. MCNP $k_{\text {eff }}$ results for CRCs (continued)

\begin{tabular}{|c|c|c|c|c|c|c|}
\hline \multicolumn{7}{|c|}{ Three Mile Island Unit $1\left(\right.$ Experimental $\left.k_{\text {eff }}=\mathbf{1 . 0 0 0 0}\right)$} \\
\hline \multirow{2}{*}{$\begin{array}{l}\text { State- } \\
\text { point }\end{array}$} & \multicolumn{2}{|c|}{ MCNP4B/ENDF/B-V ${ }^{a}$} & \multicolumn{4}{|c|}{ MCNP 5.1.40/ENDF/B-VI } \\
\hline & $\boldsymbol{k}_{\text {eff }}$ & $\sigma$ & Output filename $^{c}$ & $\boldsymbol{k}_{\text {eff }}$ & $\sigma$ & $E A L F(\mathrm{eV})$ \\
\hline 1 & 1.00141 & 0.00042 & TM1o & 1.00525 & 0.00029 & $6.17 \mathrm{E}-01$ \\
\hline 2 & 0.99088 & 0.00046 & TM2o & 0.99859 & 0.00028 & $6.70 \mathrm{E}-01$ \\
\hline 3 & 0.99162 & 0.00048 & TM3o & 0.99697 & 0.00028 & $6.68 \mathrm{E}-01$ \\
\hline \multicolumn{7}{|c|}{ McGuire Unit $1\left(\right.$ Experimental $\left.k_{\text {eff }}=1.0000\right)$} \\
\hline \multirow{2}{*}{$\begin{array}{c}\text { State- } \\
\text { point }\end{array}$} & \multicolumn{2}{|c|}{ MCNP4B/ENDF/B-V ${ }^{a}$} & \multicolumn{4}{|c|}{ MCNP 5.1.40/ENDF/B-VI } \\
\hline & $\boldsymbol{k}_{\text {eff }}$ & $\sigma$ & Output filename $^{d}$ & $\boldsymbol{k}_{\text {eff }}$ & $\sigma$ & $E A L F(e V)$ \\
\hline 1 & 0.99946 & 0.00045 & MG1o & 1.00102 & 0.00029 & $6.37 \mathrm{E}-01$ \\
\hline 2 & 0.98541 & 0.00050 & MG2o & 0.99172 & 0.00030 & $6.91 \mathrm{E}-01$ \\
\hline 3 & 0.98771 & 0.00049 & MG3o & 0.99439 & 0.00028 & $6.92 \mathrm{E}-01$ \\
\hline 4 & 0.98954 & 0.00047 & MG4o & 0.99482 & 0.00029 & $7.42 \mathrm{E}-01$ \\
\hline 5 & 0.99175 & 0.00046 & MG5o & 0.99809 & 0.00028 & $7.26 \mathrm{E}-01$ \\
\hline 6 & 0.98723 & 0.00049 & MG6o & 0.99388 & 0.00029 & $6.92 \mathrm{E}-01$ \\
\hline \multicolumn{7}{|c|}{ Sequoyah Unit $2\left(\right.$ Experimental $\left.k_{\text {eff }}=1.0000\right)$} \\
\hline \multirow{2}{*}{$\begin{array}{c}\text { State- } \\
\text { point }\end{array}$} & \multicolumn{2}{|c|}{ MCNP4B/ENDF/B-V ${ }^{a}$} & \multicolumn{4}{|c|}{ MCNP 5.1.40/ENDF/B-VI } \\
\hline & $\boldsymbol{k}_{\text {eff }}$ & $\sigma$ & Output filename $^{e}$ & $\boldsymbol{k}_{\text {eff }}$ & $\sigma$ & $E A L F(\mathrm{eV})$ \\
\hline 1 & 0.99631 & 0.00043 & SE1o & 0.99977 & 0.00028 & $6.10 \mathrm{E}-01$ \\
\hline 2 & 0.99158 & 0.00044 & SE2o & 0.99694 & 0.00029 & $8.58 \mathrm{E}-01$ \\
\hline 3 & 0.99180 & 0.00050 & SE3o & 0.99698 & 0.00029 & $8.21 \mathrm{E}-01$ \\
\hline \multicolumn{7}{|c|}{ Grand Gulf Unit $1\left(\right.$ Experimental $\left.k_{e f f}=1.0000\right)$} \\
\hline \multirow{2}{*}{$\begin{array}{l}\text { State- } \\
\text { point }\end{array}$} & \multicolumn{2}{|c|}{ MCNP4B/ENDF/B-V ${ }^{a}$} & \multicolumn{4}{|c|}{ MCNP 5.1.40/ENDF/B-VI $f^{f}$} \\
\hline & $\boldsymbol{k}_{\text {eff }}$ & $\sigma$ & Output filename $^{g}$ & $\boldsymbol{k}_{\text {eff }}$ & $\sigma$ & $E A L F(\mathrm{eV})$ \\
\hline 5 & 0.99554 & 0.0001 & oGG5 & 0.99593 & 0.00010 & $2.20 \mathrm{E}-01$ \\
\hline 6 & 0.99324 & 0.0001 & oGG6 & 0.99160 & 0.00010 & $2.69 \mathrm{E}-01$ \\
\hline 7 & 0.99296 & 0.0001 & oGG7 & 0.99125 & 0.00009 & $2.74 \mathrm{E}-01$ \\
\hline 10 & 0.99461 & 0.0001 & oGG10 & 0.99466 & 0.00010 & $2.28 \mathrm{E}-01$ \\
\hline 11 & 0.99810 & 0.0001 & oGG11 & 0.99615 & 0.00010 & $2.80 \mathrm{E}-01$ \\
\hline 12 & 0.98685 & 0.0001 & oGG12 & 0.98679 & 0.00010 & $2.89 \mathrm{E}-01$ \\
\hline 13 & 0.98551 & 0.0001 & oGG13 & 0.98547 & 0.00009 & $2.88 \mathrm{E}-01$ \\
\hline 14 & 0.98295 & 0.0001 & oGG14 & 0.98412 & 0.00009 & $2.83 \mathrm{E}-01$ \\
\hline 15 & 0.98309 & 0.0001 & oGG15 & 0.98163 & 0.00010 & $2.30 \mathrm{E}-01$ \\
\hline 16 & 0.99875 & 0.0001 & oGG16 & 0.99872 & 0.00010 & $2.26 \mathrm{E}-01$ \\
\hline 18 & 0.98993 & 0.0001 & oGG18 & 0.99047 & 0.00010 & $2.26 \mathrm{E}-01$ \\
\hline 19 & 0.98249 & 0.0001 & oGG19 & 0.98031 & 0.00010 & $3.23 \mathrm{E}-01$ \\
\hline 20 & 0.96644 & 0.0001 & oGG20 & 0.96809 & 0.00009 & $3.07 \mathrm{E}-01$ \\
\hline 21 & 0.99211 & 0.0001 & oGG21 & 0.99195 & 0.00010 & $2.29 \mathrm{E}-01$ \\
\hline 22 & 0.99380 & 0.0001 & oGG22 & 0.99146 & 0.00010 & $2.77 \mathrm{E}-01$ \\
\hline 23 & 0.98986 & 0.0001 & oGG23 & 0.98775 & 0.00010 & $2.86 \mathrm{E}-01$ \\
\hline
\end{tabular}

${ }^{a}$ Ref. 61 .

The input and output files are included in the DVD attachment, paths:

${ }^{b} \mathrm{DVD} / \mathrm{exps} / \mathrm{CRC} / \mathrm{CrystalRiver/mcnp}$.

${ }^{c} \mathrm{DVD} / \mathrm{exps} / \mathrm{CRC} / \mathrm{TMI} / \mathrm{mcnp}$.

${ }^{d}$ DVD/exps/CRC/McGuire/monp.

${ }^{e} \mathrm{DVD} / \mathrm{exps} / \mathrm{CRC} /$ Sequoyah/monp.

${ }^{f}$ The results for Grand Gulf Unit 1 were obtained with MCNP jobs from CPILE2.

${ }^{g} \mathrm{DVD} / \mathrm{exps} / \mathrm{CRC} / \mathrm{GrandGulf} / \mathrm{mcnp}$. 
APPENDIX B: Integral Index $c_{k}$

B-1 

This appendix provides the definitions for sensitivity coefficients, $S_{k}$, and integral index $c_{k}$ and the calculated $c_{k}$ values for the application systems and critical experiments (Tables B-1 through B-12). Note that only sensitivity data files (*.sdf) for Crystal River state-points are available among all CRC statepoints. These sensitivity files were obtained with a non-qualified version of SCALE5.1 and the 238-group ENDF/B-V SCALE library and NITAWL for resonance-cross section processing.

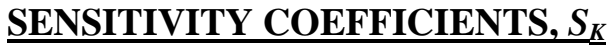

The sensitivity of $k_{\text {eff }}$ to a particular nuclide-reaction pair macroscopic cross section $\sum_{x}^{n}$, referred to as sensitivity coefficient, provides a measure of the first-order effect of perturbations in nuclear reaction $x$ for nuclide $n$ upon $k_{\text {eff. }}$ Nuclear data for which sensitivity coefficients are computed in a TSUNAMI calculation include total, scatter, capture, and fission cross sections, $\bar{v}$ (average number of neutrons per fission event), and $\chi$ (distribution function of fission neutrons). The sensitivity coefficient has been defined in Ref. 63 as

$$
S_{k, \Sigma_{x}^{n}}=\frac{\delta k_{e f f} / k_{e f f}}{\delta \Sigma_{x}^{n} / \Sigma_{x}^{n}} .
$$

A sensitivity coefficient is computed as the sum over all energy groups of the sensitivities of $k_{\text {eff }}$ to group-wise cross-section data. The sensitivity coefficient expressed as a function of energy,

$$
S_{k, \Sigma_{x, j}^{n}}=\frac{\delta k_{e f f} / k_{e f f}}{\delta \Sigma_{x, j}^{n} / \Sigma_{x, j}^{n}},
$$

where $j$ denotes an energy group, is referred to as an energy-dependent sensitivity profile. In addition to an explicit change in the affected nuclide reaction rate, perturbations of $\sum_{x, j}^{n}$ produce secondary effects on the resonance-shielded values of some cross sections, which in turn affect $k_{\text {eff. }}$ Therefore, a complete sensitivity coefficient consists of two components referred to as explicit and implicit sensitivity coefficients. The implicit sensitivity component is the cumulative sensitivity of $k_{\text {eff }}$ to all processes that are influenced by the perturbations in the value of $\sum_{x}^{n}$. TSUNAMI-3D computes sensitivity profiles in a SCALE energy group structure. 


\section{INTEGRAL INDEX $c_{k}$}

The effects of uncertainties in nuclear data on the $k_{\text {eff }}$ values of systems with the same materials and similar spectra are correlated. Integral index $c_{k}$ is a measure of similarity of two systems in terms of their common components of uncertainty in $k_{\text {eff }}$ due to cross-section uncertainties. A $c_{k}$ value represents the correlation coefficient between sensitivity weighted uncertainties in the design system (application) and an experiment. The definition and intended use of the integral index $c_{k}$ are documented in Refs.16 and 63.

Relative uncertainties in cross-section data can be represented as the elements of an $M \times M$ matrix, $C_{\alpha, \alpha} \equiv\left[\frac{\operatorname{cov}\left(\alpha_{n}, \alpha_{m}\right)}{\alpha_{n} \alpha_{m}}\right]$, where $M$ is the product of the number of nuclide-reaction pairs and the number of energy groups and $\alpha \equiv\left(\alpha_{n}\right)$ is a variable array containing the cross-sections of nuclide-reactionenergy group triplets. The $C_{\alpha, \alpha}$ matrix contains covariance data that provide a measure of how strong the correlation of uncertainty is between two nuclide-reaction-energy group triplets. An individual element of the covariance matrix, $c_{n m}$, is the ratio of the covariance of cross-section uncertainties to the product of cross-section expectation values for nuclide-reaction-energy group triplets $n$ and $m$. In a TSUNAMI-IP calculation, the covariance data are propagated to relative changes in the calculated $k_{\text {eff }}$ value of a given system via the sensitivity coefficients. An uncertainty matrix is computed for the system $k_{\text {eff }}$ values, $C_{k k}=S_{k} C_{\alpha, \alpha} S_{k}^{\dagger}$, where $S_{k}$ and $S_{k}^{\dagger}$ are the matrix and the transpose matrix, respectively, containing sensitivities of the calculated $k_{\text {eff }}$ values of critical systems to the $\alpha$ parameters. $S_{k}$ is an $I \times M$ matrix defined as

$$
S_{k} \equiv\left[\frac{\alpha_{m}}{k_{i}} \frac{\partial k_{i}}{\partial \alpha_{m}}\right], \mathrm{i}=1,2, \ldots, I ; m=1,2, \ldots, M,
$$

where $I$ is the number of critical systems being considered.

The diagonal elements of the $C_{k k}$ matrix represent the relative variance values, $\eta_{i}^{2}$, for each of the systems under consideration, and the off-diagonal elements, $\eta_{\mathrm{ij}}^{2}$, represent the common variance between two systems. A correlation coefficient is defined as

$$
c_{k}=\frac{\eta_{i j}^{2}}{\left(\eta_{i} \eta_{j}\right)},
$$

such that the single $c_{k}$ value represents the correlation coefficient between sensitivity weighted uncertainties in system $i$ and system $j$. The interpretation of the correlation coefficient is the following: a value of 0.0 represents no correlation between the systems, a value of 1.0 represents full correlation between the systems, and a value of -1.0 represents a full anticorrelation.

Covariance data for some nuclide-reaction pairs are not available. In the TSUNAMI-IP calculations for this analysis, the default value of 0.05 was used for the fractional standard deviation in cross-section data for nuclide-reaction pairs for which covariance data are not available. This value is deemed to be a conservative estimation for fractional standard deviation in cross-section data in the thermal and ephithermal energy regions and is based on the fractional standard deviation in cross-section data for nuclide-reaction pairs for which covariance data are available. 
Table B-1. Integral index $c_{\mathrm{k}}$ for nominal 21-PWR waste packages and HTC experiments

\begin{tabular}{|c|c|c|c|c|c|c|c|}
\hline $\begin{array}{c}\text { Initial } \\
\text { enrichment } \\
\left(\mathbf{w t} \%{ }^{235} \mathrm{U}\right)\end{array}$ & 2 & 3 & 3 & 3.5 & 4 & 4.5 & 5 \\
\hline $\begin{array}{c}\text { Burnup } \\
\text { (GWd/MTU) }\end{array}$ & 0 & 0 & 15 & 25 & 30 & 35 & 40 \\
\hline Filename $^{a}$ & $\begin{array}{c}t b 2-0 \\
c_{k}\end{array}$ & $\begin{array}{c}\text { tb3-0 } \\
c_{k} \\
\end{array}$ & $\begin{array}{c}\text { tb15 } \\
c_{k} \\
\end{array}$ & $\begin{array}{c}\text { tb25 } \\
c_{k}\end{array}$ & $\begin{array}{c}\text { tb30 } \\
c_{k}\end{array}$ & $\begin{array}{c}\text { tb35 } \\
c_{k}\end{array}$ & $\begin{array}{c}\text { tb40 } \\
c_{k}\end{array}$ \\
\hline htc1c1sen & 0.4595 & 0.4484 & 0.9036 & 0.9094 & 0.9054 & 0.8945 & 0.8972 \\
\hline htc1c2sen & 0.4587 & 0.4478 & 0.9021 & 0.9079 & 0.9039 & 0.8928 & 0.8959 \\
\hline htc1c3sen & 0.4589 & 0.4480 & 0.9017 & 0.9075 & 0.9035 & 0.8923 & 0.8954 \\
\hline htc1c4sen & 0.4709 & 0.4635 & 0.9026 & 0.9089 & 0.9054 & 0.8856 & 0.8998 \\
\hline htc1c5sen & 0.4702 & 0.4628 & 0.9020 & 0.9083 & 0.9047 & 0.8850 & 0.8992 \\
\hline htc1c6sen & 0.4700 & 0.4628 & 0.9008 & 0.9071 & 0.9036 & 0.8837 & 0.8980 \\
\hline htc1c7sen & 0.4803 & 0.4734 & 0.9098 & 0.9160 & 0.9127 & 0.8912 & 0.9080 \\
\hline htc1c8sen & 0.4795 & 0.4727 & 0.9086 & 0.9148 & 0.9116 & 0.8900 & 0.9069 \\
\hline htc1c9sen & 0.4798 & 0.4730 & 0.9079 & 0.9140 & 0.9107 & 0.8890 & 0.9060 \\
\hline htc1c10sen & 0.4951 & 0.4880 & 0.9258 & 0.9317 & 0.9289 & 0.9072 & 0.9249 \\
\hline htc1c11sen & 0.4950 & 0.4879 & 0.9246 & 0.9304 & 0.9275 & 0.9057 & 0.9236 \\
\hline htc1c12sen & 0.4951 & 0.4879 & 0.9257 & 0.9316 & 0.9287 & 0.9071 & 0.9246 \\
\hline htc1c13sen & 0.5177 & 0.5096 & 0.9535 & 0.9588 & 0.9565 & 0.9379 & 0.9531 \\
\hline htc1c14sen & 0.5167 & 0.5085 & 0.9524 & 0.9576 & 0.9553 & 0.9367 & 0.9519 \\
\hline htc1c15sen & 0.5185 & 0.5101 & 0.9527 & 0.9578 & 0.9554 & 0.9367 & 0.9519 \\
\hline htc1c16sen & 0.4809 & 0.4736 & 0.9140 & 0.9201 & 0.9168 & 0.8964 & 0.9118 \\
\hline htc1c17sen & 0.4809 & 0.4736 & 0.9132 & 0.9193 & 0.9159 & 0.8956 & 0.9109 \\
\hline htc1c18sen & 0.4809 & 0.4740 & 0.9106 & 0.9168 & 0.9135 & 0.8921 & 0.9087 \\
\hline htc2c1bsen & 0.5171 & 0.5087 & 0.9575 & 0.9629 & 0.9607 & 0.9435 & 0.9572 \\
\hline htc2c2bsen & 0.5166 & 0.5082 & 0.9578 & 0.9632 & 0.9610 & 0.9439 & 0.9575 \\
\hline htc2c3bsen & 0.5159 & 0.5075 & 0.9617 & 0.9673 & 0.9653 & 0.9494 & 0.9617 \\
\hline htc $2 \mathrm{c} 4 \mathrm{bsen}$ & 0.5148 & 0.5062 & 0.9653 & 0.9710 & 0.9691 & 0.9545 & 0.9654 \\
\hline htc2c5bsen & 0.5144 & 0.5056 & 0.9684 & 0.9743 & 0.9724 & 0.9590 & 0.9685 \\
\hline htc 2 c6bsen & 0.5143 & 0.5055 & 0.9685 & 0.9744 & 0.9725 & 0.9593 & 0.9686 \\
\hline htc2c7bsen & 0.5128 & 0.5040 & 0.9709 & 0.9769 & 0.9751 & 0.9631 & 0.9712 \\
\hline htc2c8bsen & 0.5124 & 0.5033 & 0.9732 & 0.9793 & 0.9775 & 0.9667 & 0.9735 \\
\hline htc2c9bsen & 0.4914 & 0.4824 & 0.9651 & 0.9724 & 0.9701 & 0.9601 & 0.9648 \\
\hline htc2c10bsen & 0.4932 & 0.4843 & 0.9621 & 0.9692 & 0.9668 & 0.9553 & 0.9617 \\
\hline htc2c11bsen & 0.4944 & 0.4859 & 0.9567 & 0.9636 & 0.9611 & 0.9474 & 0.9562 \\
\hline htc2c12bsen & 0.4950 & 0.4869 & 0.9502 & 0.9569 & 0.9543 & 0.9385 & 0.9496 \\
\hline htc2c13bsen & 0.4952 & 0.4875 & 0.9427 & 0.9492 & 0.9465 & 0.9287 & 0.9421 \\
\hline htc2c14bsen & 0.4953 & 0.4879 & 0.9346 & 0.9408 & 0.9380 & 0.9183 & 0.9338 \\
\hline htc2c15bsen & 0.4821 & 0.4745 & 0.9230 & 0.9294 & 0.9262 & 0.9074 & 0.9211 \\
\hline htc2c16bsen & 0.4820 & 0.4740 & 0.9345 & 0.9412 & 0.9382 & 0.9221 & 0.9327 \\
\hline htc2c17bsen & 0.4809 & 0.4723 & 0.9429 & 0.9500 & 0.9470 & 0.9336 & 0.9412 \\
\hline htc2c18bsen & 0.4790 & 0.4698 & 0.9511 & 0.9585 & 0.9557 & 0.9454 & 0.9494 \\
\hline
\end{tabular}


Table B-1. Integral index $c_{\mathrm{k}}$ for nominal 21-PWR waste packages and HTC experiments (continued)

\begin{tabular}{|c|c|c|c|c|c|c|c|}
\hline $\begin{array}{c}\text { Initial } \\
\text { enrichment } \\
\left(w t \%{ }^{235} U\right)\end{array}$ & 2 & 3 & 3 & 3.5 & 4 & 4.5 & 5 \\
\hline $\begin{array}{c}\text { Burnup } \\
(\text { GWd/MTU) }\end{array}$ & 0 & 0 & 15 & 25 & 30 & 35 & 40 \\
\hline Filename $^{a}$ & $\begin{array}{c}\text { tb2-0 } \\
c_{k}\end{array}$ & $\begin{array}{c}\text { tb3-0 } \\
c_{k}\end{array}$ & $\begin{array}{c}\text { tb15 } \\
c_{k}\end{array}$ & $\begin{array}{c}\text { tb25 } \\
c_{k}\end{array}$ & $\begin{array}{c}\text { tb30 } \\
\mathbf{c}_{\mathrm{k}}\end{array}$ & $\begin{array}{c}\text { tb35 } \\
c_{k}\end{array}$ & $\begin{array}{c}\text { tb40 } \\
c_{k}\end{array}$ \\
\hline htc2c19bsen & 0.4821 & 0.4744 & 0.9246 & 0.9310 & 0.9278 & 0.9094 & 0.9226 \\
\hline htc2c20bsen & 0.4714 & 0.4620 & 0.9335 & 0.9404 & 0.9371 & 0.9254 & 0.9302 \\
\hline htc2c21bsen & 0.4720 & 0.4636 & 0.9213 & 0.9279 & 0.9245 & 0.9091 & 0.9182 \\
\hline htc2c1gsen & 0.5158 & 0.5075 & 0.9597 & 0.9653 & 0.9632 & 0.9467 & 0.9597 \\
\hline htc2c2gsen & 0.5155 & 0.5072 & 0.9597 & 0.9652 & 0.9632 & 0.9467 & 0.9596 \\
\hline htc2c3gsen & 0.5139 & 0.5055 & 0.9645 & 0.9704 & 0.9685 & 0.9538 & 0.9649 \\
\hline htc2c4gsen & 0.5137 & 0.5052 & 0.9646 & 0.9706 & 0.9687 & 0.9541 & 0.9651 \\
\hline htc2c5gsen & 0.5131 & 0.5046 & 0.9650 & 0.9710 & 0.9691 & 0.9547 & 0.9654 \\
\hline htc2c6gsen & 0.5107 & 0.5021 & 0.9693 & 0.9756 & 0.9738 & 0.9614 & 0.9701 \\
\hline htc2c7gsen & 0.5106 & 0.5020 & 0.9691 & 0.9754 & 0.9737 & 0.9612 & 0.9699 \\
\hline htc2c8gsen & 0.5082 & 0.4996 & 0.9719 & 0.9785 & 0.9769 & 0.9662 & 0.9731 \\
\hline htc2c9gsen & 0.5086 & 0.5000 & 0.9720 & 0.9785 & 0.9769 & 0.9662 & 0.9731 \\
\hline htc2c10gsen & 0.4869 & 0.4782 & 0.9641 & 0.9718 & 0.9696 & 0.9603 & 0.9645 \\
\hline htc2c11gsen & 0.4901 & 0.4817 & 0.9592 & 0.9666 & 0.9643 & 0.9522 & 0.9594 \\
\hline htc2c12gsen & 0.4895 & 0.4813 & 0.9587 & 0.9662 & 0.9639 & 0.9517 & 0.9591 \\
\hline htc2c13gsen & 0.4928 & 0.4849 & 0.9505 & 0.9575 & 0.9550 & 0.9396 & 0.9504 \\
\hline htc2c14gsen & 0.4928 & 0.4849 & 0.9503 & 0.9573 & 0.9548 & 0.9394 & 0.9502 \\
\hline htc2c15gsen & 0.4945 & 0.4871 & 0.9395 & 0.9459 & 0.9432 & 0.9247 & 0.9390 \\
\hline htc2c16gsen & 0.4942 & 0.4868 & 0.9397 & 0.9462 & 0.9435 & 0.9251 & 0.9393 \\
\hline htc2c17gsen & 0.4801 & 0.4724 & 0.9299 & 0.9368 & 0.9338 & 0.9168 & 0.9285 \\
\hline htc2c18gsen & 0.4715 & 0.4624 & 0.9289 & 0.9358 & 0.9324 & 0.9194 & 0.9258 \\
\hline htc2c19gsen & 0.4784 & 0.4698 & 0.9451 & 0.9525 & 0.9497 & 0.9374 & 0.9439 \\
\hline htc2c20gsen & 0.4808 & 0.4730 & 0.9313 & 0.9381 & 0.9350 & 0.9184 & 0.9297 \\
\hline htc3c1sen & 0.4939 & 0.4847 & 0.9464 & 0.9526 & 0.9495 & 0.9341 & 0.9439 \\
\hline htc3c3sen & 0.4942 & 0.4850 & 0.9480 & 0.9542 & 0.9511 & 0.9361 & 0.9455 \\
\hline htc3c4sen & 0.4949 & 0.4854 & 0.9476 & 0.9536 & 0.9505 & 0.9354 & 0.9448 \\
\hline htc $3 \mathrm{c} 5 \mathrm{sen}$ & 0.4938 & 0.4848 & 0.9488 & 0.9551 & 0.9521 & 0.9371 & 0.9466 \\
\hline htc3c7sen & 0.4942 & 0.4849 & 0.9471 & 0.9532 & 0.9502 & 0.9350 & 0.9446 \\
\hline htc $3 \mathrm{c} 9 \mathrm{sen}$ & 0.4944 & 0.4851 & 0.9480 & 0.9542 & 0.9512 & 0.9362 & 0.9456 \\
\hline htc3c10sen & 0.4945 & 0.4851 & 0.9478 & 0.9540 & 0.9509 & 0.9360 & 0.9453 \\
\hline htc3c11sen & 0.4944 & 0.4855 & 0.9475 & 0.9537 & 0.9508 & 0.9355 & 0.9453 \\
\hline htc3c12sen & 0.4893 & 0.4817 & 0.9227 & 0.9286 & 0.9254 & 0.9049 & 0.9207 \\
\hline htc3c13sen & 0.4903 & 0.4822 & 0.9255 & 0.9314 & 0.9281 & 0.9084 & 0.9232 \\
\hline htc3c14sen & 0.4913 & 0.4827 & 0.9289 & 0.9346 & 0.9313 & 0.9126 & 0.9260 \\
\hline htc3c15sen & 0.4920 & 0.4831 & 0.9300 & 0.9357 & 0.9323 & 0.9139 & 0.9269 \\
\hline htc3c16sen & 0.4915 & 0.4824 & 0.9311 & 0.9368 & 0.9334 & 0.9156 & 0.9279 \\
\hline htc3c17sen & 0.4923 & 0.4827 & 0.9332 & 0.9388 & 0.9354 & 0.9183 & 0.9296 \\
\hline htc3c18sen & 0.4920 & 0.4820 & 0.9335 & 0.9389 & 0.9354 & 0.9189 & 0.9293 \\
\hline
\end{tabular}


Table B-1. Integral index $c_{\mathrm{k}}$ for nominal 21-PWR waste packages and HTC experiments (continued)

\begin{tabular}{|c|c|c|c|c|c|c|c|}
\hline $\begin{array}{c}\text { Initial } \\
\text { enrichment } \\
\left(w t \%^{235} U\right)\end{array}$ & 2 & 3 & 3 & 3.5 & 4 & 4.5 & 5 \\
\hline $\begin{array}{c}\text { Burnup } \\
\text { (GWd/MTU) }\end{array}$ & 0 & 0 & 15 & 25 & 30 & 35 & 40 \\
\hline Filename $^{a}$ & $\begin{array}{c}\text { tb2-0 } \\
c_{k}\end{array}$ & $\begin{array}{c}\text { tb3-0 } \\
c_{k}\end{array}$ & $\begin{array}{c}\text { tb15 } \\
c_{k}\end{array}$ & $\begin{array}{c}\text { tb25 } \\
c_{k}\end{array}$ & $\begin{array}{c}\text { tb30 } \\
c_{k}\end{array}$ & $\begin{array}{c}\text { tb35 } \\
c_{k}\end{array}$ & $\begin{array}{c}\text { tb40 } \\
c_{k}\end{array}$ \\
\hline htc3c19sen & 0.4880 & 0.4783 & 0.9294 & 0.9350 & 0.9314 & 0.9148 & 0.9253 \\
\hline htc3c20sen & 0.4880 & 0.4782 & 0.9294 & 0.9350 & 0.9314 & 0.9150 & 0.9253 \\
\hline htc3c21sen & 0.4839 & 0.4760 & 0.9183 & 0.9243 & 0.9210 & 0.9012 & 0.9158 \\
\hline htc3c22sen & 0.4842 & 0.4770 & 0.9156 & 0.9216 & 0.9184 & 0.8973 & 0.9137 \\
\hline htc3c23sen & 0.4874 & 0.4804 & 0.9178 & 0.9239 & 0.9208 & 0.8992 & 0.9164 \\
\hline htc3c24sen & 0.4940 & 0.4865 & 0.9330 & 0.9391 & 0.9362 & 0.9164 & 0.9316 \\
\hline htc3c $25 \mathrm{sen}$ & 0.4914 & 0.4826 & 0.9329 & 0.9388 & 0.9355 & 0.9176 & 0.9300 \\
\hline htc3c26sen & 0.4913 & 0.4828 & 0.9299 & 0.9357 & 0.9325 & 0.9138 & 0.9273 \\
\hline htc4pb02sen & 0.4953 & 0.4861 & 0.9528 & 0.9591 & 0.9561 & 0.9422 & 0.9505 \\
\hline htc4pb03sen & 0.4947 & 0.4853 & 0.9525 & 0.9588 & 0.9558 & 0.9420 & 0.9501 \\
\hline htc4pb04sen & 0.4945 & 0.4850 & 0.9521 & 0.9584 & 0.9554 & 0.9416 & 0.9496 \\
\hline htc4pb05sen & 0.4944 & 0.4848 & 0.9516 & 0.9578 & 0.9548 & 0.9410 & 0.9490 \\
\hline htc4pb06sen & 0.4948 & 0.4852 & 0.9502 & 0.9563 & 0.9532 & 0.9391 & 0.9474 \\
\hline htc4pb07sen & 0.4947 & 0.4850 & 0.9497 & 0.9558 & 0.9527 & 0.9384 & 0.9469 \\
\hline htc $4 \mathrm{pb} 08$ sen & 0.4943 & 0.4848 & 0.9512 & 0.9574 & 0.9544 & 0.9405 & 0.9487 \\
\hline htc4pb09sen & 0.4938 & 0.4843 & 0.9512 & 0.9574 & 0.9544 & 0.9405 & 0.9487 \\
\hline htc4pb10sen & 0.4946 & 0.4851 & 0.9511 & 0.9572 & 0.9542 & 0.9401 & 0.9484 \\
\hline htc4pb11sen & 0.4945 & 0.4850 & 0.9509 & 0.9571 & 0.9540 & 0.9399 & 0.9483 \\
\hline htc4pb15sen & 0.4948 & 0.4846 & 0.9518 & 0.9579 & 0.9548 & 0.9415 & 0.9489 \\
\hline htc4pb16sen & 0.4952 & 0.4849 & 0.9522 & 0.9582 & 0.9551 & 0.9418 & 0.9492 \\
\hline htc4pb18sen & 0.4941 & 0.4846 & 0.9505 & 0.9567 & 0.9537 & 0.9399 & 0.9480 \\
\hline htc4pb19sen & 0.4940 & 0.4844 & 0.9498 & 0.9560 & 0.9529 & 0.9390 & 0.9472 \\
\hline htc4pb20sen & 0.4942 & 0.4846 & 0.9491 & 0.9552 & 0.9521 & 0.9379 & 0.9463 \\
\hline htc 4 pb21sen & 0.4944 & 0.4847 & 0.9500 & 0.9561 & 0.9531 & 0.9391 & 0.9473 \\
\hline htc 4 pb22sen & 0.4942 & 0.4845 & 0.9498 & 0.9560 & 0.9529 & 0.9388 & 0.9471 \\
\hline htc4pb23sen & 0.4942 & 0.4845 & 0.9499 & 0.9560 & 0.9530 & 0.9389 & 0.9472 \\
\hline htc4pb24sen & 0.4939 & 0.4842 & 0.9492 & 0.9553 & 0.9523 & 0.9380 & 0.9466 \\
\hline htc4pb25sen & 0.4943 & 0.4847 & 0.9486 & 0.9546 & 0.9515 & 0.9372 & 0.9458 \\
\hline htc4pb26sen & 0.4942 & 0.4846 & 0.9482 & 0.9543 & 0.9512 & 0.9368 & 0.9455 \\
\hline htc4pb27sen & 0.4974 & 0.4895 & 0.9408 & 0.9468 & 0.9439 & 0.9257 & 0.9390 \\
\hline htc4pb28sen & 0.4956 & 0.4876 & 0.9394 & 0.9454 & 0.9424 & 0.9245 & 0.9373 \\
\hline htc4pb29sen & 0.4944 & 0.4860 & 0.9393 & 0.9452 & 0.9421 & 0.9248 & 0.9368 \\
\hline htc4pb30sen & 0.4941 & 0.4848 & 0.9413 & 0.9470 & 0.9438 & 0.9279 & 0.9381 \\
\hline htc4pb31sen & 0.4944 & 0.4848 & 0.9407 & 0.9464 & 0.9431 & 0.9273 & 0.9373 \\
\hline htc4pb32sen & 0.4938 & 0.4843 & 0.9393 & 0.9450 & 0.9417 & 0.9255 & 0.9360 \\
\hline htc4pb33sen & 0.4935 & 0.4843 & 0.9373 & 0.9430 & 0.9398 & 0.9230 & 0.9343 \\
\hline htc4pb34sen & 0.4924 & 0.4835 & 0.9354 & 0.9412 & 0.9380 & 0.9207 & 0.9326 \\
\hline htc4pb35sen & 0.4946 & 0.4861 & 0.9392 & 0.9451 & 0.9420 & 0.9247 & 0.9367 \\
\hline
\end{tabular}


Table B-1. Integral index $c_{\mathrm{k}}$ for nominal 21-PWR waste packages and HTC experiments (continued)

\begin{tabular}{|c|c|c|c|c|c|c|c|}
\hline $\begin{array}{c}\text { Initial } \\
\text { enrichment } \\
\left(w t \%{ }^{235} U\right) \\
\end{array}$ & 2 & 3 & 3 & 3.5 & 4 & 4.5 & 5 \\
\hline $\begin{array}{c}\text { Burnup } \\
\text { (GWd/MTU) }\end{array}$ & $\mathbf{0}$ & 0 & 15 & 25 & 30 & 35 & 40 \\
\hline Filename $^{a}$ & $\begin{array}{c}\text { tb2-0 } \\
c_{k}\end{array}$ & $\begin{array}{c}\text { tb3-0 } \\
c_{k}\end{array}$ & $\begin{array}{c}\text { tb15 } \\
c_{k}\end{array}$ & $\begin{array}{c}\text { tb25 } \\
c_{k}\end{array}$ & $\begin{array}{c}\mathbf{t b 3 0} \\
\mathbf{c}_{\mathrm{k}}\end{array}$ & $\begin{array}{c}\text { tb35 } \\
c_{k}\end{array}$ & $\begin{array}{c}\text { tb40 } \\
c_{k}\end{array}$ \\
\hline htc4pb36sen & 0.4938 & 0.4854 & 0.9385 & 0.9445 & 0.9414 & 0.9240 & 0.9362 \\
\hline htc4pb37sen & 0.4939 & 0.4855 & 0.9380 & 0.9440 & 0.9409 & 0.9233 & 0.9356 \\
\hline htc4pb38sen & 0.4937 & 0.4853 & 0.9380 & 0.9440 & 0.9409 & 0.9233 & 0.9356 \\
\hline htc4ss02sen & 0.4972 & 0.4881 & 0.9546 & 0.9608 & 0.9579 & 0.9437 & 0.9522 \\
\hline htc 4 ss03sen & 0.4967 & 0.4875 & 0.9545 & 0.9607 & 0.9578 & 0.9437 & 0.9521 \\
\hline htc4ss04sen & 0.4969 & 0.4875 & 0.9544 & 0.9605 & 0.9575 & 0.9436 & 0.9518 \\
\hline htc4ss05sen & 0.4972 & 0.4877 & 0.9540 & 0.9600 & 0.9570 & 0.9430 & 0.9513 \\
\hline htc4ss06sen & 0.4964 & 0.4869 & 0.9534 & 0.9596 & 0.9566 & 0.9426 & 0.9508 \\
\hline htc4ss07sen & 0.4961 & 0.4866 & 0.9527 & 0.9588 & 0.9558 & 0.9417 & 0.9500 \\
\hline htc4ss08sen & 0.4953 & 0.4858 & 0.9523 & 0.9585 & 0.9555 & 0.9414 & 0.9498 \\
\hline htc 4 ss 09 sen & 0.4950 & 0.4855 & 0.9516 & 0.9578 & 0.9548 & 0.9406 & 0.9491 \\
\hline htc4ss10sen & 0.4972 & 0.4877 & 0.9525 & 0.9585 & 0.9555 & 0.9411 & 0.9497 \\
\hline htc4ss11sen & 0.4965 & 0.4871 & 0.9520 & 0.9581 & 0.9551 & 0.9406 & 0.9493 \\
\hline htc4ss13sen & 0.4968 & 0.4860 & 0.9564 & 0.9623 & 0.9591 & 0.9473 & 0.9529 \\
\hline htc4ss 15 sen & 0.4961 & 0.4868 & 0.9525 & 0.9586 & 0.9556 & 0.9417 & 0.9499 \\
\hline htc4ss 16 sen & 0.4963 & 0.4869 & 0.9515 & 0.9576 & 0.9546 & 0.9403 & 0.9488 \\
\hline htc4ss 17 sen & 0.4949 & 0.4854 & 0.9510 & 0.9572 & 0.9542 & 0.9400 & 0.9485 \\
\hline htc4ss 18 sen & 0.4945 & 0.4849 & 0.9506 & 0.9568 & 0.9538 & 0.9396 & 0.9481 \\
\hline htc4ss19sen & 0.4947 & 0.4850 & 0.9502 & 0.9564 & 0.9534 & 0.9391 & 0.9477 \\
\hline htc4ss20sen & 0.4947 & 0.4851 & 0.9494 & 0.9555 & 0.9525 & 0.9380 & 0.9468 \\
\hline htc4ss21sen & 0.4965 & 0.4870 & 0.9513 & 0.9573 & 0.9542 & 0.9399 & 0.9485 \\
\hline htc4ss22sen & 0.5006 & 0.4928 & 0.9441 & 0.9499 & 0.9470 & 0.9288 & 0.9422 \\
\hline htc4ss23sen & 0.4986 & 0.4907 & 0.9425 & 0.9483 & 0.9454 & 0.9273 & 0.9403 \\
\hline htc4ss24sen & 0.4979 & 0.4897 & 0.9424 & 0.9481 & 0.9451 & 0.9275 & 0.9398 \\
\hline htc 4 ss 25 sen & 0.4974 & 0.4892 & 0.9423 & 0.9481 & 0.9451 & 0.9275 & 0.9398 \\
\hline htc4ss26sen & 0.4970 & 0.4888 & 0.9415 & 0.9474 & 0.9443 & 0.9267 & 0.9390 \\
\hline htc4ss27sen & 0.4969 & 0.4887 & 0.9410 & 0.9468 & 0.9437 & 0.9260 & 0.9384 \\
\hline htc4ss28sen & 0.4963 & 0.4881 & 0.9404 & 0.9463 & 0.9432 & 0.9255 & 0.9379 \\
\hline htc4ss29sen & 0.4983 & 0.4893 & 0.9450 & 0.9507 & 0.9475 & 0.9312 & 0.9417 \\
\hline htc4ss30sen & 0.4992 & 0.4898 & 0.9459 & 0.9514 & 0.9481 & 0.9322 & 0.9422 \\
\hline htc4ss31sen & 0.4995 & 0.4901 & 0.9454 & 0.9509 & 0.9477 & 0.9314 & 0.9419 \\
\hline htc4ss32sen & 0.4964 & 0.4873 & 0.9421 & 0.9478 & 0.9447 & 0.9279 & 0.9391 \\
\hline htc4ss33sen & 0.4963 & 0.4876 & 0.9405 & 0.9463 & 0.9431 & 0.9257 & 0.9377 \\
\hline
\end{tabular}

Note: Cell shading identifies critical experiments applicable to bias and bias uncertainty determination.

${ }^{a}$ TSUNAMI-IP and TSUNAMI-3D input and output files for the applications and the experiments are included in the DVD attachment, paths: DVD/ip, DVD/apps/21 pwr/sens, and DVD/exps/htc/sens, respectively. 
Table B-2. Integral index $c_{k}$ for design-basis 21-PWR waste packages and HTC experiments

\begin{tabular}{|c|c|c|c|c|c|c|c|}
\hline $\begin{array}{c}\begin{array}{c}\text { Initial } \\
\text { enrichment } \\
\left(w t \%{ }^{235} U\right)\end{array} \\
\end{array}$ & 2 & 3 & 3 & 3.5 & 4 & 4.5 & 5 \\
\hline $\begin{array}{c}\text { Burnup } \\
\text { (GWd/MTU) }\end{array}$ & 0 & 0 & 15 & 25 & 30 & 35 & 40 \\
\hline Filename $^{a}$ & $\begin{array}{c}t t 2-0 \\
c_{k}\end{array}$ & $\begin{array}{c}\mathrm{tt} 3-0 \\
\mathbf{c}_{\mathrm{k}}\end{array}$ & $\begin{array}{c}\mathrm{tt15} \\
\mathrm{c}_{\mathrm{k}}\end{array}$ & $\begin{array}{c}\mathrm{tt} 25 \\
\mathrm{c}_{\mathrm{k}}\end{array}$ & $\begin{array}{c}t 30 \\
c_{k}\end{array}$ & $\begin{array}{c}\mathrm{tt} 35 \\
\mathrm{c}_{\mathrm{k}}\end{array}$ & $\begin{array}{c}\mathrm{tt} 40 \\
\mathrm{c}_{\mathrm{k}}\end{array}$ \\
\hline htc1c1sen & 0.4578 & 0.4453 & 0.9017 & 0.9081 & 0.9046 & 0.9011 & 0.8959 \\
\hline htc1c2sen & 0.4570 & 0.4446 & 0.9002 & 0.9067 & 0.9032 & 0.8997 & 0.8945 \\
\hline htc1c3sen & 0.4572 & 0.4447 & 0.8998 & 0.9063 & 0.9027 & 0.8993 & 0.8940 \\
\hline htc1c4sen & 0.4685 & 0.4583 & 0.8982 & 0.9076 & 0.9050 & 0.9018 & 0.8973 \\
\hline htc1c5sen & 0.4678 & 0.4576 & 0.8975 & 0.9070 & 0.9043 & 0.9012 & 0.8966 \\
\hline htc1c6sen & 0.4676 & 0.4575 & 0.8963 & 0.9058 & 0.9032 & 0.9000 & 0.8954 \\
\hline htc1c7sen & 0.4777 & 0.4679 & 0.9049 & 0.9147 & 0.9124 & 0.9094 & 0.9052 \\
\hline htc1c8sen & 0.4769 & 0.4671 & 0.9037 & 0.9135 & 0.9113 & 0.9083 & 0.9041 \\
\hline htc1c9sen & 0.4772 & 0.4674 & 0.9029 & 0.9127 & 0.9104 & 0.9074 & 0.9032 \\
\hline htc1c10sen & 0.4925 & 0.4827 & 0.9210 & 0.9304 & 0.9286 & 0.9258 & 0.9221 \\
\hline htc1c11sen & 0.4923 & 0.4825 & 0.9197 & 0.9291 & 0.9273 & 0.9245 & 0.9207 \\
\hline htc1c12sen & 0.4925 & 0.4826 & 0.9209 & 0.9303 & 0.9284 & 0.9256 & 0.9218 \\
\hline htc1c13sen & 0.5152 & 0.5052 & 0.9497 & 0.9575 & 0.9561 & 0.9538 & 0.9508 \\
\hline htc1c14sen & 0.5141 & 0.5040 & 0.9485 & 0.9563 & 0.9549 & 0.9526 & 0.9495 \\
\hline htc1c15sen & 0.5160 & 0.5057 & 0.9489 & 0.9564 & 0.9550 & 0.9526 & 0.9495 \\
\hline htc1c16sen & 0.4784 & 0.4683 & 0.9094 & 0.9188 & 0.9165 & 0.9135 & 0.9092 \\
\hline htc1c17sen & 0.4784 & 0.4683 & 0.9086 & 0.9180 & 0.9156 & 0.9126 & 0.9082 \\
\hline htc1c18sen & 0.4783 & 0.4685 & 0.9057 & 0.9154 & 0.9131 & 0.9101 & 0.9059 \\
\hline htc2c1bsen & 0.5147 & 0.5046 & 0.9541 & 0.9616 & 0.9602 & 0.9580 & 0.9550 \\
\hline htc2c2bsen & 0.5141 & 0.5040 & 0.9543 & 0.9618 & 0.9605 & 0.9583 & 0.9553 \\
\hline htc2c3bsen & 0.5135 & 0.5036 & 0.9586 & 0.9660 & 0.9647 & 0.9626 & 0.9596 \\
\hline htc2c4bsen & 0.5125 & 0.5025 & 0.9625 & 0.9697 & 0.9684 & 0.9665 & 0.9635 \\
\hline htc2c5bsen & 0.5121 & 0.5022 & 0.9660 & 0.9729 & 0.9717 & 0.9698 & 0.9668 \\
\hline htc 2 c6bsen & 0.5121 & 0.5022 & 0.9661 & 0.9730 & 0.9718 & 0.9699 & 0.9669 \\
\hline htc2c7bsen & 0.5107 & 0.5009 & 0.9688 & 0.9756 & 0.9744 & 0.9726 & 0.9696 \\
\hline htc2c8bsen & 0.5103 & 0.5005 & 0.9714 & 0.9779 & 0.9767 & 0.9750 & 0.9720 \\
\hline htc2c9bsen & 0.4895 & 0.4794 & 0.9635 & 0.9710 & 0.9692 & 0.9672 & 0.9634 \\
\hline htc2c10bsen & 0.4912 & 0.4811 & 0.9601 & 0.9678 & 0.9660 & 0.9639 & 0.9601 \\
\hline htc2c11bsen & 0.4922 & 0.4822 & 0.9541 & 0.9622 & 0.9604 & 0.9582 & 0.9544 \\
\hline htc2c12bsen & 0.4927 & 0.4828 & 0.9469 & 0.9555 & 0.9537 & 0.9513 & 0.9476 \\
\hline htc2c13bsen & 0.4928 & 0.4829 & 0.9389 & 0.9478 & 0.9460 & 0.9436 & 0.9398 \\
\hline htc2c14bsen & 0.4928 & 0.4829 & 0.9303 & 0.9395 & 0.9376 & 0.9350 & 0.9312 \\
\hline htc2c15bsen & 0.4797 & 0.4696 & 0.9189 & 0.9281 & 0.9258 & 0.9229 & 0.9186 \\
\hline htc2c16bsen & 0.4798 & 0.4697 & 0.9311 & 0.9399 & 0.9376 & 0.9349 & 0.9306 \\
\hline htc2c17bsen & 0.4788 & 0.4685 & 0.9403 & 0.9487 & 0.9464 & 0.9438 & 0.9394 \\
\hline htc2c18bsen & 0.4772 & 0.4667 & 0.9494 & 0.9571 & 0.9548 & 0.9524 & 0.9481 \\
\hline
\end{tabular}


Table B-2. Integral index $c_{\mathrm{k}}$ for design-basis 21-PWR waste packages and HTC experiments (continued)

\begin{tabular}{|c|c|c|c|c|c|c|c|}
\hline $\begin{array}{c}\begin{array}{c}\text { Initial } \\
\text { enrichment } \\
\left(w t \%{ }^{235} U\right)\end{array} \\
\end{array}$ & 2 & 3 & 3 & 3.5 & 4 & 4.5 & 5 \\
\hline $\begin{array}{c}\text { Burnup } \\
\text { (GWd/MTU) }\end{array}$ & 0 & 0 & 15 & 25 & 30 & 35 & 40 \\
\hline \multirow{2}{*}{ Filename $^{a}$} & tt2-0 & tt3-0 & tt15 & $\mathrm{tt} 25$ & tt 30 & $\mathrm{tt} 35$ & tt40 \\
\hline & $\mathbf{c}_{\mathrm{k}}$ & $\mathbf{c}_{\mathrm{k}}$ & $\mathbf{c}_{\mathrm{k}}$ & $\mathbf{c}_{\mathrm{k}}$ & $\mathbf{c}_{\mathrm{k}}$ & $\mathbf{c}_{\mathrm{k}}$ & $\mathbf{c}_{\mathrm{k}}$ \\
\hline htc2c19bsen & 0.4797 & 0.4696 & 0.9206 & 0.9297 & 0.9274 & 0.9245 & 0.9202 \\
\hline htc2c20bsen & 0.4695 & 0.4586 & 0.9314 & 0.9391 & 0.9363 & 0.9335 & 0.9287 \\
\hline htc2c21bsen & 0.4699 & 0.4593 & 0.9181 & 0.9266 & 0.9239 & 0.9209 & 0.9162 \\
\hline htc2c1gsen & 0.5134 & 0.5035 & 0.9564 & 0.9640 & 0.9627 & 0.9606 & 0.9575 \\
\hline htc2c2gsen & 0.5131 & 0.5032 & 0.9564 & 0.9639 & 0.9626 & 0.9605 & 0.9575 \\
\hline htc2c3gsen & 0.5116 & 0.5018 & 0.9617 & 0.9690 & 0.9678 & 0.9659 & 0.9629 \\
\hline htc2c4gsen & 0.5114 & 0.5016 & 0.9619 & 0.9692 & 0.9680 & 0.9661 & 0.9631 \\
\hline htc2c5gsen & 0.5108 & 0.5010 & 0.9623 & 0.9696 & 0.9685 & 0.9666 & 0.9636 \\
\hline htc2c6gsen & 0.5085 & 0.4989 & 0.9671 & 0.9742 & 0.9731 & 0.9714 & 0.9684 \\
\hline htc2c7gsen & 0.5084 & 0.4987 & 0.9669 & 0.9741 & 0.9730 & 0.9712 & 0.9683 \\
\hline htc2c8gsen & 0.5061 & 0.4967 & 0.9702 & 0.9771 & 0.9761 & 0.9746 & 0.9717 \\
\hline htc2c9gsen & 0.5065 & 0.4971 & 0.9702 & 0.9772 & 0.9761 & 0.9746 & 0.9717 \\
\hline htc2c10gsen & 0.4850 & 0.4753 & 0.9626 & 0.9704 & 0.9688 & 0.9670 & 0.9633 \\
\hline htc2c11gsen & 0.4881 & 0.4783 & 0.9569 & 0.9652 & 0.9635 & 0.9615 & 0.9578 \\
\hline htc2c12gsen & 0.4875 & 0.4778 & 0.9565 & 0.9648 & 0.9632 & 0.9612 & 0.9574 \\
\hline htc2c13gsen & 0.4905 & 0.4808 & 0.9474 & 0.9561 & 0.9544 & 0.9522 & 0.9484 \\
\hline htc2c14gsen & 0.4905 & 0.4808 & 0.9472 & 0.9559 & 0.9542 & 0.9519 & 0.9482 \\
\hline htc2c15gsen & 0.4921 & 0.4823 & 0.9354 & 0.9446 & 0.9428 & 0.9403 & 0.9366 \\
\hline htc2c16gsen & 0.4918 & 0.4820 & 0.9357 & 0.9449 & 0.9431 & 0.9406 & 0.9369 \\
\hline htc2c17gsen & 0.4778 & 0.4679 & 0.9263 & 0.9355 & 0.9332 & 0.9305 & 0.9263 \\
\hline htc2c18gsen & 0.4695 & 0.4587 & 0.9264 & 0.9345 & 0.9318 & 0.9289 & 0.9242 \\
\hline htc2c19gsen & 0.4764 & 0.4662 & 0.9428 & 0.9512 & 0.9490 & 0.9465 & 0.9422 \\
\hline htc2c20gsen & 0.4785 & 0.4685 & 0.9277 & 0.9368 & 0.9345 & 0.9318 & 0.9275 \\
\hline$h t c 3 c 1 s e n$ & 0.4919 & 0.4808 & 0.9435 & 0.9514 & 0.9490 & 0.9463 & 0.9421 \\
\hline htc $3 \mathrm{c} 3 \mathrm{sen}$ & 0.4923 & 0.4812 & 0.9452 & 0.9530 & 0.9507 & 0.9479 & 0.9437 \\
\hline htc $3 \mathrm{c} 4 \mathrm{sen}$ & 0.4929 & 0.4816 & 0.9448 & 0.9524 & 0.9500 & 0.9472 & 0.9430 \\
\hline htc $3 \mathrm{c} 5 \mathrm{sen}$ & 0.4919 & 0.4810 & 0.9460 & 0.9539 & 0.9516 & 0.9489 & 0.9448 \\
\hline htc3c7sen & 0.4919 & 0.4808 & 0.9440 & 0.9518 & 0.9495 & 0.9468 & 0.9426 \\
\hline htc3c9sen & 0.4921 & 0.4811 & 0.9450 & 0.9528 & 0.9505 & 0.9478 & 0.9437 \\
\hline htc3c10sen & 0.4922 & 0.4810 & 0.9448 & 0.9526 & 0.9503 & 0.9476 & 0.9434 \\
\hline htc3c11sen & 0.4922 & 0.4813 & 0.9444 & 0.9523 & 0.9501 & 0.9474 & 0.9433 \\
\hline htc3c12sen & 0.4867 & 0.4764 & 0.9181 & 0.9273 & 0.9251 & 0.9222 & 0.9181 \\
\hline htc3c13sen & 0.4877 & 0.4771 & 0.9212 & 0.9300 & 0.9277 & 0.9248 & 0.9207 \\
\hline htc3c14sen & 0.4889 & 0.4779 & 0.9249 & 0.9333 & 0.9309 & 0.9279 & 0.9236 \\
\hline htc $3 \mathrm{c} 15 \mathrm{sen}$ & 0.4896 & 0.4784 & 0.9261 & 0.9344 & 0.9319 & 0.9288 & 0.9246 \\
\hline htc3c16sen & 0.4892 & 0.4778 & 0.9274 & 0.9355 & 0.9330 & 0.9300 & 0.9257 \\
\hline htc3c17sen & 0.4899 & 0.4783 & 0.9297 & 0.9375 & 0.9349 & 0.9318 & 0.9275 \\
\hline htc3c18sen & 0.4898 & 0.4777 & 0.9301 & 0.9376 & 0.9349 & 0.9317 & 0.9273 \\
\hline
\end{tabular}


Table B-2. Integral index $c_{\mathrm{k}}$ for design-basis 21-PWR waste packages and HTC experiments (continued)

\begin{tabular}{|c|c|c|c|c|c|c|c|}
\hline $\begin{array}{c}\text { Initial } \\
\text { enrichment } \\
\left(w t \%{ }^{235} U\right)\end{array}$ & 2 & 3 & 3 & 3.5 & 4 & 4.5 & 5 \\
\hline $\begin{array}{c}\text { Burnup } \\
\text { (GWd/MTU) }\end{array}$ & 0 & 0 & 15 & 25 & 30 & 35 & 40 \\
\hline Filename $^{a}$ & $\begin{array}{c}\mathbf{t t 2 - 0} \\
\mathbf{c}_{\mathrm{k}} \\
\end{array}$ & $\begin{array}{c}\mathbf{t t} 3-0 \\
\mathbf{c}_{\mathrm{k}}\end{array}$ & $\begin{array}{c}\text { tt15 } \\
c_{k}\end{array}$ & $\begin{array}{c}\mathrm{tt} 25 \\
\mathbf{c}_{\mathrm{k}} \\
\end{array}$ & $\begin{array}{c}\mathbf{t t 3 0} \\
\mathbf{c}_{\mathrm{k}} \\
\end{array}$ & $\begin{array}{c}\mathrm{tt} 35 \\
\mathbf{c}_{\mathrm{k}}\end{array}$ & $\begin{array}{c}\mathrm{tt} 40 \\
\mathbf{c}_{\mathrm{k}} \\
\end{array}$ \\
\hline htc3c19sen & 0.4858 & 0.4740 & 0.9260 & 0.9337 & 0.9309 & 0.9278 & 0.9233 \\
\hline htc3c20sen & 0.4859 & 0.4739 & 0.9261 & 0.9337 & 0.9309 & 0.9278 & 0.9232 \\
\hline htc3c21sen & 0.4815 & 0.4709 & 0.9140 & 0.9230 & 0.9206 & 0.9176 & 0.9133 \\
\hline htc3c22sen & 0.4817 & 0.4716 & 0.9108 & 0.9203 & 0.9181 & 0.9151 & 0.9110 \\
\hline htc $3 \mathrm{c} 23 \mathrm{sen}$ & 0.4847 & 0.4750 & 0.9129 & 0.9226 & 0.9205 & 0.9176 & 0.9136 \\
\hline htc3c24sen & 0.4916 & 0.4817 & 0.9288 & 0.9379 & 0.9358 & 0.9330 & 0.9291 \\
\hline htc $3 \mathrm{c} 25 \mathrm{sen}$ & 0.4892 & 0.4781 & 0.9292 & 0.9375 & 0.9351 & 0.9321 & 0.9278 \\
\hline htc3c26sen & 0.4889 & 0.4780 & 0.9259 & 0.9344 & 0.9321 & 0.9291 & 0.9249 \\
\hline htc4pb02sen & 0.4934 & 0.4825 & 0.9503 & 0.9578 & 0.9556 & 0.9529 & 0.9488 \\
\hline htc $4 \mathrm{pb} 03$ sen & 0.4928 & 0.4818 & 0.9501 & 0.9576 & 0.9553 & 0.9526 & 0.9485 \\
\hline htc4pb04sen & 0.4926 & 0.4815 & 0.9497 & 0.9572 & 0.9548 & 0.9522 & 0.9480 \\
\hline htc $4 \mathrm{pb} 05 \mathrm{sen}$ & 0.4925 & 0.4813 & 0.9492 & 0.9566 & 0.9543 & 0.9516 & 0.9474 \\
\hline htc4pb06sen & 0.4929 & 0.4816 & 0.9476 & 0.9551 & 0.9527 & 0.9500 & 0.9457 \\
\hline htc4pb07sen & 0.4927 & 0.4814 & 0.9471 & 0.9546 & 0.9522 & 0.9494 & 0.9452 \\
\hline htc $4 \mathrm{pb} 08$ sen & 0.4924 & 0.4812 & 0.9487 & 0.9562 & 0.9539 & 0.9512 & 0.9470 \\
\hline htc4pb09sen & 0.4919 & 0.4807 & 0.9487 & 0.9562 & 0.9539 & 0.9512 & 0.9470 \\
\hline htc4pb10sen & 0.4928 & 0.4815 & 0.9486 & 0.9560 & 0.9537 & 0.9510 & 0.9468 \\
\hline htc4pb11sen & 0.4927 & 0.4814 & 0.9484 & 0.9559 & 0.9535 & 0.9508 & 0.9466 \\
\hline htc4pb15sen & 0.4926 & 0.4809 & 0.9493 & 0.9565 & 0.9541 & 0.9513 & 0.9471 \\
\hline htc4pb16sen & 0.4930 & 0.4812 & 0.9496 & 0.9568 & 0.9544 & 0.9517 & 0.9474 \\
\hline htc4pb18sen & 0.4920 & 0.4809 & 0.9479 & 0.9554 & 0.9531 & 0.9504 & 0.9463 \\
\hline htc4pb19sen & 0.4919 & 0.4807 & 0.9472 & 0.9546 & 0.9523 & 0.9496 & 0.9454 \\
\hline htc4pb20sen & 0.4921 & 0.4808 & 0.9464 & 0.9538 & 0.9515 & 0.9488 & 0.9446 \\
\hline htc4pb21sen & 0.4923 & 0.4810 & 0.9474 & 0.9548 & 0.9524 & 0.9497 & 0.9456 \\
\hline htc4pb22sen & 0.4921 & 0.4807 & 0.9471 & 0.9546 & 0.9523 & 0.9496 & 0.9454 \\
\hline htc4pb23sen & 0.4921 & 0.4807 & 0.9472 & 0.9547 & 0.9524 & 0.9497 & 0.9455 \\
\hline htc4pb24sen & 0.4918 & 0.4804 & 0.9465 & 0.9540 & 0.9517 & 0.9490 & 0.9448 \\
\hline htc4pb25sen & 0.4922 & 0.4808 & 0.9458 & 0.9533 & 0.9510 & 0.9482 & 0.9440 \\
\hline htc4pb26sen & 0.4920 & 0.4807 & 0.9454 & 0.9530 & 0.9506 & 0.9479 & 0.9437 \\
\hline htc4pb27sen & 0.4952 & 0.4850 & 0.9371 & 0.9456 & 0.9435 & 0.9407 & 0.9368 \\
\hline htc4pb28sen & 0.4934 & 0.4831 & 0.9357 & 0.9441 & 0.9419 & 0.9391 & 0.9351 \\
\hline htc4pb29sen & 0.4922 & 0.4816 & 0.9357 & 0.9440 & 0.9417 & 0.9388 & 0.9347 \\
\hline htc4pb30sen & 0.4920 & 0.4807 & 0.9381 & 0.9458 & 0.9433 & 0.9404 & 0.9361 \\
\hline htc4pb31sen & 0.4923 & 0.4807 & 0.9376 & 0.9451 & 0.9426 & 0.9396 & 0.9354 \\
\hline htc4pb32sen & 0.4916 & 0.4801 & 0.9360 & 0.9437 & 0.9412 & 0.9383 & 0.9340 \\
\hline htc4pb33sen & 0.4912 & 0.4799 & 0.9339 & 0.9417 & 0.9393 & 0.9364 & 0.9322 \\
\hline htc4pb34sen & 0.4900 & 0.4790 & 0.9318 & 0.9399 & 0.9375 & 0.9346 & 0.9305 \\
\hline htc4pb35sen & 0.4923 & 0.4817 & 0.9356 & 0.9439 & 0.9415 & 0.9386 & 0.9345 \\
\hline
\end{tabular}


Table B-2. Integral index $c_{\mathrm{k}}$ for design-basis 21-PWR waste packages and HTC experiments (continued)

\begin{tabular}{|c|c|c|c|c|c|c|c|}
\hline $\begin{array}{c}\text { Initial } \\
\text { enrichment } \\
\left(w t \%{ }^{235} U\right)\end{array}$ & 2 & 3 & 3 & 3.5 & 4 & 4.5 & 5 \\
\hline $\begin{array}{c}\text { Burnup } \\
\text { (GWd/MTU) }\end{array}$ & $\mathbf{0}$ & $\mathbf{0}$ & 15 & 25 & 30 & 35 & 40 \\
\hline Filename $^{a}$ & $\begin{array}{c}t \mathrm{tt} 2-0 \\
c_{k}\end{array}$ & $\begin{array}{c}\mathbf{t t 3 - 0} \\
\mathbf{c}_{\mathrm{k}}\end{array}$ & $\begin{array}{c}\mathrm{tt15} \\
\mathrm{c}_{\mathrm{k}}\end{array}$ & $\begin{array}{c}t \mathbf{t} 25 \\
c_{k}\end{array}$ & $\begin{array}{c}\mathbf{t t 3 0} \\
\mathbf{c}_{\mathrm{k}}\end{array}$ & $\begin{array}{c}t \mathbf{t 3 5} \\
\mathbf{c}_{\mathrm{k}}\end{array}$ & $\begin{array}{c}\mathrm{tt} 40 \\
\mathrm{c}_{\mathrm{k}}\end{array}$ \\
\hline htc4pb36sen & 0.4915 & 0.4810 & 0.9349 & 0.9432 & 0.9410 & 0.9381 & 0.9340 \\
\hline htc4pb37sen & 0.4916 & 0.4811 & 0.9344 & 0.9427 & 0.9404 & 0.9375 & 0.9334 \\
\hline htc4pb38sen & 0.4915 & 0.4809 & 0.9344 & 0.9427 & 0.9404 & 0.9375 & 0.9334 \\
\hline htc4ss02sen & 0.4953 & 0.4846 & 0.9521 & 0.9595 & 0.9573 & 0.9546 & 0.9505 \\
\hline htc 4 ss03sen & 0.4949 & 0.4840 & 0.9520 & 0.9594 & 0.9572 & 0.9545 & 0.9504 \\
\hline htc4ss04sen & 0.4951 & 0.4841 & 0.9519 & 0.9593 & 0.9570 & 0.9543 & 0.9502 \\
\hline htc4ss05sen & 0.4953 & 0.4843 & 0.9515 & 0.9588 & 0.9565 & 0.9537 & 0.9496 \\
\hline htc4ss06sen & 0.4945 & 0.4834 & 0.9510 & 0.9583 & 0.9560 & 0.9533 & 0.9491 \\
\hline htc4ss07sen & 0.4943 & 0.4831 & 0.9502 & 0.9576 & 0.9553 & 0.9525 & 0.9484 \\
\hline htc4ss08sen & 0.4935 & 0.4823 & 0.9498 & 0.9573 & 0.9550 & 0.9523 & 0.9481 \\
\hline htc4ss09sen & 0.4931 & 0.4819 & 0.9491 & 0.9566 & 0.9543 & 0.9516 & 0.9474 \\
\hline htc4ss10sen & 0.4953 & 0.4842 & 0.9499 & 0.9573 & 0.9549 & 0.9521 & 0.9480 \\
\hline htc4ss11sen & 0.4946 & 0.4835 & 0.9494 & 0.9569 & 0.9545 & 0.9517 & 0.9476 \\
\hline htc4ss13sen & 0.4947 & 0.4826 & 0.9542 & 0.9608 & 0.9583 & 0.9556 & 0.9513 \\
\hline htc4ss 15 sen & 0.4942 & 0.4832 & 0.9499 & 0.9573 & 0.9550 & 0.9523 & 0.9482 \\
\hline htc4ss16sen & 0.4943 & 0.4832 & 0.9489 & 0.9563 & 0.9539 & 0.9512 & 0.9471 \\
\hline htc4ss 17 sen & 0.4928 & 0.4817 & 0.9483 & 0.9558 & 0.9535 & 0.9508 & 0.9467 \\
\hline htc4ss 18 sen & 0.4924 & 0.4812 & 0.9479 & 0.9554 & 0.9531 & 0.9504 & 0.9463 \\
\hline htc4ss19sen & 0.4925 & 0.4812 & 0.9475 & 0.9550 & 0.9527 & 0.9500 & 0.9458 \\
\hline htc4ss20sen & 0.4925 & 0.4812 & 0.9466 & 0.9542 & 0.9519 & 0.9491 & 0.9450 \\
\hline htc4ss21sen & 0.4945 & 0.4833 & 0.9486 & 0.9560 & 0.9536 & 0.9508 & 0.9467 \\
\hline htc4ss22sen & 0.4984 & 0.4885 & 0.9404 & 0.9487 & 0.9466 & 0.9438 & 0.9400 \\
\hline htc4ss23sen & 0.4965 & 0.4864 & 0.9389 & 0.9471 & 0.9449 & 0.9421 & 0.9381 \\
\hline htc4ss24sen & 0.4958 & 0.4855 & 0.9389 & 0.9469 & 0.9447 & 0.9417 & 0.9377 \\
\hline htc 4 ss 25 sen & 0.4953 & 0.4849 & 0.9388 & 0.9469 & 0.9446 & 0.9417 & 0.9376 \\
\hline htc4ss26sen & 0.4949 & 0.4845 & 0.9380 & 0.9462 & 0.9439 & 0.9409 & 0.9369 \\
\hline htc4ss27sen & 0.4948 & 0.4844 & 0.9374 & 0.9456 & 0.9433 & 0.9403 & 0.9363 \\
\hline htc4ss28sen & 0.4942 & 0.4838 & 0.9368 & 0.9450 & 0.9428 & 0.9398 & 0.9358 \\
\hline htc4ss29sen & 0.4964 & 0.4854 & 0.9420 & 0.9495 & 0.9470 & 0.9440 & 0.9398 \\
\hline htc4ss30sen & 0.4973 & 0.4860 & 0.9429 & 0.9502 & 0.9477 & 0.9446 & 0.9404 \\
\hline htc4ss31sen & 0.4975 & 0.4863 & 0.9424 & 0.9497 & 0.9472 & 0.9442 & 0.9400 \\
\hline htc4ss32sen & 0.4943 & 0.4832 & 0.9388 & 0.9466 & 0.9442 & 0.9412 & 0.9371 \\
\hline htc4ss33sen & 0.4942 & 0.4833 & 0.9370 & 0.9450 & 0.9426 & 0.9397 & 0.9356 \\
\hline
\end{tabular}

Note: Cell shading identifies critical experiments applicable to bias and bias uncertainty determination.

${ }^{a}$ TSUNAMI-IP and TSUNAMI-3D input and output files for the applications and the experiments are included in the DVD attachment, paths: DVD/ip, DVD/apps/21pwr/sens, and DVD/exps/htc/sens, respectively. 
Table B-3. Integral index $c_{k}$ for 44-BWR waste packages and HTC LCEs

\begin{tabular}{|c|c|c|c|c|c|c|c|c|c|c|}
\hline & \multicolumn{5}{|c|}{ Nominal configurations } & \multicolumn{5}{|c|}{ Design-basis configurations } \\
\hline $\begin{array}{c}\text { Initial } \\
\text { enrichment } \\
\left(\text { wt } \%{ }^{235} U\right)\end{array}$ & 3 & 3 & 4 & 4 & 5 & 3 & 3 & 4 & 4 & 5 \\
\hline $\begin{array}{c}\text { Burnup } \\
\text { (GWd/MTU) }\end{array}$ & $\mathbf{0}$ & 10 & $\mathbf{0}$ & 20 & 30 & $\mathbf{0}$ & 10 & $\mathbf{0}$ & 20 & 30 \\
\hline Filename $^{a}$ & $\begin{array}{c}\text { tb3-0 } \\
\mathbf{c}_{\mathrm{k}} \\
\end{array}$ & $\begin{array}{c}\text { tb3-10 } \\
c_{k} \\
\end{array}$ & $\begin{array}{c}\text { tb4-0 } \\
\mathbf{c}_{\mathrm{k}} \\
\end{array}$ & $\begin{array}{c}\text { tb4-20 } \\
c_{k} \\
\end{array}$ & $\begin{array}{c}\text { tb5-30 } \\
c_{k} \\
\end{array}$ & $\begin{array}{c}\text { tt 3-0 } \\
\mathbf{c}_{\mathrm{k}} \\
\end{array}$ & $\begin{array}{c}\mathrm{tt} 3-10 \\
c_{k} \\
\end{array}$ & $\begin{array}{c}\text { tt4-0 } \\
c_{k} \\
\end{array}$ & $\begin{array}{c}\mathrm{tt} 4-20 \\
c_{k}\end{array}$ & $\begin{array}{c}\text { tt5-30 } \\
c_{k}\end{array}$ \\
\hline htc1c1sen & 0.4313 & 0.8846 & 0.4141 & 0.8693 & 0.8596 & 0.4292 & 0.8831 & 0.4124 & 0.8692 & 0.8606 \\
\hline htc1c2sen & 0.4303 & 0.8829 & 0.4131 & 0.8675 & 0.8578 & 0.4281 & 0.8813 & 0.4114 & 0.8674 & 0.8588 \\
\hline htc1c3sen & 0.4304 & 0.8824 & 0.4132 & 0.8670 & 0.8573 & 0.4283 & 0.8809 & 0.4115 & 0.8669 & 0.8583 \\
\hline htc1c4sen & 0.4408 & 0.8773 & 0.4246 & 0.8604 & 0.8504 & 0.4379 & 0.8748 & 0.4220 & 0.8603 & 0.8521 \\
\hline htc1c5sen & 0.4400 & 0.8766 & 0.4238 & 0.8598 & 0.8498 & 0.4371 & 0.8741 & 0.4212 & 0.8597 & 0.8514 \\
\hline htc1c6sen & 0.4398 & 0.8753 & 0.4236 & 0.8584 & 0.8484 & 0.4368 & 0.8727 & 0.4210 & 0.8583 & 0.8500 \\
\hline htc1c7sen & 0.4499 & 0.8831 & 0.4338 & 0.8659 & 0.8560 & 0.4466 & 0.8802 & 0.4308 & 0.8657 & 0.8576 \\
\hline htc1c8sen & 0.4490 & 0.8818 & 0.4330 & 0.8647 & 0.8547 & 0.4457 & 0.8790 & 0.4299 & 0.8645 & 0.8564 \\
\hline htc1c9sen & 0.4492 & 0.8808 & 0.4331 & 0.8635 & 0.8536 & 0.4458 & 0.8779 & 0.4300 & 0.8634 & 0.8553 \\
\hline htc1c10sen & 0.4650 & 0.8990 & 0.4491 & 0.8817 & 0.8721 & 0.4614 & 0.8959 & 0.4456 & 0.8814 & 0.8735 \\
\hline htc1c11sen & 0.4646 & 0.8974 & 0.4486 & 0.8800 & 0.8704 & 0.4609 & 0.8943 & 0.4451 & 0.8797 & 0.8718 \\
\hline htc1c12sen & 0.4647 & 0.8987 & 0.4487 & 0.8814 & 0.8718 & 0.4611 & 0.8956 & 0.4452 & 0.8811 & 0.8732 \\
\hline htc1c13sen & 0.4896 & 0.9290 & 4740 & 0.9124 & 0.9037 & 0.4857 & 0.9259 & 0.4700 & 0.9117 & 0.9042 \\
\hline htc1c14sen & 0.4880 & 0.9276 & 0.4723 & 0.9109 & 0.9022 & 0.4841 & 0.9244 & 0.4684 & 0.9102 & 0.9027 \\
\hline htc1c15sen & 0.4896 & 0.9275 & 0.4738 & 0.9106 & 0.9019 & 0.4856 & 0.9243 & 0.4698 & 0.9099 & 0.9024 \\
\hline htc1c16sen & 0.4506 & 0.8881 & 4343 & 0.8710 & 0.8611 & 0.44 & 0.8853 & 0.43 & 0.8708 & 0.8627 \\
\hline htc1c17sen & 0.4504 & 0.8871 & 0.4341 & 0.8700 & 0.8600 & 0.4471 & 0.8843 & 0.4311 & 0.8698 & 0.8616 \\
\hline htc1c18sen & 0.4504 & 0.8838 & 0.4343 & 0.8666 & 0.8567 & 0.4470 & 0.8809 & 0.4312 & 0.8664 & 0.8582 \\
\hline htc2c1bsen & 0.4892 & 0.9342 & 0.4737 & 0.9179 & 0.9094 & 0.4853 & 0.9310 & 0.4697 & 0.9172 & 0.9098 \\
\hline htc2c2bsen & 0.4888 & 0.9346 & 0.4733 & 0.9184 & 0.9099 & 0.4849 & 0.9315 & 0.4693 & 0.9177 & 0.9103 \\
\hline htc2c3bsen & 0.4890 & 0.9400 & 0.4737 & 0.9243 & 0.9160 & 0.4851 & 0.9370 & 0.4697 & 0.9235 & 0.9162 \\
\hline htc2c4bsen & 0.4886 & 0.9450 & 0.4734 & 0.9298 & 0.9217 & 0.4848 & 0.9420 & 0.4695 & 0.9289 & 0.9217 \\
\hline htc2c5bsen & 0.4889 & 0.9494 & 0.4738 & 0.9346 & 0.9267 & 0.4851 & 0.9465 & 0.4699 & 0.9337 & 0.9266 \\
\hline htc2c6bsen & 0.4888 & 0.9496 & 0.4737 & 0.9348 & 0.9268 & 0.4850 & 0.9467 & 0.4698 & 0.9338 & 0.9267 \\
\hline htc $2 \mathrm{c} 7 \mathrm{bsen}$ & 0.4882 & 0.9534 & 0.4733 & 0.9390 & 0.9313 & 0.4844 & 0.9505 & 0.4694 & 0.9380 & 0.9310 \\
\hline htc2c8bsen & 0.4883 & 0.9568 & 0.4735 & 0.9428 & 0.9352 & 0.4846 & 0.9540 & 0.4697 & 0.9418 & 0.9349 \\
\hline htc2c9bsen & 0.4671 & 0.9505 & 0.4519 & 0.9370 & 0.9288 & 0.4639 & 0.9481 & 0.4487 & 0.9362 & 0.9288 \\
\hline htc2c10bsen & 0.4681 & 0.9458 & 0.4527 & 0.9317 & 0.9233 & 0.4648 & 0.9433 & 0.4494 & 0.9309 & 0.9235 \\
\hline htc2c11bsen & 0.4682 & 0.9382 & 0.4526 & 0.9234 & 0.9148 & 0.4648 & 0.9356 & 0.4493 & 0.9228 & 0.9152 \\
\hline htc2c12bsen & 0.4677 & 0.9295 & 0.4521 & 0.9141 & 0.9052 & 0.4643 & 0.9267 & 0.4487 & 0.9135 & 0.9059 \\
\hline htc2c13bsen & 0.4669 & 0.9199 & 0.4512 & 0.9039 & 0.8948 & 0.4634 & 0.9171 & 0.4478 & 0.9034 & 0.8957 \\
\hline htc2c14bsen & 0.4658 & 0.9097 & 0.4499 & 0.8931 & 0.8837 & 0.4623 & 0.9067 & 0.4465 & 0.8926 & 0.8848 \\
\hline htc2c15bsen & 0.4526 & 0.8988 & 0.4365 & 0.8823 & 0.8726 & 0.4494 & 0.8961 & 0.4336 & 0.8820 & 0.8740 \\
\hline htc2c16bsen & 0.4540 & 0.9132 & 0.4380 & 0.8975 & 0.8881 & 0.4509 & 0.9107 & 0.4351 & 0.8971 & 0.8892 \\
\hline htc2c17bsen & 0.4541 & 0.9244 & 0.4382 & 0.9096 & 0.9005 & 0.4511 & 0.9221 & 0.4354 & 0.9091 & 0.9012 \\
\hline htc2c18bsen & 0.4539 & 0.9360 & 0.4381 & 0.9220 & 0.9133 & 0.4510 & 0.9338 & 0.4354 & 0.9215 & 0.9137 \\
\hline htc2c19bsen & 0.4528 & 0.9008 & 0.4366 & 0.8844 & 0.8747 & 0.4496 & 0.8981 & 0.4337 & 0.8841 & 0.8760 \\
\hline htc2c20bsen & 0.4448 & 0.9161 & 0.4285 & 0.9014 & 0.8921 & 0.4421 & 0.9141 & 0.4262 & 0.9010 & 0.8929 \\
\hline htc2c21bsen & 0.4437 & 0.9002 & 0.4274 & 0.8845 & 0.8748 & 0.4409 & 0.8979 & 0.4249 & 0.8842 & 0.8760 \\
\hline
\end{tabular}


Table B-3. Integral index $c_{k}$ for 44-BWR waste packages and HTC LCEs (continued)

\begin{tabular}{|c|c|c|c|c|c|c|c|c|c|c|}
\hline & \multicolumn{5}{|c|}{ Nominal configurations } & \multicolumn{5}{|c|}{ Design-basis configurations } \\
\hline $\begin{array}{c}\text { Initial } \\
\text { enrichment } \\
\left(w t \%{ }^{235} U\right)\end{array}$ & 3 & 3 & 4 & 4 & 5 & 3 & 3 & 4 & 4 & 5 \\
\hline $\begin{array}{c}\text { Burnup } \\
\text { (GWd/MTU) }\end{array}$ & 0 & 10 & 0 & 20 & 30 & 0 & 10 & $\mathbf{0}$ & 20 & 30 \\
\hline & tb3-0 & tb3-10 & tb4-0 & tb4-20 & tb5-30 & tt3-0 & tt3-10 & tt4-0 & tt4-20 & tt5-30 \\
\hline & $\mathbf{c}_{\mathrm{k}}$ & $\mathbf{c}_{\mathrm{k}}$ & $\mathbf{c}_{\mathrm{k}}$ & $\mathbf{c}_{\mathrm{k}}$ & $\mathbf{c}_{\mathrm{k}}$ & $\mathbf{c}_{\mathrm{k}}$ & $\mathbf{c}_{\mathrm{k}}$ & $\mathbf{c}_{\mathrm{k}}$ & $\mathbf{c}_{\mathrm{k}}$ & $\mathbf{c}_{\mathrm{k}}$ \\
\hline htc2c1gsen & 0.4885 & 0.9373 & 0.4732 & 0.9215 & 0.9131 & 0.4846 & 0.9343 & 0.4692 & 0.9207 & 0.9134 \\
\hline htc2c2gsen & 0.4881 & 0.9373 & 0.4728 & 0.9215 & 0.9131 & 0.4843 & 0.9342 & 0.4688 & 0.9207 & 0.9134 \\
\hline htc2c3gsen & 0.4877 & 0.9442 & 0.4727 & 0.9291 & 0.9210 & 0.4839 & 0.9412 & 0.4688 & 0.9282 & 0.9211 \\
\hline htc2c4gsen & 0.4875 & 0.9445 & 0.4724 & 0.9294 & 0.9213 & 0.4837 & 0.9415 & 0.4685 & 0.9285 & 0.9214 \\
\hline htc2c5gsen & 0.4869 & 0.9451 & 0.4718 & 0.9301 & 0.9220 & 0.4831 & 0.9421 & 0.4679 & 0.9292 & 0.9221 \\
\hline htc2c6gsen & 0.4858 & 0.9517 & 0.4711 & 0.9374 & 0.9298 & 0.4821 & 0.9488 & 0.4672 & 0.9365 & 0.9296 \\
\hline htc2c7gsen & 0.4856 & 0.9515 & 1709 & 372 & 0.9295 & 0.4819 & 9486 & 0.4670 & 0.9363 & 0.9294 \\
\hline htc2c8gsen & 0.4844 & 0.9563 & 0.4700 & 0.9427 & 0.9353 & 0.4807 & 0.9535 & 0.4662 & 0.9417 & 0.9350 \\
\hline htc2c9gsen & 0.4848 & 0.9562 & 0.4704 & 0.9426 & 0.9352 & 0.4811 & 0.9535 & 0.4665 & 0.9416 & 0.9349 \\
\hline htc2c1 & 0.4629 & 0.9504 & & 374 & & 0.45 & 80 & 49 & 9366 & 0.9295 \\
\hline htc2c11gsen & 0.4647 & 0.9426 & 0.4495 & 0.9287 & 0.9203 & 0.4614 & 0.9401 & 0.4463 & 0.9280 & 0.9207 \\
\hline htc2c12gsen & 0.4642 & 0.9422 & 0.4491 & 0.9282 & 0.9199 & 0.4609 & 0.9396 & 0.4459 & 0.9276 & 0.9203 \\
\hline htc2c13gsen & 0.4657 & 0.9305 & 0.4503 & 9154 & 0.9066 & 0.4624 & 0.9277 & 0.4470 & 0.9148 & 0.9073 \\
\hline htc2c14gsen & 0.4657 & 0.9302 & 0.4502 & 0.9151 & 0.9063 & 0.4623 & 0.9274 & 0.4470 & 0.9145 & 0.9070 \\
\hline htc2c15gsen & 0.4659 & 0.9159 & 0.4502 & 0.8998 & 0.8906 & 0.4624 & 0.9130 & 0.4468 & 0.8993 & 0.8916 \\
\hline htc2c16gsen & 0.4656 & 0.9163 & 0.4499 & 0.9002 & 0.8911 & 0.4621 & 0.9134 & 0.4465 & 0.8998 & 0.8921 \\
\hline htc2c17gsen & 0.4517 & 0.9079 & 0.4359 & 0.8922 & 0.8828 & 0.4486 & 0.9054 & 0.4330 & 0.8919 & 0.8839 \\
\hline htc2c18gsen & 0.4439 & 0.9099 & 0.4276 & 0.8949 & 0.8855 & 0.4413 & 0.9079 & 0.4253 & 0.8946 & 0.8865 \\
\hline htc2c19gsen & 0.4521 & 0.9279 & 0.4365 & 0.9136 & 0.9047 & 0.4492 & 0.9256 & 0.4337 & 0.9131 & 0.9054 \\
\hline htc2c20gsen & 0.4524 & 0.9094 & 0.4364 & 0.8937 & 0.8843 & 4493 & 0.9069 & 0.4336 & 0.8934 & 0.8854 \\
\hline htc3c1sen & 0.4659 & 0.9253 & 0.4493 & 0.9092 & 0.8998 & 0.4629 & 0.9228 & 0.4464 & 0.9088 & 0.9007 \\
\hline htc3c3sen & 0.4665 & 0.9273 & 0.4500 & 0.9113 & 0.9020 & 0.4635 & 0.9249 & 0.4471 & 0.9110 & 0.9029 \\
\hline htc3c4sen & 0.4668 & 0.9265 & 0.4501 & 0.9104 & 0.9010 & 0.4638 & 0.9241 & 0.4472 & 0.9100 & 0.9019 \\
\hline htc $3 \mathrm{c} 5 \mathrm{sen}$ & 0.4665 & 0.9284 & 0.4501 & 0.9126 & 0.9033 & 0.4635 & 0.9260 & 0.4473 & 0.9122 & 0.9042 \\
\hline htc3c7sen & 0.4655 & 0.9256 & 0.4489 & 0.9097 & 0.9004 & 0.4623 & 0.9231 & 0.4458 & 0.9092 & 0.9011 \\
\hline htc3c9sen & 0.4660 & 0.9269 & 0.4495 & 0.9111 & 0.9018 & 0.4628 & 0.9244 & 0.4465 & 0.9106 & 0.9026 \\
\hline htc3c10sen & 0.4658 & 0.9266 & 0.4492 & 0.9107 & 0.9014 & 0.4626 & 0.9241 & 0.4462 & 0.9102 & 0.9022 \\
\hline htc3c11sen & 0.4664 & 0.9264 & 0.4500 & 0.9105 & 0.9013 & 0.4632 & 0.9239 & 0.4470 & 0.9101 & 0.9021 \\
\hline htc $3 \mathrm{c} 12 \mathrm{sen}$ & 0.4587 & 0.8964 & 0.4424 & 0.8792 & 0.8694 & 0.4553 & 0.8935 & 0.4392 & 0.8789 & 0.8708 \\
\hline htc3c13sen & 0.4597 & 0.8997 & 0.4432 & 0.8826 & 0.8728 & 0.4563 & 0.8969 & 0.4400 & 0.8823 & 0.8741 \\
\hline htc3c14sen & 0.4608 & 0.9037 & 0.4440 & 0.8866 & 0.8768 & 0.4575 & 0.9010 & 0.4409 & 0.8863 & 0.8781 \\
\hline htc $3 \mathrm{c} 15 \mathrm{sen}$ & 0.4615 & 0.9050 & 0.4446 & 0.8879 & 0.8781 & 0.4582 & 0.9023 & 0.4415 & 0.8876 & 0.8793 \\
\hline htc3c16sen & 0.4611 & 0.9065 & 0.4441 & 0.8896 & 0.8798 & 0.4578 & 0.9039 & 0.4411 & 0.8893 & 0.8810 \\
\hline htc $3 \mathrm{c} 17 \mathrm{sen}$ & 0.4618 & 0.9091 & 0.4447 & 0.8922 & 0.8824 & 0.4586 & 0.9065 & 0.4417 & 0.8919 & 0.8835 \\
\hline htc3c18sen & 0.4615 & 0.9096 & 0.4441 & 0.8927 & 0.8829 & 0.4584 & 0.9072 & 0.4413 & 0.8924 & 0.8840 \\
\hline htc3c19sen & 0.4577 & 0.9057 & 0.4405 & 0.8889 & 0.8791 & 0.4547 & 0.9033 & 0.4378 & 0.8887 & 0.8802 \\
\hline htc3c20sen & 0.4576 & 0.9058 & 0.4404 & 0.8890 & 0.8791 & 0.4546 & 0.9034 & 0.4376 & 0.8887 & 0.8803 \\
\hline$h t c 3 c 21 \operatorname{sen}$ & 0.4535 & 0.8928 & 0.4370 & 0.8758 & 0.8659 & 0.4504 & 0.8901 & 0.4342 & 0.8755 & 0.8673 \\
\hline
\end{tabular}


Table B-3. Integral index $c_{k}$ for 44-BWR waste packages and HTC LCEs (continued)

\begin{tabular}{|c|c|c|c|c|c|c|c|c|c|c|}
\hline & \multicolumn{5}{|c|}{ Nominal configurations } & \multicolumn{5}{|c|}{ Design-basis configurations } \\
\hline $\begin{array}{c}\text { Initial } \\
\text { enrichment } \\
\left(\text { wt } \%{ }^{235} U\right)\end{array}$ & 3 & 3 & 4 & 4 & 5 & 3 & 3 & 4 & 4 & 5 \\
\hline $\begin{array}{c}\text { Burnup } \\
\text { (GWd/MTU) }\end{array}$ & $\mathbf{0}$ & 10 & $\mathbf{0}$ & 20 & 30 & $\mathbf{0}$ & 10 & $\mathbf{0}$ & 20 & 30 \\
\hline Filename $^{a}$ & $\begin{array}{c}\text { tb3-0 } \\
\mathbf{c}_{\mathrm{k}} \\
\end{array}$ & $\begin{array}{c}\text { tb3-10 } \\
c_{k} \\
\end{array}$ & $\begin{array}{c}\text { tb4-0 } \\
\mathbf{c}_{\mathrm{k}} \\
\end{array}$ & $\begin{array}{c}\text { tb4-20 } \\
c_{k} \\
\end{array}$ & $\begin{array}{c}\text { tb5-30 } \\
c_{k} \\
\end{array}$ & $\begin{array}{c}\text { tt 3-0 } \\
c_{k}\end{array}$ & $\begin{array}{c}\mathrm{tt} 3-10 \\
c_{k} \\
\end{array}$ & $\begin{array}{c}\text { tt4-0 } \\
c_{k} \\
\end{array}$ & $\begin{array}{c}\mathrm{tt} 4-20 \\
c_{k}\end{array}$ & $\begin{array}{c}\text { tt5-30 } \\
c_{k}\end{array}$ \\
\hline htc3c22sen & 0.4537 & 0.8891 & 0.4375 & 0.8719 & 0.8621 & 0.4504 & 0.8862 & 0.4345 & 0.8717 & 0.8636 \\
\hline$h t c 3 c 23 \operatorname{sen}$ & 0.4569 & 0.8910 & 0.4408 & 0.8737 & 0.8640 & 0.4534 & 0.8880 & 0.4376 & 0.8735 & 0.8655 \\
\hline htc3c24sen & 0.4660 & 0.9089 & 0.4500 & 0.8920 & 0.8824 & 0.4629 & 0.9062 & 0.4470 & 0.8917 & 0.8837 \\
\hline htc3c25sen & 0.4624 & 0.9093 & 0.4456 & 0.8924 & 0.8827 & 0.4593 & 0.9067 & 0.4428 & 0.8922 & 0.8839 \\
\hline htc $3 \mathrm{c} 26 \mathrm{sen}$ & 0.4611 & 0.9050 & 0.4444 & 0.8880 & 0.8783 & 0.4578 & 0.9023 & 0.4413 & 0.8878 & 0.8795 \\
\hline htc4pb02sen & 0.4687 & 0.9335 & 0.4524 & 0.9178 & 0.9087 & 0.4658 & 0.9311 & 4496 & 0.9174 & 0.9095 \\
\hline htc $4 \mathrm{pb} 03$ sen & 0.4679 & 0.9333 & 0.4515 & 0.9177 & 0.9085 & 0.4650 & 0.9309 & 0.4488 & 0.9173 & 0.9093 \\
\hline htc4pb04sen & 0.4675 & 0.9328 & 0.4510 & 0.9171 & 0.9079 & 0.4646 & 0.9304 & 0.4483 & 0.9168 & 0.9087 \\
\hline htc4pb05sen & 0.4672 & 0.9321 & 0.4506 & 0.9164 & 0.9072 & 0.4643 & 0.9298 & 0.4478 & 0.9161 & 0.9080 \\
\hline htc4pb06sen & 0.4672 & 0.9301 & 0.4505 & 0.9142 & 0.9049 & 0.4642 & 0.9277 & 0.4477 & 0.9139 & 0.9057 \\
\hline htc $4 \mathrm{pb} 07$ sen & 0.4669 & 0.9294 & 0.4501 & 0.9135 & 0.9042 & 0.4639 & 0.9271 & 0.4473 & 0.9132 & 0.9050 \\
\hline htc4pb08sen & 0.4671 & 0.9316 & 0.4506 & 0.9159 & 0.9067 & 0.4642 & 0.9293 & 0.4478 & 0.9155 & 0.9075 \\
\hline htc4pb09sen & 0.4667 & 0.9316 & 0.4501 & 0.9160 & 0.9068 & 0.4637 & 0.9293 & 0.4473 & 0.9156 & 0.9076 \\
\hline htc4pb10sen & 0.4673 & 0.9313 & 0.4507 & 0.9155 & 0.9062 & 0.4644 & 0.9289 & 0.4479 & 0.9151 & 0.9070 \\
\hline htc4pb11sen & 0.4672 & 0.9311 & 0.4506 & 0.9153 & 0.9060 & 0.4643 & 0.9288 & 0.4478 & 0.9149 & 0.9068 \\
\hline htc4pb15sen & 0.4665 & 0.9318 & 496 & 0.9162 & 0.90 & 0.46 & 0.9293 & 0.4464 & 0.9156 & 0.9075 \\
\hline htc4pb16sen & 0.4668 & 0.9322 & 0.4500 & 0.9166 & 0.9074 & 0.4635 & 0.9297 & 0.4468 & 0.9160 & 0.9079 \\
\hline htc4pb18sen & 0.4666 & 0.9307 & 0.4502 & 0.9152 & 0.9060 & 0.4635 & 0.9283 & 0.4473 & 0.9147 & 0.9067 \\
\hline htc4pb19sen & 0.466 & 0.9296 & 4494 & 0.9139 & 0.90 & 0.46 & 0.9272 & 0.4464 & 0.9135 & 0.9054 \\
\hline htc4pb20sen & 0.4659 & 0.9285 & 0.4493 & 0.9128 & 0.9035 & 0.4628 & 0.9261 & 0.4463 & 0.9123 & 0.9042 \\
\hline htc4pb21sen & 0.4663 & 0.9297 & 0.4497 & 0.9140 & 0.9048 & 0.4632 & 0.9273 & 0.4467 & 0.9135 & 0.9055 \\
\hline htc4pb22sen & 0.4660 & 0.9295 & 0.4493 & 0.9137 & 0.9045 & 0.4628 & 0.9270 & 0.4463 & 0.9133 & 0.9052 \\
\hline htc4pb23sen & 0.4660 & 0.9295 & 0.4493 & 0.9138 & 0.9046 & 0.4628 & 0.9271 & 0.4463 & 0.9133 & 0.9053 \\
\hline htc4pb24sen & 0.4656 & 0.9287 & 0.4489 & 0.9129 & 0.9037 & 0.4624 & 0.9262 & 0.4459 & 0.9125 & 0.9044 \\
\hline htc4pb25sen & 0.4658 & 0.9278 & 0.4491 & 0.9120 & 0.9027 & 0.4626 & 0.9253 & 0.4461 & 0.9115 & 0.9034 \\
\hline htc4pb26sen & 0.4656 & 0.9273 & 0.4489 & 0.9115 & 0.9022 & 0.4624 & 0.9248 & 0.4458 & 0.9110 & 0.9029 \\
\hline htc4pb27sen & 0.4703 & 0.9181 & 0.4542 & 0.9014 & 0.8919 & 0.4671 & 0.9154 & 0.4512 & 0.9011 & 0.8931 \\
\hline htc4pb28sen & 0.4683 & 0.9167 & 0.4520 & 0.9001 & 0.8906 & 0.4652 & 0.9141 & 0.4492 & 0.8998 & 0.8918 \\
\hline htc4pb29sen & 0.4669 & 0.9169 & 0.4505 & 0.9003 & 0.8908 & 0.4638 & 0.9143 & 0.4477 & 0.9000 & 0.8919 \\
\hline htc4pb30sen & 0.4659 & 0.9193 & 0.4492 & 0.9029 & 0.8934 & 0.4629 & 0.9169 & 0.4464 & 0.9026 & 0.8944 \\
\hline htc4pb31sen & 0.4655 & 0.9184 & 0.4485 & 0.9019 & 0.8923 & 0.4624 & 0.9159 & 0.4457 & 0.9016 & 0.8933 \\
\hline htc4pb32sen & 0.4644 & 0.9165 & 0.4475 & 0.8999 & 0.8904 & 0.4613 & 0.9140 & 0.4445 & 0.8996 & 0.8914 \\
\hline htc4pb33sen & 0.4639 & 0.9140 & 0.4471 & 0.8973 & 0.8877 & 0.4606 & 0.9114 & 0.4440 & 0.8970 & 0.8887 \\
\hline htc4pb34sen & 0.4627 & 0.9118 & 0.4460 & 0.8951 & 0.8855 & 0.4594 & 0.9091 & 0.4429 & 0.8948 & 0.8866 \\
\hline htc4pb35sen & 0.4669 & 0.9167 & 0.4505 & 0.9001 & 0.8905 & 0.4639 & 0.9142 & 0.4477 & 0.8998 & 0.8917 \\
\hline htc4pb36sen & 0.4662 & 0.9161 & 0.4498 & 0.8995 & 0.8900 & 0.4631 & 0.9135 & 0.4470 & 0.8992 & 0.8911 \\
\hline htc4pb37sen & 0.4662 & 0.9154 & 0.4498 & 0.8987 & 0.8892 & 0.4631 & 0.9128 & 0.4470 & 0.8985 & 0.8904 \\
\hline htc4pb38sen & 0.4659 & 0.9154 & 0.4495 & 0.8987 & 0.8892 & 0.4629 & 0.9128 & 0.4467 & 0.8985 & 0.8904 \\
\hline
\end{tabular}


Table B-3. Integral index $c_{k}$ for 44-BWR waste packages and HTC LCEs (continued)

\begin{tabular}{|c|c|c|c|c|c|c|c|c|c|c|}
\hline & \multicolumn{5}{|c|}{ Nominal configurations } & \multicolumn{5}{|c|}{ Design-basis configurations } \\
\hline $\begin{array}{c}\text { Initial } \\
\text { enrichment } \\
\left(w t \%{ }^{235} U\right)\end{array}$ & 3 & 3 & 4 & 4 & 5 & 3 & 3 & 4 & 4 & 5 \\
\hline $\begin{array}{c}\text { Burnup } \\
(\text { GWd/MTU) }\end{array}$ & $\mathbf{0}$ & 10 & 0 & 20 & 30 & 0 & 10 & $\mathbf{0}$ & 20 & 30 \\
\hline Filen an & tb3-0 & tb3-10 & tb4-0 & tb4-20 & tb5-30 & tt3-0 & tt3-10 & tt4-0 & tt4-20 & tt5-30 \\
\hline & $c_{k}$ & $\mathbf{c}_{\mathrm{k}}$ & $\mathbf{c}_{\mathrm{k}}$ & $\mathbf{c}_{\mathrm{k}}$ & $c_{k}$ & $\mathbf{c}_{\mathrm{k}}$ & $\mathbf{c}_{\mathrm{k}}$ & $\mathbf{c}_{\mathrm{k}}$ & $c_{k}$ & $c_{k}$ \\
\hline htc4ss02sen & 0.4716 & 0.9355 & 0.4553 & 0.9198 & 0.9106 & 0.4688 & 0.9333 & 0.4527 & 0.9195 & 0.9115 \\
\hline htc 4 ss 03 sen & 0.4710 & 0.9355 & 0.4547 & 0.9198 & 0.9106 & 0.4682 & 0.9333 & 0.4521 & 0.9194 & 0.9114 \\
\hline htc4ss04sen & 0.4709 & 0.9353 & 0.4545 & 0.9195 & 0.9103 & 0.4682 & 0.9331 & 0.4519 & 0.9192 & 0.9111 \\
\hline htc 4 ss 05 sen & 0.4710 & 0.9347 & 0.4545 & 0.9188 & 0.9095 & 0.4683 & 0.9325 & 0.4520 & 0.9185 & 0.9104 \\
\hline htc4ss06sen & 0.4699 & 0.9341 & 0.4533 & 0.9182 & 0.9090 & 0.4671 & 0.9319 & 0.4507 & 0.9179 & 0.9098 \\
\hline htc4ss07sen & 0.4694 & 0.9331 & 0.4528 & 0.9173 & 0.9080 & 0.4666 & 0.9309 & 0.4502 & 0.9169 & 0.9088 \\
\hline htc 4 ss 08 sen & 0.4685 & 0.9328 & 0.4520 & 0.9170 & 0.90 & 4657 & 0.9305 & 0.4493 & 0.9167 & 0.9086 \\
\hline htc4ss09sen & 0.4680 & 0.9319 & 0.4514 & 0.9161 & 0.9069 & 0.4651 & 0.9296 & 0.4487 & 0.9158 & 0.9077 \\
\hline htc4ss10sen & 0.4707 & 0.9327 & 0.4541 & 0.9167 & 0.9074 & 0.4679 & 0.9305 & 0.4515 & 0.9164 & 0.9083 \\
\hline htc 4 ss 11 sen & 0.4699 & 0.9323 & 4533 & 0.9163 & 0.90 & 0.46 & 0.9301 & 0.4507 & 0.9160 & 0.9079 \\
\hline htc4ss 13 sen & 0.4689 & 0.9374 & 0.4518 & 0.9219 & 0.9128 & 0.4656 & 0.9350 & 0.4487 & 0.9213 & 0.9131 \\
\hline htc 4 ss $15 \mathrm{sen}$ & 0.4697 & 0.9331 & 0.4533 & 0.9174 & 0.9082 & 0.4668 & 0.9307 & 0.4505 & 0.9169 & 0.9089 \\
\hline htc4ss16sen & 0.4693 & 0.9315 & 0.4527 & 0.9156 & 0.9064 & 0.4663 & 0.9292 & 0.4499 & 0.9152 & 0.9072 \\
\hline htc 4 ss 17 sen & 0.4675 & 0.9310 & 0.4510 & 0.9153 & 0.9061 & 0.4644 & 0.9286 & 0.4481 & 0.9148 & 0.9068 \\
\hline htc4ss 18 sen & 0.4668 & 0.9305 & 0.4502 & 0.9148 & 0.9056 & 0.4636 & 0.9280 & 0.4472 & 0.9143 & 0.9063 \\
\hline htc4ss 19sen & 0.4667 & 0.9299 & 0.4500 & 0.9141 & 0.9049 & 0.4635 & 0.9274 & 0.4470 & 0.9137 & 0.9056 \\
\hline htc4ss20sen & 0.4665 & 0.9288 & 0.4498 & 0.9129 & 0.9037 & 0.4633 & 0.9263 & 0.4468 & 0.9125 & 0.9044 \\
\hline htc 4 ss 21 sen & 0.4692 & 0.9310 & 0.4526 & 0.9151 & 0.9058 & 0.4662 & 0.9287 & 0.4498 & 0.9147 & 0.9066 \\
\hline htc4ss 22 sen & 0.4747 & 0.9218 & 0.4587 & 0.9049 & 0.8955 & 0.4719 & 0.9193 & 0.4561 & 0.9047 & 0.8968 \\
\hline htc 4 ss 23 sen & 0.4726 & 0.9203 & 0.4565 & 0.9034 & 0.8939 & 0.4699 & 0.9179 & 0.4540 & 0.9033 & 0.8953 \\
\hline htc 4 ss 24 sen & 0.4718 & 0.9204 & 0.4555 & 0.9035 & 0.8940 & 0.4691 & 0.9181 & 0.4531 & 0.9034 & 0.8953 \\
\hline htc 4 ss $25 \mathrm{sen}$ & 0.4713 & 0.9204 & 0.4550 & 0.9036 & 0.8940 & 0.4686 & 0.9181 & 0.4526 & 0.9035 & 0.8953 \\
\hline htc 4 ss 26 sen & 0.4707 & 0.9195 & 0.4544 & 0.9027 & 0.8931 & 0.4680 & 0.9171 & 0.4519 & 0.9025 & 0.8944 \\
\hline htc4ss27sen & 0.4704 & 0.9187 & 0.4540 & 0.9018 & 0.8923 & 0.4676 & 0.9163 & 0.4515 & 0.9017 & 0.8936 \\
\hline htc 4 ss 28 sen & 0.4697 & 0.9181 & 0.4534 & 0.9013 & 0.8917 & 0.4669 & 0.9157 & 0.4508 & 0.9011 & 0.8930 \\
\hline htc 4 ss 29 sen & 0.4720 & 0.9237 & 0.4553 & 0.9069 & 0.8974 & 0.4695 & 0.9216 & 0.4530 & 0.9069 & 0.8986 \\
\hline htc4ss30sen & 0.4724 & 0.9244 & 0.4556 & 0.9076 & 0.8979 & 0.4700 & 0.9224 & 0.4533 & 0.9075 & 0.8992 \\
\hline htc4ss31sen & 0.4724 & 0.9236 & 0.4556 & 0.9066 & 0.8970 & 0.4699 & 0.9215 & 0.4533 & 0.9066 & 0.8983 \\
\hline htc 4 ss 32 sen & 0.4684 & 0.9197 & 0.4517 & 0.9029 & 0.8933 & 0.4655 & 0.9173 & 0.4490 & 0.9027 & 0.8944 \\
\hline htc 4 ss 33 sen & 0.4681 & 0.9175 & 0.4515 & 0.9007 & 0.8910 & 0.4652 & 0.9151 & 0.4488 & 0.9005 & 0.8922 \\
\hline
\end{tabular}

Note: Cell shading identifies critical experiments applicable to bias and bias uncertainty determination.

${ }^{a}$ TSUNAMI-IP and TSUNAMI-3D input and output files for the applications and the experiments are included in the DVD attachment, paths: DVD/ip, DVD/apps/44bwr/sens, and DVD/exps/htc/sens, respectively. 
Table B-4. Integral index $c_{k}$ for nominal 21-PWR waste packages and MOX LCEs

\begin{tabular}{|c|c|c|c|c|c|c|c|}
\hline $\begin{array}{c}\begin{array}{c}\text { Initial } \\
\text { enrichment } \\
\left(w t \%{ }^{235} U\right)\end{array} \\
\end{array}$ & 2 & 3 & 3 & 3.5 & 4 & 4.5 & 5 \\
\hline $\begin{array}{c}\text { Burnup } \\
\text { (GWd/MTU) }\end{array}$ & $\mathbf{0}$ & $\mathbf{0}$ & 15 & 25 & 30 & 35 & 40 \\
\hline Filename $^{a}$ & $\begin{array}{c}\text { tb2-0 } \\
c_{k}\end{array}$ & $\begin{array}{c}\text { tb3-0 } \\
c_{k}\end{array}$ & $\begin{array}{c}\text { tb15 } \\
c_{k}\end{array}$ & $\begin{array}{c}\text { tb25 } \\
c_{k} \\
\end{array}$ & $\begin{array}{c}\text { tb30 } \\
c_{k} \\
\end{array}$ & $\begin{array}{c}\text { tb35 } \\
c_{k}\end{array}$ & $\begin{array}{c}\text { tb40 } \\
c_{k}\end{array}$ \\
\hline mct002-01sen & 0.2426 & 0.2323 & 0.8926 & 0.9217 & 0.9232 & 0.9337 & 0.9233 \\
\hline mct002-02sen & 0.2394 & 0.2294 & 0.8994 & 0.9291 & 0.9309 & 0.9455 & 0.9311 \\
\hline mct002-03sen & 0.2072 & 0.1979 & 0.8474 & 0.8769 & 0.8773 & 0.8833 & 0.8764 \\
\hline mct002-04sen & 0.1962 & 0.1871 & 0.8821 & 0.9141 & 0.9151 & 0.9329 & 0.9134 \\
\hline mct002-05sen & 0.1939 & 0.1849 & 0.8315 & 0.8612 & 0.8612 & 0.8673 & 0.8596 \\
\hline met002-06sen & 0.1838 & 0.1747 & 0.8695 & 0.9015 & 0.9019 & 0.9201 & 0.8991 \\
\hline met003-01sen & 0.1277 & 0.1240 & 0.8141 & 0.8529 & 0.8578 & 0.8748 & 0.8635 \\
\hline mct003-02sen & 0.1189 & 0.1156 & 0.7985 & 0.8370 & 0.8413 & 0.8552 & 0.8468 \\
\hline mct003-03sen & 0.1195 & 0.1162 & 0.8062 & 0.8452 & 0.8499 & 0.8654 & 0.8555 \\
\hline mct003-04sen & 0.0958 & 0.0931 & 0.7549 & 0.7921 & 0.7952 & 0.8050 & 0.7989 \\
\hline mct003-05sen & 0.0919 & 0.0892 & 0.7484 & 0.7854 & 0.7882 & 0.7979 & 0.7914 \\
\hline mct003-06sen & 0.0826 & 0.0798 & 0.7437 & 0.7805 & 0.7825 & 0.7943 & 0.7840 \\
\hline mct004-01sen & 0.1852 & 0.1773 & 0.8328 & 0.8658 & 0.8672 & 0.8764 & 0.8678 \\
\hline mct006-01sen & 0.2301 & 0.2202 & 0.8779 & 0.9073 & 0.9084 & 0.9166 & 0.9084 \\
\hline mct007-02sen & 0.2131 & 0.2030 & 0.8492 & 0.8783 & 0.8781 & 0.8850 & 0.8760 \\
\hline met008-01sen & 0.2664 & 0.2540 & 0.9049 & 0.9329 & 0.9336 & 0.9446 & 0.9324 \\
\hline mct008-02sen & 0.2433 & 0.2318 & 0.8769 & 0.9054 & 0.9055 & 0.9133 & 0.9036 \\
\hline mct008-03sen & 0.2304 & 0.2191 & 0.8622 & 0.8908 & 0.8905 & 0.8983 & 0.8880 \\
\hline met008-04sen & 0.2229 & 0.2117 & 0.8556 & 0.8842 & 0.8837 & 0.8924 & 0.8806 \\
\hline met008-05sen & 0.2131 & 0.2013 & 0.8532 & 0.8820 & 0.8810 & 0.8936 & 0.8766 \\
\hline mct008-06sen & 0.2099 & 0.1978 & 0.8525 & 0.8813 & 0.8802 & 0.8945 & 0.8752 \\
\hline mst001-01sen & 0.0533 & 0.0516 & 0.7426 & 0.7838 & 0.7887 & 0.8055 & 0.7951 \\
\hline mst001-02sen & 0.0534 & 0.0554 & 0.7446 & 0.7858 & 0.7908 & 0.8078 & 0.7972 \\
\hline mst001-03sen & 0.0568 & 0.0518 & 0.7327 & 0.7731 & 0.7780 & 0.7924 & 0.7846 \\
\hline mst001-04sen & 0.0535 & 0.0512 & 0.7450 & 0.7864 & 0.7915 & 0.8085 & 0.7981 \\
\hline mst001-05sen & 0.0530 & 0.0571 & 0.7536 & 0.7954 & 0.8005 & 0.8192 & 0.8069 \\
\hline mst001-06sen & 0.0585 & 0.0193 & 0.7271 & 0.7674 & 0.7725 & 0.7853 & 0.7796 \\
\hline mst001-08sen & 0.0187 & 0.0209 & 0.6997 & 0.7424 & 0.7482 & 0.7644 & 0.7562 \\
\hline mst001-09sen & 0.0199 & 0.0502 & 0.7040 & 0.7458 & 0.7505 & 0.7665 & 0.7563 \\
\hline mst001-10sen & 0.0519 & 0.0514 & 0.7446 & 0.7854 & 0.7897 & 0.8065 & 0.7947 \\
\hline mst001-11sen & 0.0533 & 0.0484 & 0.7460 & 0.7867 & 0.7908 & 0.8073 & 0.7957 \\
\hline mst001-12sen & 0.0503 & 0.0499 & 0.7396 & 0.7801 & 0.7842 & 0.8009 & 0.7891 \\
\hline mst001-13sen & 0.0517 & 0.0314 & 0.7459 & 0.7861 & 0.7896 & 0.8067 & 0.7930 \\
\hline mst002-01sen & 0.0330 & 0.0312 & 0.7361 & 0.7757 & 0.7772 & 0.8007 & 0.7758 \\
\hline mst002-02sen & 0.0328 & 0.0443 & 0.7365 & 0.7761 & 0.7776 & 0.8013 & 0.7761 \\
\hline mst002-03sen & 0.0471 & 0.0403 & 0.7465 & 0.7851 & 0.7863 & 0.8091 & 0.7844 \\
\hline mst004-01sen & 0.0408 & 0.0446 & 0.6730 & 0.7108 & 0.7143 & 0.7224 & 0.7191 \\
\hline mst004-02sen & 0.0450 & 0.0418 & 0.6839 & 0.7217 & 0.7251 & 0.7339 & 0.7295 \\
\hline mst004-03sen & 0.0424 & 0.0428 & 0.7013 & 0.7403 & 0.7438 & 0.7551 & 0.7478 \\
\hline
\end{tabular}


Table B-4. Integral index $c_{\mathrm{k}}$ for nominal 21-PWR waste packages and MOX LCEs (continued)

\begin{tabular}{|c|c|c|c|c|c|c|c|}
\hline $\begin{array}{c}\text { Initial } \\
\text { enrichment } \\
\left(w t \%{ }^{235} U\right)\end{array}$ & 2 & 3 & 3 & 3.5 & 4 & 4.5 & 5 \\
\hline $\begin{array}{c}\text { Burnup } \\
\text { (GWd/MTU) }\end{array}$ & $\mathbf{0}$ & $\mathbf{0}$ & 15 & 25 & 30 & 35 & 40 \\
\hline Filename $^{a}$ & $\begin{array}{c}\text { tb2-0 } \\
c_{k} \\
\end{array}$ & $\begin{array}{c}\text { tb3-0 } \\
c_{k} \\
\end{array}$ & $\begin{array}{c}\text { tb15 } \\
c_{k}\end{array}$ & $\begin{array}{c}\text { tb25 } \\
c_{k} \\
\end{array}$ & $\begin{array}{c}\text { tb30 } \\
c_{k} \\
\end{array}$ & $\begin{array}{c}\text { tb35 } \\
c_{k} \\
\end{array}$ & $\begin{array}{c}\text { tb40 } \\
c_{k}\end{array}$ \\
\hline mst004-04sen & 0.0434 & 0.0461 & 0.7055 & 0.7463 & 0.7519 & 0.7642 & 0.7599 \\
\hline mst004-05sen & 0.0465 & 0.0426 & 0.6919 & 0.7316 & 0.7371 & 0.7470 & 0.7452 \\
\hline mst004-06sen & 0.0432 & 0.0429 & 0.6823 & 0.7222 & 0.7279 & 0.7372 & 0.7367 \\
\hline mst004-07sen & 0.0437 & 0.0461 & 0.6926 & 0.7338 & 0.7405 & 0.7527 & 0.7506 \\
\hline mst004-08sen & 0.0467 & 0.0437 & 0.6981 & 0.7391 & 0.7454 & 0.7574 & 0.7550 \\
\hline mst004-09sen & 0.0444 & 0.0380 & 0.7102 & 0.7521 & 0.7586 & 0.7728 & 0.7681 \\
\hline mst005-01sen & 0.0391 & 0.0498 & 0.6901 & 0.7285 & 0.7319 & 0.7436 & 0.7360 \\
\hline mst005-02sen & 0.0501 & 0.0517 & 0.7168 & 0.7554 & 0.7586 & 0.7718 & 0.7619 \\
\hline mst005-03sen & 0.0519 & 0.0506 & 0.7148 & 0.7550 & 0.7604 & 0.7725 & 0.7678 \\
\hline mst005-04sen & 0.0509 & 0.0394 & 0.7184 & 0.7587 & 0.7639 & 0.7772 & 0.7710 \\
\hline $\mathrm{mst} 005-05 \mathrm{sen}$ & 0.0405 & 0.0405 & 0.6963 & 0.7367 & 0.7423 & 0.7554 & 0.7506 \\
\hline mst005-06sen & 0.0418 & 0.0504 & 0.7003 & 0.7417 & 0.7483 & 0.7634 & 0.7581 \\
\hline mst005-07sen & 0.0508 & 0.4484 & 0.7213 & 0.7627 & 0.7687 & 0.7836 & 0.7773 \\
\hline
\end{tabular}

Note: Cell shading identifies critical experiments applicable to bias and bias uncertainty determination.

${ }^{a}$ TSUNAMI-IP and TSUNAMI-3D input and output files for the applications and the experiments are included in the DVD attachment, paths: DVD/ip, DVD/apps/21pwr/sens, and DVD/exps/mox/sens, respectively. 
Table B-5. Integral index $c_{\mathrm{k}}$ for design-basis 21-PWR waste packages and MOX LCEs

\begin{tabular}{|c|c|c|c|c|c|c|c|}
\hline $\begin{array}{c}\text { Initial } \\
\text { enrichment } \\
\left(w t \%{ }^{235} \mathrm{U}\right)\end{array}$ & 2 & 3 & 3 & 3.5 & 4 & 4.5 & 5 \\
\hline $\begin{array}{c}\text { Burnup } \\
\text { (GWd/MTU) }\end{array}$ & $\mathbf{0}$ & $\mathbf{0}$ & 15 & 25 & 30 & 35 & 40 \\
\hline \multirow{2}{*}{ Filename $^{a}$} & $\operatorname{tt} 2-0$ & $\operatorname{tt3}-0$ & $\operatorname{tt} 15$ & $\mathrm{tt} 25$ & tt 30 & tt35 & $\mathrm{tt} 40$ \\
\hline & $\mathbf{c}_{\mathrm{k}}$ & $\mathbf{c}_{\mathbf{k}}$ & $\mathbf{c}_{\mathbf{k}}$ & $\mathbf{c}_{\mathrm{k}}$ & $\mathbf{c}_{\mathbf{k}}$ & $\mathbf{c}_{\mathrm{k}}$ & $\mathbf{c}_{\mathrm{k}}$ \\
\hline $\operatorname{mct} 002-01$ sen & 0.2410 & 0.2302 & 0.8939 & 0.9190 & 0.9221 & 0.9266 & 0.9230 \\
\hline $\operatorname{mct} 002-02$ sen & 0.2380 & 0.2276 & 0.9017 & 0.9264 & 0.9297 & 0.9346 & 0.9312 \\
\hline met $002-03$ sen & 0.2055 & 0.1953 & 0.8473 & 0.8743 & 0.8766 & 0.8803 & 0.8756 \\
\hline met002-04sen & 0.1951 & 0.1856 & 0.8851 & 0.9112 & 0.9138 & 0.9185 & 0.9139 \\
\hline mct002-05sen & 0.1923 & 0.1824 & 0.8315 & 0.8586 & 0.8604 & 0.8639 & 0.8587 \\
\hline mct002-06sen & 0.1828 & 0.1733 & 0.8726 & 0.8987 & 0.9006 & 0.9049 & 0.8997 \\
\hline mct003-01sen & 0.1263 & 0.1222 & 0.8157 & 0.8499 & 0.8567 & 0.8651 & 0.8632 \\
\hline mct $003-02$ sen & 0.1174 & 0.1136 & 0.7994 & 0.8341 & 0.8405 & 0.8484 & 0.8462 \\
\hline $\operatorname{mct} 003-03$ sen & 0.1180 & 0.1143 & 0.8075 & 0.8423 & 0.8490 & 0.8572 & 0.8551 \\
\hline mct003-04sen & 0.0942 & 0.0910 & 0.7548 & 0.7893 & 0.7946 & 0.8013 & 0.7979 \\
\hline met $003-05$ sen & 0.0904 & 0.0872 & 0.7483 & 0.7826 & 0.7876 & 0.7941 & 0.7904 \\
\hline mct003-06sen & 0.0813 & 0.0780 & 0.7442 & 0.7776 & 0.7818 & 0.7877 & 0.7833 \\
\hline mct $004-01$ sen & 0.1835 & 0.1748 & 0.8330 & 0.8631 & 0.8665 & 0.8715 & 0.8671 \\
\hline mct006-01sen & 0.2284 & 0.2178 & 0.8785 & 0.9046 & 0.9075 & 0.9118 & 0.9078 \\
\hline mct007-02sen & 0.2115 & 0.2004 & 0.8494 & 0.8756 & 0.8773 & 0.8805 & 0.8753 \\
\hline met $008-01$ sen & 0.2648 & 0.2519 & 0.9064 & 0.9302 & 0.9326 & 0.9364 & 0.9322 \\
\hline mct $008-02$ sen & 0.2417 & 0.2293 & 0.8774 & 0.9028 & 0.9046 & 0.9080 & 0.9031 \\
\hline mct $008-03$ sen & 0.2287 & 0.2166 & 0.8627 & 0.8882 & 0.8896 & 0.8927 & 0.8874 \\
\hline mct008-04sen & 0.2214 & 0.2093 & 0.8563 & 0.8816 & 0.8828 & 0.8857 & 0.8801 \\
\hline met $008-05$ sen & 0.2119 & 0.1994 & 0.8550 & 0.8793 & 0.8799 & 0.8827 & 0.8766 \\
\hline mct008-06sen & 0.2088 & 0.1962 & 0.8547 & 0.8786 & 0.8790 & 0.8817 & 0.8755 \\
\hline mst001-01sen & 0.0530 & 0.0510 & 0.7445 & 0.7816 & 0.7888 & 0.7976 & 0.7954 \\
\hline mst001-02sen & 0.0530 & 0.0511 & 0.7466 & 0.7836 & 0.7909 & 0.7996 & 0.7974 \\
\hline mst001-03sen & 0.0569 & 0.0554 & 0.7344 & 0.7713 & 0.7785 & 0.7870 & 0.7849 \\
\hline mst001-04sen & 0.0531 & 0.0513 & 0.7470 & 0.7842 & 0.7916 & 0.8005 & 0.7983 \\
\hline mst001-05sen & 0.0527 & 0.0506 & 0.7559 & 0.7931 & 0.8005 & 0.8095 & 0.8073 \\
\hline mst001-06sen & 0.0581 & 0.0565 & 0.7282 & 0.7654 & 0.7728 & 0.7814 & 0.7795 \\
\hline mst001-08sen & 0.0183 & 0.0194 & 0.7012 & 0.7402 & 0.7484 & 0.7579 & 0.7563 \\
\hline mst001-09sen & 0.0195 & 0.0204 & 0.7055 & 0.7436 & 0.7505 & 0.7590 & 0.7563 \\
\hline mst001-10sen & 0.0515 & 0.0496 & 0.7466 & 0.7831 & 0.7897 & 0.7978 & 0.7950 \\
\hline mst001-11sen & 0.0527 & 0.0507 & 0.7479 & 0.7843 & 0.7907 & 0.7988 & 0.7959 \\
\hline mst001-12sen & 0.0499 & 0.0479 & 0.7416 & 0.7778 & 0.7842 & 0.7923 & 0.7894 \\
\hline mst001-13sen & 0.0514 & 0.0494 & 0.7480 & 0.7838 & 0.7894 & 0.7969 & 0.7933 \\
\hline mst002-01sen & 0.0325 & 0.0309 & 0.7397 & 0.7729 & 0.7761 & 0.7822 & 0.7766 \\
\hline mst002-02sen & 0.0324 & 0.0307 & 0.7401 & 0.7733 & 0.7765 & 0.7826 & 0.7769 \\
\hline mst002-03sen & 0.0467 & 0.0438 & 0.7500 & 0.7823 & 0.7852 & 0.7910 & 0.7852 \\
\hline mst004-01sen & 0.0395 & 0.0388 & 0.6724 & 0.7084 & 0.7141 & 0.7212 & 0.7180 \\
\hline mst004-02sen & 0.0443 & 0.0438 & 0.6840 & 0.7197 & 0.7253 & 0.7322 & 0.7289 \\
\hline mst004-03sen & 0.0414 & 0.0407 & 0.7018 & 0.7379 & 0.7435 & 0.7507 & 0.7472 \\
\hline
\end{tabular}


Table B-5. Integral index $c_{k}$ for design-basis 21-PWR waste packages and MOX LCEs (continued)

\begin{tabular}{|c|c|c|c|c|c|c|c|}
\hline $\begin{array}{c}\text { Initial } \\
\text { enrichment } \\
\left(w t \%{ }^{235} U\right)\end{array}$ & 2 & 3 & 3 & 3.5 & 4 & 4.5 & 5 \\
\hline $\begin{array}{c}\text { Burnup } \\
\text { (GWd/MTU) }\end{array}$ & $\mathbf{0}$ & 0 & 15 & 25 & 30 & 35 & 40 \\
\hline Filename $^{a}$ & $\begin{array}{c}t t 2-0 \\
c_{k} \\
\end{array}$ & $\begin{array}{c}t t 3-0 \\
c_{k} \\
\end{array}$ & $\begin{array}{c}\mathrm{tt} 15 \\
\mathrm{c}_{\mathrm{k}}\end{array}$ & $\begin{array}{c}\mathrm{tt} 25 \\
\mathrm{c}_{\mathrm{k}}\end{array}$ & $\begin{array}{c}\mathrm{tt} 30 \\
\mathrm{c}_{\mathrm{k}} \\
\end{array}$ & $\begin{array}{c}\text { tt35 } \\
c_{k}\end{array}$ & $\begin{array}{c}\mathrm{tt} 40 \\
\mathrm{c}_{\mathrm{k}}\end{array}$ \\
\hline mst004-04sen & 0.0425 & 0.0417 & 0.7061 & 0.7441 & 0.7520 & 0.7610 & 0.7594 \\
\hline mst004-05sen & 0.0460 & 0.0454 & 0.6922 & 0.7298 & 0.7376 & 0.7462 & 0.7448 \\
\hline mst004-06sen & 0.0418 & 0.0411 & 0.6819 & 0.7199 & 0.7280 & 0.7369 & 0.7357 \\
\hline mst004-07sen & 0.0425 & 0.0416 & 0.6928 & 0.7315 & 0.7405 & 0.7504 & 0.7499 \\
\hline mst004-08sen & 0.0461 & 0.0454 & 0.6987 & 0.7371 & 0.7458 & 0.7554 & 0.7546 \\
\hline mst004-09sen & 0.0436 & 0.0427 & 0.7111 & 0.7498 & 0.7586 & 0.7685 & 0.7677 \\
\hline mst005-01sen & 0.0380 & 0.0369 & 0.6904 & 0.7261 & 0.7317 & 0.7388 & 0.7354 \\
\hline mst005-02sen & 0.0509 & 0.0503 & 0.7188 & 0.7540 & 0.7593 & 0.7661 & 0.7625 \\
\hline mst005-03sen & 0.0524 & 0.0520 & 0.7164 & 0.7537 & 0.7613 & 0.7699 & 0.7682 \\
\hline mst005-04sen & 0.0517 & 0.0512 & 0.7204 & 0.7575 & 0.7649 & 0.7734 & 0.7716 \\
\hline mst005-05sen & 0.0395 & 0.0383 & 0.6968 & 0.7344 & 0.7424 & 0.7515 & 0.7501 \\
\hline mst005-06sen & 0.0409 & 0.0396 & 0.7012 & 0.7394 & 0.7484 & 0.7584 & 0.7578 \\
\hline mst005-07sen & 0.0516 & 0.0509 & 0.7235 & 0.7613 & 0.7697 & 0.7790 & 0.7780 \\
\hline
\end{tabular}

Note: Cell shading identifies critical experiments applicable to bias and bias uncertainty determination.

${ }^{a}$ TSUNAMI-IP and TSUNAMI-3D input and output files for the applications and the experiments are included in the DVD attachment, paths: DVD/ip, DVD/apps/21pwr/sens, and DVD/exps/mox/sens, respectively. 
Table B-6. Integral index $c_{k}$ for 44-BWR waste packages and MOX LCEs

\begin{tabular}{|c|c|c|c|c|c|c|c|c|c|c|}
\hline & \multicolumn{5}{|c|}{ Nominal configurations } & \multicolumn{5}{|c|}{ Design-basis configurations } \\
\hline $\begin{array}{c}\begin{array}{c}\text { Initial } \\
\text { enrichment } \\
\left(\text { wt } \%{ }^{235} U\right)\end{array} \\
\end{array}$ & 3 & 3 & 4 & 4 & 5 & 3 & 3 & 4 & 4 & 5 \\
\hline $\begin{array}{c}\text { Burnup } \\
\text { (GWd/MTU) }\end{array}$ & $\mathbf{0}$ & 10 & $\mathbf{0}$ & 20 & 30 & $\mathbf{0}$ & 10 & $\mathbf{0}$ & 20 & 30 \\
\hline & tb3-0 & tb3-10 & tb4-0 & tb4-20 & tb5-30 & tt3-0 & tt3-10 & tt4-0 & tt4-20 & tt5-30 \\
\hline & $\mathbf{c}_{\mathrm{k}}$ & $\mathbf{c}_{\mathrm{k}}$ & $\mathbf{c}_{\mathrm{k}}$ & $\mathbf{c}_{\mathrm{k}}$ & $\mathbf{c}_{\mathrm{k}}$ & $\mathbf{c}_{\mathrm{k}}$ & $\mathbf{c}_{\mathrm{k}}$ & $\mathbf{c}_{\mathrm{k}}$ & $\mathbf{c}_{\mathrm{k}}$ & $\mathbf{c}_{\mathrm{k}}$ \\
\hline met002-01sen & 0.2233 & 0.9335 & 0.2121 & 0.9460 & 0.9439 & 0.2210 & 0.9308 & 0.2095 & 0.9448 & 0.9439 \\
\hline mct002-02sen & 0.2219 & 0.9448 & 0.2111 & 0.9592 & 0.9581 & 0.2196 & 0.9422 & 0.2085 & 0.9577 & 0.9574 \\
\hline mct002-03sen & 0.1877 & 0.8841 & 0.1773 & 0.8941 & 0.8901 & 0.1858 & 0.8815 & 0.1751 & 0.8936 & 0.8915 \\
\hline mct002-04sen & 0.1807 & 0.9319 & 0.1711 & 0.9470 & 0.9451 & 0.1791 & 0.9299 & 0.1693 & 0.9459 & 0.9449 \\
\hline mct002-05sen & 0.1749 & 0.8679 & 0.1648 & 0.8775 & 0.8731 & 0.1732 & 0.8654 & 0.1629 & 0.8772 & 0.8748 \\
\hline mct002-06sen & 0.1683 & 0.9187 & 0.1588 & 0.9331 & 0.9304 & 0.1669 & 0.9169 & 0.1573 & 0.9322 & 0.9306 \\
\hline mct003-01sen & 0.1189 & 0.8774 & 0.1140 & 0.9033 & 0.9060 & 0.1172 & 0.8743 & 0.1120 & 0.9020 & 0.9062 \\
\hline mct003-02sen & 0.1100 & 0.8585 & 0.1055 & 0.8822 & 0.8836 & 0.1084 & 0.8554 & 0.1035 & 0.8813 & 0.8846 \\
\hline mct003-03sen & 0.1110 & 0.8685 & 0.1065 & 0.8935 & 0.8955 & 0.1094 & 0.8655 & 0.1045 & 0.8924 & 0.8961 \\
\hline mct003-04sen & 0.0874 & 0.8087 & 0.0837 & 0.8283 & 0.8273 & 0.0861 & 0.8059 & 0.0820 & 0.8279 & 0.8294 \\
\hline mct003-05sen & & 0.8014 & & 0.8204 & & & 7987 & 0784 & 8201 & 0.8212 \\
\hline mct003-06sen & 0.0746 & 0.7968 & 0.071 & 0.8151 & 0.8130 & 0.0736 & 0.7945 & 0.0697 & 0.8149 & 0.8152 \\
\hline mct004-01sen & 0.1673 & 0.8692 & 0.15 & 0.8819 & 0.8793 & 0.1656 & 0.8667 & 0.1 & 0.8816 & 0.8810 \\
\hline mct006-01sen & & $0.91^{\prime}$ & & 0.9285 & 0.92 & 0 & 0.91 & 71 & 276 & 0.9262 \\
\hline mct007-02sen & 0.1924 & 0.8822 & 0.1813 & 0.8910 & 0.8867 & 0.1907 & 0.8798 & 0.1793 & 0.8906 & 0.8881 \\
\hline mct008-01sen & 0.2442 & 0.9374 & 0.2311 & 0.9471 & 0.9444 & 0.2419 & 0.9348 & 0.2285 & 0.9461 & 0.9444 \\
\hline mct008-02sen & & 0.9067 & & 0.9151 & 0.9112 & & 0.9042 & & 9145 & 0.9122 \\
\hline mct008-03sen & 0.2082 & 0.8916 & 0.1960 & 0.8997 & 0.8954 & 0.2064 & 0.8893 & 0.1940 & 0.8993 & 0.8966 \\
\hline mct008-04sen & 0.2010 & 0.8855 & 0.1889 & 0.8935 & 0.8891 & 0.1994 & 0.8833 & 0.1871 & 0.8932 & 0.8904 \\
\hline mct008-05sen & & 0.8856 & & 0.8944 & 0.8900 & & 0.8840 & & 8940 & 0.8910 \\
\hline mct008-06sen & 0.1888 & 0.8861 & 0.1767 & 0.8951 & 0.8908 & 0.1876 & 0.8846 & 0.1754 & 0.8948 & 0.8917 \\
\hline mst001-01sen & 0.0494 & 0.8104 & 0.0473 & 0.8359 & 0.8370 & 0.04 & 0.8083 & 0.0470 & 0.8359 & 0.8393 \\
\hline mst001-02sen & 0.0495 & 0.8128 & & 0.8384 & 0.8395 & 0.049 & 0.8107 & 0.0471 & 0.8384 & 0.8418 \\
\hline mst001-03sen & 0.0552 & 0.7992 & 0.0533 & 0.8234 & 0.8241 & 0.0559 & 0.7974 & 0.0536 & 0.8239 & 0.8271 \\
\hline mst001-04sen & 0.0497 & 0.8136 & 0.0477 & 0.8395 & 0.8408 & 0.0498 & 0.8115 & 0.0474 & 0.8395 & 0.8431 \\
\hline mst001-05sen & 0.0489 & 0.8237 & & 0.8504 & 0.8519 & 0.0489 & 0.8216 & 0.0464 & 0.8502 & 0.8539 \\
\hline mst001-06sen & 0.05 & 0.7916 & 0.05 & 0.8158 & 0.8166 & 0.05 & 0.7894 & 0.0530 & 0.8160 & 0.8194 \\
\hline mst001-08sen & 0.0200 & 0.7715 & 0.0206 & 0.7989 & 0.8006 & 0.0202 & 0.7693 & 0.0204 & 0.7990 & 0.8034 \\
\hline mst001-09sen & 0.0210 & 0.7725 & 0.0215 & 0.7974 & 0.7978 & 0.0212 & 0.7705 & 0.0213 & 0.7977 & 0.8007 \\
\hline mst001-10sen & 0.0480 & 0.8108 & 0.0460 & 0.8349 & 0.8351 & 0.0481 & 0.8088 & 0.0457 & 0.8350 & 0.8375 \\
\hline mst001-11sen & 0.0489 & 0.8115 & 0.0469 & 0.8351 & 0.8351 & 0.0489 & 0.8095 & 0.0464 & 0.8353 & 0.8376 \\
\hline mst001-12sen & 0.0463 & 0.8053 & 0.0443 & 0.8289 & 0.8288 & 0.0463 & 0.8033 & 0.0439 & 0.8291 & 0.8314 \\
\hline mst001-13sen & 0.0478 & 0.8101 & 0.0458 & 0.8326 & 0.8321 & 0.0479 & 0.8083 & 0.0456 & 0.8328 & 0.8346 \\
\hline mst002-01sen & 0.0292 & 0.7991 & 0.0279 & 0.8207 & 0.8194 & 0.0292 & 0.7980 & 0.0277 & 0.8206 & 0.8210 \\
\hline mst002-02sen & 0.0291 & 0.7996 & 0.0277 & 0.8213 & 0.8200 & 0.0291 & 0.7986 & 0.0276 & 0.8212 & 0.8216 \\
\hline mst002-03sen & 0.0413 & 0.8070 & 0.0389 & 0.8274 & 0.8258 & 0.0413 & 0.8059 & 0.0387 & 0.8274 & 0.8275 \\
\hline mst004-01sen & 0.0363 & 0.7267 & 0.0354 & 0.7460 & 0.7446 & 0.0355 & 0.7240 & 0.0341 & 0.7462 & 0.7477 \\
\hline mst004-02sen & 0.0428 & 0.7394 & 0.0419 & 0.7584 & 0.7569 & 0.0429 & 0.7373 & 0.0415 & 0.7590 & 0.7604 \\
\hline mst004-03sen & 0.0389 & 0.7592 & & 0.7796 & 0.7785 & 0.0386 & 0.7569 & 0.0371 & 0.7798 & 0.7814 \\
\hline mst004-04sen & 0.0399 & 0.7701 & 0.0388 & 0.7954 & 0.7966 & 0.0396 & 0.7676 & 0.0381 & 0.7953 & 0.7992 \\
\hline
\end{tabular}


Table B-6. Integral index $c_{k}$ for 44-BWR waste packages and MOX LCEs (continued)

\begin{tabular}{|c|c|c|c|c|c|c|c|c|c|c|}
\hline & \multicolumn{5}{|c|}{ Nominal configurations } & \multicolumn{5}{|c|}{ Design-basis configurations } \\
\hline $\begin{array}{c}\text { Initial } \\
\text { enrichment } \\
\left(w t \%{ }^{235} U\right)\end{array}$ & 3 & 3 & 4 & 4 & 5 & 3 & 3 & 4 & 4 & 5 \\
\hline $\begin{array}{c}\text { Burnup } \\
(\text { GWd/MTU) }\end{array}$ & $\mathbf{0}$ & 10 & $\mathbf{0}$ & 20 & 30 & $\mathbf{0}$ & 10 & $\mathbf{0}$ & 20 & 30 \\
\hline Filename $a$ & tb3-0 & tb3-10 & tb4-0 & tb4-20 & tb5-30 & tt3-0 & tt3-10 & tt4-0 & tt4-20 & tt5-30 \\
\hline 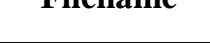 & $\mathbf{c}_{\mathrm{k}}$ & $c_{k}$ & $\mathbf{c}_{\mathrm{k}}$ & $c_{k}$ & $c_{k}$ & $c_{\mathrm{k}}$ & $\mathbf{c}_{\mathrm{k}}$ & $\mathbf{c}_{\mathrm{k}}$ & $\mathbf{c}_{\mathrm{k}}$ & $c_{k}$ \\
\hline mst004-05sen & 0.0446 & 0.7543 & 0.0436 & 0.7781 & 0.7789 & 0.0447 & 0.7520 & 0.0432 & 0.7784 & 0.7821 \\
\hline mst004-06sen & 0.0385 & 0.7431 & 0.0375 & 0.7675 & 0.7687 & 0.0377 & 0.7402 & 0.0361 & 0.7673 & 0.7714 \\
\hline mst004-07sen & 0.0390 & 0.7586 & 0.0378 & 0.7866 & 0.7896 & 0.0383 & 0.7556 & 0.0366 & 0.7861 & 0.7917 \\
\hline mst004-08sen & 0.0443 & 0.7646 & 0.0431 & 0.7915 & 0.7940 & 0.0443 & 0.7620 & 0.0427 & 0.7915 & 0.7966 \\
\hline mst004-09sen & 0.0409 & 0.7789 & 0.0397 & 0.8072 & 0.8102 & 0.0406 & 0.7762 & 0.0390 & 0.8069 & 0.8123 \\
\hline mst005-01sen & 0.0348 & 0.7474 & 0.0337 & 0.7677 & 0.7664 & 0.0343 & 0.7450 & 0.0327 & 0.7679 & 0.7695 \\
\hline mst005-02sen & 0.0527 & 0.7790 & 0.0516 & 0.7987 & 0.7973 & 0.0543 & 0.7780 & 0.0529 & 0.7999 & 0.8011 \\
\hline mst005-03sen & 0.0538 & 0.7815 & 0.0528 & 0.8054 & 0.8062 & 0.0552 & 0.7801 & 0.0538 & 0.8063 & 0.8097 \\
\hline mst005-04sen & 0.0535 & 0.7864 & 0.0524 & 0.8104 & 0.8110 & 0.0551 & 0.7851 & 0.0536 & 0.8114 & 0.8147 \\
\hline mst005-05sen & 0.0363 & 0.7609 & 0.0350 & 0.7864 & 0.7877 & 0.0357 & 0.7582 & 0.0340 & 0.7863 & 0.7904 \\
\hline mst005-06sen & 0.0375 & 0.7690 & 0.0360 & 0.7977 & 0.8008 & 0.0369 & 0.7661 & 0.0351 & 0.7973 & 0.8030 \\
\hline mst005-07sen & 0.0529 & 0.7927 & 0.0517 & 0.8196 & 0.8218 & 0.0543 & 0.7912 & 0.0528 & 0.8203 & 0.8250 \\
\hline
\end{tabular}

Note: Cell shading identifies critical experiments applicable to bias and bias uncertainty determination.

${ }^{a}$ TSUNAMI-IP and TSUNAMI-3D input and output files for the applications and the experiments are included in the DVD attachment, paths: DVD/ip, DVD/apps/44bwr/sens, and DVD/exps/mox/sens, respectively. 
Table B-7. Integral index $c_{\mathrm{k}}$ for nominal 21-PWR waste packages and LEU LCEs

\begin{tabular}{|c|c|c|c|c|c|c|c|}
\hline $\begin{array}{c}\text { Initial } \\
\text { enrichment } \\
\left(\text { wt } \%{ }^{235} U\right)\end{array}$ & 2 & 3 & 3 & 3.5 & 4 & 4.5 & 5 \\
\hline $\begin{array}{c}\text { Burnup } \\
\text { (GWd/MTU) }\end{array}$ & $\mathbf{0}$ & $\mathbf{0}$ & 15 & 25 & 30 & 35 & 40 \\
\hline Filename $^{a}$ & $\begin{array}{c}\text { tb2-0 } \\
c_{k}\end{array}$ & $\begin{array}{c}\text { tb3-0 } \\
\mathbf{c}_{\mathrm{k}}\end{array}$ & $\begin{array}{c}\text { tb15 } \\
c_{k}\end{array}$ & $\begin{array}{c}\text { tb25 } \\
c_{k}\end{array}$ & $\begin{array}{c}\text { tb30 } \\
\mathbf{c}_{\mathrm{k}}\end{array}$ & $\begin{array}{c}\text { tb35 } \\
c_{k}\end{array}$ & $\begin{array}{c}\text { tb40 } \\
c_{k}\end{array}$ \\
\hline lct010c5 & 0.8654 & 0.8804 & 0.5196 & 0.4595 & 0.4517 & 0.3601 & 0.4453 \\
\hline lct010c16 & 0.8391 & 0.8730 & 0.5173 & 0.4606 & 0.4555 & 0.3608 & 0.4546 \\
\hline lct010c17 & 0.8318 & 0.8728 & 0.5126 & 0.4566 & 0.4515 & 0.3569 & 0.4506 \\
\hline lct010c18 & 0.8321 & 0.8575 & 0.5121 & 0.4559 & 0.4507 & 0.3562 & 0.4497 \\
\hline lct010c19 & 0.8168 & 0.9174 & 0.5023 & 0.4474 & 0.4421 & 0.3482 & 0.4413 \\
\hline lct017-03 & 0.8703 & 0.8748 & 0.5174 & 0.4557 & 0.4452 & 0.3555 & 0.4347 \\
\hline lct017-04 & 0.9229 & 0.9173 & 0.5510 & 0.4848 & 0.4733 & 0.3847 & 0.4603 \\
\hline lct017-05 & 0.9053 & 0.9024 & 0.5404 & 0.4759 & 0.4646 & 0.3754 & 0.4523 \\
\hline lct017-06 & 0.9009 & 0.8985 & 0.5378 & 0.4737 & 0.4624 & 0.3731 & 0.4503 \\
\hline lct017-07 & 0.8939 & 0.8925 & 0.5335 & 0.4700 & 0.4588 & 0.3694 & 0.4469 \\
\hline $1 \mathrm{ct} 17 \mathrm{c} 8$ & 0.8796 & 0.8812 & 0.5236 & 0.4612 & 0.4504 & 0.3608 & 0.4392 \\
\hline lct017-09 & 0.8631 & 0.8677 & 0.5138 & 0.4528 & 0.4424 & 0.3525 & 0.4321 \\
\hline lct017-10 & 0.8962 & 0.9006 & 0.5347 & 0.4711 & 0.4605 & 0.3698 & 0.4496 \\
\hline lct017-11 & 0.8923 & 0.8966 & 0.5321 & 0.4687 & 0.4581 & 0.3675 & 0.4473 \\
\hline lct017-12 & 0.8876 & 0.8919 & 0.5290 & 0.4660 & 0.4554 & 0.3649 & 0.4446 \\
\hline lct017-13 & 0.8806 & 0.8850 & 0.5243 & 0.4619 & 0.4513 & 0.3609 & 0.4406 \\
\hline lct017-14 & 0.8774 & 0.8816 & 0.5220 & 0.4598 & 0.4492 & 0.3590 & 0.4385 \\
\hline lct017-15 & 0.9427 & 0.9455 & 0.5742 & 0.5074 & 0.4968 & 0.4062 & 0.4853 \\
\hline lct017-16 & 0.9373 & 0.9401 & 0.5705 & 0.5042 & 0.4935 & 0.4027 & 0.4820 \\
\hline lct17c17 & 0.9386 & 0.9406 & 0.5698 & 0.5033 & 0.4925 & 0.4017 & 0.4809 \\
\hline lct017-19 & 0.9354 & 0.9370 & 0.5670 & 0.5006 & 0.4898 & 0.3991 & 0.4781 \\
\hline lct017-20 & 0.9323 & 0.9340 & 0.5648 & 0.4987 & 0.4878 & 0.3970 & 0.4762 \\
\hline lct017-21 & 0.9283 & 0.9302 & 0.5619 & 0.4962 & 0.4853 & 0.3946 & 0.4739 \\
\hline lct017-22 & 0.9138 & 0.9168 & 0.5536 & 0.4892 & 0.4784 & 0.3876 & 0.4674 \\
\hline lct017-23 & 0.9220 & 0.9237 & 0.5582 & 0.4926 & 0.4818 & 0.3927 & 0.4703 \\
\hline lct017-24 & 0.9213 & 0.9231 & 0.5573 & 0.4918 & 0.4810 & 0.3916 & 0.4695 \\
\hline lct017-25 & 0.9239 & 0.9252 & 0.5579 & 0.4922 & 0.4813 & 0.3913 & 0.4697 \\
\hline lct017-28 & 0.9454 & 0.9391 & 0.5727 & 0.5053 & 0.4937 & 0.4053 & 0.4804 \\
\hline lct017-29 & 0.9414 & 0.9363 & 0.5696 & 0.5024 & 0.4909 & 0.4022 & 0.4779 \\
\hline $1 \mathrm{ct} 26 \mathrm{c} 3$ & 0.8281 & 0.8809 & 0.5314 & 0.4763 & 0.4740 & 0.3840 & 0.4768 \\
\hline lct42c1 & 0.9444 & 0.9470 & 0.5748 & 0.5079 & 0.4971 & 0.4064 & 0.4854 \\
\hline $1 \mathrm{ct} 42 \mathrm{c} 2$ & 0.9513 & 0.9526 & 0.5774 & 0.5096 & 0.4988 & 0.4086 & 0.4868 \\
\hline $1 \mathrm{ct} 42 \mathrm{c} 3$ & 0.9542 & 0.9554 & 0.5791 & 0.5110 & 0.5002 & 0.4102 & 0.4882 \\
\hline lct42c4 & 0.9529 & 0.9539 & 0.5785 & 0.5105 & 0.4997 & 0.4096 & 0.4876 \\
\hline $1 \mathrm{ct} 42 \mathrm{c} 5$ & 0.9516 & 0.9530 & 0.5774 & 0.5095 & 0.4987 & 0.4086 & 0.4868 \\
\hline lct $42 \mathrm{c} 6$ & 0.9414 & 0.9431 & 0.5711 & 0.5041 & 0.4934 & 0.4030 & 0.4816 \\
\hline lct $42 \mathrm{c} 7$ & 0.9494 & 0.9505 & 0.5756 & 0.5078 & 0.4970 & 0.4069 & 0.4850 \\
\hline
\end{tabular}

Note: Cell shading identifies critical experiments applicable to bias and bias uncertainty determination.

${ }^{a}$ TSUNAMI-IP and TSUNAMI-3D input and output files for the applications and the experiments are included in the DVD attachment, paths: DVD/ip, DVD/apps/21pwr/sens, and DVD/exps/leu/sens, respectively. 
Table B-8. Integral index $c_{k}$ for design-basis 21-PWR waste packages and LEU LCEs

\begin{tabular}{|c|c|c|c|c|c|c|c|}
\hline $\begin{array}{c}\text { Initial } \\
\text { enrichment } \\
\left(\text { wt } \%{ }^{235} U\right)\end{array}$ & 2 & 3 & 3 & 3.5 & 4 & 4.5 & 5 \\
\hline $\begin{array}{c}\text { Burnup } \\
\text { (GWd/MTU) }\end{array}$ & $\mathbf{0}$ & $\mathbf{0}$ & 15 & 25 & 30 & 35 & 40 \\
\hline Filename $^{a}$ & $\begin{array}{c}\mathrm{tt} 2-0 \\
\mathrm{c}_{\mathrm{k}}\end{array}$ & $\begin{array}{c}t t 3-0 \\
c_{k}\end{array}$ & $\begin{array}{c}t 115 \\
c_{k}\end{array}$ & $\begin{array}{c}t \mathrm{t} 25 \\
\mathrm{c}_{\mathrm{k}}\end{array}$ & $\begin{array}{c}t \text { t30 } \\
c_{k}\end{array}$ & $\begin{array}{c}\mathrm{tt} 35 \\
\mathbf{c}_{\mathrm{k}}\end{array}$ & $\begin{array}{c}\mathrm{tt} 40 \\
\mathrm{c}_{\mathrm{k}}\end{array}$ \\
\hline lct010c5 & 0.8602 & 0.8733 & 0.5026 & 0.4618 & 0.4516 & 0.4338 & 0.4370 \\
\hline lct010c16 & 0.8348 & 0.8700 & 0.5000 & 0.4634 & 0.4562 & 0.4404 & 0.4461 \\
\hline lct010c17 & 0.8274 & 0.8622 & 0.4952 & 0.4592 & 0.4521 & 0.4365 & 0.4420 \\
\hline lct010c18 & 0.8276 & 0.8619 & 0.4946 & 0.4585 & 0.4513 & 0.4357 & 0.4411 \\
\hline lct010c19 & 0.8121 & 0.8460 & 0.4846 & 0.4498 & 0.4427 & 0.4273 & 0.4326 \\
\hline lct017-03 & 0.8665 & 0.8655 & 0.5015 & 0.4587 & 0.4462 & 0.4269 & 0.4275 \\
\hline lct017-04 & 0.9189 & 0.9098 & 0.5358 & 0.4877 & 0.4738 & 0.4532 & 0.4534 \\
\hline lct017-05 & 0.9013 & 0.8940 & 0.5249 & 0.4788 & 0.4653 & 0.4451 & 0.4453 \\
\hline lct017-06 & 0.8969 & 0.8900 & 0.5222 & 0.4765 & 0.4631 & 0.4430 & 0.4432 \\
\hline lct017-07 & 0.8900 & 0.8838 & 0.5178 & 0.4728 & 0.4596 & 0.4396 & 0.4398 \\
\hline lct $17 \mathrm{c} 8$ & 0.8758 & 0.8722 & 0.5078 & 0.4641 & 0.4513 & 0.4317 & 0.4321 \\
\hline lct017-09 & 0.8593 & 0.8581 & 0.4977 & 0.4557 & 0.4434 & 0.4242 & 0.4248 \\
\hline lct017-10 & 0.8930 & 0.8924 & 0.5192 & 0.4743 & 0.4616 & 0.4418 & 0.4427 \\
\hline lct017-11 & 0.8889 & 0.8882 & 0.5165 & 0.4719 & 0.4592 & 0.4394 & 0.4403 \\
\hline lct017-12 & 0.8841 & 0.8832 & 0.5133 & 0.4691 & 0.4565 & 0.4368 & 0.4376 \\
\hline lct017-13 & 0.8770 & 0.8760 & 0.5085 & 0.4649 & 0.4523 & 0.4328 & 0.4335 \\
\hline lct017-14 & 0.8737 & 0.8725 & 0.5061 & 0.4628 & 0.4502 & 0.4307 & 0.4314 \\
\hline lct017-15 & 0.9398 & 0.9392 & 0.5596 & 0.5109 & 0.4979 & 0.4774 & 0.4787 \\
\hline lct017-16 & 0.9342 & 0.9333 & 0.5556 & 0.5076 & 0.4945 & 0.4742 & 0.4753 \\
\hline lct17c17 & 0.9353 & 0.9338 & 0.5549 & 0.5066 & 0.4935 & 0.4730 & 0.4741 \\
\hline lct017-19 & 0.9319 & 0.9299 & 0.5519 & 0.5038 & 0.4906 & 0.4703 & 0.4712 \\
\hline lct017-20 & 0.9288 & 0.9266 & 0.5495 & 0.5018 & 0.4886 & 0.4683 & 0.4692 \\
\hline lct017-21 & 0.9246 & 0.9226 & 0.5466 & 0.4992 & 0.4861 & 0.4659 & 0.4668 \\
\hline lct017-22 & 0.9099 & 0.9085 & 0.5379 & 0.4921 & 0.4792 & 0.4594 & 0.4602 \\
\hline lct017-23 & 0.9183 & 0.9164 & 0.5431 & 0.4956 & 0.4826 & 0.4626 & 0.4634 \\
\hline lct017-24 & 0.9175 & 0.9156 & 0.5421 & 0.4948 & 0.4818 & 0.4617 & 0.4626 \\
\hline lct017-25 & 0.9201 & 0.9176 & 0.5426 & 0.4952 & 0.4821 & 0.4619 & 0.4627 \\
\hline lct017-28 & 0.9415 & 0.9325 & 0.5580 & 0.5082 & 0.4941 & 0.4733 & 0.4736 \\
\hline lct017-29 & 0.9375 & 0.9295 & 0.5547 & 0.5054 & 0.4915 & 0.4707 & 0.4711 \\
\hline lct26c3 & 0.8242 & 0.8734 & 0.5158 & 0.4792 & 0.4744 & 0.4607 & 0.4687 \\
\hline lct42c1 & 0.9425 & 0.9416 & 0.5608 & 0.5120 & 0.4988 & 0.4783 & 0.4794 \\
\hline $1 \mathrm{ct} 42 \mathrm{c} 2$ & 0.9484 & 0.9467 & 0.5630 & 0.5131 & 0.4998 & 0.4791 & 0.4803 \\
\hline lct42c3 & 0.9511 & 0.9495 & 0.5647 & 0.5144 & 0.5011 & 0.4805 & 0.4817 \\
\hline lct $42 \mathrm{c} 4$ & 0.9498 & 0.9480 & 0.5640 & 0.5139 & 0.5006 & 0.4799 & 0.4810 \\
\hline $1 \mathrm{ct} 42 \mathrm{c} 5$ & 0.9486 & 0.9470 & 0.5629 & 0.5130 & 0.4997 & 0.4790 & 0.4802 \\
\hline lct42c6 & 0.9382 & 0.9366 & 0.5563 & 0.5075 & 0.4943 & 0.4738 & 0.4749 \\
\hline lct $42 \mathrm{c} 7$ & 0.9462 & 0.9444 & 0.5610 & 0.5112 & 0.4979 & 0.4773 & 0.4784 \\
\hline
\end{tabular}

Note: Cell shading identifies critical experiments applicable to bias and bias uncertainty determination.

${ }^{a}$ TSUNAMI-IP and TSUNAMI-3D input and output files for the applications and the experiments are included in the DVD attachment, paths: DVD/ip, DVD/apps/21pwr/sens, and DVD/exps/leu/sens, respectively. 
Table B-9. Integral index $c_{k}$ for 44-BWR waste packages and LEU LCEs

\begin{tabular}{|c|c|c|c|c|c|c|c|c|c|c|}
\hline & \multicolumn{5}{|c|}{ Nominal configurations } & \multicolumn{5}{|c|}{ Design-basis configurations } \\
\hline $\begin{array}{c}\text { Initial } \\
\text { enrichment } \\
\left(\text { wt } \%{ }^{235} U\right)\end{array}$ & 3 & 3 & 4 & 4 & 5 & 3 & 3 & 4 & 4 & 5 \\
\hline $\begin{array}{c}\text { Burnup } \\
\text { (GWd/MTU) }\end{array}$ & $\mathbf{0}$ & 10 & $\mathbf{0}$ & 20 & 30 & $\mathbf{0}$ & 10 & $\mathbf{0}$ & 20 & 30 \\
\hline Filename $\mathrm{e}^{a}$ & tb3-0 & tb3-10 & tb4-0 & tb4-20 & tb5-30 & tt 3-0 & tt3-10 & tt4-0 & tt4-20 & tt5-30 \\
\hline & $\mathbf{c}_{\mathrm{k}}$ & $\mathbf{c}_{\mathrm{k}}$ & $\mathbf{c}_{\mathrm{k}}$ & $\mathbf{c}_{\mathrm{k}}$ & $\mathbf{c}_{\mathrm{k}}$ & $\mathbf{c}_{\mathrm{k}}$ & $\mathbf{c}_{\mathrm{k}}$ & $\mathbf{c}_{\mathrm{k}}$ & $\mathbf{c}_{\mathrm{k}}$ & $\mathbf{c}_{\mathrm{k}}$ \\
\hline $1 \mathrm{ct} 010 \mathrm{c} 5$ & 0.8575 & 0.3792 & 0.8497 & 0.3052 & 0.2857 & 0.8491 & 0.3747 & 0.8424 & 0.3039 & 0.2851 \\
\hline lct010c16 & 0.8493 & 0.3837 & 0.8589 & 0.3133 & 0.2955 & 0.8421 & 0.3797 & 0.8526 & 0.3130 & 0.2961 \\
\hline lct010c17 & 0.8401 & 0.3789 & 0.8495 & 0.3091 & 0.2914 & 0.8326 & 0.3747 & 0.8428 & 0.3086 & 0.2918 \\
\hline $1 \mathrm{ct} 010 \mathrm{c} 18$ & 0.8395 & 0.3779 & 0.8485 & 0.3080 & 0.2903 & 0.8319 & 0.3737 & 0.8417 & 0.3075 & 0.2906 \\
\hline $1 \mathrm{ct} 010 \mathrm{c} 19$ & 0.8217 & 0.3687 & 0.8304 & 0.3001 & 0.2826 & 0.8138 & 0.3643 & 0.8233 & 0.2994 & 0.2828 \\
\hline lct017-03 & 0.8362 & 0.3665 & 0.8176 & 0.2907 & 0.2696 & 0.8303 & 0.3635 & 0.8128 & 0.2908 & 0.2705 \\
\hline lct017-04 & 0.8871 & 0.3953 & 0.8632 & 0.3152 & 0.2931 & 0.8806 & 0.3921 & 0.8575 & 0.3147 & 0.2931 \\
\hline lct017-05 & 0.8689 & 0.3859 & 0.8462 & 0.3072 & 0.2854 & 0.8626 & 0.3827 & 0.8407 & 0.3068 & 0.2857 \\
\hline lct017-06 & 0.8643 & 0.3836 & 0.8417 & 0.3051 & 0.2834 & 0.8580 & 0.3803 & 0.8363 & 0.3048 & 0.2837 \\
\hline lct017-07 & 0.8572 & 0.3798 & 0.8350 & 0.3019 & 0.2803 & 0.8509 & 0.3766 & 0.8298 & 0.3017 & 0.2808 \\
\hline lct17c8 & 0.8440 & 0.3716 & 0.8236 & 0.2949 & 0.2736 & 0.8380 & 0.3685 & 0.8187 & 0.2949 & 0.2743 \\
\hline lct017-09 & 0.8287 & 0.3636 & 0.8100 & 0.2883 & 0.2674 & 0.8228 & 0.3605 & 0.8053 & 0.2884 & 0.2683 \\
\hline lct017-10 & 0.8672 & 0.3835 & 0.8487 & 0.3055 & 0.2840 & 0.8624 & 0.3811 & 0.8449 & 0.3061 & 0.2853 \\
\hline lct017-11 & 0.8622 & 0.3807 & 0.8436 & 0.3031 & 0.2816 & 0.8573 & 0.3783 & 0.8398 & 0.3036 & 0.2829 \\
\hline lct017-12 & 0.8564 & 0.3776 & 0.8377 & 0.3003 & 0.2789 & 0.8513 & 0.3750 & 0.8337 & 0.3008 & 0.2801 \\
\hline $1 \operatorname{ct} 017-13$ & 0.8482 & 0.3731 & 0.8294 & 0.2963 & 0.2751 & 0.8427 & 0.3703 & 0.8251 & 0.2966 & 0.2762 \\
\hline lct017-14 & 0.8441 & 0.3707 & 0.8253 & 0.2943 & 0.2730 & 0.8386 & 0.3679 & 0.8208 & 0.2945 & 0.2741 \\
\hline lct017-15 & 0.9184 & 0.4203 & 0.9014 & 0.3391 & 0.3172 & 0.9137 & 0.4181 & 0.8972 & 0.3397 & 0.3182 \\
\hline $1 \mathrm{ct} 017-16$ & 0.9108 & 0.4160 & 0.8934 & 0.3351 & 0.3133 & 0.9059 & 0.4135 & 0.8890 & 0.3356 & 0.3142 \\
\hline lct17c17 & 0.9108 & 0.4145 & 0.8930 & 0.3335 & 0.3116 & 0.9055 & 0.4119 & 0.8882 & 0.3339 & 0.3124 \\
\hline lct017-19 & 0.9055 & 0.4108 & 0.8872 & 0.3301 & 0.3082 & 0.8998 & 0.4080 & 0.8821 & 0.3302 & 0.3087 \\
\hline lct017-20 & 0.9017 & 0.4085 & 0.8833 & 0.3280 & 0.3061 & 0.8957 & 0.4055 & 0.8780 & 0.3280 & 0.3066 \\
\hline lct017-21 & 0.8970 & 0.4057 & 0.8788 & 0.3256 & 0.3038 & 0.8909 & 0.4026 & 0.8732 & 0.3255 & 0.3042 \\
\hline $1 \operatorname{ct} 017-22$ & 0.8812 & 0.3981 & 0.8633 & 0.3191 & 0.2976 & 0.8747 & 0.3947 & 0.8576 & 0.3190 & 0.2980 \\
\hline lct017-23 & 0.8902 & 0.4027 & 0.8725 & 0.3232 & 0.3017 & 0.8837 & 0.3994 & 0.8665 & 0.3230 & 0.3018 \\
\hline $1 \mathrm{ct} 017-24$ & 0.8893 & 0.4017 & 0.8714 & 0.3223 & 0.3007 & 0.8828 & 0.3984 & 0.8655 & 0.3221 & 0.3009 \\
\hline lct017-25 & 0.8911 & 0.4016 & 0.8725 & 0.3218 & 0.3001 & 0.8846 & 0.3983 & 0.8667 & 0.3216 & 0.3003 \\
\hline $1 \operatorname{ct} 017-28$ & 0.9100 & 0.4147 & 0.8874 & 0.3331 & 0.3110 & 0.9032 & 0.4113 & 0.8810 & 0.3326 & 0.3106 \\
\hline lct017-29 & 0.9058 & 0.4116 & 0.8838 & 0.3303 & 0.3082 & 0.8992 & 0.4083 & 0.8776 & 0.3298 & 0.3080 \\
\hline lct26c3 & 0.8564 & 0.4068 & 0.8810 & 0.3402 & 0.3247 & 0.8484 & 0.4026 & 0.8730 & 0.3393 & 0.3241 \\
\hline lct $42 \mathrm{c} 1$ & 0.9222 & 0.4222 & 0.9047 & 0.3405 & 0.3185 & 0.9184 & 0.4205 & 0.9015 & 0.3416 & 0.3200 \\
\hline $1 c t 42 c 2$ & 0.9257 & 0.4219 & 0.9079 & 0.3400 & 0.3179 & 0.9206 & 0.4195 & 0.9033 & 0.3404 & 0.3186 \\
\hline $1 \mathrm{ct} 42 \mathrm{c} 3$ & 0.9288 & 0.4234 & 0.9111 & 0.3413 & 0.3193 & 0.9235 & 0.4209 & 0.9063 & 0.3416 & 0.3198 \\
\hline lct $42 \mathrm{c} 4$ & 0.9268 & 0.4226 & 0.9090 & 0.3406 & 0.3186 & 0.9215 & 0.4201 & 0.9042 & 0.3409 & 0.3191 \\
\hline lct $42 \mathrm{c} 5$ & 0.9257 & 0.4217 & 0.9079 & 0.3398 & 0.3177 & 0.9205 & 0.4192 & 0.9032 & 0.3401 & 0.3183 \\
\hline lct $42 \mathrm{c} 6$ & 0.9140 & 0.4157 & 0.8961 & 0.3345 & 0.3126 & 0.9086 & 0.4131 & 0.8913 & 0.3348 & 0.3132 \\
\hline lct $42 \mathrm{c} 7$ & 0.9226 & 0.4197 & 0.9046 & 0.3379 & 0.3159 & 0.9173 & 0.4171 & 0.8998 & 0.3382 & 0.3164 \\
\hline
\end{tabular}

Note: Cell shading identifies critical experiments applicable to bias and bias uncertainty determination.

${ }^{a}$ TSUNAMI-IP and TSUNAMI-3D input and output files for the applications and the experiments are included in the DVD attachment, paths: DVD/ip, DVD/apps/44bwr/sens, and DVD/exps/leu/sens, respectively. 
Table B-10. Integral index $c_{k}$ for nominal 21-PWR waste packages and Crystal River CRCs

\begin{tabular}{|c|c|c|c|c|c|c|c|}
\hline $\begin{array}{c}\begin{array}{c}\text { Initial } \\
\text { enrichment } \\
\left(\mathbf{w t} \%{ }^{235} \mathrm{U}\right)\end{array} \\
\end{array}$ & 2 & 3 & 3 & 3.5 & 4 & 4.5 & 5 \\
\hline $\begin{array}{c}\text { Burnup } \\
(\text { GWd/MTU) }\end{array}$ & 0 & $\mathbf{0}$ & 15 & 25 & 30 & 35 & 40 \\
\hline \multirow{2}{*}{ Filename $^{a}$} & tb2-0 & tb3-0 & tb15 & tb25 & tb30 & tb35 & tb40 \\
\hline & $\mathbf{c}_{\mathrm{k}}$ & $\mathbf{c}_{\mathrm{k}}$ & $\mathbf{c}_{\mathrm{k}}$ & $\mathbf{c}_{\mathrm{k}}$ & $\mathbf{c}_{\mathrm{k}}$ & $\mathbf{c}_{\mathrm{k}}$ & $\mathbf{c}_{\mathrm{k}}$ \\
\hline cr1r238 & 0.9587 & 0.9591 & 0.5854 & 0.5145 & 0.5058 & 0.4297 & 0.4938 \\
\hline cr2r238 & 0.6157 & 0.6042 & 0.9734 & 0.9650 & 0.9622 & 0.9494 & 0.9555 \\
\hline cr3r238 & 0.5338 & 0.5179 & 0.9740 & 0.9754 & 0.9733 & 0.9706 & 0.9673 \\
\hline cr4r238 & 0.6385 & 0.6304 & 0.9714 & 0.9608 & 0.9586 & 0.9428 & 0.9528 \\
\hline cr5r238 & 0.6807 & 0.6731 & 0.9614 & 0.9453 & 0.9426 & 0.9222 & 0.9361 \\
\hline cr6r238 & 0.5732 & 0.5611 & 0.9751 & 0.9725 & 0.9707 & 0.9634 & 0.9652 \\
\hline cr7r238 & 0.5338 & 0.5202 & 0.9705 & 0.9722 & 0.9708 & 0.9682 & 0.9658 \\
\hline cr8r238 & 0.7727 & 0.7665 & 0.9287 & 0.9004 & 0.8963 & 0.8634 & 0.8884 \\
\hline cr9r238 & 0.5393 & 0.5261 & 0.9702 & 0.9712 & 0.9697 & 0.9668 & 0.9646 \\
\hline cr10r238 & 0.5331 & 0.5198 & 0.9680 & 0.9696 & 0.9682 & 0.9656 & 0.9632 \\
\hline cr11r238 & 0.7979 & 0.7991 & 0.9053 & 0.8727 & 0.8692 & 0.8308 & 0.8624 \\
\hline cr12r238 & 0.4839 & 0.4708 & 0.9657 & 0.9732 & 0.9728 & 0.9772 & 0.9692 \\
\hline cr13r238 & 0.7439 & 0.7469 & 0.9318 & 0.9077 & 0.9057 & 0.8754 & 0.9010 \\
\hline cr14r238 & 0.6272 & 0.6253 & 0.9636 & 0.9546 & 0.9538 & 0.9390 & 0.9504 \\
\hline cr15r238 & 0.4711 & 0.4593 & 0.9635 & 0.9731 & 0.9733 & 0.9790 & 0.9709 \\
\hline cr16r238 & 0.7894 & 0.8006 & 0.8906 & 0.8589 & 0.8571 & 0.8175 & 0.8535 \\
\hline cr17r238 & 0.5650 & 0.5629 & 0.9682 & 0.9668 & 0.9672 & 0.9599 & 0.9652 \\
\hline cr18r238 & 0.5418 & 0.5387 & 0.9656 & 0.9669 & 0.9675 & 0.9632 & 0.9658 \\
\hline cr19r238 & 0.5376 & 0.5336 & 0.9684 & 0.9704 & 0.9710 & 0.9673 & 0.9692 \\
\hline cr20r238 & 0.4865 & 0.4779 & 0.9643 & 0.9722 & 0.9728 & 0.9762 & 0.9710 \\
\hline cr21r238 & 0.4857 & 0.4770 & 0.9650 & 0.9732 & 0.9738 & 0.9773 & 0.9721 \\
\hline cr22r238 & 0.7656 & 0.7781 & 0.8933 & 0.8645 & 0.8636 & 0.8272 & 0.8610 \\
\hline cr23r238 & 0.6492 & 0.6553 & 0.9480 & 0.9356 & 0.9359 & 0.9170 & 0.9344 \\
\hline cr24r238 & 0.6257 & 0.6303 & 0.9562 & 0.9472 & 0.9476 & 0.9316 & 0.9463 \\
\hline cr25r238 & 0.4951 & 0.4903 & 0.9594 & 0.9660 & 0.9672 & 0.9687 & 0.9664 \\
\hline cr26r238 & 0.4954 & 0.4908 & 0.9583 & 0.9648 & 0.9660 & 0.9673 & 0.9652 \\
\hline cr27r238 & 0.4636 & 0.4557 & 0.9568 & 0.9672 & 0.9684 & 0.9745 & 0.9676 \\
\hline cr28r238 & 0.7611 & 0.7747 & 0.8937 & 0.8655 & 0.8648 & 0.8285 & 0.8627 \\
\hline cr29r238 & 0.6093 & 0.6129 & 0.9589 & 0.9519 & 0.9525 & 0.9389 & 0.9513 \\
\hline cr30r238 & 0.5614 & 0.5621 & 0.9622 & 0.9610 & 0.9621 & 0.9552 & 0.9612 \\
\hline cr31r238 & 0.4956 & 0.4909 & 0.9614 & 0.9680 & 0.9692 & 0.9712 & 0.9684 \\
\hline cr32r238 & 0.7665 & 0.7829 & 0.8764 & 0.8468 & 0.8463 & 0.8081 & 0.8446 \\
\hline cr33r238 & 0.4676 & 0.4609 & 0.9581 & 0.9685 & 0.9699 & 0.9748 & 0.9696 \\
\hline
\end{tabular}

Note: Cell shading identifies critical experiments applicable to bias and bias uncertainty determination.

${ }^{a}$ TSUNAMI-IP and TSUNAMI-3D input and output files for the applications and the experiments are included in the DVD attachment, paths: DVD/ip, DVD/apps/21 pwr/sens, and DVD/exps/CRC/CrystalRiver/sens-unqualified, respectively. 
Table B-11. Integral index $c_{\mathrm{k}}$ for design-basis 21-PWR waste packages and Crystal River CRCs

\begin{tabular}{|c|c|c|c|c|c|c|c|}
\hline $\begin{array}{c}\text { Initial } \\
\text { enrichment } \\
\left(w t \%{ }^{235} U\right)\end{array}$ & 2 & 3 & 3 & 3.5 & 4 & 4.5 & 5 \\
\hline $\begin{array}{c}\text { Burnup } \\
\text { (GWd/MTU) }\end{array}$ & $\mathbf{0}$ & $\mathbf{0}$ & 15 & 25 & 30 & 35 & 40 \\
\hline Filename $^{a}$ & $\begin{array}{c}\mathrm{tt} 2-0 \\
\mathrm{c}_{\mathrm{k}}\end{array}$ & $\begin{array}{c}\mathrm{tt} 3-0 \\
\mathbf{c}_{\mathrm{k}}\end{array}$ & $\begin{array}{c}\mathrm{tt} 15 \\
c_{k}\end{array}$ & $\begin{array}{c}\mathrm{tt} 25 \\
\mathrm{c}_{\mathrm{k}}\end{array}$ & $\begin{array}{c}\mathrm{tt30} \\
\mathbf{c}_{\mathrm{k}}\end{array}$ & $\begin{array}{c}\mathrm{tt} 35 \\
\mathrm{c}_{\mathrm{k}}\end{array}$ & $\begin{array}{c}\mathrm{tt} 40 \\
\mathrm{c}_{\mathrm{k}}\end{array}$ \\
\hline cr1r238 & 0.9566 & 0.9593 & 0.5753 & 0.5183 & 0.5058 & 0.4862 & 0.4889 \\
\hline cr2r238 & 0.6144 & 0.6040 & 0.9734 & 0.9647 & 0.9613 & 0.9567 & 0.9549 \\
\hline cr3r238 & 0.5327 & 0.5175 & 0.9753 & 0.9745 & 0.9725 & 0.9702 & 0.9674 \\
\hline cr4r238 & 0.6371 & 0.6301 & 0.9708 & 0.9607 & 0.9577 & 0.9529 & 0.9519 \\
\hline cr5r238 & 0.6792 & 0.6732 & 0.9602 & 0.9455 & 0.9416 & 0.9355 & 0.9350 \\
\hline cr6r238 & 0.5720 & 0.5607 & 0.9757 & 0.9719 & 0.9697 & 0.9668 & 0.9650 \\
\hline cr7r238 & 0.5326 & 0.5198 & 0.9717 & 0.9714 & 0.9699 & 0.9681 & 0.9659 \\
\hline cr8r238 & 0.7711 & 0.7666 & 0.9256 & 0.9014 & 0.8955 & 0.8863 & 0.8864 \\
\hline cr9r238 & 0.5381 & 0.5259 & 0.9715 & 0.9703 & 0.9687 & 0.9668 & 0.9647 \\
\hline cr10r238 & 0.5320 & 0.5194 & 0.9693 & 0.9687 & 0.9672 & 0.9654 & 0.9633 \\
\hline cr11r238 & 0.7961 & 0.7991 & 0.9013 & 0.8740 & 0.8683 & 0.8585 & 0.8599 \\
\hline cr12r238 & 0.4829 & 0.4707 & 0.9680 & 0.9720 & 0.9718 & 0.9718 & 0.9698 \\
\hline cr13r238 & 0.7422 & 0.7468 & 0.9290 & 0.9084 & 0.9047 & 0.8974 & 0.8990 \\
\hline cr14r238 & 0.6258 & 0.6250 & 0.9630 & 0.9544 & 0.9528 & 0.9492 & 0.9494 \\
\hline cr15r238 & 0.4700 & 0.4589 & 0.9658 & 0.9718 & 0.9723 & 0.9731 & 0.9714 \\
\hline cr16r238 & 0.7875 & 0.8003 & 0.8862 & 0.8601 & 0.8561 & 0.8475 & 0.8506 \\
\hline cr17r238 & 0.5637 & 0.5625 & 0.9686 & 0.9663 & 0.9661 & 0.9646 & 0.9647 \\
\hline cr18r238 & 0.5405 & 0.5384 & 0.9665 & 0.9661 & 0.9664 & 0.9656 & 0.9655 \\
\hline cr19r238 & 0.5363 & 0.5332 & 0.9694 & 0.9696 & 0.9699 & 0.9692 & 0.9690 \\
\hline cr20r238 & 0.4854 & 0.4775 & 0.9663 & 0.9711 & 0.9718 & 0.9725 & 0.9713 \\
\hline $\mathrm{cr} 21 \mathrm{r} 238$ & 0.4846 & 0.4766 & 0.9669 & 0.9720 & 0.9728 & 0.9735 & 0.9724 \\
\hline cr22r238 & 0.7637 & 0.7781 & 0.8895 & 0.8656 & 0.8625 & 0.8549 & 0.8583 \\
\hline cr23r238 & 0.6476 & 0.6553 & 0.9468 & 0.9357 & 0.9348 & 0.9311 & 0.9330 \\
\hline cr24r238 & 0.6242 & 0.6301 & 0.9554 & 0.9471 & 0.9465 & 0.9435 & 0.9450 \\
\hline cr25r238 & 0.4939 & 0.4899 & 0.9610 & 0.9650 & 0.9661 & 0.9668 & 0.9665 \\
\hline cr26r238 & 0.4943 & 0.4904 & 0.9599 & 0.9638 & 0.9649 & 0.9656 & 0.9653 \\
\hline cr27r238 & 0.4625 & 0.4554 & 0.9591 & 0.9659 & 0.9673 & 0.9689 & 0.9680 \\
\hline cr28r238 & 0.7592 & 0.7746 & 0.8898 & 0.8666 & 0.8637 & 0.8564 & 0.8600 \\
\hline cr29r238 & 0.6078 & 0.6127 & 0.9584 & 0.9517 & 0.9514 & 0.9489 & 0.9503 \\
\hline cr30r238 & 0.5600 & 0.5620 & 0.9628 & 0.9605 & 0.9609 & 0.9599 & 0.9607 \\
\hline cr31r238 & 0.4944 & 0.4907 & 0.9632 & 0.9669 & 0.9681 & 0.9688 & 0.9686 \\
\hline cr32r238 & 0.7645 & 0.7826 & 0.8721 & 0.8479 & 0.8451 & 0.8376 & 0.8417 \\
\hline cr33r238 & 0.4664 & 0.4603 & 0.9600 & 0.9671 & 0.9689 & 0.9705 & 0.9699 \\
\hline
\end{tabular}

Note: Cell shading identifies critical experiments applicable to bias and bias uncertainty determination.

${ }^{a}$ TSUNAMI-IP and TSUNAMI-3D input and output files for the applications and the experiments are included in the DVD attachment, paths: DVD/ip, DVD/apps/21 pwr/sens, and DVD/exps/CRC/CrystalRiver/sens-unqualified, respectively. 
Table B-12. Integral index $c_{\mathrm{k}}$ for 44-BWR waste packages and Crystal River CRCs

\begin{tabular}{|c|c|c|c|c|c|c|c|c|c|c|}
\hline & \multicolumn{5}{|c|}{ Nominal configurations } & \multicolumn{5}{|c|}{ Design-basis configurations } \\
\hline $\begin{array}{c}\text { Initial } \\
\text { enrichment } \\
\left(w t \%{ }^{235} U\right)\end{array}$ & 3 & 3 & 4 & 4 & 5 & 3 & 3 & 4 & 4 & 5 \\
\hline $\begin{array}{c}\text { Burnup } \\
\text { (GWd/MTU) }\end{array}$ & $\mathbf{0}$ & 10 & $\mathbf{0}$ & 20 & 30 & $\mathbf{0}$ & 10 & $\mathbf{0}$ & 20 & 30 \\
\hline Filenamea & tb3-0 & tb3-10 & tb4-0 & tb4-20 & tb5-30 & tt3-0 & tt3-10 & tt4-0 & tt4-20 & tt5-30 \\
\hline 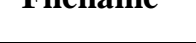 & $c_{k}$ & $\mathbf{c}_{\mathrm{k}}$ & $\mathbf{c}_{\mathrm{k}}$ & $\mathbf{c}_{\mathrm{k}}$ & $\mathbf{c}_{\mathrm{k}}$ & $\mathbf{c}_{\mathrm{k}}$ & $\mathbf{c}_{\mathrm{k}}$ & $\mathbf{c}_{\mathrm{k}}$ & $\mathbf{c}_{\mathrm{k}}$ & $\mathbf{c}_{\mathrm{k}}$ \\
\hline cr1r238 & 0.9517 & 0.4417 & 0.9412 & 0.3621 & 0.3420 & 0.9457 & 0.4395 & 0.9348 & 0.3613 & 0.3404 \\
\hline cr2r238 & 0.5953 & 0.9447 & 0.5798 & 0.9209 & 0.9120 & 0.5914 & 0.9427 & 0.5756 & 0.9196 & 0.9101 \\
\hline cr3r238 & 0.5077 & 0.9598 & 0.4897 & 0.9451 & 0.9383 & 0.5044 & 0.9580 & 0.4862 & 0.9440 & 0.9367 \\
\hline cr4r238 & 0.6224 & 0.9383 & 0.6092 & 0.9127 & 0.9039 & 0.6182 & 0.9362 & 0.6047 & 0.9113 & 0.9019 \\
\hline cr5r238 & 0.6663 & 0.9191 & 0.6533 & 0.8885 & 0.8787 & 0.6618 & 0.9170 & 0.6485 & 0.8871 & 0.8766 \\
\hline cr6r238 & 0.5518 & 0.9542 & 0.5363 & 0.9360 & 0.9287 & 0.5482 & 0.9523 & 0.5323 & 0.9347 & 0.9270 \\
\hline cr7r238 & 0.5106 & 0.9565 & 0.4944 & 0.9424 & 0.9362 & 0.5072 & 0.9546 & 0.4907 & 0.9412 & 0.9346 \\
\hline cr8r238 & 0.7591 & 0.8624 & 0.7462 & 0.8200 & 0.8076 & 0.7541 & 0.8602 & 0.7408 & 0.8186 & 0.8055 \\
\hline cr9r238 & 0.5173 & 0.9561 & 0.5016 & 0.9415 & 0.9352 & 0.5139 & 0.9542 & 0.4979 & 0.9402 & 0.9334 \\
\hline cr10r238 & 0.5103 & 0.9543 & 0.4944 & 0.9402 & 0.9341 & 0.5070 & 0.9524 & 0.4907 & 0.9390 & 0.9324 \\
\hline $\mathrm{cr} 11 \mathrm{r} 238$ & 0.7935 & 0.8336 & 0.7860 & 0.7879 & 0.7752 & 0.7879 & 0.8312 & 0.7800 & 0.7864 & 0.7728 \\
\hline cr12r238 & 0.4626 & 0.9623 & 0.4476 & 0.9544 & 0.9501 & 0.4595 & 0.9606 & 0.4443 & 0.9531 & 0.9484 \\
\hline cr13r238 & 0.7417 & 0.8749 & 0.7361 & 0.8373 & 0.8269 & 0.7364 & 0.8724 & 0.7303 & 0.8357 & 0.8245 \\
\hline cr14r238 & 0.6189 & 0.9339 & 0.6107 & 0.9106 & 0.9032 & 0.6144 & 0.9317 & 0.6059 & 0.9091 & 0.9011 \\
\hline $\operatorname{cr} 15 \mathrm{r} 238$ & 0.4509 & 0.9623 & 0.4369 & 0.9564 & 0.9529 & 0.4478 & 0.9605 & 0.4335 & 0.9551 & 0.9513 \\
\hline cr16r238 & 0.7969 & 0.8219 & 0.7970 & 0.7779 & 0.7666 & 0.7908 & 0.8192 & 0.7906 & 0.7762 & 0.7640 \\
\hline cr17r238 & 0.5566 & 0.9522 & 0.5489 & 0.9365 & 0.9311 & 0.5525 & 0.9500 & 0.5444 & 0.9349 & 0.9290 \\
\hline cr18r238 & 0.5325 & 0.9541 & 0.5243 & 0.9410 & 0.9363 & 0.5285 & 0.9519 & 0.5201 & 0.9394 & 0.9342 \\
\hline cr19r238 & 0.5269 & 0.9574 & 0.5181 & 0.9448 & 0.9401 & 0.5231 & 0.9552 & 0.5139 & 0.9433 & 0.9381 \\
\hline cr20r238 & 0.4702 & 0.9612 & 0.4584 & 0.9540 & 0.9504 & 0.4668 & 0.9592 & 0.4548 & 0.9526 & 0.9486 \\
\hline cr21r238 & 0.4690 & 0.9618 & 0.4571 & 0.9548 & 0.9514 & 0.4657 & 0.9599 & 0.4535 & 0.9534 & 0.9496 \\
\hline cr22r238 & 0.7763 & 0.8318 & 0.7782 & 0.7911 & 0.7808 & 0.7703 & 0.8290 & 0.7717 & 0.7892 & 0.7780 \\
\hline cr23r238 & 0.6524 & 0.9163 & 0.6507 & 0.8911 & 0.8840 & 0.6474 & 0.9138 & 0.6452 & 0.8892 & 0.8814 \\
\hline cr24r238 & 0.6262 & 0.9293 & 0.6233 & 0.9069 & 0.9003 & 0.6214 & 0.9268 & 0.6181 & 0.9051 & 0.8979 \\
\hline cr25r238 & 0.4840 & 0.9562 & 0.4750 & 0.9484 & 0.9451 & 0.4804 & 0.9541 & 0.4711 & 0.9469 & 0.9431 \\
\hline cr26r238 & 0.4843 & 0.9547 & 0.4755 & 0.9468 & 0.9435 & 0.4807 & 0.9526 & 0.4716 & 0.9453 & 0.9415 \\
\hline cr27r238 & 0.4489 & 0.9584 & 0.4380 & 0.9540 & 0.9515 & 0.4456 & 0.9564 & 0.4345 & 0.9525 & 0.9497 \\
\hline cr28r238 & 0.7728 & 0.8333 & 0.7754 & 0.7933 & 0.7832 & 0.7667 & 0.8305 & 0.7689 & 0.7913 & 0.7805 \\
\hline cr29r238 & 0.6088 & 0.9354 & 0.6053 & 0.9150 & 0.9088 & 0.6041 & 0.9330 & 0.6003 & 0.9132 & 0.9065 \\
\hline cr30r238 & 0.5579 & 0.9486 & 0.5528 & 0.9338 & 0.9291 & 0.5537 & 0.9463 & 0.5482 & 0.9321 & 0.9267 \\
\hline cr31r238 & 0.4852 & 0.9588 & 0.4766 & 0.9512 & 0.9480 & 0.4817 & 0.9568 & 0.4727 & 0.9497 & 0.9459 \\
\hline cr32r238 & 0.7812 & 0.8134 & 0.7859 & 0.7723 & 0.7622 & 0.7749 & 0.8105 & 0.7791 & 0.7703 & 0.7594 \\
\hline cr33r238 & 0.4533 & 0.9583 & 0.4430 & 0.9537 & 0.9513 & 0.4498 & 0.9562 & 0.4392 & 0.9522 & 0.9495 \\
\hline
\end{tabular}

Note: Cell shading identifies critical experiments applicable to bias and bias uncertainty determination.

${ }^{a}$ TSUNAMI-IP and TSUNAMI-3D input and output files for the applications and the experiments are included in the DVD attachment, paths: DVD/ip, DVD/apps/44bwr/sens, and DVD/exps/CRC/CrystalRiver/sens-unqualified, respectively. 
APPENDIX C: Direct Perturbation Calculations 

This appendix describes the direct perturbation method used to verify that the TSUNAMI-3D calculated sensitivity coefficient values are consistent with the sensitivity coefficients that MCNP would estimate. Sensitivity coefficients from MCNP direct perturbation calculations were obtained for nuclides/elements for which $k_{\text {eff }}$ exhibits significant sensitivities, such as $\mathrm{H},{ }^{10} \mathrm{~B},{ }^{235} \mathrm{U},{ }^{238} \mathrm{U},{ }^{239} \mathrm{Pu}$, and ${ }^{149} \mathrm{Sm}$. A comparison of direct perturbation and TSUNAMI-3D sensitivity coefficient calculations is presented in Table C-1. Note that the sensitivity coefficient estimates from the MCNP direct perturbation calculations have larger uncertainties than the TSUNAMI-3D sensitivity coefficients, although $k_{\text {eff }}$ estimate from each individual MCNP calculation had a very small standard deviation (0.00012). The two methods are in good agreement since the MCNP direct perturbation results differ from the TSUNAMI-3D results by less than $\pm 10 \%$ for the majority of the calculations, with the rest of the direct perturbation calculations being within $\pm 20 \%$ of the TSUNAMI-3D results.

\section{DIRECT PERTURBATION SENSITIVITY COEFFICIENTS}

The direct perturbation method is used to assess the quality of the sensitivity coefficients obtained in a TSUNAMI-3D calculation that could be affected by the quality of the neutron fluxes from forward and adjoint Monte Carlo calculations with KENO V.a. Factors that determine the quality of neutron flux estimates are related to the number and quality of sample neutron tracks or to the size of the unit volumes used in a track-length estimation of the flux.

The macroscopic cross section of a nuclide-reaction pair can be perturbed by changing either the nuclide atom density or the microscopic cross section for the neutron reaction with the nuclide. The direct perturbation method employs variations of nuclide atom density that result in small $k_{\text {eff }}$ variations consistent with the linear-perturbation approximation. Applications of this method require $k_{\text {eff }}$ results for the nominal system and for the perturbed system, with the concentration of the nuclide of interest increased or decreased by the same percentage. The direct total perturbation sensitivity coefficient of $k_{\text {eff }}$ to some input quantity is determined as

$$
S_{k}=\frac{\alpha}{k} \times \frac{d k}{d \alpha}=\frac{\alpha}{k} \times \frac{k_{\alpha^{+}}-k_{\alpha^{-}}}{\alpha^{+}-\alpha^{-}}
$$

where $\alpha^{+}$and $\alpha^{-}$represent the increased and decreased values of the input quantity, $\alpha$, respectively, and $k_{\alpha^{+}}$and $k_{\alpha^{-}}$represent the corresponding values of $k_{\text {eff. }}$ The standard deviation of a direct perturbation sensitivity coefficient is determined as

$$
\sigma_{S}=\left(\left(\frac{\left(\sigma_{k^{+}}^{2}+\sigma_{k^{-}}^{2}\right)}{\left(k^{+}-k^{-}\right)^{2}}+\frac{\sigma_{k}^{2}}{k^{2}}\right) \times\left(\frac{k^{+}-k^{-}}{k}\right)^{2}\right)^{1 / 2} \times \frac{\alpha}{\alpha^{+}-\alpha^{-}} .
$$


The direct perturbation calculations provided in the Table C-1 were performed using Microsoft Excel (see $\mathrm{DVD} / \mathrm{dp} / \mathrm{DP} . x \mathrm{ls})$. The names of the output files are described in spreadsheet DP.xls, worksheet keff results. The paths to the input and output files are indicated in the table endnotes.

Table C-1. Comparison of MCNP direct perturbation and TSUNAMI-3D sensitivity calculations

\begin{tabular}{|c|c|c|c|c|c|c|c|c|c|c|}
\hline \multicolumn{11}{|c|}{ 21-PWR waste package, initial enrichment $=3 \mathrm{wt} \%{ }^{235} \mathrm{U}$, burnup $=15 \mathrm{GWd} / \mathrm{MTU}$ : nominal configuration ${ }^{a}$} \\
\hline \multirow{2}{*}{ Nuclide } & \multirow{2}{*}{$\begin{array}{c}\text { Change } \\
(w t \%)\end{array}$} & \multicolumn{2}{|c|}{ +Change } & \multicolumn{2}{|c|}{-Change } & \multicolumn{2}{|c|}{ Direct perturbation } & \multicolumn{2}{|c|}{ TSUNAMI $^{b}$} & \multirow{2}{*}{$\begin{array}{c}\% \\
\text { Difference }^{p}\end{array}$} \\
\hline & & $\boldsymbol{k}_{\text {eff }}+$ & $\sigma+$ & $\boldsymbol{k}_{\text {eff }}{ }^{-}$ & $\sigma-$ & $\mathbf{S}_{\mathrm{k}}$ & $\sigma_{\mathrm{s}}$ & $\mathbf{S}$ & $\sigma$ & \\
\hline $\mathrm{H}$ & 1 & 0.94769 & 0.00012 & 0.94359 & 0.00012 & $2.17 \mathrm{E}-01$ & $8.98 \mathrm{E}-03$ & $2.16 \mathrm{E}-01$ & $6.02 \mathrm{E}-03$ & -0.3 \\
\hline${ }^{10} \mathrm{~B}$ & 2 & 0.94488 & 0.00013 & 0.94579 & 0.00012 & $-2.41 \mathrm{E}-02$ & $4.68 \mathrm{E}-03$ & $-2.64 \mathrm{E}-02$ & $2.90 \mathrm{E}-05$ & 9.8 \\
\hline${ }^{235} \mathrm{U}$ & 1 & 0.94623 & 0.00012 & 0.94288 & 0.00012 & $1.77 \mathrm{E}-01$ & $8.98 \mathrm{E}-03$ & $1.78 \mathrm{E}-01$ & $3.27 \mathrm{E}-04$ & 0.4 \\
\hline${ }^{238} \mathrm{U}$ & 2 & 0.94245 & 0.00012 & 0.94662 & 0.00012 & $-1.10 \mathrm{E}-01$ & $4.49 \mathrm{E}-03$ & $-1.16 \mathrm{E}-01$ & $2.73 \mathrm{E}-04$ & 5.3 \\
\hline${ }^{239} \mathrm{Pu}$ & 1 & 0.94541 & 0.00012 & 0.9436 & 0.00012 & $9.57 \mathrm{E}-02$ & $8.98 \mathrm{E}-03$ & $9.90 \mathrm{E}-02$ & $1.77 \mathrm{E}-04$ & 3.4 \\
\hline${ }^{149} \mathrm{Sm}$ & 100 & & & 0.95873 & 0.00013 & $-1.43 \mathrm{E}-02$ & $1.84 \mathrm{E}-04$ & $-1.36 \mathrm{E}-02$ & $1.23 \mathrm{E}-05$ & -4.5 \\
\hline \multicolumn{11}{|c|}{ 21-PWR waste package, initial enrichment $=5 \mathrm{wt}^{2}{ }^{235} \mathrm{U}$, burnup $=40 \mathrm{GWd} / \mathrm{MTU}$ : nominal configuration ${ }^{a}$} \\
\hline \multirow{2}{*}{ Nuclide } & \multirow{2}{*}{$\begin{array}{c}\text { Change } \\
(w t \%)\end{array}$} & \multicolumn{2}{|c|}{ +Change } & \multicolumn{2}{|c|}{-Change } & \multicolumn{2}{|c|}{ Direct perturbation } & \multicolumn{2}{|c|}{ TSUNAMI $^{b}$} & $\%$ \\
\hline & & $k_{e f f}+$ & $\sigma+$ & $\boldsymbol{k}_{\text {eff }}$ & $\sigma-$ & $\mathbf{S}_{\mathrm{k}}$ & $\sigma_{\mathrm{s}}$ & $\mathbf{S}$ & $\sigma$ & Difference $^{p}$ \\
\hline $\mathrm{H}$ & 1 & 0.93955 & 0.00013 & 0.93468 & 0.00013 & $2.60 \mathrm{E}-01$ & $9.81 \mathrm{E}-03$ & $2.50 \mathrm{E}-01$ & 8.61E-03 & -3.9 \\
\hline${ }^{10} \mathrm{~B}$ & 5 & 0.93563 & 0.00013 & 0.93814 & 0.00013 & $-2.68 \mathrm{E}-02$ & $1.96 \mathrm{E}-03$ & $-2.54 \mathrm{E}-02$ & $2.78 \mathrm{E}-05$ & -5.2 \\
\hline${ }^{235} \mathrm{U}$ & 1 & 0.93711 & 0.00013 & 0.93425 & 0.00013 & $1.53 \mathrm{E}-01$ & $9.81 \mathrm{E}-03$ & $1.48 \mathrm{E}-01$ & $2.80 \mathrm{E}-04$ & -2.8 \\
\hline${ }^{238} \mathrm{U}$ & 1 & 0.93428 & 0.00013 & 0.9358 & 0.00013 & $-8.11 \mathrm{E}-02$ & $9.81 \mathrm{E}-03$ & $-8.85 \mathrm{E}-02$ & $2.53 \mathrm{E}-04$ & 9.1 \\
\hline${ }^{239} \mathrm{Pu}$ & 1 & 0.93644 & 0.00013 & 0.93444 & 0.00013 & $1.07 \mathrm{E}-01$ & $9.81 \mathrm{E}-03$ & $9.90 \mathrm{E}-02$ & $1.94 \mathrm{E}-04$ & -7.2 \\
\hline${ }^{149} \mathrm{Sm}$ & 100 & & & 0.95127 & 0.00013 & $-1.52 \mathrm{E}-02$ & $1.84 \mathrm{E}-04$ & $-1.48 \mathrm{E}-02$ & $1.34 \mathrm{E}-05$ & -2.5 \\
\hline \multicolumn{11}{|c|}{ 21-PW } \\
\hline \multirow{2}{*}{ Nuclide } & Change & \multicolumn{2}{|c|}{ +Change } & \multicolumn{2}{|c|}{-Change } & \multicolumn{2}{|c|}{ Direct perturbation } & \multicolumn{2}{|c|}{ TSUNAMI $^{b}$} & $\%$ \\
\hline & $(w t \%)$ & $\boldsymbol{k}_{\text {eff }}+$ & $\sigma+$ & $\boldsymbol{k}_{\text {eff }}{ }^{-}$ & $\sigma-$ & $\mathbf{S}_{\mathrm{k}}$ & $\sigma_{\mathrm{s}}$ & $\mathbf{S}$ & $\sigma$ & Difference $^{p}$ \\
\hline $\mathrm{H}$ & 1 & 0.9735 & 0.00012 & 0.9698 & 0.00012 & $1.90 \mathrm{E}-01$ & $8.73 \mathrm{E}-03$ & $1.96 \mathrm{E}-01$ & $6.18 \mathrm{E}-03$ & 2.9 \\
\hline${ }^{10} \mathrm{~B}$ & 5 & 0.97067 & 0.00012 & 0.97322 & 0.00012 & $-2.62 \mathrm{E}-02$ & $1.75 \mathrm{E}-03$ & $-2.61 \mathrm{E}-02$ & $3.38 \mathrm{E}-05$ & -0.5 \\
\hline${ }^{235} \mathrm{U}$ & 1 & 0.97291 & 0.00012 & 0.96917 & 0.00012 & $1.92 \mathrm{E}-01$ & $8.73 \mathrm{E}-03$ & $1.75 \mathrm{E}-01$ & $3.49 \mathrm{E}-04$ & -9.0 \\
\hline${ }^{238} \mathrm{U}$ & 1 & 0.96965 & 0.00012 & 0.97215 & 0.00012 & $-1.29 \mathrm{E}-01$ & $8.73 \mathrm{E}-03$ & $-1.19 \mathrm{E}-01$ & $2.92 \mathrm{E}-04$ & -7.3 \\
\hline${ }^{239} \mathrm{Pu}$ & 2 & 0.97282 & 0.00012 & 0.96899 & 0.00012 & $9.85 \mathrm{E}-02$ & 4.37E-03 & $1.01 \mathrm{E}-01$ & $1.91 \mathrm{E}-04$ & 2.8 \\
\hline${ }^{149} \mathrm{Sm}$ & 100 & & & 0.98506 & 0.00012 & $-1.38 \mathrm{E}-02$ & $1.70 \mathrm{E}-04$ & $-1.37 \mathrm{E}-02$ & $1.33 \mathrm{E}-05$ & -0.5 \\
\hline \multicolumn{11}{|c|}{ 21-PWR waste package, initial enrichment $=5 \mathrm{wt} \%{ }^{235} \mathrm{U}$, burnup $=40 \mathrm{GWd} / \mathrm{MTU}$ : design-basis configuration ${ }^{a}$} \\
\hline Nuclide & & $+\mathrm{Cl}$ & nge & $-\mathrm{Cl}$ & & Direct pe & urbation & TSUI & $\mathbf{A M I}^{b}$ & $\%$ \\
\hline Nucilde & $(\mathbf{w t} \%)$ & $\boldsymbol{k}_{\text {eff }}+$ & $\sigma+$ & $\boldsymbol{k}_{\text {eff }} \mathrm{f}^{-}$ & $\sigma-$ & $\mathbf{S}_{\mathbf{k}}$ & $\sigma_{\mathrm{s}}$ & $\mathbf{S}$ & $\boldsymbol{\sigma}$ & Difference $^{p}$ \\
\hline $\mathrm{H}$ & 1 & 0.96452 & 0.00013 & 0.96039 & 0.00013 & $2.15 \mathrm{E}-01$ & $9.55 \mathrm{E}-03$ & 2.33E-01 & 7.49E-03 & 8.6 \\
\hline${ }^{10} \mathrm{~B}$ & 2 & 0.96222 & 0.00013 & 0.96339 & 0.00013 & $-3.04 \mathrm{E}-02$ & $4.78 \mathrm{E}-03$ & $-2.48 \mathrm{E}-02$ & $3.12 \mathrm{E}-05$ & -18.3 \\
\hline${ }^{235} \mathrm{U}$ & 1 & 0.96243 & 0.00013 & 0.95982 & 0.00013 & $1.36 \mathrm{E}-01$ & $9.55 \mathrm{E}-03$ & $1.47 \mathrm{E}-01$ & $2.90 \mathrm{E}-04$ & 8.4 \\
\hline${ }^{238} \mathrm{U}$ & 1 & 0.96042 & 0.00013 & 0.96209 & 0.00013 & $-8.68 \mathrm{E}-02$ & $9.55 \mathrm{E}-03$ & $-9.14 \mathrm{E}-02$ & $2.62 \mathrm{E}-04$ & 5.3 \\
\hline${ }^{239} \mathrm{Pu}$ & 2 & 0.96322 & 0.00013 & 0.95923 & 0.00012 & $1.04 \mathrm{E}-01$ & $4.60 \mathrm{E}-03$ & $9.97 \mathrm{E}-02$ & $2.00 \mathrm{E}-04$ & -3.8 \\
\hline${ }^{149} \mathrm{Sm}$ & 100 & & & 0.97719 & 0.00013 & $-1.53 \mathrm{E}-02$ & $1.84 \mathrm{E}-04$ & $-1.49 \mathrm{E}-02$ & $1.38 \mathrm{E}-05$ & -2.5 \\
\hline & 44- & VR waste & kage, initi & enrichmen & $3 \mathrm{wt} \%$ & burnup $=0$ & Wd/MTU: & ominal conf & uration $^{c}$ & \\
\hline Nuclide & & $+\mathrm{Cl}$ & & $-\mathrm{Cl}$ & & Direct pe & urbation & TSUI & $\mathrm{AMI}^{d}$ & $\%$ \\
\hline Nucilde & $(w t \%)$ & $\boldsymbol{k}_{\text {eff }}+$ & $\sigma+$ & $\boldsymbol{k}_{\text {eff }}$ & $\sigma-$ & $S_{k}$ & $\sigma_{\mathrm{s}}$ & $\mathbf{S}$ & $\sigma$ & Difference $^{p}$ \\
\hline $\mathrm{H}$ & 1 & 0.84805 & 0.00013 & 0.84456 & 0.00013 & $2.06 \mathrm{E}-01$ & $1.09 \mathrm{E}-02$ & $1.76 \mathrm{E}-01$ & $5.71 \mathrm{E}-03$ & -14.5 \\
\hline${ }^{10} \mathrm{~B}$ & 2 & 0.84547 & 0.00013 & 0.84710 & 0.00013 & $-4.82 \mathrm{E}-02$ & $5.43 \mathrm{E}-03$ & $-4.51 \mathrm{E}-02$ & $4.46 \mathrm{E}-05$ & -6.3 \\
\hline${ }^{235} \mathrm{U}$ & 1 & 0.84857 & 0.00013 & 0.84424 & 0.00013 & $2.56 \mathrm{E}-01$ & $1.09 \mathrm{E}-02$ & $2.65 \mathrm{E}-01$ & $5.14 \mathrm{E}-04$ & 3.4 \\
\hline${ }^{238} \mathrm{U}$ & 1 & 0.8455 & 0.00013 & 0.84737 & 0.00013 & $-1.10 \mathrm{E}-01$ & $1.09 \mathrm{E}-02$ & $-1.12 \mathrm{E}-01$ & $2.80 \mathrm{E}-04$ & 1.1 \\
\hline
\end{tabular}


Table C-1. Comparison of MCNP direct perturbation and TSUNAMI-3D sensitivity calculations (continued)

\begin{tabular}{|c|c|c|c|c|c|c|c|c|c|c|}
\hline \multicolumn{11}{|c|}{ 44-BWR waste package, initial enrichment $=5 \mathrm{wt} \%{ }^{235} \mathrm{U}$, burnup $=30 \mathrm{GWd} / \mathrm{MTU}$ : nominal configuration ${ }^{c}$} \\
\hline \multirow{2}{*}{ Nuclide } & \multirow{2}{*}{$\begin{array}{c}\text { Change } \\
\text { (wt\%) }\end{array}$} & \multicolumn{2}{|c|}{ +Change } & \multicolumn{2}{|c|}{-Change } & \multicolumn{2}{|c|}{ Direct perturbation } & \multicolumn{2}{|c|}{ TSUNAMI $^{d}$} & \multirow{2}{*}{$\begin{array}{c}\% \\
\text { Difference }^{p}\end{array}$} \\
\hline & & $k_{e f f}+$ & $\sigma+$ & $\boldsymbol{k}_{e f f^{-}}$ & $\sigma-$ & $S_{k}$ & $\sigma_{\mathrm{s}}$ & $\mathbf{S}$ & $\sigma$ & \\
\hline $\mathrm{H}$ & 1 & 0.83484 & 0.00013 & 0.83159 & 0.00013 & $1.95 \mathrm{E}-01$ & $1.10 \mathrm{E}-02$ & $1.83 \mathrm{E}-01$ & $4.48 \mathrm{E}-03$ & -6.3 \\
\hline${ }^{10} \mathrm{~B}$ & 5 & 0.83157 & 0.00013 & 0.83502 & 0.00013 & $-4.14 \mathrm{E}-02$ & $2.21 \mathrm{E}-03$ & $-4.31 \mathrm{E}-02$ & $4.96 \mathrm{E}-05$ & 4.1 \\
\hline${ }^{235} \mathrm{U}$ & 1 & 0.83223 & 0.00013 & 0.83049 & 0.00013 & $1.04 \mathrm{E}-01$ & $1.10 \mathrm{E}-02$ & $1.16 \mathrm{E}-01$ & $2.18 \mathrm{E}-04$ & 10.7 \\
\hline${ }^{238} \mathrm{U}$ & 4 & 0.82967 & 0.00013 & 0.83340 & 0.00013 & $-5.60 \mathrm{E}-02$ & $2.76 \mathrm{E}-03$ & $-5.96 \mathrm{E}-02$ & $2.82 \mathrm{E}-04$ & 6.5 \\
\hline${ }^{239} \mathrm{Pu}$ & 1 & 0.83268 & 0.00013 & 0.83063 & 0.00013 & $1.23 \mathrm{E}-01$ & $1.10 \mathrm{E}-02$ & $1.24 \mathrm{E}-01$ & $2.95 \mathrm{E}-04$ & 0.6 \\
\hline${ }^{149} \mathrm{Sm}$ & 100 & & & 0.86302 & 0.00014 & $-3.62 \mathrm{E}-02$ & $1.91 \mathrm{E}-04$ & $-3.44 \mathrm{E}-02$ & $3.51 \mathrm{E}-05$ & -5.1 \\
\hline \multicolumn{11}{|c|}{ 44-BWR waste package, initial enrichment $=3 \mathrm{wt} \%{ }^{235} \mathrm{U}$, burnup $=0 \mathrm{GWd} / \mathrm{MTU}$ : design-basis configuration ${ }^{c}$} \\
\hline \multirow{2}{*}{ Nuclide } & Change & \multicolumn{2}{|c|}{ +Change } & \multicolumn{2}{|c|}{-Change } & \multicolumn{2}{|c|}{ Direct perturbation } & \multicolumn{2}{|c|}{ TSUNAMI $^{d}$} & \multirow{2}{*}{$\begin{array}{c}\% \\
\text { Difference }^{p}\end{array}$} \\
\hline & $(w t \%)$ & $\boldsymbol{k}_{e f f^{+}}$ & $\sigma+$ & $k_{e f f}$ & $\sigma-$ & $\mathbf{S}_{\mathrm{k}}$ & $\sigma_{\mathrm{s}}$ & $\mathbf{S}$ & $\sigma$ & \\
\hline $\mathrm{H}$ & 1 & 0.89133 & 0.00013 & 0.88857 & 0.00013 & $1.55 \mathrm{E}-01$ & $1.03 \mathrm{E}-02$ & $1.48 \mathrm{E}-01$ & $5.58 \mathrm{E}-03$ & -4.7 \\
\hline${ }^{10} \mathrm{~B}$ & 5 & 0.88823 & 0.00013 & 0.89188 & 0.00013 & $-4.10 \mathrm{E}-02$ & 2.07E-03 & $-4.25 \mathrm{E}-02$ & $4.86 \mathrm{E}-05$ & 3.5 \\
\hline${ }^{235} \mathrm{U}$ & 1 & 0.89228 & 0.00013 & 0.88736 & 0.00013 & $2.76 \mathrm{E}-01$ & $1.03 \mathrm{E}-02$ & $2.63 \mathrm{E}-01$ & 5.03E-04 & -4.9 \\
\hline${ }^{238} \mathrm{U}$ & 2 & 0.88802 & 0.00013 & 0.89217 & 0.00013 & $-1.17 \mathrm{E}-01$ & $5.16 \mathrm{E}-03$ & $-1.16 \mathrm{E}-01$ & $2.75 \mathrm{E}-04$ & -0.6 \\
\hline \multicolumn{11}{|c|}{ 44-BWR waste package, initial enrichment $=5 \mathrm{wt} \%{ }^{235} \mathrm{U}$, burnup $=30 \mathrm{GWd} / \mathrm{MTU}$ : design-basis configuration ${ }^{c}$} \\
\hline \multirow{2}{*}{ Nuclide } & & \multicolumn{2}{|c|}{ +Change } & \multicolumn{2}{|c|}{-Change } & \multicolumn{2}{|c|}{ Direct perturbation } & \multicolumn{2}{|c|}{ TSUNAMI $^{d}$} & \multirow{2}{*}{$\begin{array}{c}\% \\
\text { Difference }^{p}\end{array}$} \\
\hline & $(\mathbf{w t} \%)$ & $\boldsymbol{k}_{\text {eff }}+$ & $\sigma+$ & $\boldsymbol{k}_{e f f^{-}}$ & $\sigma-$ & $\mathbf{S}_{\mathrm{k}}$ & $\sigma_{\mathrm{s}}$ & $\mathbf{S}$ & $\sigma$ & \\
\hline $\mathrm{H}$ & 1 & 0.8761 & 0.00013 & 0.87333 & 0.00013 & $1.58 \mathrm{E}-01$ & $1.05 \mathrm{E}-02$ & $1.60 \mathrm{E}-01$ & $4.39 \mathrm{E}-03$ & 1.0 \\
\hline${ }^{10} \mathrm{~B}$ & 5 & 0.87282 & 0.00013 & 0.8766 & 0.00013 & $-4.32 \mathrm{E}-02$ & $2.10 \mathrm{E}-03$ & $-3.97 \mathrm{E}-02$ & $5.28 \mathrm{E}-05$ & -8.1 \\
\hline${ }^{235} \mathrm{U}$ & 1 & 0.87407 & 0.00013 & 0.87211 & 0.00013 & $1.12 \mathrm{E}-01$ & $1.05 \mathrm{E}-02$ & $1.14 \mathrm{E}-01$ & $2.15 \mathrm{E}-04$ & 1.9 \\
\hline${ }^{238} \mathrm{U}$ & 2 & 0.87179 & 0.00013 & 0.87419 & 0.00013 & $-6.86 \mathrm{E}-02$ & $5.25 \mathrm{E}-03$ & $-6.29 \mathrm{E}-02$ & $2.77 \mathrm{E}-04$ & -8.3 \\
\hline${ }^{239} \mathrm{Pu}$ & 1 & 0.87393 & 0.00013 & 0.87185 & 0.00013 & 1.19E-01 & $1.05 \mathrm{E}-02$ & $1.23 \mathrm{E}-01$ & $2.93 \mathrm{E}-04$ & 3.1 \\
\hline${ }^{149} \mathrm{Sm}$ & 100 & & & 0.90649 & 0.00014 & $-3.63 \mathrm{E}-02$ & $1.91 \mathrm{E}-04$ & $-3.47 \mathrm{E}-02$ & $3.48 \mathrm{E}-05$ & -4.4 \\
\hline \multicolumn{11}{|c|}{ LEU LCEs; lct42c3 = unperturbed MCNP model $^{e}$} \\
\hline \multirow{2}{*}{ Nuclide } & Change & \multicolumn{2}{|c|}{ +Change } & $-\mathrm{Ch}$ & & Direct pe & urbation & TSUN & $\mathbf{M I}^{f}$ & \\
\hline & $(\mathrm{wt} \%)$ & $k_{e f f^{+}}$ & $\sigma+$ & $\boldsymbol{k}_{\text {eff }}$ & $\sigma-$ & $\mathbf{S}_{\mathrm{k}}$ & $\sigma_{\mathrm{s}}$ & $\mathbf{S}$ & $\sigma$ & Differenc $c^{p}$ \\
\hline $\mathrm{H}$ & 1 & 0.99661 & 0.00013 & 0.99161 & 0.00013 & $2.52 \mathrm{E}-01$ & $9.25 \mathrm{E}-03$ & $2.26 \mathrm{E}-01$ & $1.19 \mathrm{E}-01$ & -10.2 \\
\hline${ }^{235} \mathrm{U}$ & 1 & 0.99657 & 0.00013 & 0.99170 & 0.00013 & $2.45 \mathrm{E}-01$ & $9.25 \mathrm{E}-03$ & $2.48 \mathrm{E}-01$ & $7.00 \mathrm{E}-04$ & 1.1 \\
\hline${ }^{238} \mathrm{U}$ & 2 & 0.99114 & 0.00013 & 0.99681 & 0.00013 & $-1.43 \mathrm{E}-01$ & $4.62 \mathrm{E}-03$ & $-1.44 \mathrm{E}-01$ & $5.09 \mathrm{E}-04$ & 1.1 \\
\hline & & & & XX LCEs; & act08-01 = & unperturbec & MCNP ma & & & \\
\hline Nuclide & Change & $+\mathrm{C}$ & & & & Direct pe & turbation & TSUN & $\mathbf{M M I ^ { h }}$ & \\
\hline & $(\mathrm{wt} \%)$ & $\boldsymbol{k}_{e f f^{+}}$ & $\sigma+$ & $\boldsymbol{k}_{\text {eff }}$ & $\sigma-$ & $\mathbf{S}_{\mathrm{k}}$ & $\sigma_{\mathrm{s}}$ & $\mathbf{S}$ & $\sigma$ & Difference $^{p}$ \\
\hline $\mathrm{H}$ & 1 & 0.99491 & 0.00015 & 0.98964 & 0.00015 & $2.66 \mathrm{E}-01$ & $1.07 \mathrm{E}-02$ & $2.91 \mathrm{E}-01$ & $2.20 \mathrm{E}-02$ & 9.5 \\
\hline${ }^{235} \mathrm{U}$ & 2 & 0.99307 & 0.00015 & 0.99148 & 0.00015 & $4.01 \mathrm{E}-02$ & $5.34 \mathrm{E}-03$ & $3.99 \mathrm{E}-02$ & $8.67 \mathrm{E}-05$ & -0.4 \\
\hline${ }^{238} \mathrm{U}$ & 2 & 0.99047 & 0.00015 & 0.99413 & 0.00015 & $-9.22 \mathrm{E}-02$ & $5.34 \mathrm{E}-03$ & $-9.13 E-02$ & $2.92 \mathrm{E}-04$ & -1.0 \\
\hline${ }^{239} \mathrm{Pu}$ & 2 & 0.99465 & 0.00015 & 0.98986 & 0.00015 & $1.21 \mathrm{E}-01$ & $5.34 \mathrm{E}-03$ & $1.32 \mathrm{E}-01$ & $3.37 \mathrm{E}-04$ & 9.2 \\
\hline
\end{tabular}


Table C-1. Comparison of MCNP direct perturbation and TSUNAMI-3D sensitivity calculations (continued)

\begin{tabular}{|c|c|c|c|c|c|c|c|c|c|c|}
\hline \multicolumn{11}{|c|}{ HTC LCEs; htc1c01 = unperturbed MCNP model ${ }^{i}$} \\
\hline \multirow{2}{*}{ Nuclide } & \multirow{2}{*}{$\begin{array}{l}\text { Change } \\
\text { (wt\%) }\end{array}$} & \multicolumn{2}{|c|}{ +Change } & \multicolumn{2}{|c|}{-Change } & \multicolumn{2}{|c|}{ Direct perturbation } & \multicolumn{2}{|c|}{ TSUNAMI } & \multirow{2}{*}{$\begin{array}{c}\% \\
\text { Difference }\end{array}$} \\
\hline & & $\boldsymbol{k}_{\text {eff }}+$ & $\sigma+$ & $\boldsymbol{k}_{e f f^{-}}$ & $\sigma-$ & $\mathbf{S}_{\mathbf{k}}$ & $\sigma_{\mathrm{s}}$ & $\mathbf{S}$ & $\sigma$ & \\
\hline $\mathrm{H}$ & 0.5 & 0.99641 & 0.0001 & 0.99829 & 0.0001 & $-1.88 \mathrm{E}-01$ & $1.42 \mathrm{E}-02$ & $-1.65 \mathrm{E}-01$ & $5.96 \mathrm{E}-02$ & -12.5 \\
\hline${ }^{235} \mathrm{U}$ & 1 & 0.99945 & 0.0001 & 0.99538 & 0.0001 & $2.04 \mathrm{E}-01$ & 7.09E-03 & $1.96 \mathrm{E}-01$ & $5.46 \mathrm{E}+00$ & -3.9 \\
\hline${ }^{238} \mathrm{U}$ & 1 & 0.99667 & 0.0001 & 0.99824 & 0.0001 & $-7.87 \mathrm{E}-02$ & 7.09E-03 & $-8.05 \mathrm{E}-02$ & $3.31 \mathrm{E}-04$ & 2.3 \\
\hline \multicolumn{11}{|c|}{ HTC LCEs; htc2b01 = unperturbed MCNP model $^{k}$} \\
\hline \multirow{2}{*}{ Nuclide } & \multirow{2}{*}{$\begin{array}{c}\text { Change } \\
(\text { wt \%) }\end{array}$} & \multicolumn{2}{|c|}{ +Change } & \multicolumn{2}{|c|}{-Change } & \multicolumn{2}{|c|}{ Direct perturbation } & \multicolumn{2}{|c|}{ TSUNAMI } & \multirow{2}{*}{$\begin{array}{c}\% \\
\text { Difference }^{p}\end{array}$} \\
\hline & & $\boldsymbol{k}_{e f f^{+}}$ & $\sigma+$ & $\boldsymbol{k}_{\text {eff }}$ & $\sigma-$ & $\mathbf{S}_{\mathrm{k}}$ & $\sigma_{\mathrm{s}}$ & $\mathbf{S}$ & $\sigma$ & \\
\hline $\mathrm{H}$ & 1 & 0.99797 & 0.00013 & 0.99255 & 0.00013 & $2.72 \mathrm{E}-01$ & $9.24 \mathrm{E}-03$ & $2.68 \mathrm{E}-01$ & $1.12 \mathrm{E}-02$ & -1.6 \\
\hline${ }^{235} \mathrm{U}$ & 1 & 0.99627 & 0.00013 & 0.99377 & 0.00014 & $1.26 \mathrm{E}-01$ & $9.60 \mathrm{E}-03$ & $1.17 \mathrm{E}-01$ & $1.99 \mathrm{E}-05$ & -6.9 \\
\hline${ }^{238} \mathrm{U}$ & 2 & 0.99335 & 0.00013 & 0.99720 & 0.00014 & $-9.67 \mathrm{E}-02$ & $4.80 \mathrm{E}-03$ & $-1.10 \mathrm{E}-01$ & $3.01 \mathrm{E}-04$ & 13.9 \\
\hline${ }^{10} \mathrm{~B}$ & 1 & 0.99489 & 0.00013 & 0.99526 & 0.00013 & $-1.86 \mathrm{E}-02$ & $9.24 \mathrm{E}-03$ & $-1.72 \mathrm{E}-02$ & $1.99 \mathrm{E}-05$ & -7.3 \\
\hline \multicolumn{11}{|c|}{ HTC LCEs; htc2g01 = unperturbed MCNP model $^{l}$} \\
\hline \multirow{2}{*}{ Nuclide } & \multirow{2}{*}{$\begin{array}{c}\text { Change } \\
\text { (wt\%) }\end{array}$} & \multicolumn{2}{|c|}{ +Change } & \multicolumn{2}{|c|}{-Change } & \multicolumn{2}{|c|}{ Direct perturbation } & \multicolumn{2}{|c|}{ TSUNAMI ${ }^{j}$} & \multirow{2}{*}{$\begin{array}{c}\% \\
\text { Difference }^{p}\end{array}$} \\
\hline & & $\boldsymbol{k}_{\text {eff }}+$ & $\sigma+$ & $\boldsymbol{k}_{e f f^{-}}$ & $\sigma-$ & $\mathbf{S}_{\mathrm{k}}$ & $\sigma_{\mathrm{s}}$ & $\mathbf{S}$ & $\sigma$ & \\
\hline $\mathrm{H}$ & 1 & 0.99770 & 0.00013 & 0.99228 & 0.00013 & $2.72 \mathrm{E}-01$ & $9.24 \mathrm{E}-03$ & $2.63 \mathrm{E}-01$ & $8.73 \mathrm{E}-03$ & -3.5 \\
\hline${ }^{235} \mathrm{U}$ & 2 & 0.99760 & 0.00014 & 0.99219 & 0.00014 & $1.36 \mathrm{E}-01$ & $4.98 \mathrm{E}-03$ & $1.21 \mathrm{E}-01$ & $2.39 \mathrm{E}-04$ & -11.0 \\
\hline${ }^{238} \mathrm{U}$ & 1 & 0.99384 & 0.00014 & 0.99577 & 0.00014 & $-9.70 \mathrm{E}-02$ & $9.95 \mathrm{E}-03$ & $-1.09 \mathrm{E}-01$ & $2.96 \mathrm{E}-04$ & 12.5 \\
\hline${ }^{157} \mathrm{Gd}$ & 5 & 0.99366 & 0.00013 & 0.99564 & 0.00014 & $-1.99 \mathrm{E}-02$ & $1.92 \mathrm{E}-03$ & $-2.14 \mathrm{E}-02$ & $2.54 \mathrm{E}-04$ & 7.7 \\
\hline \multicolumn{11}{|c|}{ HTC LCEs; htc301 = unperturbed model $^{m}$} \\
\hline \multirow{2}{*}{ Nuclide } & \multirow{2}{*}{$\begin{array}{c}\text { Change } \\
(\text { wt \%) }\end{array}$} & \multicolumn{2}{|c|}{ +Change } & $-\mathrm{Cl}$ & & Direct pe & turbation & TSUI & AMi & \\
\hline & & $\boldsymbol{k}_{e f f^{+}}$ & $\sigma+$ & $\boldsymbol{k}_{\text {eff- }}$ & $\sigma-$ & $\mathbf{S}_{\mathrm{k}}$ & $\sigma_{\mathrm{s}}$ & $\mathbf{S}$ & $\sigma$ & Difference $^{p}$ \\
\hline $\mathrm{H}$ & 1 & 0.99716 & 0.00013 & 0.99426 & 0.00013 & $1.46 \mathrm{E}-01$ & $9.23 \mathrm{E}-03$ & $1.50 \mathrm{E}-01$ & $1.15 \mathrm{E}-02$ & 3.1 \\
\hline${ }^{235} \mathrm{U}$ & 1 & 0.99694 & 0.00013 & 0.99436 & 0.00013 & $1.30 \mathrm{E}-01$ & $9.23 \mathrm{E}-03$ & $1.49 \mathrm{E}-01$ & $2.83 \mathrm{E}-04$ & 15.2 \\
\hline${ }^{238} \mathrm{U}$ & 1 & 0.99476 & 0.00013 & 0.99694 & 0.00013 & $-1.10 \mathrm{E}-01$ & $9.23 \mathrm{E}-03$ & $-9.54 \mathrm{E}-02$ & $2.55 \mathrm{E}-04$ & -12.9 \\
\hline & & & & HTC L & s; htc4s0 & = unpertu & ed model $^{n}$ & & & \\
\hline Nuclide & & $+\mathrm{Cl}$ & inge & $-\mathrm{Cl}$ & & Direct pe & turbation & TSUI & AMI & \\
\hline Nuctac & $(\mathrm{wt} \%)$ & $\boldsymbol{k}_{e f t^{+}}$ & $\sigma+$ & $\boldsymbol{k}_{e f f^{-}}$ & $\sigma-$ & $\mathbf{S}_{\mathrm{k}}$ & $\sigma_{\mathrm{s}}$ & $\mathbf{S}$ & $\sigma$ & Difference $^{p}$ \\
\hline $\mathrm{H}$ & 1 & 1.00126 & 0.00012 & 0.99809 & 0.00012 & $1.59 \mathrm{E}-01$ & 8.49E-03 & $1.58 \mathrm{E}-01$ & 8.49E-03 & -0.2 \\
\hline${ }^{235} \mathrm{U}$ & 1 & 1.00116 & 0.00013 & 0.99814 & 0.00012 & $1.51 \mathrm{E}-01$ & $8.85 \mathrm{E}-03$ & $1.54 \mathrm{E}-01$ & $2.29 \mathrm{E}-04$ & 1.9 \\
\hline${ }^{238} \mathrm{U}$ & 1 & 0.99889 & 0.00012 & 1.00077 & 0.00012 & $-9.40 \mathrm{E}-02$ & $8.49 \mathrm{E}-03$ & $-9.58 \mathrm{E}-02$ & $2.55 \mathrm{E}-04$ & 1.9 \\
\hline
\end{tabular}


Table C-1. Comparison of MCNP direct perturbation and TSUNAMI-3D sensitivity calculations (continued)

\begin{tabular}{|c|c|c|c|c|c|c|c|c|c|c|}
\hline \multirow{3}{*}{ Nuclide } & \multicolumn{10}{|c|}{ HTC LCEs; htc4101 = unperturbed model ${ }^{\circ}$} \\
\hline & \multirow{2}{*}{$\begin{array}{c}\text { Change } \\
(w t \%)\end{array}$} & \multicolumn{2}{|c|}{ +Change } & \multicolumn{2}{|c|}{-Change } & \multicolumn{2}{|c|}{ Direct perturbation } & \multicolumn{2}{|c|}{ TSUNAMI ${ }^{j}$} & \multirow{2}{*}{$\begin{array}{c}\% \\
\text { Difference }^{p}\end{array}$} \\
\hline & & $\boldsymbol{k}_{e f f}+$ & $\sigma+$ & $\boldsymbol{k}_{\text {eff }}$ & $\sigma-$ & $S_{k}$ & $\sigma_{\mathrm{s}}$ & $\mathbf{S}$ & $\sigma$ & \\
\hline $\mathrm{H}$ & 1 & 1.00328 & 0.00012 & 1.00011 & 0.00012 & $1.58 \mathrm{E}-01$ & $8.47 \mathrm{E}-03$ & $1.60 \mathrm{E}-01$ & $8.49 \mathrm{E}-03$ & 0.9 \\
\hline${ }^{235} \mathrm{U}$ & 1 & 1.0032 & 0.00012 & 1.00035 & 0.00012 & $1.42 \mathrm{E}-01$ & 8.47E-03 & $1.54 \mathrm{E}-01$ & $2.25 \mathrm{E}-04$ & 8.0 \\
\hline${ }^{238} \mathrm{U}$ & 1 & 1.00074 & 0.00013 & 1.00248 & 0.00012 & $-8.68 \mathrm{E}-02$ & $8.83 \mathrm{E}-03$ & $-9.51 \mathrm{E}-02$ & $2.23 \mathrm{E}-04$ & 9.5 \\
\hline
\end{tabular}

The input and output files are included in the DVD attachment, paths:

${ }^{a} \mathrm{DVD} / \mathrm{dp} / 21 \mathrm{pwr}$.

${ }^{b} \mathrm{DVD} / \mathrm{apps} / 21 \mathrm{pwr} / \mathrm{sens}$.

${ }^{\mathrm{c}} \mathrm{DVD} / \mathrm{dp} / 44 \mathrm{bwr}$.

${ }^{d}$ DVD/apps/44bwr/sens.

${ }^{e} \mathrm{DVD} / \mathrm{dp} / \mathrm{leu}$.

${ }^{f} \mathrm{DVD} / \mathrm{exps} / \mathrm{leu} /$ sens.

${ }^{g} \mathrm{DVD} / \mathrm{dp} / \mathrm{mox}$.

${ }^{h} \mathrm{DVD} / \mathrm{exps} / \mathrm{mox} / \mathrm{sens}$.

${ }^{i} \mathrm{DVD} / \mathrm{dp} / \mathrm{htc} / \mathrm{htc} 1$.

${ }^{J} \mathrm{DVD} / \mathrm{exps} / \mathrm{htc} / \mathrm{sens}$.

${ }^{k} \mathrm{DVD} / \mathrm{dp} / \mathrm{htc} / \mathrm{htc} 2 / \mathrm{B}$.

${ }^{l} \mathrm{DVD} / \mathrm{dp} / \mathrm{htc} / \mathrm{htc} 2 / \mathrm{Gd}$.

${ }^{m} \mathrm{DVD} / \mathrm{dp} / \mathrm{htc} / \mathrm{htc} 3$.

${ }^{n} \mathrm{DVD} / \mathrm{dp} / \mathrm{htc} / \mathrm{htc} 4 / \mathrm{SS}$.

${ }^{o} \mathrm{DVD} / \mathrm{dp} / \mathrm{htc} / \mathrm{htc} 4 / \mathrm{Pb}$.

${ }^{p}\left(\mathrm{~S}-\mathrm{S}_{\mathrm{k}}\right) / \mathrm{S}_{\mathrm{k}} * 100$ 

APPENDIX D: Various CRC Calculations and Results

D-1 

This appendix contains various CRC calculations needed for analyses presented in this report. Changes were made to the original MCNP input files (Ref. 53) to create new input files for MCNP 5.1.40 calculations with ENDF/B-VI. A change made to the input files for one-eighth symmetry CRC models consists of replacement of the original geometry cutting plane that defines a one-eighth symmetry core model with a cutting plane that defines a one-fourth symmetry core model. Note that the modeling for a one-fourth symmetry core was already implemented in the original MCNP 4B input files for these cases. The MCNP 4C $k_{\text {eff }}$ results for one-fourth symmetry geometry and the MCNP 4B $k_{\text {eff }}$ results for the oneeighth symmetry geometry provided in Ref. 52 are almost identical, as shown in Table D-1, which indicate that the two MCNP core models are identical. Note that the MCNP 4B version was not available for these calculations and the MCNP 4C version was used instead. Also note that the results of these calculations were not used in the validation calculations; they only confirm that the modified and original MCNP core geometry representations are equivalent.

Table D-1. One-fourth core symmetry MCNP calculations

\begin{tabular}{|c|c|c|c|c|c|}
\hline & \multicolumn{3}{|c|}{ MCNP 4C $^{a}$} & Comparison calculations $^{b}$ \\
\hline $\begin{array}{c}\text { State- } \\
\text { point }\end{array}$ & $\begin{array}{c}\text { Output } \\
\text { file }\end{array}$ & $\boldsymbol{k}_{\text {eff }}$ & $\sigma$ & $\boldsymbol{k}_{\text {eff }}$ & $\sigma$ \\
\hline 1 & CR1qo & 0.9965 & 0.0005 & 0.9960 & 0.0004 \\
\hline 10 & CR10qo & 0.9968 & 0.0004 & 0.9960 & 0.0005 \\
\hline 11 & CR11qo & 0.9951 & 0.0005 & 0.9948 & 0.0005 \\
\hline 12 & CR12qo & 0.9977 & 0.0004 & 0.9981 & 0.0005 \\
\hline 13 & CR13qo & 0.9953 & 0.0005 & 0.9956 & 0.0004 \\
\hline 14 & CR14qo & 0.9958 & 0.0005 & 0.9958 & 0.0005 \\
\hline 15 & CR15qo & 0.9929 & 0.0005 & 0.9927 & 0.0004 \\
\hline 16 & CR16qo & 0.9930 & 0.0005 & 0.9932 & 0.0005 \\
\hline 17 & CR17qo & 0.9927 & 0.0004 & 0.9908 & 0.0005 \\
\hline 18 & CR18qo & 0.9918 & 0.0005 & 0.9922 & 0.0005 \\
\hline 19 & CR19qo & 0.9914 & 0.0005 & 0.9899 & 0.0005 \\
\hline 20 & CR20qo & 0.9938 & 0.0004 & 0.9932 & 0.0004 \\
\hline 21 & CR21qo & 0.9931 & 0.0004 & 0.9925 & 0.0005 \\
\hline 32 & CR32qo & 0.9903 & 0.0005 & 0.9916 & 0.0005 \\
\hline 33 & CR33qo & 0.9870 & 0.0005 & 0.9873 & 0.0005 \\
\hline
\end{tabular}

CSAS25/KENO V.a modeling was performed for Crystal River Unit 3 CRC state-points for use in TSUNAMI-3D calculations. Generally, the CSAS25 $k_{\text {eff }}$ results are in good agreement with the results described in the referenced document $( \pm 0.3 \%)$, as shown in Table D-2, indicating that the mixture compositions and geometry models are consistent between the CSAS25 and MCNP calculations. Only the results for the last two Crystal River state-points are significantly lower than the comparison MCNP calculation results. However, the impact on sensitivity coefficients is expected to be less important because these coefficients are defined in terms of relative values (see Appendix B). Note that the results of these calculations were not used directly in the validation calculations; they only confirm that the CSAS/KENO V.a and MCNP model representations (Ref. 53) are equivalent. 
Table D-2. $k_{\text {eff }}$ results for Crystal River CRC state-points

\begin{tabular}{|c|c|c|c|c|c|c|c|}
\hline \multirow{2}{*}{$\begin{array}{l}\text { State } \\
\text { point }\end{array}$} & \multirow{2}{*}{$\begin{array}{c}\text { Case } \\
\text { identifier }\end{array}$} & \multirow{2}{*}{$\begin{array}{c}\text { EALF } \\
(\mathrm{eV})\end{array}$} & \multicolumn{2}{|c|}{ CSAS25 $^{a}$} & \multicolumn{2}{|c|}{ Comparison calculations $^{b}$} & \multirow{2}{*}{$\begin{array}{c}\% \\
\text { Difference }^{c}\end{array}$} \\
\hline & & & $\boldsymbol{k}_{\text {eff }}$ & $\sigma$ & $\boldsymbol{k}_{\text {eff }}$ & $\sigma$ & \\
\hline 1 & CR3SP1 & $5.58 \mathrm{E}-01$ & 0.9938 & 0.0004 & 0.9960 & 0.0004 & 0.22 \\
\hline 2 & CR3SP2 & $6.28 \mathrm{E}-01$ & 0.9925 & 0.0004 & 0.9929 & 0.0004 & 0.04 \\
\hline 3 & CR3SP3 & $6.09 \mathrm{E}-01$ & 0.9946 & 0.0005 & 0.9950 & 0.0005 & 0.04 \\
\hline 4 & CR3SP4 & $6.28 \mathrm{E}-01$ & 0.9920 & 0.0004 & 0.9928 & 0.0004 & 0.08 \\
\hline 5 & CR3SP5 & $6.58 \mathrm{E}-01$ & 0.9924 & 0.0004 & 0.9941 & 0.0005 & 0.17 \\
\hline 6 & CR3SP6 & $6.46 \mathrm{E}-01$ & 0.9919 & 0.0004 & 0.9930 & 0.0005 & 0.11 \\
\hline 7 & CR3SP7 & $6.43 \mathrm{E}-01$ & 0.9893 & 0.0005 & 0.9907 & 0.0005 & 0.14 \\
\hline 8 & CR3SP8 & $6.62 \mathrm{E}-01$ & 0.9915 & 0.0004 & 0.9913 & 0.0005 & -0.02 \\
\hline 9 & CR3SP9 & $6.35 \mathrm{E}-01$ & 0.9890 & 0.0004 & 0.9915 & 0.0005 & 0.25 \\
\hline 10 & CR3SP10 & 6.64E-01 & 0.9956 & 0.0004 & 0.9960 & 0.0005 & 0.04 \\
\hline 11 & CR3SP11 & 7.24E-01 & 0.9952 & 0.0004 & 0.9948 & 0.0005 & -0.04 \\
\hline 12 & CR3SP12 & $7.08 \mathrm{E}-01$ & 0.9960 & 0.0004 & 0.9981 & 0.0005 & 0.21 \\
\hline 13 & CR3SP13 & $7.88 \mathrm{E}-01$ & 0.9940 & 0.0004 & 0.9956 & 0.0004 & 0.16 \\
\hline 14 & CR3SP14 & $7.80 \mathrm{E}-01$ & 0.9948 & 0.0004 & 0.9958 & 0.0005 & 0.10 \\
\hline 15 & CR3SP15 & $7.36 \mathrm{E}-01$ & 0.9899 & 0.0003 & 0.9927 & 0.0004 & 0.28 \\
\hline 16 & CR3SP16 & $8.74 \mathrm{E}-01$ & 0.9923 & 0.0004 & 0.9932 & 0.0005 & 0.09 \\
\hline 17 & CR3SP17 & $8.40 \mathrm{E}-01$ & 0.9902 & 0.0003 & 0.9908 & 0.0005 & 0.06 \\
\hline 18 & CR3SP18 & $8.46 \mathrm{E}-01$ & 0.9906 & 0.0003 & 0.9922 & 0.0005 & 0.16 \\
\hline 19 & CR3SP19 & $8.27 \mathrm{E}-01$ & 0.9895 & 0.0004 & 0.9899 & 0.0005 & 0.04 \\
\hline 20 & CR3SP20 & $7.78 \mathrm{E}-01$ & 0.9912 & 0.0005 & 0.9932 & 0.0004 & 0.20 \\
\hline 21 & CR3SP21 & $7.83 \mathrm{E}-01$ & 0.9899 & 0.0003 & 0.9925 & 0.0005 & 0.26 \\
\hline 22 & CR3SP22 & 9.39E-01 & 0.9905 & 0.0004 & 0.9904 & 0.0004 & -0.01 \\
\hline 23 & CR3SP23 & $9.42 \mathrm{E}-01$ & 0.9903 & 0.0004 & 0.9902 & 0.0005 & -0.01 \\
\hline 24 & CR3SP24 & 9.34E-01 & 0.9916 & 0.0004 & 0.9906 & 0.0005 & -0.10 \\
\hline 25 & CR3SP25 & $8.52 \mathrm{E}-01$ & 0.9910 & 0.0005 & 0.9905 & 0.0004 & -0.05 \\
\hline 26 & CR3SP26 & 8.37E-01 & 0.9910 & 0.0005 & 0.9907 & 0.0005 & -0.03 \\
\hline 27 & CR3SP27 & 8.20E-01 & 0.9873 & 0.0004 & 0.9877 & 0.0004 & 0.04 \\
\hline 28 & CR3SP28 & $9.60 \mathrm{E}-01$ & 0.9895 & 0.0004 & 0.9921 & 0.0004 & 0.26 \\
\hline 29 & CR3SP29 & 9.32E-01 & 0.9919 & 0.0004 & 0.9931 & 0.0005 & 0.12 \\
\hline 30 & CR3SP30 & $9.23 \mathrm{E}-01$ & 0.9897 & 0.0004 & 0.9908 & 0.0005 & 0.11 \\
\hline 31 & CR3SP31 & $8.81 \mathrm{E}-01$ & 0.9861 & 0.0004 & 0.9884 & 0.0005 & 0.23 \\
\hline 32 & CR3SP32 & $1.04 \mathrm{E}+00$ & 0.9811 & 0.0005 & 0.9916 & 0.0005 & 1.06 \\
\hline 33 & CR3SP33 & $8.60 \mathrm{E}-01$ & 0.9807 & 0.0005 & 0.9873 & 0.0005 & 0.67 \\
\hline
\end{tabular}

${ }^{a}$ CSAS25 input and output files are available in the DVD attachment, path: DVD/exps/CRC/CrystalRiver/csas.

${ }^{b}$ MCNP criticality calculations for Crystal River Unit 3 are provided in Ref. 61.

${ }^{c} 100 x$ (Comparison calculation $\left.k_{\text {eff }}-\operatorname{CSAS} 25 k_{\text {eff }}\right) /$ Comparison calculation $k_{\text {eff. }}$. 
Figure D-1 shows the distribution histogram plot for PWR and BWR Grand Gulf CRC $k_{\text {eff }}$ values that pass $\chi^{2}$ normality test in /DVD/cl/Table18/case8.xls, worksheet normality test.

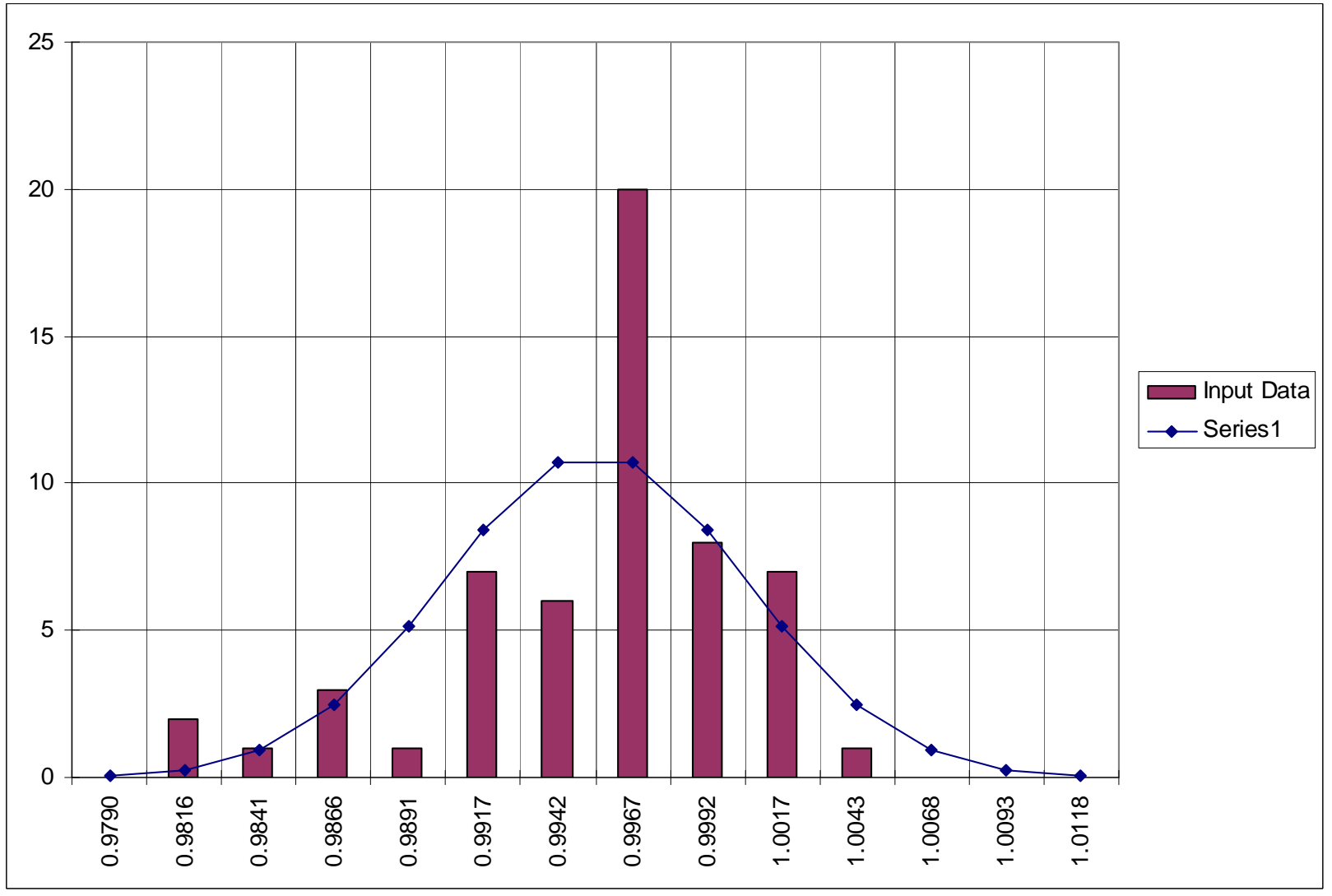

Fig. D-1. CRC $k_{\text {eff }}$ frequency histogram 

APPENDIX E: Statistical Methods for LBTL Determination

E-1 

This appendix describes the equations for applying the lower uniform tolerance band method, the regression fit significance test, and the $\chi^{2}$ normality test.

\section{Lower Uniform Tolerance Band Method}

The $L B T L$ function from the LUTB method is computed as ${ }^{18}$

$$
\operatorname{LBTL}(x)=1.0-\left(C_{\alpha / P} \cdot s_{P}\right)+\beta(x),
$$

where $x$ is a trending parameter, $s_{p}$ is the pooled variance of $k_{\text {eff }}$ values, and $\beta(x)=k_{\text {eff }}(x)-1$. The term $C_{\alpha / P} \cdot s_{P}$ provides a band for which there is a probability $P$ with a confidence $\alpha$ that an additional calculation of $k_{\text {eff }}$ for a critical system will lie within the band. For example, a C95/95 multiplier produces a USL for which there is a $95 \%$ confidence that 950 out of 1000 future calculations of critical systems will yield a value of $k_{\text {eff }}$ above the USL.

The analysis is over the closed interval from $x=a$ to $x=b$ that includes $n$ data points. $C_{\alpha / P}$ is calculated according to the following equations:

$$
\begin{aligned}
& g=\sqrt{\frac{1}{n}+\frac{(a-\bar{x})^{2}}{\sum_{i=1}^{n}\left(x_{i}-\bar{x}\right)^{2}}} \\
& h=\sqrt{\frac{1}{n}+\frac{(b-\bar{x})^{2}}{\sum_{i=1}^{n}\left(x_{i}-\bar{x}\right)^{2}}} \\
& \rho=\frac{1}{g h} \cdot\left\{\frac{1}{n}+\frac{(a-\bar{x})(b-\bar{x})}{\sum_{i=1}^{n}\left(x_{i}-\bar{x}\right)^{2}}\right\} \\
& A=\frac{g}{h}
\end{aligned}
$$

$A, \rho$, and $(n-2)$ are used to determine the value of $D$ (refer to Eq. E-1) from Table 3 in Ref. 19, which covers values of $0.5 \leq A \leq 1.5$. The procedure to follow when $\mathrm{A}$ is in this range is

$$
C^{*}=D \cdot A g
$$

When $A$ is outside the above range, $A$ is replaced by $1 / A$ for the determination of $D$, and $C^{*}$ is given by

$$
C^{*}=D \cdot A h
$$

Next, 


$$
C_{\alpha / P}=C^{*}+z_{P} \cdot \sqrt{\frac{n-2}{\chi^{2}}},
$$

where

$z_{P}$ is the Student $t$ statistic depending on $n$ and $P$, and

$\chi^{2}$ is the chi square distribution, a function of $(n-2)$ and $\alpha$.

Parameter $\mathrm{D}$ is the solution to the following equation:

$$
\int_{-D-A D}^{D} \int_{A}^{A D} \frac{1}{2 \pi\left(1-\rho^{2}\right)^{1 / 2}}\left[1+\frac{u^{2}-2 p u w+v^{2}}{(n-2)\left(1-\rho^{2}\right)}\right]^{-n / 2} d u d v=1-\gamma,
$$

where $1-\gamma$ is the confidence coefficient.

The pooled standard deviation is obtained from the pooled variance $\left(s_{p}=\sqrt{s_{p}^{2}}\right)$, where $s_{p}^{2}$ is given as

$$
s_{p}^{2}=s_{k(x)}^{2}+s_{w}^{2},
$$

where $s_{k(x)}^{2}$ is the variance (or mean-square error) of the regression fit, and is given by:

$$
s_{k(x)}^{2}=\frac{1}{(n-2)}\left[\sum_{i=1, n}\left(k_{i}-\bar{k}\right)^{2} \frac{\left\{\sum_{i=1, n}\left(x_{i}-\bar{x}\right)\left(k_{i}-\bar{k}\right)\right\}^{2}}{\sum_{i=1, n}\left(x_{i}-\bar{x}\right)^{2}}\right] \text {, }
$$

and $s_{w}^{2}$ is the within-variance of the data:

$$
s_{w}^{2}=\frac{1}{n} \sum_{i=1, n} \sigma_{i}^{2}
$$

where $\sigma_{i}$ is the standard deviation associated with $k_{i}$ for a Monte Carlo calculation. For best results, it is recommended that the individual standard deviations for the Monte Carlo calculations be roughly uniform in value. For deterministic codes that do not have a standard deviation associated with a computed value of $k$, the standard deviation is zero. However, this term could be used as a mechanism to include known uncertainties in experimental data.

\section{Statistical Significance of Trending}

For the linear regression models, statistical significance of trending is determined by the test of hypothesis that the slope differs from zero, as described in Ref. 77. The statistical model is a linear relationship between an independent variable predictor variable, $x$ (e.g., EALF, burnup, etc.) and the dependent variable, $y(x)$ (e.g., LBTL):

$$
y(x)=\beta_{0}+\beta_{1} x+\varepsilon
$$


where, $\varepsilon$ is a random variable possessing a specified probability distribution with mean zero so that the expected value for $f(x)$ is $E(Y)=\beta_{0}+\beta_{1} x$. Inferences concerning the parameter $\beta_{1}$ can be obtained using the following test statistic that possesses a Student's distribution with $n$ - 2 degrees of freedom, where $n$ is the sample size:

$$
T=\frac{\hat{\beta}_{1}-\beta_{10}}{S \sqrt{c_{11}}},
$$

where

$\hat{\beta}_{1}=\frac{S_{x y}}{S_{x x}}$ is an unbiased, normally distributed estimator of $\beta_{1}$,

$\beta_{10}$ is a specified value of $\beta_{1}$, which is zero in the case of null hypothesis testing,

$S^{2}=S S E /(n-2)$,

$S S E=S_{y y}-\hat{\beta}_{1} S_{x y}$,

$c_{11}=\frac{1}{S_{x x}}$,

$S_{x x}=\sum_{i=1}^{n}\left(x_{i}-\bar{x}\right)^{2}$,

$S_{x y}=\sum_{i=1}^{n}\left(x_{i}-\bar{x}\right)\left(y_{i}-\bar{y}\right)$, and

$\bar{x}=\frac{1}{n} \sum_{i=1}^{n} x_{i}$

The Test of Hypothesis for $\beta_{1}$ is

$$
\begin{array}{ll}
\mathrm{H}_{0}: & \beta_{1}=0 \\
\mathrm{H}_{\mathrm{a}}: & \beta_{1} \neq 0 \text { (two-tailed rejection region) } \\
\text { Test Statistic: } & T=\frac{\hat{\beta}_{1}-\beta_{10}}{S \sqrt{c_{11}}} \\
\text { Rejection Region: } & |t|>t_{\alpha / 2} \text { (two-tailed alternative), where } \alpha \text { is the level of significance. }
\end{array}
$$

\section{$\underline{\text { Chi2 Normality Test }}$}

The $\chi^{2}$ normality test is applied to binned $k_{\text {eff }}$ values using the following statistic ${ }^{76}$

$$
\chi^{2}=\sum_{i=1}^{k}\left(n_{i}^{2} / n P_{i}\right)-n
$$

where $k$ is the number of bins, $n_{i}$ is the number of $k_{\text {eff }}$ values in each bin, $n P_{i}$ is the expected number of $k_{e f f}$ values in each bin, and $n$ is the sample size.

The Test of Hypothesis for the normality test is:

$\mathrm{H}_{0}$ : $\quad$ The $k_{\text {eff }}$ values follow a normal distribution

$\mathrm{H}_{\mathrm{a}}$ : $\quad$ The $k_{\text {eff }}$ values do not follow a normal distribution

Rejection: $\quad \chi^{2} \geq \chi_{1-\alpha}^{2}$ for $k-1$ degrees of freedom, where $\alpha$ is the significance level. 


\section{APPENDIX E REFERENCE}

77. D. D. Wackerly, W. Mendenhall III, and R. L. Scheaffer, Mathematical Statistics with Applications, 5th Edition, Belmont, CA, Wadsworth Publishing Company, 1996. 
APPENDIX F: Electronic Data Specifications

F-1 

This appendix contains a listing and description of files contained in the Digital Versatile/Video Discs (DVD+R format) that are attached to the calculation report Range of Applicability and Bias

Determination for Postclosure Criticality of Commercial Spent Nuclear Fuel. The operating system used to create the electronic data on the DVDs was Microsoft Windows Vista Enterprise, Version 6.0.6000 Build 6000. The files stored on the electronic media consist of MCNP or SCALE input and output files (text format), Microsoft Excel files, and a Mathematica file. The following process controls for storage and protection of electronic data apply.

Medium: $\quad$ DVD

Conditions: $\quad$ Fireproof cabinet kept at ambient temperature

Location: $\quad$ OCRWM QA Records, currently stored in Building 5700, Room H330

Retention Time: $\quad$ Lifetime

Security: $\quad$ Fireproof cabinet is locked

Access: $\quad$ Project manager and records custodian only

The electronic data for the calculation is provided on seven DVDs and the folder contents are listed below. Hierarchical directory structure and name, size, date, and time for each electronic file are listed in the text file overall_listing included in DVD-7.

Table F-1. DVD content summary

\begin{tabular}{|c|c|c|c|c|c|}
\hline DVD no. & Folder/file name & Size & $\begin{array}{c}\text { Number } \\
\text { of files }\end{array}$ & File time $^{b}$ & Description \\
\hline DVD-1 & DVD/exps/CRC/CrystalRiver/csas/ & $4.33 \mathrm{~GB}$ & 36 & 7:27:25 a.m. & $\begin{array}{l}\text { Crystal River, state-points } 1 \\
\text { through } 18, \text { CSAS25 files }\end{array}$ \\
\hline DVD-2 & DVD/exps/CRC/CrystalRiver/csas/ & $4.12 \mathrm{~GB}$ & 30 & 8:04:12 a.m. & $\begin{array}{l}\text { Crystal River, state-points } 19 \\
\text { through 33, CSAS25 files }\end{array}$ \\
\hline \multirow[t]{3}{*}{ DVD-3 } & DVD/exps/CRC/CrystalRiver/mcnp/ & $832 \mathrm{MB}$ & 96 & 8:31:06 a.m. & Crystal River, MCNP files \\
\hline & $\begin{array}{l}\text { DVD/exps/CRC/CrystalRiver/sens- } \\
\text { unqualified/ }\end{array}$ & $244 \mathrm{MB}$ & 94 & 8:35:36 a.m. & $\begin{array}{l}\text { Crystal River, TSUNAMI } \\
\text { sensitivity files }\end{array}$ \\
\hline & DVD/exps/CRC/GrandGulf/mcnp/ & $1.77 \mathrm{~GB}$ & 6 & 8:36:55 a.m. & $\begin{array}{l}\text { Grand Gulf, state-points } 5,6 \& \\
7, \text { MCNP files }\end{array}$ \\
\hline DVD-4 & DVD/exps/CRC/GrandGulf/mcnp/ & $4.31 \mathrm{~GB}$ & 14 & 8:49:31 a.m. & $\begin{array}{l}\text { Grand Gulf, state-points } 10 \\
\text { through } 16, \text { MCNP files }\end{array}$ \\
\hline DVD-5 & DVD/exps/CRC/GrandGulf/mcnp/ & $3.82 \mathrm{~GB}$ & 12 & 9:15:32 a.m. & $\begin{array}{l}\text { Grand Gulf, state-points } 18 \\
\text { through 23, MCNP files }\end{array}$ \\
\hline \multirow[t]{10}{*}{ DVD-6 } & DVD/exps/CRC/McGuire/ & $842 \mathrm{MB}$ & 13 & 10:29:17 a.m. & MCNP files for McGuire CRCs \\
\hline & DVD/exps/CRC/Sequoyah/ & $46.6 \mathrm{MB}$ & 6 & 10:33:49 a.m. & $\begin{array}{l}\text { MCNP files for Sequoyah } \\
\text { CRCs }\end{array}$ \\
\hline & DVD/exps/CRC/TMI/ & $43.5 \mathrm{MB}$ & 6 & 10:34:04 a.m. & MCNP files for TMI CRCs \\
\hline & DVD/exps/leu/ & $168 \mathrm{MB}$ & 186 & 10:34:18 a.m. & $\begin{array}{l}\text { MCNP and TSUNAMI-3D files } \\
\text { for LEU LCEs }\end{array}$ \\
\hline & DVD/exps/mox/ & $2.17 \mathrm{~GB}$ & 2,175 & 10:35:15 a.m. & $\begin{array}{l}\text { MCNP and TSUNAMI-3D files } \\
\text { for MOX LCEs }\end{array}$ \\
\hline & DVD/apps/ & $472 \mathrm{MB}$ & 6,872 & 10:15:43 a.m. & $\begin{array}{l}\text { MCNP, CSAS25, and } \\
\text { TSUNAMI-3D files for waste } \\
\text { packages }\end{array}$ \\
\hline & $\mathrm{DVD} / \mathrm{dp}$ & $439 \mathrm{MB}$ & 299 & 10:26:44 a.m. & $\begin{array}{l}\text { MCNP files for direct } \\
\text { perturbation calculations }\end{array}$ \\
\hline & $\mathrm{DVD} / \mathrm{cl}$ & $12.5 \mathrm{MB}$ & 21 & 10:26:39 a.m. & Excel and Mathematica files \\
\hline & LoadingCurve_v344.xls & $7.96 \mathrm{MB}$ & 1 & 10:15:35 a.m. & Calculation output file \\
\hline & Tables.xls & $903 \mathrm{~KB}$ & 1 & 10:15:43 a.m. & Summary results Excel file \\
\hline
\end{tabular}


Table F-1. DVD content summary (continued)

\begin{tabular}{|c|c|c|c|c|c|}
\hline $\begin{array}{l}\text { DVD } \\
\text { no. }\end{array}$ & Folder/file name & Size & $\begin{array}{l}\text { Number } \\
\text { of files }\end{array}$ & File time $^{b}$ & Description \\
\hline \multirow[t]{12}{*}{ DVD-7 } & $\mathrm{DVD} / \mathrm{exps} / \mathrm{htc} /{ }^{a}$ & $1.54 \mathrm{~GB}$ & 791 & 10:57:46 a.m. & $\begin{array}{l}\text { MCNP and TSUNAMI-3D files } \\
\text { for HTC LCEs }\end{array}$ \\
\hline & DVD/ip/ & $1.69 \mathrm{~GB}$ & 25,182 & 11:07:04 a.m. & TSUNAMI-IP files \\
\hline & separate DVD trees.out & $8.68 \mathrm{~KB}$ & 1 & 11:48:25 a.m. & Separate DVD trees \\
\hline & DVDtree.out & $5.95 \mathrm{~KB}$ & 1 & 11:48:24 a.m. & DVD tree \\
\hline & overall_listing & $2.63 \mathrm{MB}$ & 1 & 11:48:24 a.m. & $\begin{array}{l}\text { File name, size, date, and time } \\
\text { for all files }\end{array}$ \\
\hline & DVD-1_listing & $2.86 \mathrm{~KB}$ & 1 & 11:48:23 a.m. & $\begin{array}{l}\text { File name, size, date, and time } \\
\text { for all files on DVD-1 }\end{array}$ \\
\hline & DVD-2_listing & $2.47 \mathrm{~KB}$ & 1 & 11:48:23 a.m. & $\begin{array}{l}\text { File name, size, date, and time } \\
\text { for all files on DVD-2 }\end{array}$ \\
\hline & DVD-3_listing & $13.1 \mathrm{~KB}$ & 1 & 11:48:23 a.m. & $\begin{array}{l}\text { File name, size, date, and time } \\
\text { for all files on DVD-3 }\end{array}$ \\
\hline & DVD-4_listing & $1.30 \mathrm{~KB}$ & 1 & 11:48:23 a.m. & $\begin{array}{l}\text { File name, size, date, and time } \\
\text { for all files on DVD-4 }\end{array}$ \\
\hline & DVD-5_listing & $1.24 \mathrm{~KB}$ & 1 & 11:48:23 a.m. & $\begin{array}{l}\text { File name, size, date, and time } \\
\text { for all files on DVD-5 }\end{array}$ \\
\hline & DVD-6_listing & $694 \mathrm{~KB}$ & 1 & 11:48:23 a.m. & $\begin{array}{l}\text { File name, size, date, and time } \\
\text { for all files on DVD-6 }\end{array}$ \\
\hline & DVD-7_listing & $1.94 \mathrm{MB}$ & 1 & 11:48:23 a.m. & $\begin{array}{l}\text { File name, size, date, and time } \\
\text { for all files on DVD-7 }\end{array}$ \\
\hline
\end{tabular}

${ }^{a}$ Limited Rights Data (French HTC Experimental Data).

${ }^{b}$ All DVDs were created on October 9, 2007 by D. E. Mueller. 
ORNL/TM-2007/127

\section{EXTERNAL DISTRIBUTION}

1. C. Howard, Sandia National Laboratory, 1180 Town Center Drive, Las Vegas, NV 89144

2. J. M. Scaglione, Sandia National Laboratory, 1180 Town Center Drive, Las Vegas, NV 89144 